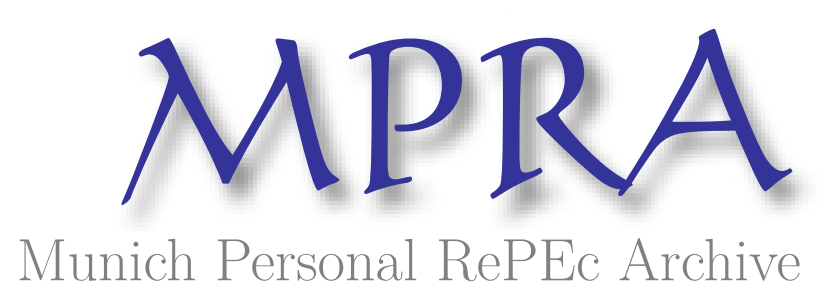

\title{
EUROMON: The multi-country model of De Nederlandsche Bank
}

Demertzis, Maria and Van Els, Peter and Grob, Sybille and Peeters, Marga

De Nederlandsche Bank

2006

Online at https://mpra.ub.uni-muenchen.de/28512/

MPRA Paper No. 28512, posted 01 Feb 2011 19:33 UTC 


\section{Occasional Studies}

EUROMON: the multi-country model of De Nederlandsche Bank 


\section{Occasional Studies}

Vol.4/Nr.I (2006)

Maria Demertzis, Peter van Els, Sybille Grob and Marga Peeters

EUROMON: the multi-country model of De Nederlandsche Bank 


\section{(C)2006 De Nederlandsche Bank NV}

Corresponding authors: Maria Demertzis, Peter van Els and Sybille Grob e-mail: m.demertzis@dnb.nl, p.j.a.van.els@dnb.nl and s.g.grob@dnb.nl.

Aim of Occasional Studies is to disseminate thinking on policy and analytical issues in areas relevant to the Bank.

Views expressed are those of the individual authors and do not necessarily reflect official positions of De Nederlandsche Bank.

Editorial Committee

Lex Hoogduin (chairman), Eelco van den Berg (secretary), Hans Brits, Maria Demertzis, Maarten Gelderman, Klaas Knot, Bram Scholten, Job Swank.

All rights reserved. No part of this publication may be reproduced, stored in a retrieval system, or transmitted in any form by any means, electronic, mechanical, photocopy, recording or otherwise, without the prior written permission of the Nederlandsche Bank.

Subscription orders for DNB Occasional Studies and requests for specimen copies should be sent to:

De Nederlandsche Bank NV

Communications

P.o. Box 98

Iooo AB Amsterdam

The Netherlands

Internet: www.dnb.nl 


\title{
EUROMON: the multi-country model of
}

\section{De Nederlandsche Bank}

\author{
Maria Demertzis*, Peter van Els*, Sybille Grob* and Marga Peeters**
}

\begin{abstract}
This Occasional Study wraps up the modelling work that has been done in recent years regarding DNB's multi-country model EUROMON. It offers a description of the current version of the model and provides information about its simulation properties through the analysis of variety of standard scenarios. EUROMON is an estimated multi-country model. The current version includes 13 individual country models plus a trade block providing the international linkages between these countries. The 13 countries are the EMU-participants Germany, France, Italy, Spain, the Netherlands, Belgium, Austria and Finland, the EU-countries of the United Kingdom, Sweden and Denmark, plus the United States and Japan. The country models all share the same basic structure. Differences mainly relate to distinct values of model parameters and speeds of adjustment, and in some cases to slightly different specifications of equations in order to allow for specific institutional features of individual countries. EUROMON is a neo-Keynesian model in spirit, combining a vertical supply curve in the long run with an important role for demand factors in the short-run determination of output. The model incorporates a wage bargaining framework which makes the long-run supply curve dependent on real factors, such as tax policies. EUROMON is an aggregate model, with no further breakdown in sectors or categories of goods and services. The current version of the model is backward-looking. The study concludes by addressing the main shortcomings and strong features of the model that require further attention.
\end{abstract}

JEL-codes: C5, E17

Key words: structural macroeconomic modelling, model simulation, scenario analysis

* Research Division, De Nederlandsche Bank, P.O. Box 98, 1000 AB Amsterdam.

** Banka e Shqipërisë, IMF Monetary Policy Advisor

\section{Acknowledgements}

We thank Rob Vet, Peter Keus, Menno Grevelink and Claudia Kerkhoff for statistical and research assistance during the various stages of the development of EUROMON. The authors acknowledge the comments by participants in the CEPR/ZEI Comparison of Macro models Workshop in Bonn on 7-8 June, 2002 and by members of the ESCB's Working Group on Econometric Modelling. 



\section{Table of Contents}

1 Introduction

2 A bird's eye view of EUROMON

2.1 Aggregate supply

$2.2 \quad$ Aggregate demand 14

$\begin{array}{lll}2.3 & \text { Prices and costs } & 20\end{array}$

$2.4 \quad$ Government sector 25

$2.5 \quad$ Monetary and financial sector 26

$3 \quad$ Model properties $\quad 35$

$\begin{array}{lll}3.1 & \text { Simulation design and policy rules } & 37\end{array}$

$\begin{array}{lll}3.2 & \text { Simulation results } & 39\end{array}$

3.2.1 Reduction in the policy-controlled interest rate by 1 percentage point over 8 quarters 40

3.2.2 Worldwide reduction in capital market rates by 1 percentage point over 8 quarters 42

3.2.3 Permanent appreciation of the effective exchange rate of the US dollar by 10\% 43

3.2.4 Permanent appreciation of the effective exchange rate of the euro by 10\% 43

3.2.5 Permanent increase in the non-wage government consumption by $1 \%$ of GDP 43

3.2.6 Permanent ex ante balanced-budget reduction in income taxes by $1 \%$ of GDP in the euro area (accompanied by a reduction in non-wage government consumption) 45

3.2.7 Permanent increase in the indirect taxation in the euro area equal to 1\% GDP 45

3.2.8 Increase in oil prices by $25 \%$ over 8 quarters 46

3.2.9 Reduction in domestic spending in the US, the UK and Japan over 8 quarters 46

3.2.10 Autonomous increase in inflation in the euro area by 1 percentage point over 4 quarters $\quad 47$

3.2.11 Reduction in house prices by $10 \%$ over 8 quarters 47

3.2.12 Worldwide fall in share prices by $25 \%$ over 8 quarters 48

3.2.13 Autonomous increase in the wage level by $1 \%$ over 4 quarters 49

3.2.14 Permanent reduction in the supply of labour in the euro area by $1 \% \quad 50$

$\begin{array}{ll}\text { Tables with simulation results } & 51\end{array}$

$4 \quad$ Epilogue $\quad 94$

$\begin{array}{ll}\text { References } & 95\end{array}$ 
Annex Behavioural equations and a stylized presentation of EUROMON

A Behavioural equations

B A stylized presentation of EUROMON

Publications in this series as from January 2003 
1 Introduction

EUROMON is De Nederlandsche Bank's (DNB) macroeconometric multi-country model which was developed in the 1990s. EUROMON has in the past been used for forecasting as well as conducting policy and scenario analyses and counterfactual simulation exercises. In the period between 1996 and 1998, EUROMON projections were published biannually in the DNB's Quarterly Bulletin, reflecting a combination of model-based and judgmental information. Judgmental sources included available non-model information taken from new releases of cyclical and price indicators or from predictions based on other in-house or outside models. With the start of EMU in 1999 however, DNB has stopped publishing euro area projections, shifting the emphasis of the model's uses towards topical policy and scenario analyses. The results of these analyses have been regularly reported in the Quarterly Bulletin. While being an important contributor to policy preparation, EUROMON underwent changes that made it more suitable to its two main subsequent uses, policy analysis and research. Most of these changes, which included a re-specification and re-estimation of many of the model's equations partly in view of the advent of EMU but also in order to strengthen the long-run simulation properties, have been implemented in 2001 and 2002, while in subsequent years the model's simulation properties have been further tested and documented. This Occasional Study wraps up the work that has been done. The present version of the model builds on the version documented in De Nederlandsche Bank (2000). For a comparison of EUROMON with other central bank models, the reader is referred to Fagan and Morgan (2005, forthcoming).

EUROMON is an estimated quarterly multi-country model. The current version includes 13 individual country blocks plus a trade block that provides for international linkages. The 13 countries included are most EMU-participants - Germany, France, Italy, Spain, Netherlands, Belgium, Austria and Finland, three EU-countries - United Kingdom, Sweden and Denmark, and finally the United States and Japan. The uses of the model (previously but also currently) necessitated an attempt to capture as many country differences as possible, beyond the country size. These are essential in the policy realm because they 1) enhance our understanding of the euro area as a whole, 2) help us analyse the role of spillovers between the euro area and the other large countries/regions in the world economy and, 3) provide an understanding of the ways that countries in the euro area differ. In these respects, EUROMON offers a richer structure than models focusing on the aggregate euro area only, such as the ECB's Area Wide Model by Fagan, Henry and Mestre (2005). In EUROMON country models share the same basic structure but have distinct values of model parameters and speeds of adjustment. In a few cases slightly different specifications of equations are allowed as well, in order to deal with country specific 
institutional features. The long-run properties of the model are for the moment derived only theoretically and we have not examined the long-run simulation properties beyond their stability in the medium run. In terms of theoretical underpinnings, the model is in general terms neoKeynesian, combining a vertical supply curve in the long-run with an important role for demand factors in what determines output in the short-run. The model encompasses a wage bargaining framework which renders the long-run supply curve dependent on real factors, such as tax policies. EUROMON is an aggregate model, with no further breakdown in sectors or categories of goods and services. Country models consist of 25 behavioural equations and 50 identities. In addition we model a number of world variables as well as area wide aggregates.

The remainder of the study is organised as follows. Chapter 2 looks closely at the theoretical properties of the model, describing both the underlying structures assumed as well as possible deviations from the theory justified by our desire to capture short term dynamics. This section incorporates a detailed description of the equations used as well as the main economic intuition underlying them. In addition we present the long-term impact multipliers for each of the countries included and for each behavioural equation separately. Chapter 3 then reports a number of indicative simulations to identify the properties of the model. Chapter 4 concludes by briefly addressing the main shortcomings and stronger aspects of the current model version that require further attention. Finally, Annex A includes the estimates of all behavioural equations and Annex $B$ gives a stylised representation of the economy. 


\section{A bird's eye view of EUROMON}

\section{General features}

EUROMON is a backward looking model. Expectations are thus treated implicitly, through the inclusion of lags (adaptive expectations). The rationale behind this choice was that the model was originally built to help provide short term forecasts for the main macroeconomic variables of the individual countries and the aggregate euro area. It was important, therefore, to consider macroeconomic series that were able to track the history of the variables as closely as possible. Typicaily, this is best done when considering autoregressive series. With the adoption of the single currency however, the process of macroeconomic forecasting is centralised at the European Central Bank and there is no urgent need to provide alternative macroeconomic forecasts for the euro area. EUROMON therefore now faces fewer restrictions in helping evaluate policy analysis. To this end, we concentrate more and more on the internal theoretical consistency of the model and less on its ability to provide accurate short-term forecasts.

\section{Specification}

EUROMON has some 1000 equations in total, 330 of which are estimated. The estimation period starts in 1970 (if data are available) and ends in 1999. We have applied Ordinary Least Squares in most cases, to estimate single equation systems. Detailed information on individual equations and parameters can be found in Annex A. The model is constructed with the notion of equilibrium in mind. In other words, the long-run relationship representing static economic theory between the variables in each equation takes the following form:

$$
Y_{t}=c_{o}+\sum_{i=1}^{m} c_{i} X_{i, t}
$$

where $Y_{t}$ stands for the endogenous variable at time $\mathrm{t}$ in the equation and $X_{i, t}$ for the explanatory variables at time $\mathrm{t}$, and $c_{i}$ for the parameters governing the long-run relationship. Since the state of variables at any point in time does not necessarily reflect the state of equilibrium, we embed all equilibrium conditions in a dynamic Error Correction framework and estimate the law of motion towards their equilibrium paths, in the following way.

$$
\Delta Y_{t}=c+\gamma\left(Y_{i-1}-\sum_{i=1}^{m} c_{i} X_{i, t-1}\right)+\alpha(L) \Delta Y_{t-1}+\sum_{i=1}^{m} \beta_{i}(L) \Delta X_{i, t-1}
$$


Here, $c$ is the intercept and $\gamma$ the error-correction coefficient that together with the parameters $\alpha(L)$ and $\beta_{i}(L)$ determine the dynamics of equilibrium adjustment, with $L$ reflecting the lag operator. Using this framework the data is allowed to determine the significant timing of the series.

\subsection{Aggregate supply}

Summary. Aggregate supply is given by a CES production technology, with two inputs: capital and labour. In the long-run, output of firms is determined by the supply of labour largely exogenous), the equilibrium unemployment rate (captured by the NAWRU) and technical progress, which is measured by the development of total factor productivity. Equations for labour demand and the non-residential capital stock are derived from first-order conditions. Labour demand depends on output and real product wages. Non-residential private investment depends on the real user cost of capital and the capital-output ratio, in line with the CES production technology. The dynamics of investment are also affected by short-run changes in total sales and profitability.

\section{Labour demand and capital stock}

We assume a CES-production function for the non-government sector: ${ }^{1}$

$$
y_{b, l}=A e^{\eta l+\varepsilon_{y, l}}\left[(1-\delta) k_{b, t-1}^{-\rho}+\delta l h_{b, l}^{-\rho}\right]^{-\frac{1}{\rho}}, \quad \rho>-1, \quad 0<\delta<1
$$

where

$$
\begin{array}{ll}
A e^{\eta 1+\varepsilon_{y}} & =\text { total factor productivity } \\
y_{b} & =\text { business production in real terms, value added at factor costs } \\
k_{b} & =\text { business capital stock (excluding dwellings) in real terms } \\
l h_{b} & =\text { business employment (in labour hours) } \\
\eta & =\text { parameter measuring autonomous rate of technical progress } \\
\delta & =\text { distribution parameter } \\
\rho & =\text { substitution parameter }
\end{array}
$$

\footnotetext{
${ }^{1}$ The choice of a CES rather than Cobb-Douglas production function is based on the empirical finding that the real product wage elasticity of labour demand lies between 0 and -1 and may differ between countries.
} 
$\mathrm{t} \quad=$ deterministic linear trend

$\varepsilon_{y} \quad=$ technology shock, also known as the Solow-residual.

The distribution parameter $\delta$ measures the degree to which the production technology is labour intensive. Based on conventional terminology, output $y_{h, t}$ can be divided into an explained part $f\left(k_{b, t-1}, l h_{h, l}\right)$ and an unexplained part $A e^{\eta t+\varepsilon_{y, t}}$, identified with total factor productivity. Under profit maximisation, the marginal products of labour and capital move in line with output and real factor prices. First-order conditions provide the long-run specification of the relationships for labour demand and the non-residential capital stock, respectively:

$$
\begin{aligned}
& \log l h_{b, t}=\beta_{l}+\log y_{b, t}+\sigma\left(\log w h_{b, t}-\log p_{v b, t}\right)-(1+\sigma) \eta t \\
& \log k_{b, t-1}=\beta_{k}+\log y_{b, t}+\sigma \log u c c_{l}-(1+\sigma) \eta t
\end{aligned}
$$

with $\beta_{i}$ and $\beta_{k}$ constants, $\sigma=-1 /(1+\rho)$ and

$$
\begin{array}{ll}
w h_{b} & =\text { non-government wage rate (per hour) } \\
p_{y h} & =\text { price deflator value added at factor costs (index, 1990=100) } \\
u c c & =\text { user cost of capital in real terms } \\
t & =\text { deterministic linear trend. }
\end{array}
$$

Hence, the logarithms of the labour-output and capital-output ratios depend linearly on the relative factor costs and a time trend. The real capital stock adjusts to its 'steady state level' in the long run, determining the dynamics of non-residential investment. The user cost of capital in real terms $u c c$, is defined at a quarterly basis as:

$$
u c c_{1}=\frac{1}{800}\left(r_{l, t}+r_{s, t}\right)-\frac{1}{400} \dot{p}_{y h, t}+\underline{\kappa}_{h}+\underline{u c c c_{l}^{r i v k}}
$$

comprising of a real interest rate, calculated as a weighted average of the long- and short-term interest rate. Furthermore, we incorporate both the physical capital depreciation rate $\underline{\kappa}_{h}$, as well as a risk premium $u c c_{t}^{\text {risk }} .{ }^{2}$ The non-residential capital stock evolves according to:

\footnotetext{
2 The risk premium is calibrated to ensure that it equals $\left(1-\gamma_{w i}\right) \frac{y_{b, t}}{k_{\mathrm{b}, t}}-\frac{1}{800}\left(r_{t, t}+r_{s, t}\right)+\frac{1}{400} \dot{p}_{y, h, t}-\underline{\kappa}_{b}$ on average, over the sample period, where $\gamma_{i r}$ denotes the average wage share over this sample period. This
} 
$k_{h, t}=i_{h}+\left(1-\underline{\kappa}_{h}\right) k_{h, t-1}$

where

$k_{h} \quad=$ business capital stock (excluding dwellings) in real terms

$i_{b} \quad=$ business investment in real terms

$\underline{\kappa}_{h} \quad=$ business capital stock depreciation rate.

The estimated dynamic model equations for labour demand and firms' non-residential investment contain the first-order conditions from the optimisation procedure as error-correction terms. Estimating the labour demand equation provides values for the long-term parameters $\sigma$ and $\eta$.

Table 2.1 Long-term parameter estimates of the business employment and investment equations

\begin{tabular}{|c|c|c|c|c|c|c|c|c|c|c|c|c|c|}
\hline & $\mathrm{AU}$ & $\mathrm{BE}$ & $\mathrm{DE}$ & DK & $\mathrm{ES}$ & $\mathrm{Fl}$ & FR & IT & NL & SW & UK & $J P$ & US \\
\hline$\sigma$ & -0.41 & -0.87 & -0.31 & -1.00 & -1.00 & -0.20 & -0.68 & -0.51 & -0.31 & -0.44 & -0.58 & -1.00 & -0.62 \\
\hline$\eta$ & 0.008 & 0.008 & 0.006 & & & 0.009 & 0.006 & 0.008 & 0.004 & 0.006 & 0.003 & & 0.004 \\
\hline
\end{tabular}

Table 2.1 summarizes the estimated coefficients. We calibrate $\sigma$, the product wage elasticity, to equal 1 in Denmark, Spain and Japan. For these countries the production function is therefore of the Cobb-Douglas form. The coefficients derived from estimating the labour demand equations, denoted $\hat{\sigma}$ and $\hat{\eta}$, are implemented when estimating the investment equations. Beyond these however, we also include several other factors that have empirically been proven to affect investment in the short run. First, we include lagged changes in investment to allow for persistence in the investment process. Second, we include changes in real sales, $s_{1}$, in order to capture possible accelerator effects. Third, changes in the output gap are included to capture potential business cycle effects. Fourth, the existence of any liquidity constraints is taken into account by including a measure of the liquidity position of firms, calculated as changes in the (real) net cash flow. Last, we include the change in the real interest rate to capture the short run influence of changes in the cost of borrowing.

condition corresponds to the marginal productivity condition in the Cobb-Douglas case and therefore serves only as a first approximation of the premium. 
Potential output, labour supply and output gap

To determine potential output and hence the output gap, we define the stock of potential capital $k_{b, l}^{*}$ and potential business employment $l h_{b, t}^{*}$ as follows. First, $k_{b, t}^{*}=k_{b, l}$ on the grounds that the actual series does not fluctuate much by itself. Potential employment in the non-government sector is calculated on the basis of the NAWRU, the unemployment rate level consistent with constant nominal wage inflation. ${ }^{3}$ We implemented the procedure described in Bolt and van Els (2000) which is based on the Elmeskov (1993) method applied at the OECD to construct a timevarying NAWRU. Potential employment is thus calculated as:

$l h_{h, t}^{*}=\underline{\psi}_{t} l_{s, t}\left(1-\underline{u}_{t}^{N}\right)-\underline{\psi}_{l} \underline{x, l}_{h, t}$

where

$$
\begin{array}{ll}
l h_{b}^{*} & =\text { potential business employment (in labour hours) } \\
\underline{\Psi}_{t} & =\text { annual hours worked per person (in thousands per year) } \\
l_{\mathrm{s}} & =\text { total labour force (in persons) } \\
\underline{u}^{N} & =\text { NAWRU; non-accelerating wage rate of unemployment (in \%) } \\
\underline{l}_{x} & =\text { government employment (in persons). }
\end{array}
$$

As equation (6) demonstrates, a lower (higher) natural rate of unemployment leads to higher (lower) potential business employment for a given labour supply. Furthermore, potential employment increases with labour supply. For a given labour supply, a shift from employment in the government sector to the business sector also increases potential employment in businesses. In the current version of EUROMON, labour supply is largely exogenous and is assumed to grow at a constant rate over time. For specific simulation experiments, however, labour supply can be made to be influenced by real disposable income and discouraged or encouraged worker effects.

Potential output (business production) is given by:

$$
\log y_{h, t}^{*}=-\frac{1}{\hat{\rho}} \log \left[(1-\hat{\delta})\left(\tilde{k}_{h, t-1}^{*}\right)^{-\hat{\rho}}+\hat{\delta}\left(\widetilde{I h}_{h, l}^{*}\right)^{-\hat{\rho}}\right]+t f p_{t}^{*}
$$

\footnotetext{
${ }^{3}$ Torres and Martin (1990) prove that by applying the NAWRU concept in the definition of potential output, there is equilibrium consistency in the labour and goods market.
} 
where $t f p_{t}{ }^{*}$ is calculated as the HP-trend of the logarithm of actual total factor productivity. The distribution parameter $\delta$ is not invariant to units of measurement. To overcome this, we convert the factor inputs to indices, by dividing them by their sample means when measuring potential output and trend total factor productivity. They are denoted $\tilde{k}_{b, l}$ and $\widetilde{h}_{b, i}$. Parameter $\delta$ was approximated by the value of the average wage share in total production during the sample period, denoted $\hat{\delta}$. The estimated parameter $\hat{\rho}=(-1-\hat{\sigma}) / \hat{\sigma}$, with $\hat{\sigma}$ taken from the labour demand equation, then provides for the values for substitution parameter. Table 2.2 summarises the calibrated distribution and substitution parameters.

Table 2.2 Key parameters of the potential output equations

\begin{tabular}{|c|c|c|c|c|c|c|c|c|c|c|c|c|c|}
\hline & $\mathrm{AU}$ & $\mathrm{BE}$ & $\mathrm{DE}$ & DK & ES & FI & FR & IT & NL & SW & UK & $\mathrm{JP}$ & US \\
\hline$\delta$ & 0.54 & 0.53 & 0.56 & 0.54 & 0.44 & $0.5 \mathbf{I}$ & 0.53 & 0.41 & 0.52 & 0.57 & 0.59 & 0.57 & 0.57 \\
\hline$\rho$ & 1.42 & 0.15 & 2.23 & 0 & 0 & 4.06 & 0.47 & 0.96 & 2.21 & 1.29 & 0.74 & 0 & 0.61 \\
\hline
\end{tabular}

The output gap then equals

$$
g a p_{t}=100\left(\log y_{b, l}-\log y_{b, t}^{*}\right)
$$

The gap is used throughout the model as an indicator of cyclical tensions with respect to price determination, capital formation and imports.

\subsection{Aggregate demand}

Summary. The components of aggregate demand are private consumption, residential and nonresidential investment, government consumption and government investment, inventory formation, and export and imports. Private consumption depends on real disposable household income and real financial and non-financial wealth, with the housing and capital stocks measured at market value. The direct substitution effect is captured by the inclusion of the longterm interest rate in the equation. In the short-run private consumption is also affected by changes in the unemployment rate reflecting the role of consumer confidence. Non-residential 
investment has already been discussed in Section 2.1. Residential investment is determined by real disposable household income and by real long and short-term interest rates. Real government consumption consists of an endogenous wage component and a residual part, which is exogenous or moves inline with real GDP (optional). Likewise, real government investment is exogenous or linked to real GDP. Inventory formation acts as a buffer for accommodating shocks in the short-run. In the long run, the inventory stock-to-sales ratio returns to equilibrium. In the short run, deviations may also be caused by changes in real interest rates. Exports depend on world trade and relative export prices. Import demand is governed mainly by sales and real import prices.

\section{Private consumption}

Private consumption is the main component of GDP. The consumption equation is derived from a standard model, whereby households optimise their expected discounted household utility subject to a wealth accumulation constraint (human and financial wealth). Furthermore, the optimisation procedure satisfies the no-Ponzi game condition such that the present value of consumption is equal to total wealth which is the sum of non human wealth and the present value of the stream of labour income anticipated. Following this approach current private consumption will be proportional to total household wealth. The presence of disposable income at current prices implies that a proportion of households faces liquidity constraints or follows "rules of thumb" behaviour. The remaining households' consumption, however, is determined by both their human and non-human wealth position. In the consumption equation we use a net wealth measure which includes the market value of domestic equity and the market value of the housing stock. We impose long-run linear homogeneity in real disposable income and real net wealth. The inclusion of the long-term interest rate captures the direct substitution effect between consumption and savings. There are also a number of variables that enter in the dynamic part of the consumption equation. Changes in unemployment capture a confidence factor which is on the whole an important determinant of consumption dynamics (consistently negative and very significant). Short term interest rates capture the short run effects on consumption/saving patterns.

$\log c_{t}=\beta_{c \mid} \log \frac{P D I_{t}}{p_{c, t}}+\left(1-\beta_{c^{\prime}}\right) \log \frac{N W_{M V^{\prime}, t}}{p_{c, t}}+\beta_{c 2}\left(r_{l, t}-\dot{p}_{c^{\prime}, t}\right)$

where

$c \quad=$ private consumption in real terms

$P D I=$ households' personal disposable income 


$$
\begin{array}{ll}
p_{c} & =\text { price deflator private consumption (index, } 1990=100) \\
N W_{M l} & =\text { net wealth private sector at market values } \\
r_{l} & =\text { nominal long-term interest rate (in \%) } \\
\dot{p}_{c} & =\text { inflation (in } \%) .
\end{array}
$$

Table 2.3 reports the long-run coefficients of equation (9). The UK and US exhibit the highest

\begin{tabular}{|c|c|c|c|c|c|c|c|c|c|c|c|c|c|}
\hline & $\mathrm{AU}$ & $\mathrm{BE}$ & $\mathrm{DE}$ & DK & ES & FI & FR & IT & $\mathrm{NL}$ & $\mathrm{SW}$ & UK & $\mathrm{JP}$ & US \\
\hline $\log \frac{P D I}{p_{c}}$ & 0.96 & 0.97 & 0.95 & 0.85 & 0.93 & 0.94 & 0.97 & 0.78 & 0.88 & 0.94 & 0.71 & 0.95 & 0.79 \\
\hline $\log \frac{N W_{t f l}}{p_{t^{\prime}}}$ & 0.04 & 0.03 & 0.05 & 0.15 & 0.07 & 0.06 & 0.03 & 0.22 & 0.12 & 0.06 & 0.29 & 0.05 & 0.21 \\
\hline$r_{i}^{--} \dot{p}_{c}$ & & & & & -0.0007 & -0.0009 & & & & & & & \\
\hline
\end{tabular}
elasticity of consumption with respect to wealth. Italy and to a lesser extent the Netherlands show similar features.

Table 2.3 Long-term parameter estimates of the private consumption equations

\section{Residential Investment}

In a similar way to private consumption, housing investment depends on real personal disposable income and the real interest rate.

$$
\log i_{h, t}=\log \frac{P D I_{t}}{p_{c, t}}+\beta_{i n}\left(r_{l, t}-\dot{p}_{c, t}\right)
$$

where

$$
\begin{array}{ll}
i_{h} & =\text { housing investment in real terms } \\
P D I & =\text { households' personal disposable income } \\
p_{c} & =\text { price deflator private consumption (index, 1990=100) } \\
r_{l} & =\text { nominal long-term interest rate (in \%) } \\
\dot{p}_{c} & =\text { inflation (in } \% \text { ). }
\end{array}
$$


The long-term interest rate captures the cost of housing investment except in the case of the UK where housing investment depends on variable mortgage rates. This is a specific feature of the UK market. Hence, for the UK the short-term interest rate is used as an explanatory variable. The long-run elasticities of residential investment with respect to real disposable income are calibrated to equal 1. Table 2.4 shows the long-run semi-elasticities for the interest rates.

Table 2.4 Long-term parameter estimates of the residential investment equations

\begin{tabular}{|c|c|c|c|c|c|c|c|c|c|c|c|c|c|}
\hline & $\mathrm{AU}$ & $\mathrm{BE}$ & $\mathrm{DE}$ & DK & ES & FI & FR & IT & $\mathrm{NL}$ & SW & UK & $\mathrm{JP}$ & US \\
\hline$r_{l}-\dot{p}_{c}$ & -0.02 & -0.06 & -0.04 & -0.02 & -0.01 & -0.08 & -0.02 & -0.01 & -0.06 & -0.10 & & -0.01 & -0.02 \\
\hline$r_{s}-\dot{p}_{c}$ & & & & & & & & & & & -0.02 & & \\
\hline
\end{tabular}

The housing stock, that plays a role in determining private sector wealth, accumulates in a similar way to non-residential capital:

$k_{h, t}=i_{h, t}+\left(1-\underline{\kappa}_{h}\right) k_{h, t-1}$

where

$k_{h} \quad=$ housing stock in real terms

$i_{h} \quad=$ housing investment in real terms

$\underline{\kappa}_{h} \quad=$ depreciation rate of housing stock.

\section{Inventory formation}

Instead of modelling inventory formation directly, we adopt Fair's (1984) approach. An equation for total final expenditures, $y_{e, t}$, defined as the sum of total sales and the change in inventory stocks, is postulated and estimated. The long-run specification of the relationship for total final expenditures is

$$
y_{c, t}=\beta_{\mathrm{r} 1} s_{t}+\beta_{\mathrm{r} 2} \frac{d u m_{i}}{i} t s_{t}+\beta_{\mathrm{v} 3} v_{t-1}
$$


where

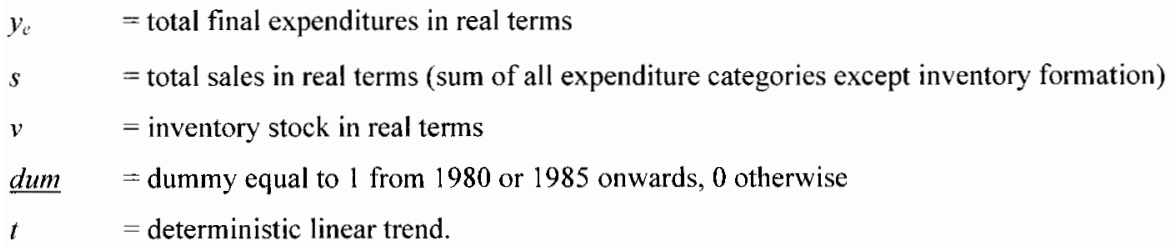

Several elements underlie this approach. First, it is assumed that there is some optimal ratio of the inventory stock to total sales. This ratio may be time-dependent to reflect technological changes in inventory management. Second, inventory formation depends on the discrepancy between the desired stock of inventories and the actual stock at the end of the previous period (therefore, the lagged inventory stock enters the equation). Third, it is assumed that due to costs of adjustment there is a tendency to smooth total final expenditures relative to total sales, confirmed by the estimation results. Table 2.5 shows the estimated long-run parameters of equation (12). In the short-run fluctuations in inventories may also be caused by changes in real interest rates.

Table 2.5 Long-term parameter estimates of the total final expenditures equations

\begin{tabular}{|c|c|c|c|c|c|c|c|c|c|c|c|c|c|}
\hline & $\mathrm{AU}$ & $\mathrm{BE}$ & $\mathrm{DE}$ & DK & ES & FI & FR & IT & NL & SW & UK & $\mathrm{JP}$ & US \\
\hline$s$ & 1.09 & 1.06 & 1.03 & 1.03 & 1.06 & 1.03 & 1.04 & 1.18 & 1.04 & 0.92 & 1.14 & 1.08 & 1.10 \\
\hline dum $t s$ & & -0.0002 & & & & & & & & & -0.0005 & -0.0001 & \\
\hline$v$ & -0.11 & -0.07 & -0.05 & -0.13 & -0.11 & -0.06 & -0.06 & -0.15 & -0.08 & -0.06 & -0.26 & -0.14 & -0.18 \\
\hline
\end{tabular}

Inventory formation then follows from

$$
\Delta v_{i}=y_{e, i}-s_{i}
$$

The inventory stock is the accumulation of inventory formation, i.e.

$v_{t}=v_{1-1}+\Delta v_{1}$ 


\section{Foreign Trade}

In defining export and import volumes, we assume that domestic and foreign goods and services are not perfect substitutes. This implies that the volume of exports will depend on world demand and competitiveness captured by relative export prices (export prices relative to a weighted average of competitors' export prices). Similarly, imports depend on final demand, captured by total sales, and the import price relative to domestic prices.

The long-run relationship for exports of goods and services is therefore specified as follows:

$$
\log x_{t}=\log m_{f}^{\mathrm{h}^{x}}+\beta_{x} \log \frac{p_{x, t}}{p_{x, t}^{w^{\prime}}}
$$

where

$x \quad=$ exports of goods and services in real terms

$m^{\text {4: }} \quad=$ relevant world trade (geographically weighted index, 1990=100)

$p_{x} \quad=$ price deflator exports of goods and services (index, 1990=100)

$p_{x}^{w} \quad=$ foreign export price (geographically weighted index, 1990=100).

The long-run elasticity of exports with respect to world trade is fixed at 1 for all countries. In the short run this elasticity may be lower. This implies that long-run changes in market share are driven by changes in price competitiveness. Estimating equation (15), however, has proved to give implausibly low figures for parameter $\beta_{x}$ for a number of countries. We have therefore taken the calibrating route. The long-run values for this parameter are shown for each country in Table 2.6 .

Table 2.6 Long-term parameter estimates of the export equations

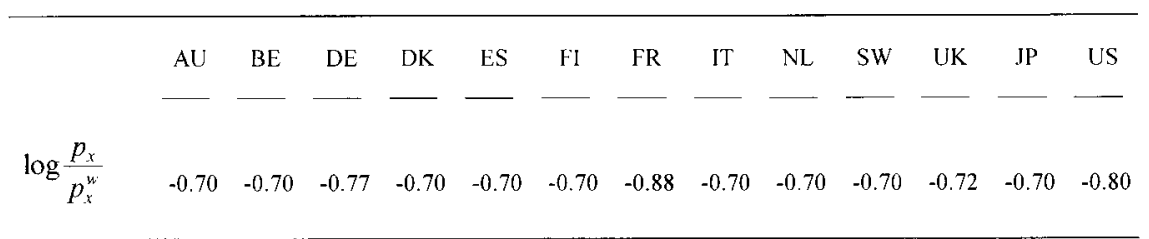


Real imports of goods and services are affected by sales and relative import prices:

$\log m_{t}=\log s_{t}+\beta_{m} \log \frac{p_{m, t}}{p_{y, t}}$

where

$m \quad=$ imports of goods and services in real terms

$s \quad=$ sales in real terms

$p_{m} \quad=$ price deflator imports of goods and services (index, 1990=100)

$p_{y} \quad=$ price deflator gross domestic product (index, 1990=100).

Equation (16) implies that the long-run sales elasticity of imports is assumed to be equal to 1 . Estimated long-run price elasticities of imports are fairly low for the EU-countries, as shown in Table 2.7.

Table 2.7 Long-term parameter estimates of the import equations

\begin{tabular}{|c|c|c|c|c|c|c|c|c|c|c|c|c|c|}
\hline & $\mathrm{AU}$ & $\mathrm{BE}$ & $\mathrm{DE}$ & DK & $\mathrm{ES}$ & $\mathrm{FI}$ & FR & $\mathrm{IT}$ & $\mathrm{NL}$ & SW & UK & $\mathrm{JP}$ & US \\
\hline $\log \frac{p_{m}}{p_{y}}$ & -0.06 & -0.25 & -0.10 & -0.17 & -0.38 & -0.15 & -0.33 & -0.31 & -0.13 & -0.12 & -0.32 & -0.52 & -0.73 \\
\hline
\end{tabular}

In the short run the cyclical stance, measured by movements in the output gap and changes in inventory formation relative to sales, also affects import volumes. Autonomous patterns in import penetration are captured by a deterministic time trend.

\subsection{Prices and costs}

Summary. Export prices are driven by competitors' prices and domestic prices. Import prices are mainly driven by commodity prices and a world import price, which is a geographically weighted average of national export prices. Domestic unit labour costs affect import prices only in the short run. The private consumption deflator is the central price variable in EUROMON. In the long-run consumer prices depend on unit labour costs, the mark-up and indirect tax rates. Oil prices have a small direct impact, reflecting the direct consumption of oil-related energy by 
households. Competitors' prices and cyclical indicators affect the mark-up of prices over the costs of production. Wage formation reflects a bargaining framework according to which equilibrium wages depend on consumer and producer prices, productivity, the unemployment rate and the rates of income tax and social security premiums. Both static and dynamic homogeneity are imposed to ensure that nominal variables do not affect the equilibrium level of unemployment.

\section{Export and import prices}

As argued by Jeanfils (2000) in an environment of monopolistic competition, domestic exporters can, up to a certain extent, decide on the level of prices. They thus set their export prices in relation to both domestic output prices as well as foreign export prices. Similarly, importers allow for both the behaviour of international competitors as well as domestic prices to determine prices, in line with the 'pricing to markets' hypothesis.

Export prices are homogeneous in domestic output prices and world export prices, i.e.:

$\log p_{x, t}=\beta_{p x} \log p_{x, t}^{w}+\left(1-\beta_{p x}\right) \log p_{y, t}$

with

$p_{x} \quad=$ price deflator exports of goods and services (index, 1990=100)

$p_{x}^{w} \quad=$ foreign export price (geographically weighted index, 1990=100)

$p_{y} \quad=$ price deflator gross domestic product $($ index, 1990=100).

Table 2.8 reports the estimated coefficients of equation (17). For small, open economies like the Netherlands and Belgium we find that world prices are relatively important in exporters' pricesetting decisions.

Table 2.8 Long-term parameter estimates of the export deflator equations

\begin{tabular}{lcccccccccccccccc}
\hline & $\mathrm{AU}$ & $\mathrm{BE}$ & $\mathrm{DE}$ & $\mathrm{DK}$ & $\mathrm{ES}$ & $\mathrm{FI}$ & $\mathrm{FR}$ & $\mathrm{IT}$ & $\mathrm{NL}$ & $\mathrm{SW}$ & UK & JP & US \\
$\log p_{y}$ & 0.62 & 0.40 & 0.79 & 0.54 & 0.67 & 0.55 & 0.65 & 0.42 & 0.38 & 0.34 & 0.67 & 1.00 & 0.57 \\
$\log p_{x}^{w}$ & 0.38 & 0.60 & 0.21 & 0.46 & 0.33 & 0.45 & 0.35 & 0.58 & 0.62 & 0.66 & 0.33 & & 0.43 \\
\hline
\end{tabular}


The long-run import price equation is described as follows:

$\log p_{m, t}=\beta_{p m 1} \log \underline{p}_{m i l, t}+\beta_{p m 2} \log \underline{p}_{c i m, t}+\left(1-\beta_{p m 1}-\beta_{p m 2}\right) \log p_{m, t}^{n \prime}$

with

$p_{m} \quad=$ price deflator imports of goods and services (index, 1990=100)

$p_{m}^{w} \quad=$ world import price in national currency (weighted export prices index, 1990=100)

$p_{c o m}=$ commodity prices excluding oil in national currency (index, 1990=100)

poil $=$ oil prices in national currency (index, 1990=100).

The current version of the model has pricing to markets for imports appearing only as a short-run phenomenon. Domestic prices as well as unit labour costs affect prices therefore, only in the short-run. Applying this in the long-run as well is part of our future changes in the model. The long-run coefficients, reported in Table 2.9 , are calibrated in line with the observed decomposition of imports in recent years.

Table 2.9 Long-term parameter estimates of the import deflator equations

\begin{tabular}{|c|c|c|c|c|c|c|c|c|c|c|c|c|c|}
\hline & $\mathrm{AU}$ & $\mathrm{BE}$ & $\mathrm{DE}$ & $\mathrm{DK}$ & $\mathrm{ES}$ & FI & FR & $\mathrm{IT}$ & $\mathrm{NL}$ & SW & UK & $\mathrm{JP}$ & US \\
\hline $\log p_{m}^{w}$ & 0.82 & 0.77 & 0.78 & 0.79 & 0.75 & 0.78 & 0.80 & 0.76 & 0.79 & 0.85 & 0.83 & 0.51 & 0.83 \\
\hline $\log \underline{p}_{o i l}$ & 0.07 & 0.08 & 0.09 & 0.05 & 0.10 & 0.10 & 0.08 & 0.08 & 0.08 & 0.06 & 0.04 & 0.24 & 0.10 \\
\hline $\log \underline{p}_{c i m}$ & 0.11 & 0.15 & 0.13 & 0.16 & 0.15 & 0.12 & 0.12 & 0.16 & 0.13 & 0.09 & 0.13 & 0.25 & 0.07 \\
\hline
\end{tabular}

\section{Wages and prices}

EUROMON embeds a collective bargaining model of wage determination between workers and firms. This is very similar to the process described in Layard et al. (1992) and Peeters and Den Reijer (2002). Workers are assumed to seek a given real consumption wage that satisfies their aspirations, whereas firms are seeking to achieve a given mark-up over costs. From the bargaining model a long-run wage curve emerges: 
$\log w_{h, t}=\kappa \log p_{c, t}+(1-\kappa) \log p_{y h, t}+\log l p_{h, t}+\gamma_{h^{\prime}} u_{t}+\gamma_{w 2} \log \left(1+\underline{\tau}_{t}\right)$

where

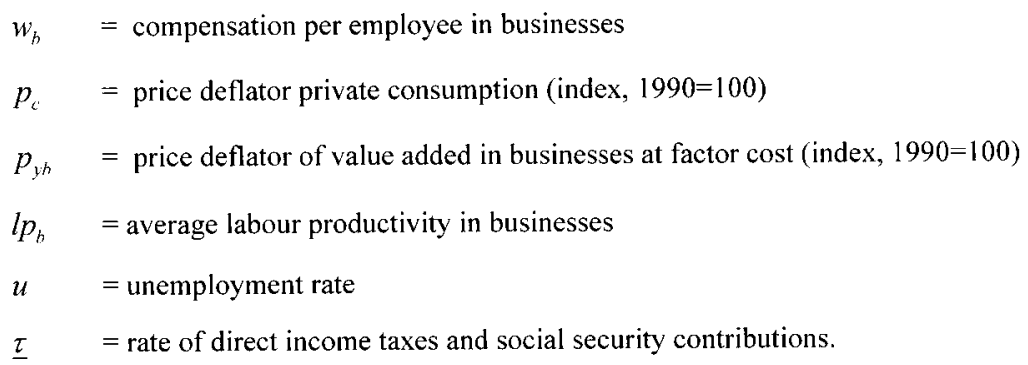

The latter variable enters the equation because the fallback position of workers outside the formal job market includes household production and working in the informal sector. Table 2.10 reports the long-run estimated coefficients for the wage equation. The long-run elasticities for labour productivity and the price level are assumed to be 1 . The price level is calculated as a geometric average of the consumer and producer price levels with $\kappa$ fixed at 0.5 .

Table 2.10 Long-term parameter estimates of the firms' wage rate equations

\begin{tabular}{|c|c|c|c|c|c|c|c|c|c|c|c|c|c|}
\hline & $\mathrm{AU}$ & $\mathrm{BE}$ & DE & $\mathrm{DK}$ & ES & $\mathrm{FI}$ & FR & IT & $\mathrm{NL}$ & SW & UK & $\mathrm{JP}$ & US \\
\hline $\log (1+\underline{\tau})$ & 0.10 & 0.10 & 0.40 & 0.40 & 0.40 & 0.10 & 0.40 & 0.10 & 0.30 & 0.22 & 0.10 & 0.10 & 0.10 \\
\hline$u$ & -0.016 & -0.036 & -0.009 & -0.012 & -0.014 & -0.014 & -0.022 & -0.042 & -0.025 & -0.011 & -0.016 & -0.010 & -0.010 \\
\hline
\end{tabular}

The private consumption deflator is the central price variable in the model. It is determined as a mark-up on unit labour costs, allowing for the effects of changes in indirect taxes on prices. The mark-up is mainly driven by import prices reflecting pressures from foreign producers. The output gap is found to play a role in price dynamics only in a few countries. The long-run equation for the private consumption deflator is as follows:

$\log p_{c^{\prime}, l}=\gamma_{p c \mathrm{l}} \log u l c_{i}+0.01 \log p_{o, t, 1}+\left(1-\gamma_{p c l}-0.01\right) \log p_{m, t}+\log \left(1+\underline{\tau}_{i n d, t}\right)$ 
where

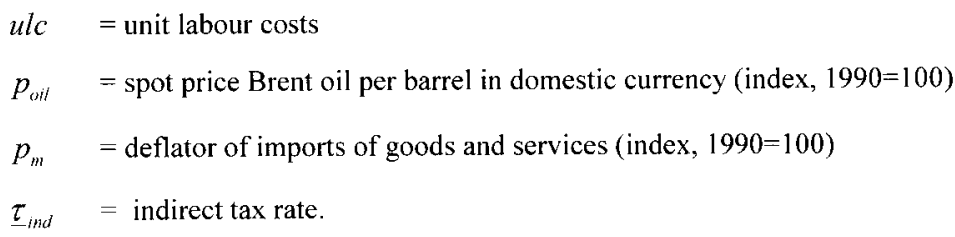

The direct oil price effect is small and calibrated. It reflects the share of direct consumption of oilrelated energy by households. In the short and long run changes in indirect tax rates are fully incorporated into consumer prices, i.e. a 1 percentage point increase in the rate of indirect taxes results in a $1 \%$ higher price level. Table 2.11 shows the estimated coefficients for equation (20). Quite clearly import prices have a larger impact on domestic prices in the smaller, more open economies.

Table 2.11 Long-term parameter estimates of the private consumption deflator equations

\begin{tabular}{|c|c|c|c|c|c|c|c|c|c|c|c|c|c|}
\hline & $\mathrm{AU}$ & $\mathrm{BE}$ & $\mathrm{DE}$ & $\mathrm{DK}$ & ES & $\mathrm{FI}$ & FR & $\mathrm{IT}$ & $\mathrm{NL}$ & $\mathrm{SW}$ & UK & $\mathrm{JP}$ & US \\
\hline $\log u l c$ & 0.86 & 0.64 & 0.89 & 0.77 & 0.92 & 0.81 & 0.89 & 0.87 & 0.84 & 0.91 & 0.92 & 0.92 & 0.90 \\
\hline $\log \underline{p}_{0 i l}$ & 0.01 & 0.01 & 0.01 & 0.01 & 0.01 & 0.01 & 0.01 & 0.01 & 0.01 & 0.01 & 0.01 & 0.01 & 0.01 \\
\hline $\log p_{m}$ & 0.13 & 0.35 & 0.10 & 0.22 & 0.07 & 0.18 & 0.10 & 0.12 & 0.15 & 0.08 & 0.09 & 0.07 & 0.09 \\
\hline
\end{tabular}

The equation representing the equilibrium level for producer prices at factor costs reads as follows:

$\log p_{y h, i}=\log p_{c, t}-\log \left(1+\underline{\tau}_{i n d, l}\right)$

where $\underline{\tau}_{\text {ind }}$ represents the indirect tax wedge between consumer and producer prices. The level of unemployment which reconciles firms' and unions' real claims can thus be determined by solving for the equilibrium levels of wages and prices (see also Broer et al., 2000). Combining the above equations yields the following result for the equilibrium rate of unemployment $\bar{u}$ : 
$\bar{u}_{t}=\frac{1}{\gamma_{w+1}}\left\{\frac{1-\gamma_{p c 1}}{\gamma_{p c t}}\left(\log p_{y h, t}-\log p_{m, t}\right)-\kappa \log \left(1+\underline{\tau}_{i n k t, t}\right)-\gamma_{w \cdot 2} \log \left(1+\underline{\tau}_{t}\right)\right\}$

This expression shows that the equilibrium rate of unemployment is a function of the real exchange rate and the tax wedge terms. Although in principle the model solves for the equilibrium unemployment rate, the simulations performed in actual fact make use of the exogenous natural rate (NAWRU) derived according to Elmeskov's (1993) procedure as described in the Aggregate Supply section. We plan to amend this inconsistency in our future work on the model by incorporating the equilibrium unemployment rate, as in (22), in the supply side of the model. That would improve the model's potential as a tool for analysing the effects of structural reforms.

\subsection{Government sector}

\section{Government revenues}

The government sector is treated in some detail. At the revenue-side income taxes, social security premiums, corporate taxes and indirect taxes are modelled separately. Direct taxes on personal income are the product of an average tax rate and a tax base, consisting of the wage sum and other household income including net transfers received from the government (net of social security contributions paid to the government). Likewise, corporate taxes are the product of the corporate tax rate and a tax base which equals corporate cash flows net of depreciation allowances and interest payments by firms. Indirect taxes are linked to private consumption.

\section{Government expenditures}

We distinguish five expenditure categories: government consumption disaggregated into government wages and non-wage consumption, government investment, transfers, interest payments on government debt, and other expenditures. Government employment is exogenous, whereas government wages move in line with private sector wages. Non-wage government consumption and government investment are either fixed in real terms or move in line with real GDP. Government transfers are a constant fraction of GDP, unless unemployment changes. If unemployment rises, transfers increase relative to GDP. Other government expenditures are constant in terms of GDP. 


\section{Fiscal solvency}

In the current model version fiscal solvency is implemented by targeting the government deficitto-GDP ratio, using personal income tax rates as instruments. However, in principle expenditure categories could also be used for stabilising government finances in the long run.

\subsection{Monetary and financial sector}

Summary. The three-month short-term interest rate plays the role of the instrument of monetary policy. Various feedback rules, such as the Taylor-rule, are optional. The monetary and financial sector of the model consist further of behavioural equations for long-term interest rates, broad money (M3), bank loans to the private sector, and equations for exchange rates and equity and house prices. Long-term interest rates depend on short rates and potentially on other variables such as inflation and government financial balances. Various options for modelling long rates may be considered. Money demand is homogenous in income and private sector net financial wealth, and furthermore depends on short and long-term interest rates and inflation. In the long run, the demand for bank loans is determined by the condition that interest payments on bank loans evolve in line with nominal income. Note that M3 and bank loans are not fully recursive. Changes in both feed into aggregate demand via the income channel of monetary transmission. This effect is however typically small. Exchange rates may be fixed in real terms, or be determined according to the uncovered interest parity condition (UIP) or by a combination of long-term purchasing power parity (PPP) and short-term (UIP). Equity prices depend on profitability and interest rates, and real house prices are determined by real disposable income relative to the housing stock, real interest rates and the relative price of residential investment. Equity and house prices affect private consumption via endogenous private sector net wealth measured at market value.

\section{Short-term interest rates}

The main instrument of monetary policy in EUROMON is the three-month short-term interest rate. In the current version of the model it may be treated as an exogenous variable or may follow from a policy instrument feedback rule. Possible rules include fixed real interest rates, strict or flexible inflation targeting (Taylor rule), and money growth targeting. EMU, US, UK and Japan have an independent monetary policy. For the sake of brevity we now only focus on the Taylor rule (ignoring constants): 
$r_{s, t}=\rho_{r} r_{s, t-1}+\left(1-\rho_{r}\right)\left[\underline{\phi}^{I T}\left(\dot{p}_{c, t}-\dot{p}^{T}\right)+\underline{\phi}^{g(q)} g a p_{t}\right]$

where

$r_{s}=$ nominal short-term interest rate (in \%)

$\phi^{I T} \quad=$ weight on the inflation target in the interest rate rule

$\dot{p}_{c} \quad=$ inflation in terms of the private consumption deflator (in \%)

$\dot{p}^{T} \quad=$ inflation target (in \%)

$\phi^{\text {gap }}=$ weight on output gap in the interest rate rule

gap = output gap (in \%)

$\rho_{r} \quad=$ degree of policy smoothing.

Although Denmark and Sweden are not EMU members, their policy-controlled interest rate is assumed to follow that of the euro area.

\section{Long-term interest rates}

European countries' long-term interest rates (10-year government bond yields) have converged within Europe since the beginning of the $1980 \mathrm{~s}$. This has been the result of international capital market liberalisation and, for the more recent past, the advent of EMU. Two modelling options are available for long-term interest rates in the current model version. The first allows for an empirical explanation from short rates, inflation rates and government financial balances (see also De Bondt et al., 1997). The second adheres strictly to a backward looking term structure. A third option, a forward looking term structure relationship, requires additional effort in terms of developing further the theory-consistency of the model as a whole.

With reference to the first option, the long-term interest rates in Germany (superscript DE), the UK and Japan are affected in the long run by their US or German counterparts, the domestic short-term interest rate, the domestic inflation rate and by domestic government financial balances as a percentage of GDP, i.e.

$r_{l, l}=\beta_{r 1} r_{l, t}^{l S}+\beta_{r 2}\left(r_{s, t}-\dot{p}_{c, l}\right)+\beta_{r 3} \dot{p}_{c, t}+\beta_{r 4} G F B Y_{t}$ 
where

$r_{1} \quad=$ nominal long-term interest rate Germany, UK, Japan or US

$r_{l}^{l / S} \quad=$ US nominal long-term interest rate (in \%)

$r$ = nominal short-term interest rate Germany, UK, Japan or US (in \%)

$\dot{p}_{c} \quad=$ inflation Germany, the UK, Japan or the US (in \%)

$G F B Y=$ government financial balance ratio (\% GDP).

The German and Japanese long rates are partially explained by the US long rate in the long run, so that $\beta_{r 1} \neq 0$. The US long rate dominates world capital markets. Equations for all remaining European countries have been estimated over the sample period covering the last two decades. We attempt to explain each country's long-term interest rate differential with Germany in terms of short-term interest rate differentials, inflation differentials, and differentials in government financial balances as a proportion of national GDP, i.e.:

$r_{l, t}-r_{l, t}^{D D E}=\beta_{r 5}\left(r_{s, t}-\dot{p}_{c, t}-r_{s, t}^{D l t}+\dot{p}_{c, t}^{D E E}\right)+\beta_{r, 6}\left(\dot{p}_{c, t}-\dot{p}_{c, t}^{D L E}\right)+\beta_{r, 7}\left(G F B Y_{t}-G F B Y_{t}^{D L E}\right)$

Table 2.12 Long-term parameter estimates of the long-term interest rate equations

\begin{tabular}{|c|c|c|c|c|c|c|c|c|c|c|c|c|c|}
\hline & $\mathrm{AU}$ & $\mathrm{BE}$ & $\mathrm{DE}$ & DK & ES & $\mathrm{FI}$ & FR & IT & $\mathrm{NL}$ & $\mathrm{SW}$ & UK & $\mathrm{JP}$ & US \\
\hline$r_{i}^{(/ S}$ & & & 0.20 & & & & & & & & & 0.35 & \\
\hline$r_{i}^{L E}$ & & & & & & & & & & & & & \\
\hline$r_{s}-\dot{p}_{c}$ & & & 0.09 & & & & & & & & 0.33 & 0.42 & 0.68 \\
\hline$\dot{p}_{c}$ & & & 0.48 & & & & & & & & 0.72 & 0.52 & 0.96 \\
\hline$G F B Y$ & & & & & & & & & & & -0.25 & & -0.45 \\
\hline$r_{s}-\dot{p}_{c}-r_{s}^{D E}+\dot{p}_{c}^{D H}$ & 0.48 & 0.35 & & 0.09 & 0.56 & 0.80 & 0.12 & 0.71 & 0.87 & 0.20 & & & \\
\hline$\dot{p}_{c}-\dot{p}_{c}^{i l}$ & 0.30 & 0.37 & & 0.12 & 0.72 & 0.80 & 0.12 & 0.81 & 0.72 & 0.15 & & & \\
\hline$G F B Y-G F B Y^{D I}$ & -0.09 & -0.13 & & -0.12 & -0.32 & -0.44 & -0.19 & -0.80 & -0.12 & -0.24 & & & \\
\hline
\end{tabular}


Table 2.12 shows the estimated long-run coefficients for the equations explaining the long-term interest rates. As expected the US long rate has a significant impact on long rates elsewhere. In the short run this impact will even be larger. Again as expected, inflation and real interest rate differentials with Germany are less important for Denmark and Sweden than for most of the euro area countries. Government financial balances matter mostly in the US and Italy.

As a second option, long-term interest rates can be specified as a backward looking term-structure rule (see also NIESR, 2005, for a similar option in the multi-country model NiGEM albeit with different parameters). This rule is specified as

$\Delta r_{i, t}=0.8 \Delta r_{s, t}+0.2\left(r_{s, t-1}-r_{i, t-1}+0.5\right)$

\section{Broad money}

This equation is based on a standard model in which the demand for real money holdings depends, in the long-run, on a measure of output and a vector of returns on various assets. Beyond these, inflation enters as the opportunity cost of holding money rather than real assets and allows for explicit testing of long-run price homogeneity of money demand (see Coenen and Vega, 1999 and Fase, 1998). In practice, we model the demand for broad money in the long run using the following regressors: 1) real GDP as a measure of the volume of transactions, 2) net financial wealth to reflect the portfolio role for money, and 3) short-term or long-term interest rates and inflation. The specification of the long-run relationship for M3 therefore reads:

$\log \frac{M 3_{1}}{p_{c, t}}=\beta_{M 1} \log y_{t}+\left(1-\beta_{M 1}\right) \log \frac{N F W_{1}+E_{M V_{t}}}{p_{c, t}}+\beta_{M 2} r_{\mathrm{s}, t}+\beta_{M 3} r_{l, t}+\beta_{M 4} \dot{p}_{c, t}$

where

$\begin{array}{ll}M 3 & =\text { broad money } \\ p_{c} & =\text { price deflator private consumption (index, 1990=100) } \\ y & =\text { gross domestic product in real terms } \\ N F W & =\text { net financial wealth private sector } \\ E_{M V} & =\text { market value of domestic equity } \\ r_{s} & =\text { nominal short-term interest rate (in \%) } \\ r_{i} & =\text { nominal long-term interest rate (in \%) } \\ \dot{p}_{c} & =\text { inflation (in } \%) .\end{array}$


It is assumed that real M3 in linear homogeneous in real GDP and real net financial wealth, implying that an increase by $1 \%$ in both will ceteris paribus result in a $1 \%$ rise in real money balances. The short-term interest rate has a positive and significant effect on money demand reflecting the fact that $\mathrm{M} 3$ includes short-term savings deposits. An increase (decrease) in the short-term interest rate raises (lowers) the demand for these deposits. Long-term interest rates and inflation, on the contrary, affect money demand negatively. For some countries we also allow for the effect of the output gap in the short run, capturing potential additional cyclical effects on the demand for money (precautionary savings motive). Table 2.13 shows the estimates for the longrun coefficients for equation (27). The estimates indicate a relatively strong influence of real wealth on broad money demand in Germany, the Netherlands and the United Kingdom.

Table 2.13 Long-term parameter estimates for the money demand equations

\begin{tabular}{|c|c|c|c|c|c|c|c|c|c|c|c|c|c|}
\hline & $\mathrm{AU}$ & $\mathrm{BE}$ & $\mathrm{DE}$ & DK & ES & FI & FR & IT & $N L$ & SW & UK & $J P$ & US \\
\hline $\log y$ & 0.83 & 0.86 & 0.77 & 0.99 & 0.93 & 1.00 & 1.50 & 1.00 & 0.62 & 1.00 & 0.71 & 0.84 & 0.88 \\
\hline \multicolumn{14}{|c|}{$N F W+E_{M V}$} \\
\hline $\log p_{c}$ & 0.17 & 0.14 & 0.23 & 0.01 & 0.07 & & & & 0.38 & & 0.29 & 0.16 & 0.12 \\
\hline$r$ & 0.01 & & 0.01 & 0.02 & 0.02 & & & & 0.01 & & 0.02 & 0.02 & 0.04 \\
\hline$r_{i}$ & -0.01 & -0.03 & -0.05 & -0.03 & -0.01 & & -0.01 & -0.01 & & & & -0.05 & \\
\hline$\dot{p}_{c}$ & & & & -0.03 & -0.01 & & & -0.01 & & & & & \\
\hline
\end{tabular}

\section{Bank credit to the private sector}

Bank credit to the private sector consists of mortgages and of corporate and other loans to households and businesses. Credit is assumed to depend on the disposable income of households (net of investment income OI), the cash flow of firms net of corporate taxes and the level of interest rates. Here, the long-run relationship is specified as:

$$
\begin{aligned}
& \log C R D_{t}=\log \left(P D I_{t}-O I_{t}+C F_{t}-T_{d i h_{t}}\right) \\
& -\log \left\{\frac { 1 } { 1 6 0 0 } \sum _ { i = 0 } ^ { 3 } \left[\left\{\underline{\omega}_{(R D) B} \underline{\vartheta}_{(R D) B}+\left(1-\underline{\omega}_{(R I D B)}\right) \underline{\vartheta}_{(R I) H}\right\} r_{l, t-1}\right.\right. \\
& \left.\left.+\left\{\underline{\omega}_{(R l D B}\left(1-\underline{\vartheta}_{(R l D B}\right)+\left(1-\underline{\omega}_{(R l) B}\right)\left(1-\underline{\vartheta}_{(R D H}\right)\right\} r_{s, l-i}\right]\right\}
\end{aligned}
$$


where

$C R D=$ bank credit to private sector

PDI = households' personal disposable income

$O I=$ other household (investment) income

$\mathrm{CF} \quad=$ cash flow

$T_{\text {cirh }}=$ corporate taxes

$r_{l}=$ nominal long-term interest rate (in \%)

$r_{s} \quad=$ nominal short-term interest rate (in \%)

$\underline{Q}_{(K D B)}=$ share long-term credit in total bank credit to businesses

$\underline{Q}(K D H=$ share long-term credit in total bank credit to households

$\underline{\omega}_{(R I) B}=$ share businesses in total bank credit to private sector.

In the long run total interest payments on credit are a constant fraction of household and business sector after-tax income. Hence, the long-run elasticities of bank credit with respect to income and the relevant interest rate are 1 and -1 by assumption, respectively. The relevant interest rate is constructed as a weighted average of the long- and short-term interest rates.

\section{Exchange rates}

In the current version of the model we distinguish two options for modelling exchange rates: fixed real exchange rates and a combination of UIP and long-run PPP in backward looking mode. As with long-term interest rates, a forward looking third option, namely UIP, requires further strengthening the theory-consistency of EUROMON. The exchange rates of the euro, the pound sterling and the yen vis-á-vis the dollar are therefore modelled as follows:

Fixed real $\Delta \log e_{D O L, t}=\Delta \log p_{i, t}-\Delta \log p_{c, t}^{U / S}$

UIP/PPP

$$
\begin{aligned}
\log e_{D O I, t, t} & =\beta_{c 0}+\beta_{c 1} \log e_{D O L, t-1}+\left(1-\beta_{v 1}\right) \log \left(p_{c, t} / p_{c, t}^{U S}\right) \\
& -\left(r_{s, t}-r_{s, t}^{I S S}\right)+\beta_{c ! 1}\left(r_{s, t-1}-r_{s, t-1}^{L S}\right)
\end{aligned}
$$


where

$$
\begin{array}{ll}
e_{b O S} & =\text { nominal exchange rate, domestic currency per USD } \\
\dot{p}_{c} & =\text { inflation, in terms of the private consumption deflator (in \%) } \\
\dot{p}_{c}^{l / S} & =\text { idem, US inflation (in \%) } \\
r_{s} & =\text { nominal short-term interest rate (in \%) } \\
r_{s}^{l s} & =\text { nominal short-term interest rate US (in \%) } .
\end{array}
$$

\section{Equity prices}

For each country the equity price is explained by a long-run relationship combining the GDPdeflator, the labour income share (measured as the share of private sector wages in gross value added of businesses at factor costs) and the nominal long-term interest rate as determinants.

$$
\log p_{e q, t}=\log p_{y, t}+\beta_{c q !} l i s_{t}+\beta_{e q 2} r_{l, t}
$$

where

$$
\begin{array}{ll}
p_{e q} & =\text { equity price (index, 1990=100) } \\
p_{y} & =\text { price deflator gross domestic product (index, 1990=100) } \\
\text { lis } & =\text { business labour income share } \\
r_{l} & =\text { nominal long-term interest rate }(\text { in } \%) .
\end{array}
$$

The equity price is assumed to be homogeneous in the GDP-deflator in order to avoid price level shifts having an impact on real equity returns in the long run. The labour income share captures the impact of profitability on equity prices. A higher labour income share means lower profitability in the business sector, which is therefore attended by lower equity prices. The longterm interest rate serves as a proxy for the required yield on equity. Higher interest rates thus imply lower equity prices. Equity prices across EMU-countries and the US have displayed a strikingly similar pattern over longer horizons. For this reason, the estimated coefficients in the long-run relationship have been assumed to be equal across countries, by imposing cross-equation restrictions on parameters $\beta_{u, l}$ and $\beta_{u q 2}$. Short-term effects and adjustment speeds towards longterm equilibrium may however differ across countries. The estimation results for equation (31) are reported in Table 2.14 . 
Table 2.14 Long-term parameter estimates of the equity price equations

\begin{tabular}{|c|c|c|c|c|c|c|c|c|c|c|c|c|c|}
\hline & $\mathrm{AU}$ & $\mathrm{BE}$ & $\mathrm{DE}$ & DK & ES & FI & $\mathrm{FR}$ & IT & $\mathrm{NL}$ & SW & UK & $\mathrm{JP}$ & US \\
\hline lis & -0.54 & -0.54 & -0.54 & -0.54 & -0.54 & -0.54 & -0.54 & -0.54 & -0.54 & -0.54 & -0.54 & -0.54 & -0.54 \\
\hline $\log r_{l}$ & -0.08 & -0.08 & -0.08 & -0.08 & -0.08 & -0.08 & -0.08 & -0.08 & -0.08 & -0.08 & -0.08 & -0.08 & -0.08 \\
\hline
\end{tabular}

\section{House prices}

The housing market is characterized by an inelastic supply curve. Therefore, over the medium term house prices are mainly influenced by demand factors. As an important component of financing opportunities, households' personal disposable income is an important determinant of house prices. Furthermore, the costs of mortgage borrowing are dependent on both the short-term as well as the long-term interest rates. On the supply side, there are two important determinants, i.e. the existing housing stock and the relative price of residential investment which proxies the costs of building new houses and therefore reflects the opportunity cost of existing ones. For the US we find a lasting effect of the latter variable on real house prices, whereas in most of the other countries real house prices are affected by the relative price of residential investment only in the short run. Real house prices are thus determined in the long-run by real personal disposable income relative to the existing housing stock, real long-term interest rates and the relative construction cost price.

$\log \left(p_{h, t} / p_{c, t}\right)=\beta_{p h 1} \log \frac{P D I_{t} / p_{c, t}}{k_{h, t-1}}+\beta_{p h 2}\left(r_{l, t}-\dot{p}_{c, t}\right)+\beta_{p h 3} \log \left(p_{t h, t} / p_{c, t}\right)$

where

$\begin{array}{ll}p_{h} & =\text { house price } \\ p_{c} & =\text { price deflator private consumption (index, 1990=100) } \\ p_{i h} & =\text { price deflator residential investment (index, 1990=100) } \\ k_{h} & =\text { housing stock in real terms } \\ P D I & =\text { households' personal disposable income } \\ r_{l} & =\text { nominal long-term interest rate (in \%) } \\ \dot{p}_{c} & =\text { inflation (in \%). }\end{array}$


Table 2.15 shows the estimation results for the long-run coefficients of the housing price equation (32).

Table 2.15 Long-term parameter estimates of the house price equations

\begin{tabular}{|c|c|c|c|c|c|c|c|c|c|c|c|c|c|}
\hline & $\mathrm{AU}$ & $\mathrm{BE}$ & DE. & $\mathrm{DK}$ & ES & $\mathrm{FI}$ & FR & IT & NL & SW & UK & $\mathrm{JP}$ & US \\
\hline $\log \frac{P D I_{t} / p_{c, t}}{k_{h, t-1}}$ & 1.94 & 1.14 & 0.20 & 0.50 & 0.29 & 0.83 & 0.34 & 0.33 & 1.14 & 0.84 & 0.50 & 1.12 & 153 \\
\hline$\eta-\dot{p}_{c}$ & -0.052 & $=0.041$ & -0.028 & -0.028 & -0.012 & -0.013 & -0.034 & -0.050 & -0.060 & -0.038 & -0.001 & -0.049 & -0.014 \\
\hline $\log \frac{p_{i h}}{p_{c}}$ & & & & & & & & & & & & & 1.47 \\
\hline
\end{tabular}

\section{Monetary transmission}

The transmission of monetary policy to the real economy operates through various channels. In the short-run prices and output are affected by exchange rate responses as they impact on import prices and competitiveness. In the medium term cost-of-capital effects and direct substitution effects on the investment categories and on private consumption respectively, dominate the impact of monetary policy on output. A fourth channel of transmission is the wealth channel, which operates mainly through endogenous responses of house and equity prices. Finally, the income channel already mentioned, refers to changes in the net investment income flows received (or paid) by households, when interest rates change. This decomposition of monetary transmission is fairly standard in central bank models (see van Els et al., 2003a and 2003b; McAdam and Morgan, 2003). The wealth channel is however, somewhat special as it includes endogenous asset prices. 
In order to highlight EUROMON's properties as a tool for scenario and policy analysis a number of indicative model simulation results are presented in this chapter. The outcomes for the key euro area macroeconomic indicators have been produced by aggregation of the results for the eight individual euro countries in the model: Germany, France, Italy, Spain, Netherlands, Belgium, Austria and Finland. In 2003, these eight countries produced 94\% of the total euro area GDP. Hence, the aggregate results for these countries may be regarded as being representative of the euro area as a whole. The benefit of incorporating the United States, Japan and three other EU countries in the model - namely the United Kingdom, Sweden and Denmark - is that spillovers from external shocks originating in these countries are now explicitly modelled and can therefore be analyzed within a structured and consistent framework. The simulation results therefore clarify existing relationships between the various countries and country blocks.

The baseline projection, on which the scenarios have been run, relates to the period $2003 \mathrm{q} 1$ $2010 \mathrm{q} 4$. Since the model is borderline linear, the scenarios presented may be adjusted pro rata if the size of the shock is required to be changed. In addition, it is possible to combine the results of several alternative scenarios. For example, if required, the scenario of a sudden reduction in demand from outside the euro area, which only considers the effects on the euro area economy through the trade channel, can be combined with other additional confidence-related effects, such as a world-wide fall in share prices, or a depreciation of the dollar. A linear combination of these results will yield a reasonably accurate approximation of the true model results for the same linear combination of the shocks, provided that the shocks are not too large. The results will also not be particularly sensitive to the choice of a different baseline projection. However, recall that model outcomes remain an abstraction of reality Box 1 below lists the scenarios considered. The simulation results presented relate almost without exception to the euro area as a whole. Unless otherwise stated, the shocks have been given to all of the countries in the euro area simultaneously. In most cases, US results have been presented for comparison purposes. For a number of scenarios alternative settings have been tried. These alternative settings relate to different policy responses or to potential concomitant circumstances.

Standard scenarios say something about the simulation properties of a model in the first place. They cannot be applied automatically to actual policy issues under all circumstances. As a rule, quantifying the impact of a policy action generally requires that the model user is familiar with the structure and properties of the model and that the simulation design is tailored to the purpose of the simulation. The standard scenarios must therefore be used prudently and in this connection 


\section{Box 1 List of scenarios}

1. Reduction in the policy-controlled interest rate by 1 percentage point over 8 quarters

2. Worldwide reduction in capital market rates by 1 percentage point over 8 quarters

3. Permanent appreciation of the effective exchange rate of the US dollar by $10 \%$

4. Permanent appreciation of the effective exchange rate of the euro by $10 \%$

5. Permanent increase in non-wage government consumption by $1 \%$ of GDP

6. Permanent $e x$ ante balanced-budget reduction in income taxes by $1 \%$ of GDP in the euro area (accompanied by a reduction in non-wage government consumption)

7. Permanent increase in indirect taxation in the euro area equal to $1 \%$ of GDP

8. Increase in oil prices by $25 \%$ over 8 quarters

9. Reduction in domestic spending in the US, UK and Japan over 8 quarters

10. Autonomous increase in inflation in the euro area by 1 percentage point over 4 quarters

11. Reduction in house prices by $10 \%$ over 8 quarters

12. Worldwide fall in share prices by $25 \%$ over 8 quarters

13. Autonomous increase in the level of wages by $1 \%$ over 4 quarters

14. Permanent reduction in the labour supply in the euro area by $1 \%$

the following should be noted. The current version of the model is backward-looking, that is, the expectations of consumers and producers are not formed in a forward-looking way that is consistent with the model, but are extrapolations based upon past patterns. Work is being carried out on incorporating forward-looking expectations that are consistent with the model. This requires, inter alia, a further strengthening of the theoretical foundations of the model and, therefore of the long-term simulation properties. Ideally, the model will converge towards a steady state that is theoretically well founded and that will act as an anchor for forward-looking behaviour. This stage has not been reached yet. This process has been initiated by incorporating not only static, but also dynamic homogeneity of wages and prices. This will guarantee that in the long run nominal variables will not affect the natural rate of unemployment rate and potential output. The reverse of this dynamic homogeneity is that once price movements have been set in motion they can show a very persistent pattern. The scenarios show a number of examples of this.

This chapter will contain the following information. Section 3.1 provides further details on the simulation design, including the policy rules used for modelling endogenous monetary and budgetary policy. Section 3.2 presents the simulation outcomes for each scenario and offers a 
brief explanation of the main results. The outcomes are presented in tables, focusing on a number of key macroeconomic indicators for a maximum time horizon of six years.

\subsection{Simulation design and policy rules}

For a proper understanding and interpretation of the simulation outcomes, a number of issues have to be kept in mind. In most of the scenarios, the shock variables (i.e. interest rates, exchange rates, wage rates, share prices, house prices) are basically endogenous. During the period that the shock lasts (for instance the monetary policy shock is sustained for two years), the shock variable is kept exogenous. During the remainder of the simulation period the relevant equation is switched on again and the shock variable gradually moves towards the next level of equilibrium. Often this is the starting position. If a variable is exogenous, such as the oil price in dollars, then after the shock period, it returns immediately to its initial value.

EUROMON allows for simulations to be carried out under various assumptions concerning the response of interest rates, exchange rates and budgetary policy. For the sake of comparability all scenarios are based on the same assumptions, unless stated otherwise. These assumptions entail 1) the (monetary policy) short-term interest rate follows from a Taylor rule; 2) the long-term interest rate is modelled by a backward-looking term-structure rule; and 3) the exchange rate follows from an equation combining long-run purchasing power parity with uncovered interest rate parity in the short run. With respect to budgetary policy long-term fiscal solvency is assumed. This means that in the long run government budget deficits and, therefore, explosive growth paths of the public sector debt are ruled out. Further details on the implemented policy rules are given below.

\section{Monetary policy}

Each of the monetary authorities (of the euro area, the UK, Japan and the US) adjust the policycontrolled interest rate systematically according to a Taylor rule. In EUROMON, this is the threemonth interest rate. This means that the policy interest rate responds to the deviation of current inflation from an inflation target and to the deviation of actual output from potential output (the output gap) in line with equation (23). The implemented policy rules imply that the ECB applies a weight on the inflation rate that is twice that on the output gap. It is further assumed that in relative terms the Fed places slightly more emphasis on the output gap than the ECB. Both monetary authorities use an inflation target of $2 \%$. In the model simulations presented below, 
the monetary authorities respond immediately to deviations of actual inflation and output relative to their target levels (there is no policy smoothing). For Sweden and Denmark, monetary policies are assumed to run entirely in parallel with ECB policy.

\section{Long-term interest rates}

As the standard approach we assume that long-term interest rates follow the backward-looking term-structure relationship described by equation (26). This implies that in terms of deviations from baseline long rates catch up with the money market rate with some lag, whereby the term premium is restored within a fairly short time-span.

\section{Exchange rates}

The standard equation used here for the euro-dollar rate is backward-looking and reflects a combination of long-term purchasing power parity (of prices in the euro area relative to those in the US) and uncovered interest rate parity (the difference between the euro area and the US interest rate), as presented by equation (30). The effect of this equation is that the exchange rate is primarily determined by interest rate differentials in the short-term (an increase in interest rates leads to an appreciation of the domestic currency), whereas purchasing power parity holds in the long run. In general, our approach is in line with that followed in the Bundesbank's multi-country model.

\section{Fiscal solvency}

The nature of budgetary policy is such that long-term fiscal solvency is guaranteed, by modelling the income tax rate through a policy rule. According to this policy rule, the income tax rate responds to deviations of the government financial balance relative to its the original level (both expressed as a percentage of GDP) in such a way that, for example, budget deficits are removed gradually through an increase in the income tax rate. The precise speed at which budget deficits are removed depends not only on the policy rule used, but also on the macroeconomic impact of the shock in question and its interaction with the policy rule. One aspect of EUROMON's wage equations is that part of the burden of such increases in income tax rates will be passed on from employees to employers.

\section{Government expenditure}

In each of the simulations by assumption government consumption and investment are constant in real terms. However, nominal trends continue to feed through into the government budget. Government salaries for instance are assumed to be linked to wage growth in the private sector on 
a one-to-one basis. Unemployment benefits depend partly on the volume of unemployment. Other government expenditure remains constant as a percentage of GDP.

\subsection{Simulation results}

We present the results of the 14 standard scenarios listed in Box 1. The scenarios relate to monetary and budgetary policies as well as to exogenous external and internal shocks. Scenario 1 focuses on the impact of a monetary policy shock in the euro area and in the US, using various underlying assumptions for the behaviour of long-term interest rates and exchange rates.

Scenario 2 addresses the effects of a shock to long-term interest rates (term spread), while scenarios 3 and 4 focus on exchange rate shocks. Scenarios 5, 6 and 7 deal with fiscal and budgetary policies, scenario 8 with an oil price shock, scenario 9 focuses on an autonomous decline in domestic spending ("feel bad" factor), while scenario 10 addresses a temporary shock to inflation. Scenario 11 presents the effects of house price shocks originating both in the euro area and in the US, whereas scenario 12 deals extensively with a worldwide fall in share prices. Finally, scenarios 13 and 14 focus on the labour market, featuring a temporary autonomous wage shock and a permanent labour supply shock, respectively.

The numbering of the subsections is in line with that of the tables containing the simulation results. For a number of scenarios, alternative settings have been considered. In some cases, the alternative setting relates to concomitant circumstances or to shocks in individual countries. The results presented in the tables relate to the cumulative deviations relative to the baseline projection. For the majority of variables, these deviations from baseline are expressed in percentages (shown by $\mathrm{P}$ ), while for a smaller group of variables the deviations are expressed in absolute terms (shown by $\mathrm{A}$ ). As a rule, the absolute deviations relate to either percentage points or per cent of GDP, as in the case of the trade balance, the government financial balance and the public sector debt. 


\title{
3.2.1 Reduction in the policy-controlled interest rate by 1 percentage point over 8 quarters
}

\author{
A reduction in the euro area policy-controlled interest rate
}

In this scenario, the monetary policy interest rate in the euro area is kept exogenous over two years and reduced by 1 percentage point. Tables $3.1 \mathrm{a}$ up to and including Table $3.1 \mathrm{~d}$ report the impact of a reduction in the euro area policy rate on the economies of the euro area and the United States. Two versions of this scenario are presented. In the first version (Table 3.1a and Table 3.1b) it is assumed that long-term interest rates react according to the backward-looking term structure rule described in equation (26), while exchange rates follow equation (30), reflecting the combination of long-term purchasing power parity and short-term uncovered interest parity. In the second version (Table 3.1c and Table 3.1d) euro area long-term interest rates and exchange rates are forward-looking in line with the expectation hypothesis of the yield curve and uncovered interest rate parity, respectively.

\section{Tables $3.1 a-3.1 b$}

Focussing on the first version, Table 3.1a shows the results for the euro area. Owing to the assumption of a constant term spread in the long run, the long-term interest rate follows the short rate fairly rapidly. Falling interest rates act as an important stimulus for business and housing investment in particular. Private consumption also benefits from the increase in real disposable income, which is mainly due to higher wage growth in a tighter labour market, but is also partly attributable to slightly lower tax rates in response to a more favourable government financial position (initially due to reduced interest payments and thereafter to growth in tax revenues). After three years, the cumulative rise of real GDP relative to baseline reaches $0.6 \%$, which is accompanied by a $0.5 \%$ higher output gap. From year 3 onwards, the policy interest rate is again determined in line with the Taylor rule. The positive output gap and the upturn in inflation (by and large 0.4 percentage points higher) cause monetary authorities to raise interest rates from -1.0 percentage point relative to baseline in year 2 to +0.9 percentage point in year 3 . The rise in real interest rates causes output and employment to gradually revert to their baseline levels and halts the rise in inflation. As Table 3.1b shows, the impact of the reduction in the policy-controlled interest rate in the euro area on the US economy is very moderate.

\section{Tables $3.1 c-3.1 d$}

In the second version of this monetary policy scenario euro area long-term interest rates and exchange rates are forward-looking and respond according to the expectation hypothesis of the yield curve and uncovered interest rate parity, respectively. It is further assumed that risk premia remain unchanged and that financial markets do not foresee the relaxation of monetary policy, but 
are aware that the interest rate cut will be maintained for two years. As a resuit, the long-term rate in the euro area falls much less sharply, namely by 0.17 percentage points in the first year and by 0.06 percentage points in the second year. Since spending in the euro area is particularly sensitive to changes in the long-term interest rate, the macroeconomic effects of the relaxation of monetary policy are now smaller compared to the results in the first version of this scenario. Real GDP in the euro area increases by a maximum of about $0.25 \%$, while inflation increases by less than 0.2 percentage points (see Table 3.1c). The impact on the US economy (Table 3.Id) is again very limited.

\section{A reduction in the US policy-controlled interest rate}

We report three versions of this scenario. In the first version (Table 3.1e and Table 3.1f) it is assumed that long-term interest rates react according to the backward-looking term structure rule described in equation (26), while exchange rates follow equation (30), reflecting the combination of long-term purchasing power parity and short-term uncovered interest parity. In the second version (Table 3.1g and Table 3.1h), US long-term interest rates and exchange rates are forwardlooking in line with the expectation hypothesis of the yield curve and uncovered interest rate parity, respectively. In the third version (Table $3.1 \mathrm{i}$ and Table 3.1j), we presume that long-term interest rates in Germany, the United Kingdom and Japan respond according to the estimated relationships as described by equation (24), while the long-term rates in the other euro area countries follow the process described in equation (25). In this third approach the long-term interest rate spillovers from the US to other countries are more direct and larger, notably in the short run.

\section{Tables 3.1e-3.1f}

The results for the US economy are presented in Table 3.1f. The 1 percentage point reduction in the US policy-controlled interest rate sustained for two years has a larger impact on the US economy than a euro area monetary policy shock has on the euro area economy (see Table 3.1a). After two years, US real GDP is $1.2 \%$ above the base level. Both US investment and consumption are more sensitive to the reduction in interest rates than their euro area counterparts. Moreover, the US economy responds faster to the relaxation of monetary policy than the euro area economy. US business employment reaches its maximum effect in year 2 and $3(+0.75 \%)$, while in the euro area the maximum impact $(+0.35 \%)$ is reached in year 3 and 4 . The impact of the reduction in the US policy-controlled interest rate on the euro area economy is very modest (Table 3.1e). This is due to the lack of direct interest rate spillovers in the present set-up. 
Tables $3.1 \mathrm{lg}-3.1 \mathrm{~h}$

Focusing on Table $3.1 \mathrm{~h}$, the effects of the relaxation of monetary policy on the US economy are now much smaller due to the relatively modest response of the US capital market rate in the present setting. After two years, US real GDP is only $0.3 \%$ higher, compared to $1.2 \%$ under the assumption of a constant yield curve in the previous scenario (Table 3.1f). So, in EUROMON the response of long-term interest rates clearly determines the strength of the monetary transmission process. Again, note that for the present setting too, according to EUROMON monetary policy shocks have a larger impact in the US than in the euro area.

\section{Tables 3.1i-3.1j}

We now repeat the same simulation under the assumption that changes in US interest rates have direct and larger spillover effects to interest rates elsewhere, according to the estimation results of equation (24) for the long-term interest rate as presented in Table 2.12. Using these equations, the response of the US long-term interest rate itself stands midway between the responses in the previous two scenarios. Not surprisingly, the same holds for the effects on key US macroeconomic indicators such as real GDP and inflation (see Table 3.1j). In contrast with the previous scenarios, lower US capital market rates now directly spill over to the euro area (see Table 3.1i). As a result, real GDP in the euro area benefits more from the relaxation of US monetary policy, although the effects remain fairly modest.

\subsubsection{Worldwide reduction in capital market rates by 1 percentage point over 8 quarters}

Tables $3.2 \mathrm{a}$ and $3.2 \mathrm{~b}$ for the euro area and the US, respectively, present the results of a simultaneous reduction in the capital market interest rates in all countries considered in the model. Long-term interest rates are thus kept exogenous for two years and reduced by 1 percentage point; from year 3 onwards, they are again endogenous. This scenario can be regarded as an illustration of the effects of a temporarily lower risk premium. The reduction in the real long-term rate acts as a stimulus to consumer spending and investment. Business employment rises and the unemployment rate falls. As a result, wage growth accelerates, resulting in higher inflation. The central bank responds to the increased output gap and inflation by raising the monetary policy interest rate, even after the shock to the long-term rate has ended in year 3 . As mentioned earlier, the effects in the US are stronger and adjustment processes are faster than in the euro area. The maximum effect on US real GDP occurs in year $2(+1.1 \%)$, whereas in the euro area real GDP reaches its biggest effect in year $3(+0.7 \%)$. The inflationary effects of lower interest rates are more persistent in the euro area. 


\subsubsection{Permanent appreciation of the effective exchange rate of the US dollar by $10 \%$}

The exchange rates are exogenous over the entire simulation horizon, and the US dollar appreciates by $10 \%$ on a permanent basis against all other currencies. This is attended by a $2.4 \%$ effective depreciation of the euro. Euro area exports rise and imports decline, resulting in a $0.1 \%$ rise of real GDP in the short run (Table 3.3a). However, higher inflation erodes private consumption and triggers a rise of the policy-controlled and capital market interest rates in the euro area, which forces real GDP to fall below baseline in the medium term.

For the US the effective appreciation of its currency by $10 \%$ is accompanied by a substantial weakening of competitiveness and a subsequent fall in exports (Table 3.3b). Real GDP declines relative to baseline by a maximum of $0.6 \%$ in year 3 . The lower inflation and output gap lead to lower interest rate levels, which will cause spending to rise again in the medium term.

\subsubsection{Permanent appreciation of the effective exchange rate of the euro by $10 \%$}

In a similar exercise, the euro appreciates by $10 \%$ against all other currencies on a permanent basis. Table 3.4a gives the results for the euro area. In the short run, the effective appreciation of the euro by $10 \%$ leads to a fall in real GDP by $0.4 \%$ that is mainly caused by the decline in exports to countries outside the euro area. Lower import prices drive inflation down, contributing to a substantial interest rate cut which triggers a recovery of the euro area economy and causes output to rise above its baseline level as from year 4 .

For the US the appreciation of the euro boils down to an effective dollar depreciation by $3.4 \%$ (Table 3.4b). This improves US competitiveness vis-à-vis the euro area and leads to an increase in real GDP by approximately $0.2 \%$. In the longer term, however, imported inflation cancels out this positive stimulus through an increase in interest rates.

\subsubsection{Permanent increase in non-wage government consumption by $1 \%$ of GDP}

Under this heading we present three different scenarios. The first scenario shows the effects of a permanent increase in non-wage government consumption by $1 \%$ of GDP in all euro area countries for the euro area itself (Table 3.5a) and for The Netherlands (Table 3.5b). The second scenario repeats this exercise, now assuming that government consumption only rises in the three largest euro area economies: Germany, France and Italy. Again, we show the results for the euro area as a whole (Table 3.5c) and for the Netherlands (Table 3.5d). By differentiating between 
countries, we exploit the potential of a multi-country model. The third scenario concentrates on the effects of a permanent increase in US non-wage government consumption for the euro area (Table $3.5 \mathrm{e}$ ) and the US itself (Table $3.5 \mathrm{f}$ ).

Permanent increase in non-wage government consumption by $1 \%$ of GDP in the euro area

A permanent increase in non-wage government consumption in the euro area by $1 \%$ of GDP is a large demand shock. Initially, through the accelerator mechanism, it induces additional business investment, but is also accompanied by an increase in imports which moderates the impact on domestic output. Overall, euro area real GDP is $0.9 \%$ higher in the first year (Table 3.5a). The higher output gap (indicating a rise in future inflation) and, later, higher inflation itself drive up the policy-controlled interest rate. The reduction in unemployment generates higher wages. Pressure on wages is further reinforced by the increase in income tax rates which aim to guarantee sustainability of government finances. Employees will pass on part of tax burden to employers by negotiating higher wages. As from year 3, the increase in tax rates leads to a lower real personal disposable income, which together with higher interest rates contributes to a reduction in consumer spending. After 6 years, real GDP in the euro area is $0.3 \%$ lower compared to its baseline level and consumer prices are about $3 \%$ higher.

The same mechanisms play a role in the Netherlands (Table 3.5b). As the openness of the Dutch economy is relatively strong, a larger part of the domestic fiscal stimulus leaks away to foreign countries. This explains why initially the impact on real GDP is relatively small in comparison to the euro area.

Permanent increase in non-wage government consumption by $1 \%$ of GDP in France, Germany and Italy

This scenario concentrates on the effects of an increase in non-wage government consumption in France, Germany and Italy only. As Table 3.5c illustrates, the effects for the euro area are lower than before but still substantial. Real GDP increases in the first year by almost $0.7 \%$. Important differences relative to the previous scenario are evident, particularly in the euro countries that are not implementing the budgetary relaxation, including the Netherlands (Table $3.5 \mathrm{~d}$ ). Although the Dutch economy still benefits from higher exports to notably France, Germany and Italy, it is immediately adversely affected by the increase in the policy-controlled and capital market interest rates in the euro area. On balance the negative impact of higher real interest rates prevails as from year 4 . 


\section{Permanent increase in non-wage government consumption by $1 \%$ of GDP in the US}

Table 3.5e illustrates the effects of permanent 1\% GDP increase in non-wage government consumption in the US on the euro area. One may conclude from this that a budgetary stimulus in the US, at least without additional (confidence) effects, only has a modest impact on the economy of the euro area through the usual trade spillovers. Table $3.5 \mathrm{f}$ shows the results for the US itself. The positive impact of the increase in government spending on real GDP initially is larger in the US than it is in the euro area (compare with Table 3.5a). This is caused by a sharper increase in business investment in the US. A further conclusion is that the effect of the budgetary stimulus in the US wears off more rapidly and is less inflationary than the same stimulus in the euro area. This difference is due to the more rapid adjustment of employment in the US and a weaker and less persistent wage-price spiral. As a result US monetary authorities can start easing monetary policy from as early as year 3, while the policy-controlled interest rate in the euro area stays well above the baseline level during the whole simulation period.

\subsubsection{Permanent ex ante balanced-budget reduction in income taxes by $1 \%$ of GDP in the euro area (accompanied by a reduction in non-wage government consumption)}

In this scenario (shown in Table 3.6) the income tax rates are kept exogenous and have been reduced over the entire simulation horizon so that tax revenues initially fall by $1 \%$ of GDP. Fiscal solvency is assured because government expenditures are cut simultaneously by an equal amount (ex ante budget neutrality). In the first two years the immediate negative effects of the spending cuts prevail, causing real GDP to end up below the baseline level. Higher unemployment and lower income tax rates feed through into lower wage demands and, therefore, into lower inflation. As from year 3 the positive impact on real GDP prevails. Lower interest rates stimulate investment, while tax cuts boost purchasing power and private consumption. In the wake of lower interest payments and wage payments to civil servants and higher indirect tax revenues, the government financial balance gradually further improves and the debt ratio falls, in spite of the adverse denominator effect of a lower nominal GDP.

\subsubsection{Permanent increase in indirect taxation in the euro area equal to $1 \%$ of GDP}

In the design of this scenario it has been assumed that the monetary authorities do not counteract the initial and immediate effects of the increase in indirect taxation (VAT and excise duties) on inflation. For this reason, the Taylor rule is switched off during the first year of the simulation. Thereafter the monetary policy rule is switched on again so that second-order and other effects on inflation feed through in the policy-controlled interest rate. According to Table 3.7, the increase 
in indirect taxation translates immediately into an increase in inflation of 1.4 percentage points. During the whole of the simulation period, real disposable income and private consumption remain below their baseline levels. This scenario further illustrates the strong wage-price spiral in EUROMON, which adds to the persistence of inflation. Owing to the persistence of inflation, the monetary authorities respond as from year 2 by raising interest rates. This leads to a reduction in business investment. Eventually after 6 years, real GDP is $0.6 \%$ below baseline, whereas consumer prices are almost $3.5 \%$ above baseline.

\subsubsection{Increase in oil prices by $\mathbf{2 5 \%}$ over 8 quarters}

Table 3.8a presents the results for the euro area, Table 3.8b for the US. More expensive oil affects the economies in the first instance through higher import prices of oil and oil-related products. In the case of the individual euro countries, energy imports, of which oil products are an important component, have a slightly smaller weight in total imports than is the case in the US. As a reflection of this, import prices in the US increase by $2.3 \%$ in year 2, compared with an average increase of $1.6 \%$ for the euro countries. Higher import prices feed through to a higher domestic price level, a process which evolves faster in the US than in the euro area. The monetary authorities raise interest rates in order to curb the inflationary effects and this adds to the downward pressure on spending and real GDP. With regard to wage growth, it is assumed that higher oil prices were not anticipated, so that they translate into higher wages only in the second year. When the oil price shock comes to an end in year 3, the US economy recovers relatively quickly, partly due to lower interest rates in line with lower inflation levels. Conversely, in the euro area, inflation stabilises and real GDP remains below baseline for some time.

\subsubsection{Reduction in domestic spending in the US, the UK and Japan over 8 quarters}

In this scenario private consumption and business investment are reduced by twice the standard error of the estimated equations. Negative shocks of this size are not very common, but certainly not impossible. The shock differs for each country and for each spending category, thereby underlining the fact that the typical spending shock is by no means a uniform one. The simulation assumes that the major economies outside the euro area are faced with a sudden exogenous fall in demand over two years ('feel bad' factor). Table 3.9a shows the results for the euro area and Table $3.9 \mathrm{~b}$ those for the US. From the latter table it follows that investment in the US declines by $2.7 \%$ and consumption by $1.1 \%$. This negative demand shock translates into a reduction in real GDP in the first year for the US, Japan and the UK relative to their baseline levels of $1.1 \%, 1.5 \%$ and $1.6 \%$, respectively. As a consequence of this, world demand for euro area exports declines, so 
that in year 2 and 3 real GDP in the euro area is $0.2 \%$ below the base level. Supported by the recovery in domestic spending in the US, the UK and Japan in the years after the shock, the volume of world trade gradually returns back to its original level. Overall, it may be concluded from these results that the impact on the euro area economy of a negative demand shock outside the euro area is fairly modest. However, it should also be noted that in the current simulation international spillovers relate almost exclusively to the trade channel, while interest rate spillovers are small. Moreover, confidence effects, which are perhaps more important in practice, have been disregarded altogether. For this reason, share prices have been kept constant over the whole period in this simulation. However, if required it is possible to combine the results of the present scenario with those of a scenario that relates to a fall in share prices (see Tables $3.12 \mathrm{a}$ to $3.12 \mathrm{~d}$ inclusive).

\subsubsection{Autonomous increase in inflation in the euro area by 1 percentage point over 4 quarters}

Annual inflation is shocked by 1 percentage point over 4 quarters. Table 3.10 reports on the results. The monetary authorities react by raising short-term interest rates immediately. Due to inflation persistence and price-wage spillovers, the inflation rate remains above its baseline level during year 2 and 3 by about 0.3 percentage points. Private consumption and investment are down because real personal disposable income is lower and interest rates are higher. Output and employment fall below their baseline levels. In the medium term inflation is back to base and monetary policy is relaxed. As a result the economy gradually recovers.

\subsubsection{Reduction in house prices by $10 \%$ over 8 quarters}

In this scenario house prices are reduced by $10 \%$ over 8 quarters and. Table $3.11 \mathrm{a}$ and Table $3.11 \mathrm{~b}$ relate to a house price shock in the euro area and the US, respectively. The value of home ownership is an important component of households' total net wealth and, therefore, an increase in house prices leads to an increase in private consumption. For most euro area countries, however, including Germany and France, the estimated or calibrated long-term wealth elasticity of consumption is fairly low (in the order of 0.05 ). For this reason, the reduction in consumption in the euro area as a result of the house price shock is not very large (maximum effect is $-0.25 \%$ ). Once again, it should be noted that this disregards additional effects such as confidence effects and effects related to changes in the withdrawal of home equity. Results in the US are about twice as large as in the euro area. 


\subsubsection{Worldwide fall in share prices by $25 \%$ over 8 quarters}

The reported effects of a world wide fall in share prices relate to three different settings. First, we focus on the results of a worldwide fall in share prices alone (Tables 3.12a and 3.12b). Second, it is assumed that the fall in share prices is attended by an increase in the cost of external financing (Tables $3.12 \mathrm{c}$ and $3.12 \mathrm{~d}$ ). Third, in addition to this it is further assumed that consumer confidence worsens (Table 3,12e and 3,12f). For all three scenarios, results are reported for both the euro area and the US. In order to emphasise the global nature of the equity price shock a uniform timepath for share prices has been postulated. Share prices are treated as exogenous over the whole of the simulation period. In the first 8 quarters they are $25 \%$ below their baseline levels. Subsequently they revert to the starting position in two years time, while as from year 5 they remain at their baseline levels. The uniform design of the simulation enhances the comparability of the results.

\section{Table $3.12 a-3.12 b$}

This scenario focuses on the impact of $25 \%$ lower share prices alone, disregarding additional effects. The fall in share prices reduces the net wealth of households and therefore affects consumption. There are no direct effects on other spending categories. As the wealth elasticity of consumption is stronger in the US (0.2) than in the euro area (0.05), the macroeconomic effects in the US are significantly larger. In the US, consumption falls by a maximum of $2.7 \%$, compared with only $0.5 \%$ in the euro area. The maximum impact on real GDP is $-1.8 \%$ in the US versus $-0.5 \%$ in the euro area.

\section{Tables $3.12 c-3.12 d$}

Here, it is assumed that the drop in share prices is accompanied by a 1 percentage point increase in the external finance premium for businesses. This channel is not captured in EUROMON's non-residential investment equations, mainly because it is difficult to quantify empirically. Lower share prices make it more difficult to finance new investment, for example, because bank loans become more expensive as a result of the lower value of the firms' assets (collateral). In fact it is assumed that the user cost of capital is raised by 1 percentage point over two years. In this setting, business investment suffers much more from the drop in share prices. In the US, the maximum impact on real GDP now reaches $-2.8 \%$, while in the euro area the maximum effect on output is $1.2 \%$. 


\section{Tables $3.12 e-3.12 f$}

Now, we also add the effects of a reduction in consumer confidence, which is attended by an additional negative shock to private consumption of twice the standard error of the relevant estimated equations, sustained for eight quarters. For the euro area and the US, this amounts to an additional reduction in consumption by $1.4 \%$ and $1.1 \%$, respectively. It will come as no surprise that the overall impact on real GDP in this extended scenario is larger than in the previous one. In the US, real GDP drops $3.2 \%$ below its baseline level, whereas in the euro area the maximum reduction relative to the baseline level is $2.0 \%$.

\subsubsection{Autonomous increase in the wage level by $1 \%$ over 4 quarters}

Two versions of this scenario are shown. In the first scenario we assume a uniform wage shock in all euro area countries. The second scenario focuses on the results of a German wage shock only.

\section{Autonomous increase in the wage level in the euro area by $1 \%$ over 4 quarters}

The monetary authorities raise the policy-controlled interest rate in order to contain inflation (Table 3.13a). On balance higher interest rates and reduced profitability and competitiveness drive real GDP slightly below baseline. Increased real labour costs further add to the reduction in employment. In the medium term, lower inflation leads to lower interest rates, as a result of which the economy recovers slowly. Due to the persistence of the wage-price spiral, in year 6 wages and prices are still about $0.8 \%$ above their baseline levels.

\section{Autonomous increase in the wage level in Germany by $1 \%$ over 4 quarters}

The effects of a German wage shock on the euro area economy are qualitatively similar to those of a wage shock throughout the euro area as a whole. The size of the effects is, of course, smaller. The monetary authorities now raise interest rates much less sharply, because only German inflation is higher. For the euro area as a whole, the higher interest rates lead to a modest reduction in real output levels (Table 3.13b). In Germany itself private consumption benefits from higher real wages whereas the initial reduction in profitability and competitiveness is not strong enough to counterbalance the positive impact of higher consumption on real GDP (Table 3.13c). In the longer run, however, Germany prices itself out of the market relative to its competitors, and hence exports decline and imports increase. 


\subsubsection{Permanent reduction in the supply of labour in the euro area by $1 \%$}

The reduction in the supply of labour, for example because of ageing, leads to a lower unemployment rate and a lower potential output (Table 3.14). It induces upward pressures on real wages, causing employment to fall. Initially, the output gap widens due to the lower potential output. The central bank responds by raising interest rates, which reduces spending. In year 2 interest rates continue to rise because higher wage growth translates into higher inflation. A process starts whereby employment adjusts to the lower supply of labour through lower output and higher real product wages. In year 6 real GDP is $1.3 \%$ below its baseline level, while the unemployment rate is now 0.2 percentage points above its baseline level. 
Tables with simulation results 
Table 3.1a

Reduction in the policy-controlled interest rate in the euro area by 1 percentage point over 8 quarters (response of long-term interest rates according to backward looking term structure)

Cumulated effects in percentages, unless stated otherwise

\section{Euro Area}

Effects

Real gross domestic product (GDP)

Private consumption

Business investment

Housing investment

Exports

Imports

Output gap

Business employment

Unemployment (\% of labour force)

Labour productivity per person

Compensation per employee

Unit labour cost

Private consumption deflator

Export deflator

Import deflator

GDP deflator

Inflation (private consumption deflator)

Cash flow

Personal disposable income

Trade balance (\% GDP)

Government debt (\% GDP)

Government financial balance (\% GDP)

Short-term interest rate (percentage points)

Long-term interest rate (percentage points)

Exchange rate (euro per US\$)*

Share price index

House price index

M3

Bank loans

Net wealth private sector

Effective exchange rate **

World trade volume

Weighted export price

Weighted import price

\begin{tabular}{|c|c|c|c|c|c|}
\hline Year 1 & $\underline{\text { Year } 2}$ & Year 3 & Year 4 & Year 5 & Year 6 \\
\hline 0.17 & 0.55 & 0.61 & 0.35 & 0.20 & 0.09 \\
\hline 0.09 & 0.49 & 0.72 & 0.46 & 0.30 & 0.21 \\
\hline 0.60 & 2.05 & 2.43 & 1.40 & 0.60 & 0.09 \\
\hline 0.22 & 0.97 & 1.61 & 1.45 & 1.00 & 0.55 \\
\hline 0.08 & 0.24 & 0.39 & 0.56 & 0.58 & 0.48 \\
\hline 0.05 & 0.46 & 1.08 & 1.20 & 0.97 & 0.72 \\
\hline 0.20 & 0.56 & 0.48 & 0.12 & -0.07 & -0.18 \\
\hline 0.03 & 0.19 & 0.37 & 0.36 & 0.24 & 0.07 \\
\hline-0.02 & -0.15 & -0.28 & -0.27 & -0.18 & -0.05 \\
\hline 0.16 & 0.40 & 0.26 & -0.03 & -0.06 & -0.01 \\
\hline 0.04 & 0.32 & 0.86 & 1.34 & 1.74 & 2.05 \\
\hline-0.12 & -0.09 & 0.57 & 1.33 & 1.76 & 2.03 \\
\hline 0.02 & 0.16 & 0.51 & 1.01 & 1.51 & 1.94 \\
\hline 0.07 & 0.15 & 0.16 & 0.34 & 0.70 & 1.10 \\
\hline 0.18 & 0.32 & 0.07 & -0.09 & 0.01 & 0.23 \\
\hline 0.01 & 0.12 & 0.43 & 0.89 & 1.38 & 1.81 \\
\hline 0.02 & 0.14 & 0.35 & 0.50 & 0.50 & 0.41 \\
\hline 0.36 & 0.93 & 0.88 & 0.75 & 1.11 & 1.57 \\
\hline 0.19 & 0.90 & 1.49 & 1.69 & 2.02 & 2.27 \\
\hline-0.02 & -0.08 & -0.13 & 0.01 & 0.18 & 0.30 \\
\hline-0.40 & -1.25 & -1.69 & -1.75 & -1.79 & -1.74 \\
\hline 0.26 & 0.51 & 0.19 & -0.09 & -0.19 & -0.28 \\
\hline-1.00 & -1.00 & 0.89 & 0.84 & 0.69 & 0.49 \\
\hline-0.85 & -0.94 & 0.64 & 0.74 & 0.68 & 0.51 \\
\hline 1.00 & 1.01 & -0.81 & -0.60 & -0.26 & 0.17 \\
\hline 8.18 & 12.06 & -2.99 & -7.73 & -8.21 & -6.69 \\
\hline 0.45 & 1.87 & 3.05 & 2.82 & 2.20 & 1.69 \\
\hline 0.69 & 1.46 & 0.77 & 0.10 & 0.10 & 0.39 \\
\hline 0.18 & 1.45 & 2.97 & 2.59 & 1.53 & 0.41 \\
\hline-0.19 & -0.80 & -1.42 & -1.48 & -1.12 & -0.48 \\
\hline-0.74 & -0.73 & 0.64 & 0.41 & 0.11 & -0.20 \\
\hline 0.04 & 0.31 & 0.75 & 0.87 & 0.73 & 0.53 \\
\hline 0.48 & 0.51 & -0.32 & -0.11 & 0.23 & 0.63 \\
\hline 0.45 & 0.48 & -0.28 & -0.08 & 0.25 & 0.65 \\
\hline
\end{tabular}

A: Absolute difference from base level

$P$ : Percentage difference from base level

* (+) reflects a depreciation of the euro

** (+) reflects an appreciation 
Table 3.1b

Reduction in the policy-controlled interest rate in the euro area by 1 percentage point over 8 quarters (response of long-term interest rates according to backward looking term structure) Cumulated effects in percentages, unless stated otherwise

\begin{tabular}{|c|c|c|c|c|c|c|}
\hline Effects & $\underline{\text { Year } 1}$ & $\underline{\text { Year } 2}$ & $\underline{\text { Year } 3}$ & $\underline{\text { Year } 4}$ & $\underline{\text { Year } 5}$ & Year 6 \\
\hline Real gross domestic product (GDP) & -0.01 & -0.01 & 0.02 & 0.06 & 0.07 & 0.05 \\
\hline Private consumption & 0.00 & 0.00 & 0.01 & 0.01 & 0.00 & -0.03 \\
\hline Business investment & -0.01 & -0.01 & 0.06 & 0.14 & 0.13 & 0.05 \\
\hline Housing investment & 0.00 & 0.01 & 0.01 & -0.01 & -0.03 & -0.05 \\
\hline Exports & -0.03 & -0.02 & 0.20 & 0.46 & 0.53 & 0.51 \\
\hline Imports & 0.00 & 0.03 & 0.12 & 0.16 & 0.10 & 0.00 \\
\hline Output gap & -0.01 & -0.01 & 0.03 & 0.07 & 0.07 & 0.05 \\
\hline Business employment & 0.00 & -0.01 & 0.01 & 0.04 & 0.06 & 0.05 \\
\hline Unemployment ( $\%$ of labour force) & 0.00 & 0.01 & -0.01 & -0.03 & -0.05 & -0.04 \\
\hline Labour productivity per person & 0.00 & 0.00 & 0.02 & 0.03 & 0.02 & 0.00 \\
\hline Compensation per employee & 0.00 & -0.01 & -0.01 & 0.00 & 0.02 & 0.06 \\
\hline Unit labour cost & 0.00 & -0.01 & -0.03 & -0.03 & 0.01 & 0.06 \\
\hline Private consumption deflator & 0.00 & -0.01 & -0.02 & -0.02 & 0.00 & 0.04 \\
\hline Export deflator & -0.03 & -0.09 & -0.06 & 0.02 & 0.08 & 0.14 \\
\hline Import deflator & -0.03 & -0.11 & -0.12 & -0.01 & 0.09 & 0.16 \\
\hline GDP deflator & 0.00 & 0.00 & -0.01 & -0.02 & -0.01 & 0.03 \\
\hline Inflation (private consumption deflator) & 0.00 & 0.00 & -0.01 & 0.00 & 0.02 & 0.04 \\
\hline Cash flow & -0.01 & -0.01 & 0.03 & 0.07 & 0.06 & 0.05 \\
\hline Personal disposable income & 0.00 & 0.00 & 0.00 & 0.01 & 0.03 & 0.06 \\
\hline Trade balance (\% GDP) & 0.00 & 0.00 & 0.02 & 0.03 & 0.03 & 0.03 \\
\hline Government debt (\% GDP) & 0.00 & 0.01 & -0.01 & -0.05 & -0.07 & -0.06 \\
\hline Government financial balance ( $\%$ GDP) & 0.00 & 0.00 & 0.01 & 0.01 & 0.00 & -0.01 \\
\hline Short-term interest rate (percentage points) & -0.01 & -0.01 & 0.01 & 0.05 & 0.08 & 0.09 \\
\hline Long-term interest rate (percentage points) & 0.00 & -0.01 & 0.00 & 0.04 & 0.07 & 0.08 \\
\hline Exchange rate (US\$ per euro)* & -0.99 & -1.00 & 0.82 & 0.60 & 0.26 & -0.17 \\
\hline Share price index & 0.02 & 0.08 & 0.03 & -0.26 & -0.55 & -0.72 \\
\hline House price index & 0.00 & 0.00 & -0.01 & -0.04 & -0.05 & -0.01 \\
\hline M3 & 0.00 & 0.00 & -0.02 & -0.03 & -0.03 & 0.00 \\
\hline Bank loans & 0.00 & 0.00 & 0.03 & 0.05 & -0.01 & -0.16 \\
\hline Net wealth private sector & 0.00 & 0.00 & 0.03 & 0.07 & 0.12 & 0.24 \\
\hline Effective exchange rate ** & 0.40 & 0.41 & -0.31 & -0.24 & -0.13 & 0.03 \\
\hline World trade volume & 0.02 & 0.23 & 0.54 & 0.60 & 0.48 & 0.34 \\
\hline Weighted export price & -0.38 & -0.37 & 0.36 & 0.36 & 0.37 & 0.36 \\
\hline Weighted import price & -0.43 & -0.42 & 0.42 & 0.42 & 0.43 & 0.40 \\
\hline
\end{tabular}

A: Absolute difference from base level

$P$ : Percentage difference from base level

* $(+)$ reflects a depreciation of the US\$

** (+) reflects an appreciation 
Table 3.1c

Reduction in the policy-controlled interest rate in the euro area by 1 percentage point over $\mathbf{8}$ quarters (Euro Area long-term interest rates respond in line with expectation hypothesis and exchange rates in line with uncovered interest rate parity)

Cumulated effects in percentages, unless stated otherwise

Euro Area

Effects

Real gross domestic product (GDP)

Private consumption

Business investment

Housing investment

Exports

Imports

Output gap

Business employment

Unemployment (\% of labour force)

Labour productivity per person

Compensation per employee

Unit labour cost

Private consumption deflator

Export deflator

Import deflator

GDP deflator

Inflation (private consumption deflator)

Cash flow

Personal disposable income

Trade balance (\% GDP)

Government debt (\% GDP)

Government financial balance (\% GDP)

Short-term interest rate (percentage points)

Long-term interest rate (percentage points)

Exchange rate (euro per US\$)*

Share price index

House price index

M3

Bank loans

Net wealth private sector

\begin{tabular}{|c|c|c|c|c|c|}
\hline Year 1 & Year 2 & Year 3 & Year 4 & Year 5 & Year 6 \\
\hline 0.12 & 0.24 & 0.13 & -0.03 & -0.06 & -0.06 \\
\hline 0.03 & 0.13 & 0.11 & -0.08 & -0.11 & -0.11 \\
\hline 0.37 & 1.10 & 1.01 & 0.36 & 0.10 & 0.05 \\
\hline 0.05 & 0.21 & 0.19 & -0.08 & -0.23 & -0.24 \\
\hline 0.14 & 0.20 & 0.14 & 0.15 & 0.10 & 0.02 \\
\hline 0.02 & 0.22 & 0.40 & 0.27 & 0.09 & -0.02 \\
\hline 0.14 & 0.25 & 0.06 & -0.14 & -0.17 & -0.15 \\
\hline 0.03 & 0.11 & 0.15 & 0.07 & -0.02 & -0.08 \\
\hline-0.02 & -0.08 & -0.12 & -0.06 & 0.01 & 0.06 \\
\hline 0.11 & 0.15 & -0.02 & -0.12 & -0.06 & 0.00 \\
\hline 0.04 & 0.24 & 0.48 & 0.57 & 0.60 & 0.58 \\
\hline-0.07 & 0.09 & 0.49 & 0.68 & 0.65 & 0.57 \\
\hline 0.03 & 0.16 & 0.35 & 0.51 & 0.61 & 0.64 \\
\hline 0.12 & 0.17 & 0.11 & 0.19 & 0.34 & 0.44 \\
\hline 0.31 & 0.35 & -0.01 & -0.12 & -0.04 & 0.07 \\
\hline 0.02 & 0.13 & 0.31 & 0.47 & 0.58 & 0.62 \\
\hline 0.03 & 0.13 & 0.19 & 0.16 & 0.09 & 0.03 \\
\hline 0.26 & 0.46 & 0.26 & 0.22 & 0.43 & 0.58 \\
\hline 0.06 & 0.34 & 0.53 & 0.55 & 0.59 & 0.56 \\
\hline-0.02 & -0.03 & -0.02 & 0.08 & 0.14 & 0.15 \\
\hline-0.27 & -0.69 & -0.67 & -0.48 & -0.37 & -0.28 \\
\hline 0.17 & 0.25 & -0.06 & -0.19 & -0.17 & -0.12 \\
\hline-1.00 & -1.00 & 0.33 & 0.14 & 0.02 & -0.07 \\
\hline-0.17 & -0.06 & 0.70 & 0.32 & 0.11 & -0.02 \\
\hline 1.63 & 0.63 & -0.95 & -0.58 & -0.26 & -0.03 \\
\hline 1.52 & 1.12 & -6.40 & -4.64 & -2.12 & -0.05 \\
\hline 0.12 & 0.49 & 0.55 & 0.18 & 0.06 & 0.19 \\
\hline-0.01 & -0.16 & -0.80 & -0.75 & -0.33 & 0.10 \\
\hline 0.10 & 0.76 & 1.36 & 0.90 & 0.44 & 0.20 \\
\hline-0.13 & -0.46 & -0.60 & -0.34 & 0.05 & 0.42 \\
\hline-1.20 & -0.44 & 0.74 & 0.38 & 0.12 & -0.03 \\
\hline 0.02 & 0.17 & 0.33 & 0.27 & 0.13 & 0.02 \\
\hline 0.78 & 0.33 & -0.40 & -0.16 & 0.06 & 0.22 \\
\hline 0.73 & 0.32 & -0.37 & -0.14 & 0.07 & 0.23 \\
\hline
\end{tabular}

exchange rate

World trade volume

Weighted export price

Weighted import price

0.73

0.32

$-0.37$

$-0.14$

A: Absolute difference from base leve

$P$ : Percentage difference from base level

* $(+)$ reflects a depreciation of the euro

** $(+)$ reflects an appreciation 
Table 3.1d

Reduction in the policy-controlled interest rate in the euro area by 1 percentage point over 8 quarters

(Euro Area long-term interest rates respond in line with expectation hypothesis and exchange rates

in line with uncovered interest rate parity)

Cumulated effects in percentages, unless stated otherwise

\section{United States}

Effects

Real gross domestic product (GDP)

Private consumption

Business investment

Housing investment

Exports

Imports

Output gap

Business employment

Unemployment (\% of labour force)

Labour productivity per person

Compensation per employee

Unit labour cost

Private consumption deflator

Export deflator

Import deflator

GDP deflator

Inflation (private consumption deflator)

Cash flow

Personal disposable income

Trade balance ( $\%$ GDP)

Government debt (\% GDP)

Government financial balance (\% GDP)

\begin{tabular}{rrrrrrr} 
Year 1 & Year 2 & Year 3 & Year 4 & Year 5 & Year 6 & \\
\cline { 3 - 4 }-0.01 & -0.02 & 0.01 & 0.04 & 0.04 & 0.03 & $\mathrm{P}$ \\
0.00 & 0.01 & 0.02 & 0.02 & 0.01 & -0.01 & $\mathrm{P}$ \\
-0.02 & -0.03 & 0.03 & 0.10 & 0.09 & 0.03 & $\mathrm{P}$ \\
0.00 & 0.01 & 0.02 & 0.00 & -0.02 & -0.03 & $\mathrm{P}$ \\
-0.06 & -0.08 & 0.07 & 0.20 & 0.20 & 0.17 & $\mathrm{P}$ \\
0.00 & 0.05 & 0.12 & 0.11 & 0.03 & -0.05 & $\mathrm{P}$ \\
& & & & & & \\
-0.01 & -0.02 & 0.01 & 0.04 & 0.04 & 0.03 & $\mathrm{~A}$ \\
-0.01 & -0.02 & 0.00 & 0.02 & 0.04 & 0.03 & $\mathrm{P}$ \\
0.01 & 0.01 & 0.00 & -0.02 & -0.03 & -0.02 & $\mathrm{~A}$ \\
-0.01 & 0.00 & 0.01 & 0.02 & 0.01 & 0.00 & $\mathrm{P}$ \\
& & & & & & \\
0.00 & -0.01 & -0.03 & -0.03 & -0.02 & 0.00 & $\mathrm{P}$ \\
0.00 & -0.01 & -0.04 & -0.05 & -0.03 & 0.00 & $\mathrm{P}$ \\
0.00 & -0.01 & -0.03 & -0.04 & -0.03 & -0.01 & $\mathrm{P}$ \\
-0.06 & -0.12 & -0.05 & 0.01 & 0.04 & 0.06 & $\mathrm{P}$ \\
-0.06 & -0.16 & -0.12 & -0.01 & 0.08 & 0.12 & $\mathrm{P}$ \\
0.00 & -0.01 & -0.02 & -0.04 & -0.04 & -0.02 & $\mathrm{P}$ \\
0.00 & -0.01 & -0.02 & -0.01 & 0.01 & 0.02 & $\mathrm{~A}$ \\
& & & & & & \\
-0.02 & -0.03 & 0.01 & 0.02 & 0.01 & -0.01 & $\mathrm{P}$ \\
0.00 & -0.01 & -0.02 & -0.03 & -0.02 & 0.00 & $\mathrm{P}$ \\
& & & & & & \\
-0.01 & 0.00 & 0.00 & 0.00 & 0.01 & 0.01 & $\mathrm{~A}$ \\
0.01 & 0.02 & 0.00 & -0.02 & -0.03 & -0.03 & $\mathrm{~A}$ \\
0.00 & 0.00 & 0.01 & 0.02 & 0.01 & -0.01 & $\mathrm{~A}$ \\
0.01 & 0.12 & 0.22 & 0.16 & 0.07 & 0.00 & $\mathrm{P}$ \\
-0.61 & -0.21 & 0.41 & 0.31 & 0.24 & 0.18 & $\mathrm{P}$ \\
-0.70 & -0.25 & 0.47 & 0.36 & 0.28 & 0.20 & $\mathrm{P}$ \\
-0.01 & -0.03 & -0.02 & 0.02 & 0.04 & 0.05 & $\mathrm{~A}$ \\
-1.60 & -0.02 & -0.02 & 0.01 & 0.04 & 0.04 & $\mathrm{~A}$ \\
0.04 & 0.17 & 0.21 & -0.02 & -0.25 & -0.38 & $\mathrm{P}$ \\
0.00 & 0.01 & -0.01 & -0.05 & -0.06 & -0.05 & $\mathrm{P}$ \\
0.00 & -0.01 & -0.03 & -0.05 & -0.06 & -0.05 & $\mathrm{P}$ \\
0.00 & -0.00 & 0.05 & 0.11 & 0.12 & 0.04 & $\mathrm{P}$ \\
& & -0.02 & -0.05 & -0.07 & -0.05 & $\mathrm{P}$ \\
& & & & & &
\end{tabular}

Short-term interest rate (percentage points

Long-term interest rate (percentage points)

Exchange rate (US\$ per euro)*

Share price index

House price index

M3

Bank loans

Net wealth private sector

Effective exchange rate **

World trade volume

Weighted export price

Weighted import price

A: Absolute difference from base level

$P$ : Percentage difference from base level

* $(+)$ reflects a depreciation of the US\$

** (+) reflects an appreciation 
Table 3.1e

Reduction in the policy-controlled interest rate in the United States by 1 percentage point over 8 quarters (response of long-term interest rates according to backward looking term structure)

Cumulated effects in percentages, unless stated otherwise

Euro Area

Effects

Real gross domestic product (GDP)

Private consumption

Business investment

Housing investment

Exports

Imports

Output gap

Business employment

Unemployment (\% of labour force)

Labour productivity per person

Compensation per employee

Unit labour cost

Private consumption deflator

Export deflator

Import deflator

GDP deflator

Inflation (private consumption deflator)

Cash flow

Personal disposable income

Trade balance (\% GDP)

Government debt (\% GDP)

Government financial balance (\% GDP)

Short-term interest rate (percentage points)

Long-term interest rate (percentage points)

Exchange rate (euro per US\$)*

Share price index

House price index

M3

Bank loans

Net wealth private sector

Effective exchange rate **

World trade volume

Weighted export price

Weighted import price

\begin{tabular}{|c|c|c|c|c|c|}
\hline Year 1 & Year 2 & Year 3 & $\underline{\text { Year } 4}$ & $\underline{\text { Year } 5}$ & Year 6 \\
\hline-0.01 & 0.02 & 0.10 & 0.08 & 0.05 & 0.02 \\
\hline 0.00 & 0.02 & 0.03 & 0.02 & -0.01 & -0.02 \\
\hline 0.00 & 0.06 & 0.14 & 0.08 & 0.00 & -0.07 \\
\hline 0.00 & 0.01 & 0.01 & -0.02 & -0.07 & -0.11 \\
\hline-0.02 & 0.06 & 0.26 & 0.30 & 0.26 & 0.24 \\
\hline 0.00 & 0.04 & 0.13 & 0.18 & 0.15 & 0.12 \\
\hline-0.01 & 0.03 & 0.11 & 0.09 & 0.04 & 0.02 \\
\hline 0.00 & 0.00 & 0.02 & 0.06 & 0.07 & 0.04 \\
\hline 0.00 & 0.00 & -0.02 & -0.04 & -0.05 & -0.03 \\
\hline-0.01 & 0.03 & 0.08 & 0.03 & -0.02 & -0.03 \\
\hline-0.01 & -0.05 & -0.05 & 0.02 & 0.10 & 0.16 \\
\hline 0.00 & -0.08 & -0.14 & -0.01 & 0.11 & 0.18 \\
\hline-0.01 & -0.06 & -0.08 & -0.02 & 0.06 & 0.12 \\
\hline-0.03 & -0.06 & -0.03 & 0.01 & 0.05 & 0.12 \\
\hline-0.15 & -0.24 & 0.04 & 0.09 & 0.00 & -0.07 \\
\hline-0.01 & -0.05 & -0.08 & -0.03 & 0.04 & 0.10 \\
\hline-0.01 & -0.05 & -0.02 & 0.06 & 0.07 & 0.07 \\
\hline-0.03 & 0.00 & 0.10 & 0.05 & 0.03 & 0.06 \\
\hline-0.01 & -0.03 & -0.02 & 0.03 & 0.08 & 0.13 \\
\hline 0.03 & 0.06 & 0.03 & 0.03 & 0.08 & 0.11 \\
\hline 0.01 & 0.00 & -0.04 & -0.04 & -0.03 & -0.01 \\
\hline 0.00 & 0.02 & 0.01 & -0.02 & -0.04 & -0.05 \\
\hline-0.03 & -0.05 & 0.06 & 0.16 & 0.14 & 0.11 \\
\hline-0.02 & -0.05 & 0.04 & 0.14 & 0.14 & 0.12 \\
\hline-0.97 & -0.96 & 0.91 & 0.16 & -0.40 & -0.77 \\
\hline 0.18 & 0.50 & -0.19 & -1.45 & -1.74 & -1.62 \\
\hline-0.01 & -0.03 & -0.07 & -0.12 & -0.16 & -0.14 \\
\hline 0.00 & -0.01 & -0.05 & -0.13 & -0.17 & -0.15 \\
\hline 0.00 & 0.02 & 0.09 & 0.04 & -0.17 & -0.42 \\
\hline 0.02 & 0.07 & 0.11 & 0.15 & 0.27 & 0.46 \\
\hline 0.26 & 0.25 & -0.26 & -0.08 & 0.05 & 0.15 \\
\hline 0.05 & 0.24 & 0.34 & 0.23 & 0.18 & 0.19 \\
\hline-0.18 & -0.16 & 0.23 & 0.17 & 0.18 & 0.22 \\
\hline-0.17 & -0.16 & 0.22 & 0.16 & 0.18 & 0.21 \\
\hline
\end{tabular}

\footnotetext{
A: Absolute difference from base level

P: Percentage difference from base level

* $(+)$ reflects a depreciation of the euro

** $(+)$ reflects an appreciation
} 
Table 3.1f

Reduction in the policy-controlled interest rate in the United States by 1 percentage point over 8 quarters (response of long-term interest rates according to backward looking term structure)

Cumulated effects in percentages, unless stated otherwise

\begin{tabular}{|c|c|c|c|c|c|c|c|}
\hline \multicolumn{8}{|l|}{ United States } \\
\hline Effects & $\underline{\text { Year } 1}$ & Year 2 & $\underline{\text { Year } 3}$ & $\underline{\text { Year } 4}$ & $\underline{\text { Year } 5}$ & Year 6 & \\
\hline Real gross domestic product (GDP) & 0.45 & 1.18 & 0.84 & 0.17 & -0.11 & -0.14 & $\mathrm{P}$ \\
\hline Private consumption & 0.48 & 1.17 & 0.74 & 0.16 & 0.07 & 0.13 & $\mathrm{P}$ \\
\hline Business investment & 0.94 & 3.03 & 3.03 & 1.03 & -0.03 & -0.19 & $\mathrm{P}$ \\
\hline Housing investment & 0.27 & 1.34 & 1.95 & 1.23 & 0.88 & 0.87 & $\mathrm{P}$ \\
\hline Exports & 0.09 & 0.27 & 0.17 & -0.11 & -0.27 & -0.35 & $\mathrm{P}$ \\
\hline Imports & 0.36 & 1.55 & 1.81 & 0.79 & 0.54 & 0.69 & $\mathrm{P}$ \\
\hline Output gap & 0.48 & 1.17 & 0.67 & -0.12 & -0.42 & -0.42 & A \\
\hline Business employment & 0.24 & 0.75 & 0.74 & 0.27 & -0.06 & -0.18 & $P$ \\
\hline Unemployment ( $\%$ of labour force) & -0.20 & -0.61 & -0.61 & -0.22 & 0.05 & 0.15 & A \\
\hline Labour productivity per person & 0.25 & 0.49 & 0.13 & -0.12 & -0.08 & 0.02 & $\mathrm{P}$ \\
\hline Compensation per employee & 0.07 & 0.45 & 1.02 & 1.38 & 1.63 & 1.75 & $\mathrm{P}$ \\
\hline Unit labour cost & -0.18 & -0.05 & 0.89 & 1.50 & 1.71 & 1.74 & $P$ \\
\hline Private consumption deflator & 0.01 & 0.17 & 0.61 & 1.13 & 1.49 & 1.67 & $P$ \\
\hline Export deflator & 0.09 & 0.29 & 0.45 & 0.79 & 1.25 & 1.55 & $\mathrm{P}$ \\
\hline Import deflator & 0.07 & 0.25 & 0.25 & 0.07 & 0.03 & 0.14 & $P$ \\
\hline GDP deflator & 0.01 & 0.12 & 0.49 & 1.00 & 1.41 & 1.63 & $P$ \\
\hline Inflation (private consumption deflator) & 0.01 & 0.16 & 0.44 & 0.51 & 0.36 & 0.18 & A \\
\hline Cash flow & 0.74 & 1.60 & 0.88 & 0.51 & 0.83 & 1.26 & $\mathrm{P}$ \\
\hline Personal disposable income & 0.28 & 1.09 & 1.66 & 1.83 & 2.09 & 2.15 & $\mathrm{P}$ \\
\hline Trade balance ( $\%$ GDP) & -0.04 & -0.20 & -0.23 & -0.06 & 0.00 & -0.02 & A \\
\hline Government debt (\% GDP) & -0.59 & -1.77 & -2.10 & -1.81 & -1.58 & -1.43 & A \\
\hline Government financial balance (\% GDP) & 0.32 & 0.70 & 0.27 & -0.22 & -0.32 & -0.28 & A \\
\hline Short-term interest rate (percentage points) & -1.00 & -1.00 & 1.05 & 0.55 & 0.13 & -0.10 & A \\
\hline Long-term interest rate (percentage points) & -0.85 & -0.94 & 0.78 & 0.51 & 0.18 & -0.05 & A \\
\hline Exchange rate (US\$ per euro)* & 0.98 & 0.97 & -0.90 & -0.16 & 0.41 & 0.78 & $\mathrm{P}$ \\
\hline Share price index & 5.95 & 8.84 & -3.77 & -4.22 & -1.95 & 0.11 & $P$ \\
\hline House price index & 0.65 & 1.37 & 1.09 & 1.67 & 2.36 & 2.69 & $\mathrm{P}$ \\
\hline M3 & 0.27 & 0.11 & -0.84 & -0.69 & 0.17 & 1.05 & $\mathrm{P}$ \\
\hline Bank loans & 0.28 & 2.00 & 4.42 & 4.35 & 2.94 & 1.79 & $\mathrm{P}$ \\
\hline Net wealth private sector & -0.52 & -2.79 & -5.28 & -5.44 & -4.62 & -3.81 & $\mathrm{P}$ \\
\hline Effective exchange rate ${ }^{* *}$ & -0.97 & -0.97 & 0.90 & 0.17 & -0.39 & -0.75 & $\mathrm{P}$ \\
\hline World trade volume & 0.01 & 0.05 & 0.13 & 0.13 & 0.10 & 0.08 & $P$ \\
\hline Weighted export price & 0.96 & 0.94 & -0.93 & -0.20 & 0.41 & 0.84 & $\mathrm{P}$ \\
\hline Weighted import price & 0.96 & 0.94 & -0.93 & -0.19 & 0.42 & 0.85 & $\mathrm{P}$ \\
\hline
\end{tabular}

A: Absolute difference from base level

P: Percentage difference from base level

* $(+)$ reflects a depreciation of the US\$

** (+) reflects an appreciation 
Table 3.1g

Reduction in the policy-controlled interest rate in the United States by 1 percentage point over 8 quarters (US long-term interest rates respond in line with expectation hypothesis and exchange rates

in line with uncovered interest rate parity)

Cumulated effects in percentages, unless stated otherwise

\begin{tabular}{|c|c|c|c|c|c|c|}
\hline Effects & $\underline{\text { Year } 1}$ & Year 2 & $\underline{\text { Year } 3}$ & $\underline{\text { Year } 4}$ & Year 5 & Year 6 \\
\hline Real gross domestic product (GDP) & -0.04 & 0.01 & 0.08 & 0.06 & 0.04 & 0.02 \\
\hline Private consumption & 0.00 & 0.03 & 0.06 & 0.04 & 0.02 & 0.00 \\
\hline Business investment & -0.03 & 0.05 & 0.14 & 0.09 & 0.03 & -0.03 \\
\hline Housing investment & 0.00 & 0.03 & 0.05 & 0.04 & 0.01 & -0.02 \\
\hline Exports & -0.09 & -0.02 & 0.13 & 0.13 & 0.10 & 0.09 \\
\hline Imports & 0.00 & 0.01 & 0.08 & 0.09 & 0.06 & 0.04 \\
\hline Output gap & -0.05 & 0.01 & 0.09 & 0.06 & 0.03 & 0.01 \\
\hline Business employment & -0.01 & -0.02 & 0.00 & 0.04 & 0.06 & 0.05 \\
\hline Unemployment ( $\%$ of labour force) & 0.01 & 0.02 & 0.00 & -0.03 & -0.04 & -0.03 \\
\hline Labour productivity per person & -0.03 & 0.03 & 0.08 & 0.02 & -0.02 & -0.03 \\
\hline Compensation per employee & -0.02 & -0.11 & -0.13 & -0.08 & -0.03 & 0.03 \\
\hline Unit labour cost & 0.01 & -0.14 & -0.21 & -0.11 & -0.01 & 0.06 \\
\hline Private consumption deflator & -0.03 & -0.11 & -0.15 & -0.11 & -0.05 & 0.01 \\
\hline Export deflator & -0.08 & -0.09 & -0.03 & -0.03 & -0.02 & 0.02 \\
\hline Import deflator & -0.29 & -0.29 & 0.05 & 0.10 & 0.06 & 0.04 \\
\hline GDP deflator & -0.02 & -0.09 & -0.14 & -0.12 & -0.06 & 0.00 \\
\hline Inflation (private consumption deflator) & -0.03 & -0.09 & -0.04 & 0.04 & 0.06 & 0.07 \\
\hline Cash flow & -0.09 & -0.04 & 0.01 & -0.05 & -0.07 & -0.04 \\
\hline Personal disposable income & -0.03 & -0.08 & -0.07 & -0.05 & -0.01 & 0.03 \\
\hline Trade balance ( $\%$ GDP) & 0.04 & 0.04 & 0.00 & -0.02 & 0.00 & 0.02 \\
\hline Government debt (\% GDP) & 0.03 & 0.02 & -0.02 & -0.02 & -0.02 & -0.02 \\
\hline Government financial balance ( $\%$ GDP) & 0.01 & 0.03 & 0.03 & 0.00 & -0.02 & -0.04 \\
\hline Short-term interest rate (percentage points) & -0.08 & -0.13 & 0.01 & 0.11 & 0.11 & 0.11 \\
\hline Long-term interest rate (percentage points) & -0.06 & -0.12 & -0.01 & 0.09 & 0.10 & 0.10 \\
\hline Exchange rate (euro per US $\$)^{*}$ & -1.63 & -0.62 & 0.71 & 0.31 & 0.10 & -0.02 \\
\hline Share price index & 0.45 & 1.15 & 0.41 & -0.82 & -1.28 & -1.42 \\
\hline House price index & -0.01 & -0.02 & -0.03 & -0.09 & -0.14 & -0.16 \\
\hline M3 & 0.01 & 0.03 & 0.00 & -0.08 & -0.13 & -0.14 \\
\hline Bank loans & -0.01 & 0.05 & 0.20 & 0.23 & 0.10 & -0.08 \\
\hline Net wealth private sector & 0.02 & 0.04 & 0.02 & -0.01 & 0.00 & 0.06 \\
\hline Effective exchange rate ** & 0.76 & -0.01 & -0.47 & -0.27 & -0.18 & -0.14 \\
\hline World trade volume & 0.02 & 0.07 & 0.08 & 0.03 & 0.03 & 0.05 \\
\hline Weighted export price & -0.51 & -0.03 & 0.30 & 0.17 & 0.12 & 0.10 \\
\hline Weighted import price & -0.48 & -0.03 & 0.28 & 0.16 & 0.11 & 0.10 \\
\hline
\end{tabular}

A: Absolute difference from base level

$P$ : Percentage difference from base level

* $(+)$ reflects a depreciation of the euro

** $(+)$ reflects an appreciation 
Table 3.1h

Reduction in the policy-controlled interest rate in the United States by 1 percentage point over 8 quarters (US long-term interest rates respond in line with expectation hypothesis and exchange rates

in line with uncovered interest rate parity)

Cumulated effects in percentages, unless stated otherwise

\begin{tabular}{|c|c|c|c|c|c|c|}
\hline Effects & $\underline{\text { Year } 1}$ & $\underline{\text { Year } 2}$ & $\underline{\text { Year } 3}$ & $\underline{\text { Year } 4}$ & $\underline{\text { Year } 5}$ & Year 6 \\
\hline Real gross domestic product (GDP) & 0.14 & 0.32 & 0.05 & -0.10 & -0.10 & -0.06 \\
\hline Private consumption & 0.11 & 0.21 & -0.13 & -0.21 & -0.13 & -0.06 \\
\hline Business investment & 0.34 & 1.02 & 0.71 & 0.09 & -0.02 & 0.09 \\
\hline Housing investment & 0.06 & 0.26 & 0.18 & -0.17 & -0.14 & -0.01 \\
\hline Exports & 0.12 & 0.30 & 0.23 & 0.06 & -0.04 & -0.08 \\
\hline Imports & 0.10 & 0.33 & 0.09 & -0.25 & -0.13 & 0.06 \\
\hline Output gap & 0.15 & 0.32 & 0.00 & -0.18 & -0.18 & -0.13 \\
\hline Business employment & 0.07 & 0.22 & 0.12 & -0.03 & -0.08 & -0.07 \\
\hline Unemployment ( $\%$ of labour force) & -0.06 & -0.18 & -0.10 & 0.03 & 0.06 & 0.06 \\
\hline Labour productivity per person & 0.07 & 0.12 & -0.07 & -0.08 & -0.03 & 0.00 \\
\hline Compensation per employee & 0.02 & 0.13 & 0.27 & 0.31 & 0.33 & 0.33 \\
\hline Unit labour cost & -0.05 & 0.01 & 0.34 & 0.39 & 0.37 & 0.33 \\
\hline Private consumption deflator & 0.00 & 0.06 & 0.19 & 0.31 & 0.35 & 0.34 \\
\hline Export deflator & 0.12 & 0.28 & 0.27 & 0.28 & 0.32 & 0.32 \\
\hline Import deflator & 0.09 & 0.29 & 0.30 & 0.17 & 0.09 & 0.06 \\
\hline GDP deflator & 0.00 & 0.04 & 0.16 & 0.28 & 0.34 & 0.35 \\
\hline Inflation (private consumption deflator) & 0.00 & 0.05 & 0.14 & 0.11 & 0.04 & -0.01 \\
\hline Cash flow & 0.22 & 0.44 & 0.01 & 0.04 & 0.20 & 0.30 \\
\hline Personal disposable income & 0.09 & 0.31 & 0.35 & 0.34 & 0.36 & 0.31 \\
\hline Trade balance ( $\%$ GDP) & 0.00 & -0.03 & -0.01 & 0.04 & 0.03 & 0.00 \\
\hline Government debt (\% GDP) & -0.22 & -0.58 & -0.45 & -0.23 & -0.12 & -0.07 \\
\hline Government financial balance (\% GDP) & 0.14 & 0.23 & -0.06 & -0.20 & -0.15 & -0.08 \\
\hline Short-term interest rate (percentage points) & -1.00 & -1.00 & 0.17 & 0.01 & -0.08 & -0.10 \\
\hline Long-term interest rate (percentage points) & -0.16 & -0.06 & 0.57 & 0.19 & 0.01 & -0.06 \\
\hline Exchange rate (US\$ per euro)* & 1.65 & 0.63 & -0.71 & -0.31 & -0.10 & 0.02 \\
\hline Share price index & 1.12 & 0.72 & -4.22 & -2.07 & -0.51 & 0.27 \\
\hline House price index & 0.14 & 0.23 & -0.05 & 0.23 & 0.44 & 0.48 \\
\hline M3 & -0.16 & -0.74 & -1.44 & -1.24 & -0.74 & -0.33 \\
\hline Bank loans & 0.11 & 0.77 & 1.50 & 1.18 & 0.61 & 0.34 \\
\hline Net wealth private sector & -0.22 & -0.94 & -1.30 & -0.67 & -0.04 & 0.30 \\
\hline Effective exchange rate ** & -1.23 & -0.82 & 0.38 & 0.09 & -0.07 & -0.16 \\
\hline World trade volume & 0.01 & 0.04 & 0.09 & 0.09 & 0.06 & 0.05 \\
\hline Weighted export price & 1.22 & 0.79 & -0.43 & -0.16 & 0.00 & 0.11 \\
\hline Weighted import price & 1.25 & 0.76 & -0.46 & -0.18 & -0.01 & 0.10 \\
\hline
\end{tabular}

A: Absolute difference from base level

$P$ : Percentage difference from base level

* $(+)$ reflects a depreciation of the US\$

** (+) reflects an appreciation 
Table 3.1i

Reduction in the policy-controlled interest rate in the United States by 1 percentage point over 8 quarters (response of long-term interest rates according to empirical equation including

international interest rate spillovers)

Cumulated effects in percentages, unless stated otherwise

\begin{tabular}{|c|c|c|c|c|c|c|}
\hline Effects & $\underline{\text { Year } 1}$ & $\underline{\text { Year } 2}$ & $\underline{\text { Year } 3}$ & $\underline{\text { Year } 4}$ & $\underline{\text { Year } 5}$ & Year 6 \\
\hline Real gross domestic product (GDP) & 0.00 & 0.06 & 0.13 & 0.11 & 0.08 & 0.06 \\
\hline Private consumption & 0.01 & 0.08 & 0.12 & 0.07 & 0.04 & 0.04 \\
\hline Business investment & 0.04 & 0.20 & 0.28 & 0.14 & 0.03 & -0.01 \\
\hline Housing investment & 0.03 & 0.15 & 0.24 & 0.17 & 0.07 & 0.02 \\
\hline Exports & -0.02 & 0.03 & 0.21 & 0.31 & 0.30 & 0.27 \\
\hline Imports & 0.01 & 0.08 & 0.20 & 0.25 & 0.22 & 0.20 \\
\hline Output gap & 0.00 & 0.06 & 0.13 & 0.10 & 0.06 & 0.04 \\
\hline Business employment & 0.00 & 0.01 & 0.04 & 0.08 & 0.08 & 0.06 \\
\hline Unemployment ( $\%$ of labour force) & 0.00 & -0.01 & -0.03 & -0.06 & -0.06 & -0.05 \\
\hline Labour productivity per person & 0.00 & 0.06 & 0.10 & 0.03 & -0.01 & -0.01 \\
\hline Compensation per employee & -0.01 & -0.03 & 0.00 & 0.10 & 0.20 & 0.30 \\
\hline Unit labour cost & -0.01 & -0.09 & -0.10 & 0.06 & 0.20 & 0.30 \\
\hline Private consumption deflator & -0.01 & -0.06 & -0.06 & 0.03 & 0.14 & 0.24 \\
\hline Export deflator & -0.03 & -0.06 & -0.03 & 0.01 & 0.08 & 0.17 \\
\hline Import deflator & -0.15 & -0.25 & 0.00 & 0.10 & 0.04 & -0.02 \\
\hline GDP deflator & -0.01 & -0.05 & -0.06 & 0.01 & 0.12 & 0.22 \\
\hline Inflation (private consumption deflator) & -0.01 & -0.04 & 0.00 & 0.09 & 0.11 & 0.10 \\
\hline Cash flow & 0.00 & 0.06 & 0.12 & 0.09 & 0.12 & 0.19 \\
\hline Personal disposable income & 0.02 & 0.07 & 0.10 & 0.13 & 0.23 & 0.34 \\
\hline Trade balance ( $\%$ GDP) & 0.03 & 0.04 & 0.01 & 0.02 & 0.06 & 0.11 \\
\hline Government debt (\% GDP) & -0.02 & -0.09 & -0.17 & -0.19 & -0.20 & -0.21 \\
\hline Government financial balance (\% GDP) & 0.02 & 0.06 & 0.04 & -0.02 & -0.04 & -0.05 \\
\hline Short-term interest rate (percentage points) & -0.02 & -0.02 & 0.09 & 0.21 & 0.21 & 0.18 \\
\hline Long-term interest rate (percentage points) & -0.16 & -0.20 & 0.11 & 0.19 & 0.16 & 0.08 \\
\hline Exchange rate (euro per US\$)* & -0.98 & -0.99 & 0.73 & 0.32 & -0.15 & -0.57 \\
\hline Share price index & 1.31 & 2.16 & -0.55 & -2.14 & -2.10 & -1.36 \\
\hline House price index & 0.06 & 0.24 & 0.33 & 0.17 & 0.01 & 0.02 \\
\hline M3 & 0.14 & 0.29 & 0.13 & -0.08 & -0.10 & 0.00 \\
\hline Bank loans & 0.01 & 0.13 & 0.30 & 0.21 & -0.07 & -0.37 \\
\hline Net wealth private sector & 0.01 & 0.00 & -0.05 & -0.05 & 0.06 & 0.23 \\
\hline Effective exchange rate ** & 0.26 & 0.26 & -0.20 & -0.09 & 0.02 & 0.13 \\
\hline World trade volume & 0.03 & 0.19 & 0.33 & 0.31 & 0.25 & 0.22 \\
\hline Weighted export price & -0.18 & -0.17 & 0.18 & 0.15 & 0.19 & 0.25 \\
\hline Weighted import price & -0.18 & -0.16 & 0.17 & 0.14 & 0.18 & 0.24 \\
\hline
\end{tabular}

A: Absolute difference from base level

$P$ : Percentage difference from base level

* (+) reflects a depreciation of the euro

** (+) reflects an appreciation 
Table 3.1j

Reduction in the policy-controlled interest rate in the United States by 1 percentage point over 8 quarters (response of long-term interest rates according to empirical equation including

international interest rate spillovers)

Cumulated effects in percentages, unless stated otherwise

\section{United States}

Effects

Real gross domestic product (GDP)

Private consumption

Business investment

Housing investment

Exports

Imports

Output gap

Business employment

Unemployment (\% of labour force)

Labour productivity per person

Compensation per employee

Unit labour cost

Private consumption deflator

Export deflator

Import deflator

GDP deflator

Inflation (private consumption deflator)

Cash flow

Personal disposable income

Trade balance (\% GDP)

Government debt (\% GDP)

Government financial balance (\% GDP)

\begin{tabular}{|c|c|c|c|c|c|}
\hline Year 1 & Year 2 & Year 3 & Year 4 & $\underline{\text { Year } 5}$ & Year 6 \\
\hline 0.23 & 0.72 & 0.80 & 0.43 & 0.08 & -0.15 \\
\hline 0.23 & 0.66 & 0.70 & 0.40 & 0.17 & 0.03 \\
\hline 0.51 & 1.90 & 2.55 & 1.58 & 0.51 & -0.17 \\
\hline 0.13 & 0.71 & 1.29 & 1.26 & 1.08 & 0.86 \\
\hline 0.09 & 0.29 & 0.26 & 0.02 & -0.14 & -0.21 \\
\hline 0.17 & 0.85 & 1.32 & 0.99 & 0.72 & 0.56 \\
\hline 0.25 & 0.72 & 0.71 & 0.23 & -0.18 & -0.40 \\
\hline 0.12 & 0.45 & 0.62 & 0.41 & 0.12 & -0.12 \\
\hline-0.10 & -0.37 & -0.50 & -0.34 & -0.10 & 0.10 \\
\hline 0.13 & 0.31 & 0.22 & 0.03 & -0.06 & -0.06 \\
\hline 0.03 & 0.25 & 0.66 & 1.04 & 1.33 & 1.48 \\
\hline-0.09 & -0.05 & 0.44 & 1.01 & 1.38 & 1.54 \\
\hline 0.01 & 0.09 & 0.37 & 0.78 & 1.15 & 1.38 \\
\hline 0.09 & 0.27 & 0.34 & 0.51 & 0.89 & 1.24 \\
\hline 0.07 & 0.25 & 0.28 & 0.10 & 0.02 & 0.08 \\
\hline 0.00 & 0.07 & 0.30 & 0.68 & 1.06 & 1.33 \\
\hline 0.01 & 0.09 & 0.28 & 0.40 & 0.37 & 0.24 \\
\hline 0.39 & 1.00 & 0.97 & 0.69 & 0.67 & 0.84 \\
\hline 0.15 & 0.63 & 1.18 & 1.49 & 1.74 & 1.81 \\
\hline-0.01 & -0.10 & -0.16 & -0.10 & -0.04 & -0.01 \\
\hline-0.34 & -1.10 & -1.58 & -1.60 & -1.46 & -1.26 \\
\hline 0.20 & 0.45 & 0.28 & -0.01 & -0.18 & -0.26 \\
\hline-1.00 & -1.00 & 0.88 & 0.68 & 0.33 & -0.01 \\
\hline-0.42 & -0.58 & 0.10 & 0.24 & 0.24 & 0.17 \\
\hline 0.99 & 1.00 & -0.72 & -0.32 & 0.15 & 0.58 \\
\hline 2.73 & 5.03 & 0.45 & -1.77 & -2.10 & -1.56 \\
\hline 0.32 & 0.78 & 0.96 & 1.38 & 1.86 & 2.14 \\
\hline-0.01 & -0.31 & -0.66 & -0.40 & 0.16 & 0.74 \\
\hline 0.16 & 1.25 & 3.07 & 3.63 & 2.93 & 1.88 \\
\hline-0.31 & -1.67 & -3.43 & -4.16 & -4.04 & -3.45 \\
\hline-0.98 & -1.01 & 0.72 & 0.34 & -0.13 & -0.57 \\
\hline 0.01 & 0.09 & 0.19 & 0.19 & 0.15 & 0.13 \\
\hline 0.98 & 0.98 & -0.75 & -0.35 & 0.20 & 0.74 \\
\hline 0.97 & 0.97 & -0.75 & -0.34 & 0.20 & 0.73 \\
\hline
\end{tabular}

Short-term interest rate (percentage points)

Long-term interest rate (percentage points)

Exchange rate (US\$ per euro)*

Share price index

House price index

M3

Bank loans

Net wealth private sector

Effective exchange rate **

World trade volume

Weighted export price

Weighted import price

A: Absolute difference from base level

$P$ : Percentage difference from base level

* $(+)$ reflects a depreciation of the US\$

** (+) reflects an appreciation 
Table 3.2a

Worldwide reduction in capital market interest rates by 1 percentage point over 8 quarters Cumulated effects in percentages, unless stated otherwise

\begin{tabular}{|c|c|c|c|c|c|c|}
\hline Effects & $\underline{\text { Year } 1}$ & Year 2 & Year 3 & Year 4 & $\underline{\text { Year } 5}$ & $\underline{\text { Year } 6}$ \\
\hline Real gross domestic product (GDP) & 0.13 & 0.47 & 0.70 & 0.62 & 0.43 & 0.26 \\
\hline Private consumption & 0.10 & 0.51 & 0.81 & 0.76 & 0.59 & 0.44 \\
\hline Business investment & 0.40 & 1.31 & 1.84 & 1.42 & 0.65 & -0.04 \\
\hline Housing investment & 0.26 & 1.09 & 1.95 & 2.11 & 1.65 & 1.00 \\
\hline Exports & 0.02 & 0.23 & 0.64 & 0.99 & 1.11 & 1.06 \\
\hline Imports & 0.05 & 0.40 & 1.03 & 1.49 & 1.52 & 1.32 \\
\hline Output gap & 0.14 & 0.48 & 0.64 & 0.47 & 0.22 & 0.02 \\
\hline Business employment & 0.02 & 0.15 & 0.34 & 0.45 & 0.40 & 0.23 \\
\hline Unemployment ( $\%$ of labour force) & -0.02 & -0.12 & -0.26 & -0.34 & -0.30 & -0.17 \\
\hline Labour productivity per person & 0.12 & 0.36 & 0.40 & 0.18 & 0.02 & -0.01 \\
\hline Compensation per employee & 0.02 & 0.23 & 0.70 & 1.31 & 1.90 & 2.41 \\
\hline Unit labour cost & -0.09 & -0.14 & 0.27 & 1.09 & 1.84 & 2.38 \\
\hline Private consumption deflator & 0.01 & 0.09 & 0.37 & 0.88 & 1.50 & 2.10 \\
\hline Export deflator & 0.00 & 0.02 & 0.10 & 0.30 & 0.65 & 1.13 \\
\hline Import deflator & 0.04 & 0.10 & 0.12 & 0.03 & -0.01 & 0.09 \\
\hline GDP deflator & 0.01 & 0.06 & 0.30 & 0.76 & 1.34 & 1.94 \\
\hline Inflation (private consumption deflator) & 0.01 & 0.08 & 0.28 & 0.51 & 0.62 & 0.59 \\
\hline Cash flow & 0.26 & 0.75 & 1.03 & 1.01 & 1.21 & 1.63 \\
\hline Personal disposable income & 0.24 & 0.89 & 1.48 & 1.83 & 2.27 & 2.71 \\
\hline Trade balance ( $\%$ GDP) & -0.02 & -0.06 & -0.07 & 0.02 & 0.20 & 0.38 \\
\hline Government debt (\% GDP) & -0.23 & -0.81 & -1.45 & -1.85 & -2.08 & -2.13 \\
\hline Government financial balance (\% GDP) & 0.13 & 0.30 & 0.31 & 0.13 & -0.05 & -0.24 \\
\hline Short-term interest rate (percentage points) & 0.12 & 0.48 & 0.90 & 1.11 & 1.09 & 0.90 \\
\hline Long-term interest rate (percentage points) & -1.00 & -1.00 & -0.10 & 0.68 & 0.92 & 0.86 \\
\hline Exchange rate (euro per US\$)* & 0.28 & 0.50 & 0.29 & -0.32 & -0.72 & -0.79 \\
\hline Share price index & 9.90 & 13.09 & 5.01 & -5.57 & -9.69 & -10.00 \\
\hline House price index & 0.52 & 2.02 & 3.52 & 3.77 & 3.06 & 2.19 \\
\hline M3 & 1.09 & 2.27 & 2.31 & 1.28 & 0.62 & 0.44 \\
\hline Bank loans & 0.13 & 0.87 & 1.70 & 1.61 & 0.61 & -0.75 \\
\hline Net wealth private sector & -0.10 & -0.46 & -0.97 & -1.27 & -1.12 & -0.50 \\
\hline Effective exchange rate ** & -0.06 & -0.08 & 0.00 & 0.21 & 0.39 & 0.44 \\
\hline World trade volume & 0.10 & 0.55 & 1.11 & 1.36 & 1.29 & 1.11 \\
\hline Weighted export price & 0.03 & 0.02 & 0.01 & 0.08 & 0.36 & 0.78 \\
\hline Weighted import price & 0.03 & 0.03 & 0.02 & 0.11 & 0.37 & 0.79 \\
\hline
\end{tabular}

A: Absolute difference from base level

P: Percentage difference from base level

* (+) reflects a depreciation of the euro

** $(+)$ reflects an appreciation 


\section{Table 3.2b}

Worldwide reduction in capital market interest rates by 1 percentage point over 8 quarters Cumulated effects in percentages, unless stated otherwise

\section{United States}

Effects

Real gross domestic product (GDP)

Private consumption

Business investment

Housing investment

Exports

Imports

Output gap

Business employment

Unemployment (\% of labour force)

Labour productivity per person

Compensation per employee

Unit labour cost

Private consumption deflator

Export deflator

Import deflator

GDP deflator

Inflation (private consumption deflator)

Cash flow

Personal disposable income

Trade balance (\% GDP)

Government debt (\% GDP)

Government financial balance (\% GDP)

Short-term interest rate (percentage points)

Long-term interest rate (percentage points)

Exchange rate (US\$ per euro)*

Share price index

House price index

M3

Bank loans

Net wealth private sector

Effective exchange rate **

World trade volume

Weighted export price

Weighted import price

\begin{tabular}{|c|c|c|c|c|c|}
\hline Year 1 & Year 2 & Year 3 & Year 4 & Year 5 & Year 6 \\
\hline 0.49 & 1.07 & 1.11 & 0.51 & 0.11 & -0.04 \\
\hline 0.57 & 1.22 & 1.27 & 0.67 & 0.35 & 0.28 \\
\hline 0.92 & 2.44 & 2.83 & 1.36 & 0.07 & -0.43 \\
\hline 0.32 & 1.49 & 2.40 & 2.17 & 1.61 & 1.30 \\
\hline-0.01 & -0.01 & 0.09 & 0.25 & 0.32 & 0.30 \\
\hline 0.42 & 1.62 & 2.32 & 1.76 & 1.21 & 1.04 \\
\hline 0.51 & 1.05 & 0.97 & 0.25 & -0.19 & -0.32 \\
\hline 0.26 & 0.69 & 0.84 & 0.49 & 0.12 & -0.09 \\
\hline-0.21 & -0.56 & -0.69 & -0.40 & -0.10 & 0.07 \\
\hline 0.27 & 0.44 & 0.32 & 0.02 & -0.04 & 0.02 \\
\hline 0.08 & 0.44 & 1.00 & 1.48 & 1.83 & 2.06 \\
\hline-0.19 & 0.00 & 0.68 & 1.46 & 1.87 & 2.04 \\
\hline 0.01 & 0.17 & 0.57 & 1.11 & 1.57 & 1.89 \\
\hline-0.02 & -0.06 & 0.12 & 0.64 & 1.28 & 1.78 \\
\hline-0.01 & -0.10 & -0.22 & -0.23 & -0.09 & 0.16 \\
\hline 0.01 & 0.12 & 0.46 & 0.97 & 1.46 & 1.81 \\
\hline 0.01 & 0.15 & 0.40 & 0.54 & 0.46 & 0.31 \\
\hline 0.79 & 1.40 & 1.32 & 0.83 & 0.97 & 1.38 \\
\hline 0.29 & 1.03 & 1.79 & 2.15 & 2.49 & 2.70 \\
\hline-0.06 & -0.21 & -0.26 & -0.12 & -0.01 & 0.01 \\
\hline-0.54 & -1.47 & -2.18 & -2.25 & -2.16 & -2.04 \\
\hline 0.24 & 0.52 & 0.47 & 0.09 & -0.16 & -0.26 \\
\hline 0.40 & 0.98 & 1.22 & 0.86 & 0.44 & 0.15 \\
\hline-1.00 & -1.00 & -0.08 & 0.38 & 0.30 & 0.13 \\
\hline-0.28 & -0.50 & -0.29 & 0.32 & 0.73 & 0.80 \\
\hline 7.18 & 9.51 & 3.16 & -2.37 & -2.32 & -1.02 \\
\hline 0.77 & 1.46 & 1.78 & 2.09 & 2.68 & 3.10 \\
\hline 0.71 & 1.54 & 1.83 & 1.74 & 2.01 & 2.46 \\
\hline 0.25 & 1.44 & 2.96 & 3.16 & 2.08 & 0.85 \\
\hline-0.44 & -2.34 & -4.90 & -6.27 & -6.25 & -5.62 \\
\hline 0.34 & 0.69 & 0.62 & 0.06 & -0.40 & -0.62 \\
\hline 0.04 & 0.30 & 0.69 & 0.91 & 0.84 & 0.69 \\
\hline-0.33 & -0.67 & -0.56 & 0.13 & 0.82 & 1.33 \\
\hline-0.32 & -0.64 & -0.50 & 0.20 & 0.88 & 1.39 \\
\hline
\end{tabular}

A: Absolute difference from base level

P: Percentage difference from base level

* $(+)$ reflects a depreciation of the US\$

** $(+)$ reflects an appreciation 
Table 3.3a

Permanent appreciation of the effective exchange rate of the US-dollar by $10 \%$ Cumulated effects in percentages, unless stated otherwise

\begin{tabular}{|c|c|c|c|c|c|c|}
\hline Effects & $\underline{\text { Year } 1}$ & Year 2 & Year 3 & Year 4 & $\underline{\text { Year } 5}$ & $\underline{\text { Year } 6}$ \\
\hline Real gross domestic product (GDP) & 0.12 & 0.10 & -0.06 & -0.22 & -0.37 & -0.48 \\
\hline Private consumption & -0.01 & -0.15 & -0.38 & -0.59 & -0.78 & -0.93 \\
\hline Business investment & 0.07 & -0.17 & -0.53 & -0.85 & -1.11 & -1.23 \\
\hline Housing investment & -0.01 & -0.13 & -0.38 & -0.68 & -0.94 & -1.14 \\
\hline Exports & 0.26 & 0.34 & 0.24 & 0.12 & 0.01 & -0.10 \\
\hline Imports & -0.04 & -0.20 & -0.43 & -0.63 & -0.80 & -0.94 \\
\hline Output gap & 0.15 & 0.13 & -0.02 & -0.17 & -0.30 & -0.38 \\
\hline Business employment & 0.03 & 0.12 & 0.14 & 0.06 & -0.10 & -0.25 \\
\hline Unemployment (\% of labour force) & -0.03 & -0.09 & -0.11 & -0.04 & 0.07 & 0.19 \\
\hline Labour productivity per person & 0.10 & -0.02 & -0.21 & -0.30 & -0.31 & -0.27 \\
\hline Compensation per employee & 0.10 & 0.59 & 1.19 & 1.79 & 2.35 & 2.80 \\
\hline Unit labour cost & 0.00 & 0.61 & 1.40 & 2.11 & 2.68 & 3.10 \\
\hline Private consumption deflator & 0.14 & 0.65 & 1.30 & 1.98 & 2.62 & 3.16 \\
\hline Export deflator & 0.25 & 0.57 & 0.93 & 1.38 & 1.85 & 2.28 \\
\hline Import deflator & 1.47 & 2.42 & 2.67 & 2.88 & 3.11 & 3.35 \\
\hline GDP deflator & 0.09 & 0.52 & 1.14 & 1.79 & 2.43 & 2.99 \\
\hline Inflation (private consumption deflator) & 0.14 & 0.51 & 0.64 & 0.67 & 0.63 & 0.52 \\
\hline Cash flow & 0.34 & 0.59 & 0.86 & 1.29 & 1.83 & 2.39 \\
\hline Personal disposable income & 0.12 & 0.46 & 0.84 & 1.24 & 1.59 & 1.86 \\
\hline Trade balance ( $\%$ GDP) & -0.30 & -0.30 & -0.21 & -0.09 & 0.02 & 0.10 \\
\hline Government debt (\% GDP) & -0.12 & -0.22 & -0.25 & -0.25 & -0.24 & -0.23 \\
\hline Government financial balance (\% GDP) & -0.04 & -0.19 & -0.30 & -0.35 & -0.36 & -0.31 \\
\hline Short-term interest rate (percentage points) & 0.31 & 0.87 & 0.94 & 0.88 & 0.72 & 0.50 \\
\hline Long-term interest rate (percentage points) & 0.26 & 0.77 & 0.89 & 0.87 & 0.74 & 0.54 \\
\hline Exchange rate (euro per US\$)* & 10.00 & 10.00 & 10.00 & 10.00 & 10.00 & 10.00 \\
\hline Share price index & -1.75 & -6.36 & -9.34 & -9.40 & -8.15 & -5.77 \\
\hline House price index & 0.07 & 0.18 & 0.31 & 0.62 & 1.16 & 1.89 \\
\hline M3 & 0.04 & -0.12 & -0.18 & -0.01 & 0.34 & 0.82 \\
\hline Bank loans & 0.03 & -0.18 & -0.97 & -2.13 & -3.28 & -4.21 \\
\hline Net wealth private sector & -0.17 & -0.44 & -0.42 & -0.18 & 0.25 & 0.78 \\
\hline Effective exchange rate ${ }^{* *}$ & -2.39 & -2.39 & -2.39 & -2.39 & -2.39 & -2.39 \\
\hline World trade volume & -0.05 & -0.21 & -0.28 & -0.31 & -0.33 & -0.38 \\
\hline Weighted export price & 1.82 & 1.77 & 1.89 & 2.11 & 2.39 & 2.67 \\
\hline Weighted import price & 1.74 & 1.71 & 1.83 & 2.05 & 2.33 & 2.61 \\
\hline
\end{tabular}

A: Absolute difference from base level

P: Percentage difference from base level

* (+) reflects a depreciation of the euro

** $(+)$ reflects an appreciation 


\section{Table 3.3b}

Permanent appreciation of the effective exchange rate of the US-dollar by $10 \%$ Cumulated effects in percentages, unless stated otherwise

\begin{tabular}{|c|c|c|c|c|c|c|c|}
\hline \multicolumn{8}{|l|}{ United States } \\
\hline Effects & $\underline{\text { Year } 1}$ & Year 2 & $\underline{\text { Year } 3}$ & $\underline{\text { Year } 4}$ & $\underline{\text { Year } 5}$ & $\underline{\text { Year } 6}$ & \\
\hline Real gross domestic product (GDP) & -0.15 & -0.47 & -0.56 & -0.40 & -0.12 & 0.17 & $\mathrm{P}$ \\
\hline Private consumption & 0.00 & 0.08 & 0.34 & 0.73 & 1.09 & 1.35 & $\mathrm{P}$ \\
\hline Business investment & -0.22 & -0.70 & -0.64 & 0.02 & 0.87 & 1.56 & $\mathrm{P}$ \\
\hline Housing investment & 0.01 & 0.15 & 0.42 & 0.65 & 0.73 & 0.70 & $\mathrm{P}$ \\
\hline Exports & -0.85 & -2.60 & -3.59 & -4.06 & -4.11 & -3.85 & $\mathrm{P}$ \\
\hline Imports & 0.00 & 0.42 & 1.42 & 2.51 & 3.25 & 3.56 & $\mathrm{P}$ \\
\hline Output gap & -0.17 & -0.53 & -0.62 & -0.46 & -0.18 & 0.08 & A \\
\hline Business employment & -0.09 & -0.34 & -0.51 & -0.48 & -0.31 & -0.08 & $\mathrm{P}$ \\
\hline Unemployment (\% of labour force) & 0.07 & 0.28 & 0.41 & 0.39 & 0.25 & 0.06 & A \\
\hline Labour productivity per person & -0.07 & -0.16 & -0.08 & 0.07 & 0.20 & 0.27 & $\mathrm{P}$ \\
\hline Compensation per employee & -0.02 & -0.21 & -0.62 & -1.20 & -1.86 & -2.49 & $\mathrm{P}$ \\
\hline Unit labour cost & 0.05 & -0.06 & -0.55 & -1.27 & -2.05 & -2.76 & $\mathrm{P}$ \\
\hline Private consumption deflator & -0.01 & -0.13 & -0.49 & -1.09 & -1.81 & -2.53 & $\mathrm{P}$ \\
\hline Export deflator & -0.85 & -2.28 & -3.14 & -3.89 & -4.57 & -5.14 & $\mathrm{P}$ \\
\hline Import deflator & -0.65 & -2.38 & -3.78 & -4.71 & -5.27 & -5.53 & $\mathrm{P}$ \\
\hline GDP deflator & 0.00 & -0.09 & -0.39 & -0.94 & -1.63 & -2.35 & $\mathrm{P}$ \\
\hline Inflation (private consumption deflator) & -0.01 & -0.12 & -0.37 & -0.60 & -0.73 & -0.73 & A \\
\hline Cash flow & -0.26 & -0.73 & -0.94 & -1.11 & -1.39 & -1.82 & $\mathrm{P}$ \\
\hline Personal disposable income & -0.04 & -0.25 & -0.60 & -1.10 & -1.67 & -2.19 & $\mathrm{P}$ \\
\hline Trade balance ( $\%$ GDP) & -0.08 & -0.19 & -0.31 & -0.44 & -0.53 & -0.57 & A \\
\hline Government debt (\% GDP) & 0.11 & 0.41 & 0.61 & 0.65 & 0.55 & 0.41 & A \\
\hline Government financial balance (\% GDP) & -0.02 & -0.05 & 0.04 & 0.22 & 0.38 & 0.45 & A \\
\hline Short-term interest rate (percentage points) & -0.14 & -0.55 & -0.93 & -1.10 & -1.05 & -0.85 & A \\
\hline Long-term interest rate (percentage points) & -0.11 & -0.48 & -0.84 & -1.04 & -1.03 & -0.88 & A \\
\hline Share price index & 0.48 & 3.38 & 8.38 & 10.72 & 11.60 & 10.40 & $\mathrm{P}$ \\
\hline House price index & 0.05 & 0.22 & 0.17 & -0.27 & -1.01 & -1.84 & $\mathrm{P}$ \\
\hline M3 & 0.02 & -0.06 & -0.34 & -0.93 & -1.83 & -2.88 & $\mathrm{P}$ \\
\hline Bank loans & -0.03 & -0.01 & 0.72 & 2.83 & 5.99 & 9.48 & $\mathrm{P}$ \\
\hline Net wealth private sector & -0.07 & -0.38 & -1.11 & -2.67 & -5.05 & -7.88 & $\mathrm{P}$ \\
\hline Effective exchange rate ${ }^{* *}$ & 10.00 & 10.00 & 10.00 & 10.00 & 10.00 & 10.00 & $\mathrm{P}$ \\
\hline World trade volume & -0.07 & -0.41 & -0.78 & -1.05 & -1.19 & -1.23 & $\mathrm{P}$ \\
\hline Weighted export price & -8.97 & -8.75 & -8.40 & -7.93 & -7.40 & -6.87 & $P$ \\
\hline Weighted import price & -8.96 & -8.72 & -8.38 & -7.93 & -7.43 & -6.92 & $\mathrm{P}$ \\
\hline
\end{tabular}

\footnotetext{
A: Absolute difference from base level
}

P: Percentage difference from base level

** (+) reflects an appreciation 
Table 3.4a

Permanent appreciation of the effective exchange rate of the euro by $10 \%$

Cumulated effects in percentages, unless stated otherwise

\section{Euro Area}

Effects

Private consumption

Business investment

Housing investment

Exports

Imports

Output gap

Business employment

Unemployment (\% of labour force)

Labour productivity per person

Compensation per employee

Unit labour cost

Private consumption deflator

Export deflator

Import deflator

GDP deflator

Inflation (private consumption deflator)

Cash flow

Personal disposable income

Trade balance (\% GDP)

Government debt (\% GDP)

Government financial balance (\% GDP)

Short-term interest rate (percentage points)

Long-term interest rate (percentage points)

Share price index

House price index

M3

Bank loans

Net wealth private sector

Effective exchange rate **

World trade volume

Weighted export price

Weighted import price
Real gross domestic product (GDP)

\begin{tabular}{|c|c|c|c|c|c|}
\hline Year 1 & Year 2 & Year 3 & Year 4 & Year 5 & Year 6 \\
\hline-0.35 & -0.41 & -0.17 & 0.15 & 0.48 & 0.75 \\
\hline 0.01 & 0.18 & 0.54 & 0.98 & 1.39 & 1.68 \\
\hline-0.32 & -0.15 & 0.49 & 1.26 & 1.95 & 2.35 \\
\hline 0.04 & 0.30 & 0.77 & 1.33 & 1.82 & 2.17 \\
\hline-0.83 & -1.45 & -1.51 & -1.38 & -1.09 & -0.69 \\
\hline-0.02 & -0.25 & -0.08 & 0.28 & 0.70 & 1.12 \\
\hline-0.43 & -0.49 & -0.24 & 0.08 & 0.39 & 0.61 \\
\hline-0.08 & -0.30 & -0.39 & -0.26 & 0.02 & 0.34 \\
\hline 0.06 & 0.23 & 0.29 & 0.20 & -0.01 & -0.26 \\
\hline-0.30 & -0.13 & 0.22 & 0.46 & 0.54 & 0.51 \\
\hline-0.16 & -0.91 & -1.86 & -2.87 & -3.80 & -4.54 \\
\hline 0.16 & -0.77 & -2.06 & -3.30 & -4.33 & -5.05 \\
\hline-0.15 & -0.84 & -1.86 & -2.98 & -4.05 & -4.93 \\
\hline-0.75 & -1.50 & -2.07 & -2.76 & -3.49 & -4.15 \\
\hline-1.67 & -3.14 & -3.72 & -4.15 & -4.53 & -4.88 \\
\hline-0.10 & -0.67 & -1.60 & -2.68 & -3.75 & -4.67 \\
\hline-0.15 & -0.70 & -1.03 & -1.15 & -1.11 & -0.92 \\
\hline-0.82 & -1.12 & -1.46 & -2.03 & -2.80 & -3.64 \\
\hline-0.22 & -0.74 & -1.20 & -1.70 & -2.30 & -2.86 \\
\hline 0.01 & -0.10 & -0.21 & -0.39 & -0.57 & -0.68 \\
\hline 0.27 & 0.45 & 0.45 & 0.36 & 0.22 & 0.12 \\
\hline 0.06 & 0.28 & 0.51 & 0.67 & 0.71 & 0.61 \\
\hline-0.54 & -1.42 & -1.72 & -1.67 & -1.38 & -0.93 \\
\hline-0.45 & -1.25 & -1.62 & -1.64 & -1.41 & -1.01 \\
\hline 3.45 & 14.27 & 27.71 & 29.96 & 25.36 & 16.48 \\
\hline-0.03 & 0.01 & 0.06 & -0.20 & -0.99 & -2.30 \\
\hline 0.13 & 0.52 & 0.94 & 0.88 & 0.26 & -0.78 \\
\hline-0.08 & 0.36 & 2.23 & 5.80 & 9.90 & 13.31 \\
\hline-0.02 & -0.32 & -1.05 & -2.21 & -3.69 & -5.27 \\
\hline 10.00 & 10.00 & 10.00 & 10.00 & 10.00 & 10.00 \\
\hline-0.01 & -0.13 & -0.09 & 0.03 & 0.27 & 0.58 \\
\hline-4.86 & -4.99 & -5.16 & -5.39 & -5.61 & -5.79 \\
\hline-4.58 & -4.74 & -4.92 & -5.16 & -5.40 & -5.61 \\
\hline
\end{tabular}

A: Absolute difference from base level

$\mathrm{P}$ : Percentage difference from base level

** (+) reflects an appreciation 


\section{Table 3.4b}

Permanent appreciation of the effective exchange rate of the euro by $10 \%$ Cumulated effects in percentages, unless stated otherwise

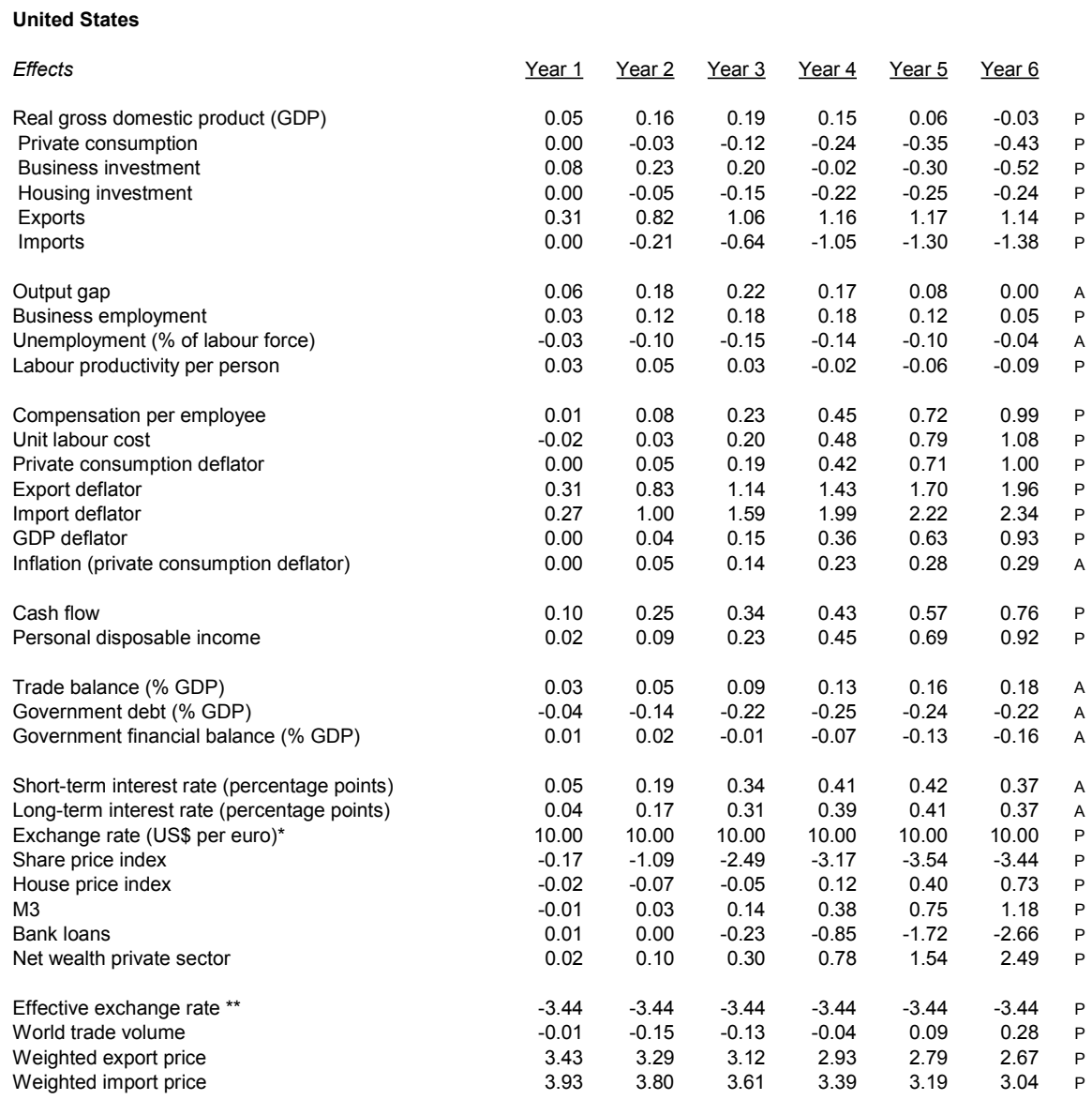

A: Absolute difference from base leve

P: Percentage difference from base level

* $(+)$ reflects a depreciation of the US\$

** $(+)$ reflects an appreciation 
Table 3.5a

Permanent increase in non-wage government consumption by $1 \%$ of GDP in all euro area countries Cumulated effects in percentages, unless stated otherwise

\begin{tabular}{|c|c|c|c|c|c|c|}
\hline Effects & $\underline{\text { Year } 1}$ & Year 2 & Year 3 & Year 4 & $\underline{\text { Year } 5}$ & $\underline{\text { Year } 6}$ \\
\hline Real gross domestic product (GDP) & 0.90 & 0.72 & 0.56 & 0.29 & -0.01 & -0.33 \\
\hline Private consumption & 0.01 & -0.12 & -0.32 & -0.66 & -1.11 & -1.59 \\
\hline Business investment & 1.00 & 1.07 & 0.33 & -0.47 & -1.13 & -1.63 \\
\hline Housing investment & -0.16 & -0.59 & -1.06 & -1.53 & -2.02 & -2.55 \\
\hline Exports & 0.00 & 0.45 & 0.76 & 0.83 & 0.71 & 0.45 \\
\hline Imports & 0.56 & 1.55 & 1.67 & 1.50 & 1.10 & 0.61 \\
\hline Output gap & 1.07 & 0.79 & 0.56 & 0.28 & -0.02 & -0.30 \\
\hline Business employment & 0.27 & 0.50 & 0.50 & 0.33 & 0.08 & -0.20 \\
\hline Unemployment (\% of labour force) & -0.20 & -0.38 & -0.38 & -0.25 & -0.06 & 0.15 \\
\hline Labour productivity per person & 0.71 & 0.25 & 0.04 & -0.09 & -0.18 & -0.25 \\
\hline Compensation per employee & 0.27 & 0.77 & 1.30 & 1.91 & 2.59 & 3.26 \\
\hline Unit labour cost & -0.44 & 0.51 & 1.25 & 2.01 & 2.79 & 3.54 \\
\hline Private consumption deflator & 0.05 & 0.34 & 0.81 & 1.48 & 2.26 & 3.08 \\
\hline Export deflator & -0.06 & -0.03 & 0.17 & 0.58 & 1.15 & 1.80 \\
\hline Import deflator & -0.14 & -0.28 & -0.30 & -0.25 & -0.06 & 0.26 \\
\hline GDP deflator & 0.03 & 0.28 & 0.68 & 1.30 & 2.04 & 2.83 \\
\hline Inflation (private consumption deflator) & 0.05 & 0.30 & 0.46 & 0.67 & 0.77 & 0.80 \\
\hline Cash flow & 1.72 & 1.04 & 0.91 & 1.07 & 1.44 & 1.95 \\
\hline Personal disposable income & 0.39 & 0.39 & 0.26 & 0.20 & 0.25 & 0.29 \\
\hline Trade balance (\% GDP) & -0.16 & -0.20 & -0.05 & 0.15 & 0.37 & 0.56 \\
\hline Government debt (\% GDP) & 0.36 & 1.33 & 2.12 & 2.82 & 3.47 & 4.00 \\
\hline Government financial balance (\% GDP) & -1.02 & -1.03 & -0.97 & -0.97 & -0.97 & -0.88 \\
\hline Short-term interest rate (percentage points) & 0.87 & 1.04 & 1.11 & 1.21 & 1.14 & 0.98 \\
\hline Long-term interest rate (percentage points) & 0.75 & 0.96 & 1.07 & 1.18 & 1.14 & 1.00 \\
\hline Exchange rate (euro per US\$)* & -0.85 & -0.94 & -0.90 & -0.82 & -0.51 & -0.04 \\
\hline Share price index & -5.08 & -7.85 & -11.06 & -12.70 & -12.82 & -11.61 \\
\hline House price index & -0.27 & -0.85 & -1.38 & -1.51 & -1.13 & -0.25 \\
\hline M3 & -0.58 & -0.94 & -0.98 & -0.82 & -0.44 & 0.12 \\
\hline Bank loans & 0.11 & -0.51 & -1.67 & -3.16 & -4.74 & -6.20 \\
\hline Net wealth private sector & 0.72 & 1.75 & 2.88 & 4.21 & 5.84 & 7.68 \\
\hline Effective exchange rate ** & 0.65 & 0.70 & 0.64 & 0.57 & 0.35 & 0.03 \\
\hline World trade volume & 0.36 & 1.02 & 1.14 & 1.03 & 0.75 & 0.39 \\
\hline Weighted export price & -0.41 & -0.43 & -0.29 & -0.04 & 0.40 & 0.96 \\
\hline Weighted import price & -0.38 & -0.40 & -0.26 & -0.01 & 0.43 & 0.98 \\
\hline
\end{tabular}

A: Absolute difference from base level

P: Percentage difference from base level

* (+) reflects a depreciation of the euro

** $(+)$ reflects an appreciation 


\section{Table 3.5b}

Permanent increase in non-wage government consumption by $1 \%$ of GDP in all euro area countries Cumulated effects in percentages, unless stated otherwise

\section{The Netherlands}

Effects

Real gross domestic product (GDP)

Business investment

Housing investment

Exports

Imports

Output gap

Business employment

Unemployment (\% of labour force)

Labour productivity per person

Compensation per employee

Unit labour cost

Private consumption deflator

Export deflator

Import deflator

GDP deflator

Inflation (private consumption deflator)

Cash flow

Personal disposable income

Trade balance (\% GDP)

Government debt (\% GDP)

Government financial balance (\% GDP)

Short-term interest rate (percentage points)

Long-term interest rate (percentage points)

Exchange rate (euro per US\$)*

Share price index

House price index

M3

Bank loans

Net wealth private sector

Effective exchange rate **

World trade volume

Weighted export price

Weighted import price
Private consumption

\begin{tabular}{|c|c|c|c|c|c|}
\hline Year 1 & Year 2 & Year 3 & Year 4 & $\underline{\text { Year } 5}$ & Year 6 \\
\hline 0.68 & 0.48 & 0.36 & 0.24 & 0.08 & -0.10 \\
\hline-0.02 & -0.22 & -0.60 & -1.05 & -1.51 & -1.91 \\
\hline 0.20 & 0.25 & -0.22 & -0.69 & -0.94 & -0.92 \\
\hline-0.61 & -2.21 & -3.63 & -4.49 & -4.72 & -4.36 \\
\hline 0.02 & 0.57 & 0.96 & 1.07 & 1.00 & 0.78 \\
\hline 0.34 & 1.20 & 1.36 & 1.14 & 0.86 & 0.58 \\
\hline 0.82 & 0.57 & 0.44 & 0.33 & 0.19 & 0.03 \\
\hline 0.20 & 0.47 & 0.57 & 0.52 & 0.34 & 0.09 \\
\hline-0.17 & -0.41 & -0.49 & -0.45 & -0.30 & -0.08 \\
\hline 0.54 & 0.03 & -0.22 & -0.31 & -0.33 & -0.29 \\
\hline 0.06 & 0.25 & 0.64 & 1.27 & 2.12 & 3.10 \\
\hline-0.48 & 0.22 & 0.85 & 1.59 & 2.46 & 3.40 \\
\hline 0.00 & 0.04 & 0.26 & 0.75 & 1.49 & 2.42 \\
\hline-0.15 & -0.21 & -0.13 & 0.07 & 0.43 & 0.93 \\
\hline-0.17 & -0.34 & -0.39 & -0.34 & -0.14 & 0.20 \\
\hline 0.00 & 0.03 & 0.19 & 0.62 & 1.30 & 2.19 \\
\hline 0.00 & 0.04 & 0.22 & 0.49 & 0.74 & 0.92 \\
\hline 1.41 & 0.53 & 0.17 & 0.21 & 0.58 & 1.26 \\
\hline-0.15 & -0.80 & -1.08 & -0.97 & -0.51 & 0.16 \\
\hline-0.18 & -0.19 & 0.08 & 0.38 & 0.61 & 0.76 \\
\hline 0.62 & 1.69 & 2.58 & 3.33 & 3.96 & 4.40 \\
\hline-0.99 & -1.00 & -0.93 & -0.93 & -0.94 & -0.87 \\
\hline 0.87 & 1.04 & 1.11 & 1.21 & 1.14 & 0.98 \\
\hline 0.75 & 0.96 & 1.07 & 1.18 & 1.14 & 1.00 \\
\hline-0.85 & -0.94 & -0.90 & -0.82 & -0.51 & -0.04 \\
\hline-6.98 & -9.77 & -12.67 & -13.73 & -13.57 & -12.34 \\
\hline-1.46 & -3.80 & -5.50 & -6.14 & -5.45 & -3.54 \\
\hline-0.49 & -1.13 & -1.43 & -1.31 & -0.74 & 0.20 \\
\hline-0.11 & -1.02 & -2.52 & -4.31 & -6.06 & -7.55 \\
\hline 0.50 & 1.23 & 2.11 & 3.26 & 4.66 & 6.21 \\
\hline 0.26 & 0.28 & 0.26 & 0.23 & 0.14 & 0.01 \\
\hline 0.45 & 1.14 & 1.15 & 0.99 & 0.68 & 0.31 \\
\hline-0.28 & -0.27 & -0.11 & 0.17 & 0.63 & 1.18 \\
\hline-0.34 & -0.34 & -0.21 & 0.04 & 0.46 & 0.98 \\
\hline
\end{tabular}

A: Absolute difference from base level

$P$ : Percentage difference from base level

* $(+)$ reflects a depreciation of the euro

** $(+)$ reflects an appreciation 
Table 3.5c

Permanent increase in non-wage government consumption by $1 \%$ of GDP in France, Germany and Italy Cumulated effects in percentages, unless stated otherwise

\begin{tabular}{|c|c|c|c|c|c|c|}
\hline Effects & $\underline{\text { Year } 1}$ & Year 2 & Year 3 & Year 4 & $\underline{\text { Year } 5}$ & $\underline{\text { Year } 6}$ \\
\hline Real gross domestic product (GDP) & 0.66 & 0.50 & 0.38 & 0.20 & -0.02 & -0.26 \\
\hline Private consumption & 0.00 & -0.16 & -0.33 & -0.56 & -0.88 & -1.23 \\
\hline Business investment & 0.81 & 0.71 & 0.11 & -0.43 & -0.88 & -1.26 \\
\hline Housing investment & -0.12 & -0.44 & -0.84 & -1.27 & -1.71 & -2.14 \\
\hline Exports & 0.00 & 0.33 & 0.52 & 0.54 & 0.45 & 0.27 \\
\hline Imports & 0.42 & 1.09 & 1.06 & 0.91 & 0.63 & 0.30 \\
\hline Output gap & 0.79 & 0.56 & 0.41 & 0.21 & 0.00 & -0.22 \\
\hline Business employment & 0.20 & 0.31 & 0.31 & 0.22 & 0.09 & -0.05 \\
\hline Unemployment (\% of labour force) & -0.15 & -0.23 & -0.23 & -0.17 & -0.07 & 0.04 \\
\hline Labour productivity per person & 0.52 & 0.22 & 0.07 & -0.06 & -0.18 & -0.29 \\
\hline Compensation per employee & 0.18 & 0.45 & 0.78 & 1.21 & 1.69 & 2.18 \\
\hline Unit labour cost & -0.33 & 0.27 & 0.76 & 1.34 & 1.96 & 2.58 \\
\hline Private consumption deflator & 0.03 & 0.20 & 0.48 & 0.94 & 1.53 & 2.20 \\
\hline Export deflator & -0.04 & -0.01 & 0.12 & 0.39 & 0.80 & 1.26 \\
\hline Import deflator & -0.10 & -0.19 & -0.20 & -0.17 & -0.07 & 0.13 \\
\hline GDP deflator & 0.00 & 0.14 & 0.39 & 0.80 & 1.35 & 1.98 \\
\hline Inflation (private consumption deflator) & 0.03 & 0.17 & 0.28 & 0.46 & 0.58 & 0.65 \\
\hline Cash flow & 1.24 & 0.76 & 0.62 & 0.65 & 0.88 & 1.25 \\
\hline Personal disposable income & 0.26 & 0.15 & 0.01 & -0.03 & 0.02 & 0.09 \\
\hline Trade balance ( $\%$ GDP) & -0.12 & -0.14 & -0.01 & 0.13 & 0.29 & 0.43 \\
\hline Government debt ( $\%$ GDP) & 0.28 & 1.03 & 1.63 & 2.14 & 2.59 & 2.95 \\
\hline Government financial balance (\% GDP) & -0.75 & -0.75 & -0.69 & -0.69 & -0.69 & -0.64 \\
\hline Short-term interest rate (percentage points) & 0.63 & 0.68 & 0.73 & 0.84 & 0.87 & 0.82 \\
\hline Long-term interest rate (percentage points) & 0.54 & 0.63 & 0.70 & 0.81 & 0.86 & 0.82 \\
\hline Exchange rate (euro per US\$)* & -0.62 & -0.61 & -0.60 & -0.60 & -0.47 & -0.19 \\
\hline Share price index & -3.77 & -5.31 & -7.56 & -9.10 & -9.88 & -9.60 \\
\hline House price index & -0.23 & -0.73 & -1.14 & -1.23 & -0.94 & -0.25 \\
\hline M3 & -0.48 & -0.72 & -0.80 & -0.79 & -0.66 & -0.39 \\
\hline Bank loans & -0.02 & -0.49 & -1.35 & -2.42 & -3.60 & -4.77 \\
\hline Net wealth private sector & 0.52 & 1.27 & 2.11 & 3.08 & 4.25 & 5.60 \\
\hline Effective exchange rate ** & 0.47 & 0.45 & 0.42 & 0.42 & 0.33 & 0.14 \\
\hline World trade volume & 0.26 & 0.68 & 0.68 & 0.58 & 0.39 & 0.16 \\
\hline Weighted export price & -0.30 & -0.27 & -0.18 & -0.02 & 0.27 & 0.67 \\
\hline Weighted import price & -0.28 & -0.25 & -0.16 & 0.00 & 0.28 & 0.67 \\
\hline
\end{tabular}

A: Absolute difference from base level

P: Percentage difference from base level

* $(+)$ reflects a depreciation of the euro

** $(+)$ reflects an appreciation 


\section{Table 3.5d}

Permanent increase in non-wage government consumption by $1 \%$ of GDP in France, Germany and Italy Cumulated effects in percentages, unless stated otherwise

\section{The Netherlands}

Effects

Real gross domestic product (GDP)

Private consumption

Business investment

Housing investment

Exports

Imports

Output gap

Business employment

Unemployment (\% of labour force)

Labour productivity per person

Compensation per employee

Unit labour cost

Private consumption deflator

Export deflator

Import deflator

GDP deflator

Inflation (private consumption deflator)

Cash flow

Personal disposable income

Trade balance (\% GDP)

Government debt (\% GDP)

Government financial balance (\% GDP)

Short-term interest rate (percentage points)

Long-term interest rate (percentage points)

Exchange rate (euro per US\$)*

Share price index

House price index

M3

Bank loans

Net wealth private sector

Effective exchange rate **

World trade volume

Weighted export price

Weighted import price

\begin{tabular}{|c|c|c|c|c|c|}
\hline Year 1 & Year 2 & Year 3 & Year 4 & Year 5 & Year 6 \\
\hline-0.07 & 0.04 & 0.00 & -0.15 & -0.25 & -0.35 \\
\hline-0.09 & -0.30 & -0.49 & -0.73 & -0.98 & -1.21 \\
\hline-0.24 & -0.72 & -0.83 & -1.15 & -1.52 & -1.73 \\
\hline-0.47 & -1.68 & -2.81 & -3.77 & -4.48 & -4.86 \\
\hline 0.01 & 0.47 & 0.76 & 0.81 & 0.74 & 0.61 \\
\hline-0.02 & -0.06 & 0.11 & 0.09 & -0.15 & -0.41 \\
\hline-0.08 & 0.10 & 0.10 & -0.04 & -0.11 & -0.17 \\
\hline-0.02 & -0.02 & 0.03 & 0.01 & -0.07 & -0.18 \\
\hline 0.01 & 0.02 & -0.03 & -0.01 & 0.06 & 0.15 \\
\hline-0.06 & 0.07 & -0.03 & -0.18 & -0.21 & -0.21 \\
\hline-0.01 & -0.07 & -0.14 & -0.16 & -0.11 & -0.02 \\
\hline 0.05 & -0.14 & -0.11 & 0.02 & 0.10 & 0.19 \\
\hline-0.01 & -0.07 & -0.15 & -0.18 & -0.12 & 0.01 \\
\hline-0.11 & -0.14 & -0.07 & 0.04 & 0.24 & 0.50 \\
\hline-0.13 & -0.23 & -0.26 & -0.23 & -0.13 & 0.07 \\
\hline 0.00 & -0.05 & -0.13 & -0.18 & -0.14 & -0.03 \\
\hline-0.01 & -0.06 & -0.09 & -0.03 & 0.06 & 0.13 \\
\hline-0.14 & 0.17 & -0.02 & -0.38 & -0.47 & -0.42 \\
\hline-0.26 & -0.68 & -0.91 & -1.13 & -1.23 & -1.24 \\
\hline 0.03 & 0.39 & 0.57 & 0.69 & 0.87 & 1.01 \\
\hline 0.21 & 0.42 & 0.77 & 1.25 & 1.75 & 2.21 \\
\hline-0.17 & -0.25 & -0.29 & -0.37 & -0.45 & -0.46 \\
\hline 0.63 & 0.68 & 0.73 & 0.84 & 0.87 & 0.82 \\
\hline 0.54 & 0.63 & 0.70 & 0.81 & 0.86 & 0.82 \\
\hline-0.62 & -0.61 & -0.60 & -0.60 & -0.47 & -0.19 \\
\hline-5.48 & -6.84 & -8.72 & -9.77 & -10.32 & -9.96 \\
\hline-1.14 & -2.85 & -4.20 & -5.26 & -5.86 & -5.84 \\
\hline-0.42 & -0.84 & -1.25 & -1.51 & -1.54 & -1.34 \\
\hline-0.13 & -0.84 & -1.84 & -3.10 & -4.45 & -5.76 \\
\hline 0.09 & 0.55 & 1.30 & 2.25 & 3.43 & 4.81 \\
\hline 0.19 & 0.18 & 0.17 & 0.17 & 0.13 & 0.06 \\
\hline 0.36 & 0.92 & 0.86 & 0.72 & 0.48 & 0.21 \\
\hline-0.20 & -0.17 & -0.06 & 0.13 & 0.45 & 0.86 \\
\hline-0.24 & -0.22 & -0.14 & 0.00 & 0.25 & 0.60 \\
\hline
\end{tabular}

A: Absolute difference from base leve

$P:$ Percentage difference from base leve

* $(+)$ reflects a depreciation of the euro

** $(+)$ reflects an appreciation 
Table 3.5e

Permanent increase in non-wage government consumption by $1 \%$ of GDP in the United States Cumulated effects in percentages, unless stated otherwise

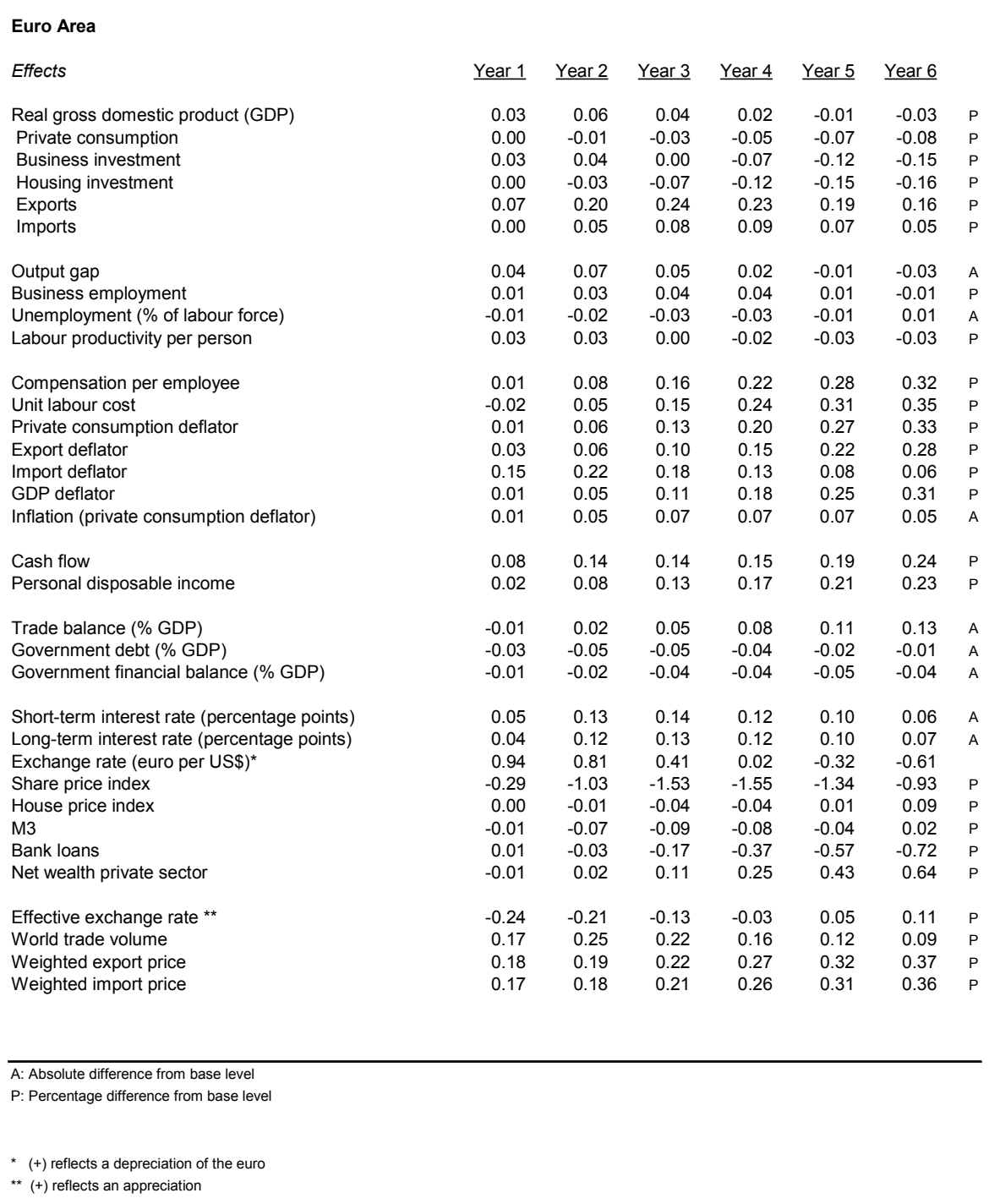




\section{Table $3.5 f$}

Permanent increase in non-wage government consumption by $1 \%$ of GDP in the United States Cumulated effects in percentages, unless stated otherwise

\section{United States}

Effects

Real gross domestic product (GDP)

Business investment

Housing investment

Exports

Imports

Output gap

Business employment

Unemployment (\% of labour force)

Labour productivity per person

Compensation per employee

Unit labour cost

Private consumption deflator

Export deflator

Import deflator

GDP deflator

Inflation (private consumption deflator)

Cash flow

Personal disposable income

Trade balance (\% GDP)

Government debt (\% GDP)

Government financial balance (\% GDP)

Short-term interest rate (percentage points)

Exchange rate (US\$ per euro)*

Share price index

House price index

M3

Bank loans

Net wealth private sector

Effective exchange rate **

World trade volume

Weighted export price
Private consumption

Long-term interest rate (percentage points)

Weighted import price

\begin{tabular}{|c|c|c|c|c|c|}
\hline Year 1 & Year 2 & Year 3 & Year 4 & Year 5 & Year 6 \\
\hline 1.08 & 0.78 & 0.33 & -0.06 & -0.33 & -0.49 \\
\hline-0.05 & -0.25 & -0.61 & -0.95 & -1.22 & -1.44 \\
\hline 1.96 & 1.58 & 0.25 & -0.86 & -1.45 & -1.61 \\
\hline-0.20 & -0.72 & -1.01 & -1.14 & -1.23 & -1.39 \\
\hline-0.09 & -0.25 & -0.32 & -0.35 & -0.36 & -0.36 \\
\hline 1.30 & 1.75 & 1.30 & 0.84 & 0.54 & 0.38 \\
\hline 1.22 & 0.79 & 0.27 & -0.13 & -0.36 & -0.46 \\
\hline 0.68 & 0.70 & 0.42 & 0.09 & -0.16 & -0.33 \\
\hline-0.56 & -0.57 & -0.34 & -0.08 & 0.13 & 0.27 \\
\hline 0.46 & 0.11 & -0.09 & -0.18 & -0.21 & -0.21 \\
\hline 0.28 & 0.69 & 1.01 & 1.23 & 1.40 & 1.52 \\
\hline-0.19 & 0.58 & 1.09 & 1.41 & 1.62 & 1.73 \\
\hline 0.06 & 0.36 & 0.71 & 1.07 & 1.36 & 1.56 \\
\hline-0.08 & -0.04 & 0.29 & 0.71 & 1.10 & 1.39 \\
\hline-0.07 & -0.23 & -0.32 & -0.28 & -0.15 & 0.04 \\
\hline 0.04 & 0.28 & 0.63 & 0.98 & 1.29 & 1.51 \\
\hline 0.06 & 0.30 & 0.36 & 0.35 & 0.29 & 0.20 \\
\hline 1.71 & 0.91 & 0.53 & 0.49 & 0.65 & 0.85 \\
\hline 0.36 & 0.33 & 0.11 & -0.10 & -0.32 & -0.58 \\
\hline-0.19 & -0.25 & -0.16 & -0.07 & -0.01 & 0.02 \\
\hline 0.11 & 0.91 & 1.76 & 2.51 & 3.12 & 3.50 \\
\hline-0.76 & -0.80 & -0.80 & -0.75 & -0.64 & -0.44 \\
\hline 0.99 & 0.97 & 0.65 & 0.34 & 0.09 & -0.10 \\
\hline 0.84 & 0.91 & 0.67 & 0.39 & 0.15 & -0.05 \\
\hline-0.93 & -0.80 & -0.41 & -0.02 & 0.32 & 0.61 \\
\hline-4.00 & -6.47 & -6.62 & -4.56 & -2.75 & -0.92 \\
\hline-0.52 & -0.44 & -0.02 & 0.31 & 0.42 & 0.31 \\
\hline-0.08 & 0.08 & 0.46 & 1.02 & 1.62 & 2.11 \\
\hline 0.27 & -0.35 & -2.12 & -4.18 & -5.65 & -6.28 \\
\hline 1.09 & 2.71 & 4.54 & 6.58 & 8.57 & 10.18 \\
\hline 0.94 & 0.80 & 0.38 & -0.01 & -0.33 & -0.60 \\
\hline-0.01 & 0.00 & 0.02 & 0.03 & 0.04 & 0.06 \\
\hline-0.92 & -0.76 & -0.29 & 0.16 & 0.56 & 0.89 \\
\hline-0.92 & -0.76 & -0.30 & 0.16 & 0.56 & 0.89 \\
\hline
\end{tabular}

A: Absolute difference from base level

$P$ : Percentage difference from base level

* $(+)$ reflects a depreciation of the US\$

** $(+)$ reflects an appreciation 
Table 3.6

Permanent ex ante balanced-budget reduction in income taxes by $1 \%$ of GDP in the euro area (accompanied by a reduction in non-wage government consumption)

Cumulated effects in percentages, unless stated otherwise

Euro Area

Effects

Real gross domestic product (GDP)

Private consumption

Business investment

Housing investment

Exports

Imports

Output gap

Business employment

Unemployment (\% of labour force)

Labour productivity per person

Compensation per employee

Unit labour cost

Private consumption deflator

Export deflator

Import deflator

GDP deflator

Inflation (private consumption deflator)

Cash flow

Personal disposable income

Trade balance (\% GDP)

Government debt (\% GDP)

Government financial balance (\% GDP)

Short-term interest rate (percentage points)

Long-term interest rate (percentage points)

Exchange rate (euro per US\$)*

Share price index

House price index

M3

Bank loans

Net wealth private sector

$\underline{\text { Year } 1} \underline{\text { Year } 2} \underline{\text { Year } 3}$ Year 4 Year 5 Year 6

Effective exchange rate **

World trade volume

Weighted export price

Weighted import price

\begin{tabular}{|c|c|c|c|c|c|}
\hline ar 1 & Year 2 & Year 3 & Year 4 & Year 5 & Year 6 \\
\hline-0.57 & -0.17 & 0.09 & 0.33 & 0.51 & 0.64 \\
\hline 0.38 & 0.93 & 1.38 & 1.78 & 2.10 & 2.31 \\
\hline 0.34 & 0.64 & 1.09 & 1.37 & 1.47 & 1.44 \\
\hline 0.29 & 1.12 & 1.99 & 2.67 & 3.13 & 3.39 \\
\hline 0.00 & -0.29 & -0.35 & -0.22 & 0.00 & 0.22 \\
\hline-0.38 & -0.86 & -0.57 & -0.18 & 0.21 & 0.49 \\
\hline-0.75 & -0.32 & -0.09 & 0.11 & 0.25 & 0.33 \\
\hline-0.19 & -0.28 & -0.20 & -0.05 & 0.11 & 0.23 \\
\hline 0.14 & 0.21 & 0.15 & 0.03 & -0.08 & -0.17 \\
\hline-0.44 & 0.11 & 0.32 & 0.42 & 0.46 & 0.47 \\
\hline-0.17 & -0.43 & -0.62 & -0.82 & -1.03 & -1.17 \\
\hline 0.26 & -0.55 & -0.94 & -1.26 & -1.51 & -1.68 \\
\hline-0.05 & -0.30 & -0.64 & -1.04 & -1.42 & -1.74 \\
\hline 0.04 & 0.00 & -0.19 & -0.50 & -0.86 & -1.18 \\
\hline 0.10 & 0.18 & 0.16 & 0.07 & -0.10 & -0.32 \\
\hline-0.03 & -0.23 & -0.53 & -0.91 & -1.29 & -1.62 \\
\hline-0.05 & -0.25 & -0.35 & -0.40 & -0.39 & -0.32 \\
\hline-1.21 & -0.39 & -0.36 & -0.57 & -0.89 & -1.26 \\
\hline 2.13 & 2.09 & 1.96 & 1.81 & 1.58 & 1.36 \\
\hline 0.11 & 0.08 & -0.08 & -0.23 & -0.35 & -0.41 \\
\hline 0.30 & -0.10 & -0.47 & -0.90 & -1.39 & -1.89 \\
\hline 0.14 & 0.25 & 0.41 & 0.54 & 0.63 & 0.64 \\
\hline-0.64 & -0.62 & -0.59 & -0.52 & -0.39 & -0.24 \\
\hline-0.55 & -0.58 & -0.58 & -0.53 & -0.41 & -0.27 \\
\hline 0.63 & 0.54 & 0.44 & 0.26 & -0.02 & -0.34 \\
\hline 4.54 & 6.16 & 8.36 & 7.95 & 6.13 & 3.60 \\
\hline 0.58 & 1.49 & 1.93 & 1.89 & 1.40 & 0.56 \\
\hline 0.46 & 0.69 & 0.71 & 0.56 & 0.27 & -0.09 \\
\hline 0.16 & 0.90 & 1.85 & 2.95 & 3.97 & 4.69 \\
\hline-0.03 & -0.13 & -0.60 & -1.45 & -2.60 & -3.90 \\
\hline-0.47 & -0.40 & -0.30 & -0.17 & 0.02 & 0.24 \\
\hline-0.25 & -0.58 & -0.41 & -0.15 & 0.13 & 0.34 \\
\hline 0.30 & 0.23 & 0.08 & -0.16 & -0.47 & -0.78 \\
\hline 0.28 & 0.22 & 0.07 & -0.17 & -0.47 & -0.78 \\
\hline
\end{tabular}

\footnotetext{
A: Absolute difference from base leve

$P$ : Percentage difference from base leve

* $(+)$ reflects a depreciation of the euro

** $(+)$ reflects an appreciation
} 
Table 3.7

Permanent increase in indirect taxes in the euro area by $1 \%$ of GDP Cumulated effects in percentages, unless stated otherwise

\section{Euro Area}

Effects

Real gross domestic product (GDP)

Private consumption

Business investment

Housing investment

Exports

Imports

Output gap

Business employment

Unemployment (\% of labour force)

Labour productivity per person

Compensation per employee

Unit labour cost

Private consumption deflator

Export deflator

Import deflator

GDP deflator

Inflation (private consumption deflator)

Cash flow

Personal disposable income

Trade balance (\% GDP)

Government debt (\% GDP)

Government financial balance (\% GDP)

Short-term interest rate (percentage points)

Long-term interest rate (percentage points)

Exchange rate (euro per US\$)*

Share price index

M3

Bank loans

Net wealth private sector

Effective exchange rate **

World trade volume

Weighted export price

Weighted import price
House price index

\begin{tabular}{|c|c|c|c|c|c|}
\hline Year 1 & Year 2 & Year 3 & Year 4 & Year 5 & Year 6 \\
\hline-0.08 & -0.26 & -0.42 & -0.55 & -0.61 & -0.61 \\
\hline-0.17 & -0.34 & -0.56 & -0.74 & -0.82 & -0.79 \\
\hline 0.07 & -0.26 & -0.59 & -0.80 & -0.87 & -0.79 \\
\hline 0.26 & 0.66 & 0.43 & -0.01 & -0.41 & -0.64 \\
\hline 0.01 & 0.07 & 0.01 & -0.11 & -0.26 & -0.39 \\
\hline 0.09 & 0.22 & 0.12 & -0.11 & -0.32 & -0.41 \\
\hline 0.04 & -0.16 & -0.31 & -0.42 & -0.45 & -0.42 \\
\hline 0.00 & -0.08 & -0.23 & -0.38 & -0.49 & -0.54 \\
\hline 0.00 & 0.06 & 0.17 & 0.29 & 0.37 & 0.41 \\
\hline 0.02 & -0.09 & -0.13 & -0.11 & -0.06 & -0.01 \\
\hline 0.12 & 0.57 & 1.01 & 1.43 & 1.79 & 2.04 \\
\hline 0.11 & 0.65 & 1.13 & 1.54 & 1.86 & 2.07 \\
\hline 1.40 & 1.68 & 2.17 & 2.68 & 3.10 & 3.41 \\
\hline 0.33 & 0.75 & 1.10 & 1.52 & 1.91 & 2.24 \\
\hline 0.04 & 0.14 & 0.27 & 0.50 & 0.81 & 1.15 \\
\hline 1.07 & 1.56 & 2.02 & 2.52 & 2.96 & 3.29 \\
\hline 1.39 & 0.27 & 0.48 & 0.49 & 0.42 & 0.30 \\
\hline 0.42 & 0.70 & 0.95 & 1.39 & 1.88 & 2.34 \\
\hline 0.27 & 0.73 & 1.24 & 1.70 & 2.13 & 2.47 \\
\hline 0.07 & 0.18 & 0.28 & 0.38 & 0.44 & 0.44 \\
\hline-1.24 & -1.85 & -2.25 & -2.57 & -2.84 & -3.10 \\
\hline 0.53 & 0.40 & 0.19 & 0.06 & 0.02 & 0.03 \\
\hline 0.00 & 0.29 & 0.49 & 0.43 & 0.29 & 0.12 \\
\hline 0.00 & 0.24 & 0.44 & 0.42 & 0.30 & 0.16 \\
\hline 0.13 & 0.07 & 0.13 & 0.48 & 0.93 & 1.39 \\
\hline 0.18 & -0.93 & -3.39 & -3.16 & -1.48 & 0.93 \\
\hline 1.51 & 2.66 & 3.23 & 3.17 & 2.98 & 2.93 \\
\hline 1.06 & 1.12 & 1.18 & 1.40 & 1.81 & 2.29 \\
\hline 0.14 & 0.30 & 0.09 & -0.42 & -0.98 & -1.37 \\
\hline-0.39 & -0.80 & -0.84 & -0.52 & -0.02 & 0.52 \\
\hline-0.10 & -0.06 & -0.12 & -0.39 & -0.71 & -1.03 \\
\hline 0.07 & 0.16 & 0.09 & -0.08 & -0.25 & -0.35 \\
\hline 0.22 & 0.42 & 0.63 & 1.02 & 1.44 & 1.83 \\
\hline 0.21 & 0.43 & 0.65 & 1.04 & 1.46 & 1.85 \\
\hline
\end{tabular}

A: Absolute difference from base level

$P$ : Percentage difference from base level

* $(+)$ reflects a depreciation of the euro

** $(+)$ reflects an appreciation 
Table 3.8a

Increase in oil prices by $\mathbf{2 5 \%}$ over $\mathbf{8}$ quarters

Cumulated effects in percentages, unless stated otherwise

\begin{tabular}{|c|c|c|c|c|c|c|c|}
\hline Effects & $\underline{\text { Year } 1}$ & Year 2 & $\underline{\text { Year } 3}$ & $\underline{\text { Year } 4}$ & $\underline{\text { Year } 5}$ & Year 6 & \\
\hline Real gross domestic product (GDP) & -0.03 & -0.14 & -0.22 & -0.21 & -0.20 & -0.20 & $\mathrm{P}$ \\
\hline Private consumption & -0.05 & -0.19 & -0.33 & -0.36 & -0.33 & -0.30 & $\mathrm{P}$ \\
\hline Business investment & -0.07 & -0.28 & -0.43 & -0.34 & -0.25 & -0.19 & $\mathrm{P}$ \\
\hline Housing investment & 0.00 & -0.04 & -0.19 & -0.43 & -0.59 & -0.60 & $\mathrm{P}$ \\
\hline Exports & 0.01 & -0.02 & -0.13 & -0.23 & -0.26 & -0.28 & $P$ \\
\hline Imports & 0.00 & -0.07 & -0.27 & -0.43 & -0.44 & -0.42 & $\mathrm{P}$ \\
\hline Output gap & -0.01 & -0.12 & -0.19 & -0.17 & -0.16 & -0.15 & A \\
\hline Business employment & 0.02 & 0.05 & 0.01 & -0.04 & -0.08 & -0.11 & $P$ \\
\hline Unemployment ( $\%$ of labour force) & -0.02 & -0.04 & -0.01 & 0.03 & 0.06 & 0.08 & A \\
\hline Labour productivity per person & -0.04 & -0.18 & -0.23 & -0.18 & -0.13 & -0.10 & $\mathrm{P}$ \\
\hline Compensation per employee & 0.00 & 0.23 & 0.50 & 0.57 & 0.59 & 0.59 & $\mathrm{P}$ \\
\hline Unit labour cost & 0.04 & 0.42 & 0.75 & 0.75 & 0.73 & 0.69 & $P$ \\
\hline Private consumption deflator & 0.18 & 0.52 & 0.77 & 0.82 & 0.86 & 0.86 & $\mathrm{P}$ \\
\hline Export deflator & 0.03 & 0.15 & 0.39 & 0.61 & 0.72 & 0.71 & $P$ \\
\hline Import deflator & 0.95 & 1.58 & 0.71 & 0.27 & 0.35 & 0.44 & $P$ \\
\hline GDP deflator & 0.12 & 0.43 & 0.71 & 0.80 & 0.83 & 0.83 & $P$ \\
\hline Inflation (private consumption deflator) & 0.18 & 0.34 & 0.24 & 0.05 & 0.03 & 0.00 & A \\
\hline Cash flow & 0.19 & 0.31 & 0.47 & 0.64 & 0.72 & 0.77 & $\mathrm{P}$ \\
\hline Personal disposable income & 0.01 & 0.11 & 0.26 & 0.33 & 0.38 & 0.38 & $\mathrm{P}$ \\
\hline Trade balance ( $\%$ GDP) & -0.31 & -0.38 & -0.03 & 0.18 & 0.18 & 0.15 & A \\
\hline Government debt (\% GDP) & -0.02 & -0.03 & -0.03 & -0.04 & -0.05 & -0.09 & A \\
\hline Government financial balance ( $\%$ GDP) & -0.06 & -0.13 & -0.14 & -0.06 & -0.02 & 0.02 & A \\
\hline Short-term interest rate (percentage points) & 0.26 & 0.43 & 0.22 & -0.05 & -0.07 & -0.12 & A \\
\hline Long-term interest rate (percentage points) & 0.22 & 0.39 & 0.24 & 0.00 & -0.05 & -0.10 & A \\
\hline Exchange rate (euro per US\$)* & 0.17 & -0.34 & -0.66 & -0.24 & 0.00 & 0.26 & $\mathrm{P}$ \\
\hline Share price index & -1.56 & -3.43 & -3.09 & -0.10 & 1.17 & 2.03 & $P$ \\
\hline House price index & 0.10 & 0.22 & 0.31 & 0.43 & 0.62 & 0.83 & $\mathrm{P}$ \\
\hline M3 & 0.09 & 0.08 & 0.02 & 0.22 & 0.41 & 0.56 & $\mathrm{P}$ \\
\hline Bank loans & 0.00 & -0.21 & -0.65 & -0.98 & -0.98 & -0.80 & $\mathrm{P}$ \\
\hline Net wealth private sector & -0.16 & -0.53 & -0.61 & -0.32 & -0.04 & 0.16 & $\mathrm{P}$ \\
\hline Effective exchange rate ${ }^{* *}$ & -0.12 & 0.20 & 0.35 & 0.04 & -0.11 & -0.25 & $\mathrm{P}$ \\
\hline World trade volume & -0.02 & -0.12 & -0.27 & -0.29 & -0.27 & -0.26 & $P$ \\
\hline Weighted export price & 0.12 & 0.21 & 0.42 & 0.65 & 0.68 & 0.69 & $\mathrm{P}$ \\
\hline Weighted import price & 0.11 & 0.19 & 0.39 & 0.63 & 0.67 & 0.67 & $P$ \\
\hline
\end{tabular}

A: Absolute difference from base level

P: Percentage difference from base level

* (+) reflects a depreciation of the euro

** $(+)$ reflects an appreciation 


\section{Table 3.8b}

Increase in oil prices by $25 \%$ over 8 quarters

Cumulated effects in percentages, unless stated otherwise

\section{United States}

Effects

Real gross domestic product (GDP)

Private consumption

Business investment

Housing investment

Exports

Imports

Output gap

Business employment

Unemployment (\% of labour force)

Labour productivity per person

Compensation per employee

Unit labour cost

Private consumption deflator

Export deflator

Import deflator

GDP deflator

Inflation (private consumption deflator)

Cash flow

Personal disposable income

Trade balance (\% GDP)

Government debt (\% GDP)

Government financial balance (\% GDP)

Short-term interest rate (percentage points)

Long-term interest rate (percentage points)

Exchange rate (US\$ per euro)*

Share price index

House price index

M3

Bank loans

Net wealth private sector

Effective exchange rate **

World trade volume

Weighted export price

Weighted import price

$\begin{array}{rrrrrrr}\text { Year 1 } & \text { Year 2 } & \text { Year 3 } & \text { Year 4 } & \text { Year 5 } & \text { Year 6 } & \\ -0.14 & -0.33 & -0.25 & -0.04 & 0.04 & 0.07 & \mathrm{P} \\ -0.16 & -0.40 & -0.32 & -0.07 & -0.01 & 0.02 & \mathrm{P} \\ -0.21 & -0.63 & -0.50 & 0.10 & 0.37 & 0.44 & \mathrm{P} \\ -0.04 & -0.19 & -0.25 & -0.24 & -0.23 & -0.20 & \mathrm{P} \\ -0.02 & -0.07 & -0.09 & -0.06 & 0.01 & 0.07 & \mathrm{P} \\ -0.08 & -0.45 & -0.48 & -0.06 & 0.14 & 0.21 & \mathrm{P} \\ & & & & & & \\ -0.12 & -0.30 & -0.19 & 0.04 & 0.11 & 0.12 & \mathrm{~A} \\ 0.16 & 0.07 & -0.04 & 0.08 & 0.14 & 0.18 & \mathrm{P} \\ -0.13 & -0.06 & 0.04 & -0.06 & -0.12 & -0.14 & \mathrm{~A} \\ -0.28 & -0.40 & -0.20 & -0.09 & -0.08 & -0.08 & \mathrm{P} \\ & & & & & & \\ 0.00 & 0.19 & 0.20 & -0.03 & -0.21 & -0.35 & \mathrm{P} \\ 0.28 & 0.59 & 0.40 & 0.06 & -0.13 & -0.27 & \mathrm{P} \\ 0.43 & 0.73 & 0.52 & 0.23 & -0.02 & -0.20 & \mathrm{P} \\ 0.14 & 0.62 & 0.88 & 0.64 & 0.32 & 0.07 & \mathrm{P} \\ 1.29 & 2.25 & 1.15 & 0.44 & 0.48 & 0.52 & \mathrm{P} \\ 0.31 & 0.66 & 0.59 & 0.30 & 0.04 & -0.15 & \mathrm{P} \\ 0.43 & 0.29 & -0.21 & -0.29 & -0.24 & -0.18 & \mathrm{~A} \\ & & & & & & \\ 0.21 & 0.42 & 0.60 & 0.61 & 0.35 & 0.11 & \mathrm{P} \\ 0.06 & 0.18 & 0.14 & -0.03 & -0.20 & -0.29 & \mathrm{P} \\ & & & & & & \\ -0.15 & -0.20 & -0.03 & -0.01 & -0.06 & -0.09 & \mathrm{~A} \\ -0.03 & 0.03 & 0.05 & -0.06 & -0.13 & -0.19 & \mathrm{~A} \\ -0.07 & -0.15 & -0.03 & 0.14 & 0.17 & 0.16 & \mathrm{~A} \\ & & & & & & \\ 0.45 & 0.14 & -0.40 & -0.33 & -0.22 & -0.13 & \mathrm{~A} \\ 0.38 & 0.17 & -0.31 & -0.31 & -0.23 & -0.15 & \mathrm{~A} \\ -0.17 & 0.34 & 0.67 & 0.25 & 0.00 & -0.26 & \mathrm{P} \\ -2.00 & -1.48 & 2.41 & 3.36 & 2.74 & 2.09 & \mathrm{P} \\ 0.14 & 0.38 & 0.46 & 0.16 & -0.24 & -0.48 & \mathrm{P} \\ 0.46 & 0.90 & 0.90 & 0.67 & 0.19 & -0.26 & \mathrm{P} \\ 0.00 & -0.36 & -0.77 & -0.40 & 0.48 & 1.32 & \mathrm{P} \\ -0.17 & -0.35 & -0.41 & -0.71 & -1.35 & -2.09 & \mathrm{P} \\ 0.07 & -0.37 & -0.61 & -0.19 & 0.02 & 0.19 & \mathrm{P} \\ -0.01 & -0.07 & -0.21 & -0.26 & -0.25 & -0.25 & \mathrm{P} \\ -0.05 & 0.61 & 1.27 & 1.12 & 0.88 & 0.63 & \mathrm{P} \\ -0.06 & 0.57 & 1.21 & 1.06 & 0.84 & 0.59 & \mathrm{P} \\ & & & & & & \end{array}$

A: Absolute difference from base level

$P$ : Percentage difference from base level

* $(+)$ reflects a depreciation of the US\$

** $(+)$ reflects an appreciation 


\section{Table 3.9a}

A reduction in domestic spending in the United States, United Kingdom and Japan over 8 quarters, (equal to the size of two times the standard error of the relevant estimated model equations)

Cumulated effects in percentages, unless stated otherwise

Euro Area

Effects

Real gross domestic product (GDP)

Private consumption

Business investment

Housing investment

Exports

Imports

Output gap

Business employment

Unemployment (\% of labour force)

Labour productivity per person

Compensation per employee

Unit labour cost

Private consumption deflator

Export deflator

Import deflator

GDP deflator

Inflation (private consumption deflator)

\begin{tabular}{|c|c|c|c|c|c|}
\hline Year 1 & Year 2 & Year 3 & $\underline{\text { Year } 4}$ & $\underline{\text { Year } 5}$ & Year 6 \\
\hline-0.07 & -0.17 & -0.20 & -0.17 & -0.13 & -0.10 \\
\hline 0.00 & 0.01 & 0.01 & 0.01 & 0.02 & 0.04 \\
\hline-0.08 & -0.16 & -0.16 & -0.03 & 0.13 & 0.24 \\
\hline 0.01 & 0.06 & 0.15 & 0.23 & 0.28 & 0.30 \\
\hline-0.16 & -0.53 & -0.77 & -0.82 & -0.81 & -0.80 \\
\hline 0.00 & -0.16 & -0.34 & -0.43 & -0.43 & -0.40 \\
\hline-0.09 & -0.20 & -0.22 & -0.18 & -0.13 & -0.10 \\
\hline-0.01 & -0.07 & -0.13 & -0.14 & -0.12 & -0.08 \\
\hline 0.01 & 0.06 & 0.10 & 0.11 & 0.09 & 0.06 \\
\hline-0.06 & -0.10 & -0.08 & -0.03 & -0.01 & -0.01 \\
\hline-0.02 & -0.14 & -0.28 & -0.43 & -0.59 & -0.78 \\
\hline 0.05 & -0.03 & -0.20 & -0.40 & -0.59 & -0.77 \\
\hline-0.01 & -0.07 & -0.17 & -0.31 & -0.48 & -0.67 \\
\hline-0.06 & -0.11 & -0.18 & -0.27 & -0.42 & -0.62 \\
\hline-0.15 & -0.26 & -0.28 & -0.23 & -0.23 & -0.29 \\
\hline-0.01 & -0.06 & -0.14 & -0.27 & -0.44 & -0.62 \\
\hline-0.01 & -0.06 & -0.10 & -0.14 & -0.17 & -0.19 \\
\hline-0.16 & -0.31 & -0.35 & -0.36 & -0.44 & -0.59 \\
\hline-0.04 & -0.17 & -0.31 & -0.45 & -0.58 & -0.72 \\
\hline-0.03 & -0.11 & -0.17 & -0.21 & -0.26 & -0.32 \\
\hline 0.05 & 0.12 & 0.16 & 0.15 & 0.14 & 0.13 \\
\hline 0.01 & 0.03 & 0.05 & 0.08 & 0.10 & 0.12 \\
\hline-0.09 & -0.24 & -0.31 & -0.34 & -0.35 & -0.36 \\
\hline-0.07 & -0.21 & -0.29 & -0.33 & -0.35 & -0.36 \\
\hline-0.85 & -0.82 & -0.44 & -0.02 & 0.25 & 0.43 \\
\hline 0.00 & 0.00 & 0.00 & 0.00 & 0.00 & 0.00 \\
\hline 0.00 & 0.06 & 0.16 & 0.22 & 0.18 & 0.02 \\
\hline 0.03 & 0.12 & 0.15 & 0.12 & 0.05 & -0.05 \\
\hline-0.02 & 0.04 & 0.29 & 0.76 & 1.34 & 1.94 \\
\hline-0.01 & -0.15 & -0.39 & -0.73 & -1.15 & -1.67 \\
\hline 0.68 & 0.75 & 0.37 & -0.28 & -0.85 & -1.18 \\
\hline-0.39 & -0.74 & -0.82 & -0.71 & -0.60 & -0.55 \\
\hline-0.24 & -0.28 & -0.45 & -0.78 & -1.14 & -1.40 \\
\hline-0.24 & -0.29 & -0.43 & -0.71 & -1.03 & -1.28 \\
\hline
\end{tabular}

Cash flow

Personal disposable income

Trade balance (\% GDP)

Government debt (\% GDP)

Government financial balance (\% GDP)

Short-term interest rate (percentage points)

Long-term interest rate (percentage points)

Exchange rate (euro per US\$)*

Share price index

House price index

M3

Bank loans

Net wealth private sector

Effective exchange rate **

World trade volume

Weighted export price

Weighted import price

$-0.29$

$-0.43$

$-0.71$

$-1.03$

$-1.28$

\footnotetext{
A: Absolute difference from base level

$\mathrm{P}$ : Percentage difference from base level

* $(+)$ reflects a depreciation of the euro

** $(+)$ reflects an appreciation
} 


\section{Table 3.9b}

A reduction in domestic spending in the United States, United Kingdom and Japan over 8 quarters, (equal to the size of two times the standard error of the relevant estimated model equations)

Cumulated effects in percentages, unless stated otherwise

\section{United States}

Effects

Real gross domestic product (GDP)

Private consumption

Business investment

Housing investment

Exports

Imports

Output gap

Business employment

Unemployment (\% of labour force)

Labour productivity per person

Compensation per employee

Unit labour cost

Private consumption deflator

Export deflator

Import deflator

GDP deflator

Inflation (private consumption deflator)

Cash flow

Personal disposable income

Trade balance (\% GDP)

Government debt (\% GDP)

Government financial balance (\% GDP)

Short-term interest rate (percentage points)

Long-term interest rate (percentage points)

Exchange rate (US\$ per euro)

Share price index

House price index

M3

Bank loans

Net wealth private sector

Effective exchange rate **

World trade volume

Weighted export price

Weighted import price

\begin{tabular}{|c|c|c|c|c|c|}
\hline Year 1 & Year 2 & Year 3 & Year 4 & Year 5 & Year 6 \\
\hline-1.11 & -1.06 & -0.79 & -0.47 & -0.30 & -0.24 \\
\hline-1.10 & -1.10 & -0.92 & -0.72 & -0.57 & -0.46 \\
\hline-2.70 & -2.70 & -1.90 & -0.72 & 0.00 & 0.27 \\
\hline-2.70 & -2.70 & -1.77 & -0.57 & -0.28 & -0.34 \\
\hline-0.03 & -0.27 & -0.53 & -0.80 & -1.11 & -1.39 \\
\hline-1.28 & -1.97 & -1.91 & -1.49 & -1.15 & -0.94 \\
\hline-1.16 & -0.97 & -0.56 & -0.18 & -0.01 & 0.01 \\
\hline-0.65 & -0.79 & -0.63 & -0.36 & -0.17 & -0.08 \\
\hline 0.53 & 0.64 & 0.51 & 0.29 & 0.14 & 0.06 \\
\hline-0.54 & -0.33 & -0.18 & -0.11 & -0.12 & -0.15 \\
\hline-0.27 & -0.72 & -1.13 & -1.39 & -1.60 & -1.80 \\
\hline 0.28 & -0.39 & -0.95 & -1.28 & -1.49 & -1.65 \\
\hline-0.06 & -0.35 & -0.68 & -1.00 & -1.28 & -1.51 \\
\hline 0.06 & 0.01 & -0.32 & -0.83 & -1.38 & -1.85 \\
\hline 0.05 & 0.18 & 0.25 & 0.11 & -0.21 & -0.62 \\
\hline-0.04 & -0.27 & -0.60 & -0.92 & -1.21 & -1.46 \\
\hline-0.06 & -0.29 & -0.33 & -0.32 & -0.29 & -0.23 \\
\hline-1.65 & -1.24 & -0.95 & -0.88 & -1.09 & -1.39 \\
\hline-0.42 & -0.89 & -1.37 & -1.68 & -1.90 & -2.03 \\
\hline 0.18 & 0.24 & 0.18 & 0.06 & -0.02 & -0.07 \\
\hline 0.93 & 1.19 & 1.19 & 1.02 & 0.87 & 0.84 \\
\hline-0.24 & -0.13 & 0.06 & 0.20 & 0.25 & 0.18 \\
\hline-0.94 & -1.09 & -0.84 & -0.53 & -0.37 & -0.28 \\
\hline-0.80 & -1.01 & -0.85 & -0.58 & -0.41 & -0.31 \\
\hline 0.85 & 0.83 & 0.44 & 0.02 & -0.25 & -0.43 \\
\hline 0.00 & 0.00 & 0.00 & 0.00 & 0.00 & 0.00 \\
\hline 0.57 & 0.58 & 0.05 & -0.71 & -1.30 & -1.67 \\
\hline 0.02 & -0.23 & -0.70 & -1.29 & -1.84 & -2.29 \\
\hline-0.56 & -0.04 & 2.14 & 5.35 & 7.98 & 9.53 \\
\hline 0.79 & 2.12 & 2.89 & 2.83 & 2.22 & 1.51 \\
\hline-0.77 & -0.84 & -0.70 & -0.65 & -0.76 & -0.90 \\
\hline-0.38 & -0.99 & -1.29 & -1.33 & -1.36 & -1.37 \\
\hline 0.77 & 0.70 & -0.10 & -1.26 & -2.16 & -2.66 \\
\hline 0.72 & 0.65 & -0.07 & -1.09 & -1.90 & -2.38 \\
\hline
\end{tabular}

A: Absolute difference from base level

$\mathrm{P}$ : Percentage difference from base level

* $(+)$ reflects a depreciation of the US\$

** $(+)$ reflects an appreciation 
Table 3.10

Autonomous increase in annual inflation in the euro area by 1 percentage point over 4 quarters Cumulated effects in percentages, unless stated otherwise

\section{Euro Area}

Effects

Private consumption

Business investment

Housing investment

Exports

Imports

Output gap

Business employment

Unemployment (\% of labour force)

Labour productivity per person

Compensation per employee

Unit labour cost

Private consumption deflator

Export deflator

Import deflator

GDP deflator

Inflation (private consumption deflator)

Cash flow

Personal disposable income

Trade balance (\% GDP)

Government debt (\% GDP)

Short-term interest rate (percentage points)

Exchange rate (euro per US\$)*

Share price index

House price index

M3

Bank loans

Net wealth private sector

Effective exchange rate **

World trade volume

Weighted export price

Weighted import price
Real gross domestic product (GDP)

Government financial balance (\% GDP)

Long-term interest rate (percentage points)

$\begin{array}{rrrrrrr}\text { Year 1 } & \text { Year 2 } & \text { Year 3 } & \text { Year 4 } & \text { Year 5 } & \text { Year 6 } & \\ -0.18 & -0.38 & -0.37 & -0.36 & -0.29 & -0.21 & \mathrm{P} \\ -0.16 & -0.49 & -0.48 & -0.46 & -0.38 & -0.26 & \mathrm{P} \\ -0.30 & -0.72 & -0.72 & -0.64 & -0.45 & -0.21 & \mathrm{P} \\ -0.08 & -0.26 & -0.40 & -0.47 & -0.43 & -0.30 & \mathrm{P} \\ -0.11 & -0.12 & -0.22 & -0.30 & -0.34 & -0.35 & \mathrm{P} \\ 0.00 & -0.19 & -0.34 & -0.40 & -0.41 & -0.35 & \mathrm{P} \\ & & & & & & \\ -0.19 & -0.37 & -0.33 & -0.29 & -0.20 & -0.10 & \mathrm{~A} \\ 0.05 & -0.06 & -0.14 & -0.19 & -0.20 & -0.18 & \mathrm{P} \\ -0.04 & 0.05 & 0.11 & 0.15 & 0.15 & 0.13 & \mathrm{~A} \\ -0.24 & -0.34 & -0.25 & -0.17 & -0.09 & -0.02 & \mathrm{P} \\ & & & & & & \\ 0.66 & 1.06 & 1.30 & 1.38 & 1.37 & 1.28 & \mathrm{P} \\ 0.90 & 1.41 & 1.55 & 1.56 & 1.45 & 1.28 & \mathrm{P} \\ 1.00 & 1.31 & 1.56 & 1.61 & 1.51 & 1.31 & \mathrm{P} \\ 0.15 & 0.48 & 0.77 & 0.96 & 1.01 & 0.97 & \mathrm{P} \\ -0.22 & -0.08 & 0.17 & 0.42 & 0.65 & 0.81 & \mathrm{P} \\ 0.76 & 1.20 & 1.48 & 1.59 & 1.52 & 1.35 & \mathrm{P} \\ 1.00 & 0.31 & 0.25 & 0.05 & -0.11 & -0.19 & \mathrm{~A} \\ & & & & & & \\ 0.37 & 0.60 & 1.04 & 1.27 & 1.34 & 1.28 & \mathrm{P} \\ 0.51 & 0.66 & 0.86 & 0.90 & 0.92 & 0.89 & \mathrm{P} \\ & & & & & & \\ 0.08 & 0.20 & 0.24 & 0.22 & 0.17 & 0.09 & \mathrm{~A} \\ -0.14 & -0.08 & -0.12 & -0.14 & -0.18 & -0.31 & \mathrm{~A} \\ -0.28 & -0.23 & -0.16 & -0.07 & 0.03 & 0.19 & \mathrm{~A} \\ & & & & & & \\ 1.35 & 0.18 & 0.12 & -0.14 & -0.31 & -0.37 & \mathrm{~A} \\ 1.16 & 0.26 & 0.17 & -0.08 & -0.26 & -0.34 & \mathrm{~A} \\ -1.24 & 0.10 & 0.34 & 0.77 & 1.05 & 1.18 & \mathrm{P} \\ -8.33 & -4.11 & -2.33 & 1.21 & 4.34 & 6.09 & \mathrm{P} \\ 0.57 & 0.65 & 1.08 & 1.37 & 1.52 & 1.49 & \mathrm{P} \\ -0.10 & 0.25 & 0.72 & 1.18 & 1.61 & 1.89 & \mathrm{P} \\ -0.02 & -0.93 & -1.42 & -1.65 & -1.44 & -0.85 & \mathrm{P} \\ 0.22 & 0.80 & 1.34 & 1.77 & 2.02 & 2.00 & \mathrm{P} \\ 0.94 & -0.10 & -0.28 & -0.56 & -0.75 & -0.83 & \mathrm{P} \\ 0.00 & -0.13 & -0.25 & -0.32 & -0.34 & -0.29 & \mathrm{P} \\ -0.49 & 0.32 & 0.57 & 0.86 & 1.03 & 1.06 & \mathrm{P} \\ -0.45 & 0.32 & 0.58 & 0.87 & 1.03 & 1.07 & \mathrm{P} \\ & & & & & & \end{array}$

A: Absolute difference from base level

$P$ : Percentage difference from base level

* $(+)$ reflects a depreciation of the euro

** $(+)$ reflects an appreciation 


\section{Table 3.11a}

Reduction in house prices in the euro area by $10 \%$ over 8 quarters Cumulated effects in percentages, unless stated otherwise

\section{Euro Area}

Effects

Real gross domestic product (GDP)

Private consumption

Business investment

Housing investment

Exports

Imports

Output gap

Business employment

Unemployment (\% of labour force)

Labour productivity per person

Compensation per employee

Unit labour cost

Private consumption deflator

Export deflator

Import deflator

GDP deflator

Inflation (private consumption deflator)

Cash flow

Personal disposable income

Trade balance (\% GDP)

Government debt (\% GDP)

Government financial balance (\% GDP)

Short-term interest rate (percentage points)

Long-term interest rate (percentage points)

Exchange rate (euro per US\$)*

Share price index

M3

Bank loans

Net wealth private sector

Effective exchange rate **

World trade volume

Weighted export price

Weighted import price
House price index

\begin{tabular}{|c|c|c|c|c|c|}
\hline Year 1 & Year 2 & Year 3 & Year 4 & Year 5 & Year 6 \\
\hline-0.02 & -0.05 & -0.09 & -0.11 & -0.11 & -0.09 \\
\hline-0.03 & -0.11 & -0.19 & -0.23 & -0.24 & -0.20 \\
\hline-0.01 & -0.05 & -0.09 & -0.08 & -0.05 & 0.01 \\
\hline 0.00 & 0.02 & 0.04 & 0.06 & 0.07 & 0.07 \\
\hline 0.00 & -0.01 & -0.04 & -0.07 & -0.10 & -0.11 \\
\hline 0.00 & -0.05 & -0.12 & -0.18 & -0.21 & -0.19 \\
\hline-0.02 & -0.05 & -0.08 & -0.10 & -0.09 & -0.06 \\
\hline 0.00 & -0.01 & -0.02 & -0.04 & -0.04 & -0.03 \\
\hline 0.00 & 0.01 & 0.02 & 0.03 & 0.03 & 0.02 \\
\hline-0.02 & -0.05 & -0.07 & -0.08 & -0.07 & -0.05 \\
\hline 0.00 & -0.02 & -0.03 & -0.05 & -0.08 & -0.11 \\
\hline 0.01 & 0.03 & 0.04 & 0.03 & -0.01 & -0.06 \\
\hline 0.00 & 0.00 & 0.00 & 0.01 & 0.00 & -0.03 \\
\hline 0.00 & 0.00 & 0.02 & 0.03 & 0.03 & 0.01 \\
\hline 0.00 & 0.01 & 0.01 & 0.02 & 0.03 & 0.04 \\
\hline 0.00 & 0.00 & 0.01 & 0.01 & 0.01 & -0.01 \\
\hline 0.00 & 0.00 & 0.01 & 0.01 & -0.01 & -0.03 \\
\hline-0.03 & -0.08 & -0.10 & -0.08 & -0.05 & -0.02 \\
\hline-0.01 & -0.02 & -0.05 & -0.08 & -0.10 & -0.13 \\
\hline 0.00 & 0.01 & 0.02 & 0.03 & 0.02 & 0.01 \\
\hline 0.01 & 0.05 & 0.08 & 0.10 & 0.10 & 0.08 \\
\hline 0.00 & -0.01 & -0.01 & -0.01 & 0.00 & 0.02 \\
\hline-0.01 & -0.04 & -0.05 & -0.06 & -0.08 & -0.10 \\
\hline-0.01 & -0.04 & -0.05 & -0.06 & -0.07 & -0.09 \\
\hline 0.01 & 0.04 & 0.05 & 0.06 & 0.07 & 0.09 \\
\hline 0.08 & 0.33 & 0.52 & 0.70 & 0.95 & 1.26 \\
\hline-10.00 & -10.00 & -8.20 & -4.63 & -1.25 & 0.93 \\
\hline 0.01 & 0.05 & 0.10 & 0.15 & 0.20 & 0.24 \\
\hline 0.00 & 0.01 & 0.05 & 0.12 & 0.23 & 0.35 \\
\hline 0.00 & 0.02 & 0.05 & 0.10 & 0.13 & 0.14 \\
\hline-0.01 & -0.03 & -0.03 & -0.04 & -0.05 & -0.06 \\
\hline 0.00 & -0.03 & -0.08 & -0.12 & -0.14 & -0.13 \\
\hline 0.01 & 0.02 & 0.03 & 0.04 & 0.05 & 0.04 \\
\hline 0.01 & 0.02 & 0.03 & 0.04 & 0.04 & 0.04 \\
\hline
\end{tabular}

A: Absolute difference from base level

$P$ : Percentage difference from base level

* $(+)$ reflects a depreciation of the euro

** $(+)$ reflects an appreciation 


\section{Table 3.11b}

Reduction in house prices in the United States by $10 \%$ over 8 quarters

Cumulated effects in percentages, unless stated otherwise

\section{United States}

Effects

Real gross domestic product (GDP)

Private consumption

Business investment

Housing investment

Exports

Imports

Output gap

Business employment

Unemployment (\% of labour force)

Labour productivity per person

Compensation per employee

Unit labour cost

Private consumption deflator

Export deflator

Import deflator

GDP deflator

Inflation (private consumption deflator)

Cash flow

Personal disposable income

Trade balance (\% GDP)

Government debt (\% GDP)

Government financial balance (\% GDP)

Short-term interest rate (percentage points)

Long-term interest rate (percentage points)

Exchange rate (US\$ per euro)*

Share price index

House price index

M3

Bank loans

Net wealth private sector

Effective exchange rate **

World trade volume

Weighted export price

Weighted import price $\underline{\text { Year } 1} \underline{\text { Year } 2} \underline{\text { Year } 3} \underline{\text { Year } 4} \underline{\text { Year } 5} \underline{\text { Year } 6}$

$\begin{array}{lllllll}-0.10 & -0.26 & -0.30 & -0.24 & -0.16 & -0.08 & P\end{array}$

$\begin{array}{lllllll}-0.12 & -0.35 & -0.44 & -0.42 & -0.35 & -0.27 & P\end{array}$

$\begin{array}{rrrrrrr}-0.15 & -0.47 & -0.52 & -0.31 & -0.02 & 0.21 & \mathrm{P} \\ 0.01 & 0.08 & 0.17 & 0.19 & 0.13 & 0.02 & \mathrm{P}\end{array}$

$\begin{array}{lllllll}0.00 & 0.03 & 0.07 & 0.08 & 0.08 & 0.07 & P\end{array}$

$\begin{array}{lllllll}-0.07 & -0.38 & -0.55 & -0.53 & -0.42 & -0.29 & P\end{array}$

$\begin{array}{lllllll}-0.10 & -0.25 & -0.27 & -0.19 & -0.09 & -0.02 & \text { A }\end{array}$

$\begin{array}{lllllll}-0.05 & -0.16 & -0.20 & -0.17 & -0.10 & -0.03 & P\end{array}$

$\begin{array}{lllllll}0.04 & 0.13 & 0.16 & 0.14 & 0.08 & 0.03 & \text { A }\end{array}$

$\begin{array}{llllll}-0.05 & -0.12 & -0.11 & -0.08 & -0.06 & -0.04\end{array}$

$\begin{array}{lllllll}-0.01 & -0.09 & -0.19 & -0.25 & -0.29 & -0.32 & P\end{array}$

$\begin{array}{lllllll}0.04 & 0.02 & -0.08 & -0.17 & -0.24 & -0.28 & P\end{array}$

$\begin{array}{lllllll}0.04 & 0.02 & -0.08 & -0.17 & -0.24 & -0.28 & \mathrm{P} \\ 0.00 & -0.03 & -0.06 & -0.11 & -0.16 & -0.22 & \mathrm{P}\end{array}$

$\begin{array}{llllll}0.00 & 0.02 & 0.01 & -0.02 & -0.08 & -0.15\end{array}$

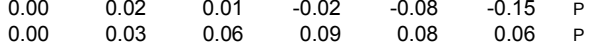

$\begin{array}{lllllll}0.00 & -0.02 & -0.06 & -0.10 & -0.15 & -0.20 & P\end{array}$

$\begin{array}{llllll}0.00 & -0.02 & -0.04 & -0.05 & -0.05 & -0.05\end{array}$

$\begin{array}{lllllll}-0.16 & -0.33 & -0.32 & -0.23 & -0.16 & -0.14 & P\end{array}$

$\begin{array}{lllllll}-0.03 & -0.11 & -0.20 & -0.28 & -0.34 & -0.37 & P\end{array}$

$\begin{array}{lllllll}0.01 & 0.06 & 0.08 & 0.07 & 0.05 & 0.03 & \text { A }\end{array}$

$\begin{array}{lllllll}0.08 & 0.24 & 0.33 & 0.33 & 0.27 & 0.19 & \text { A }\end{array}$

$\begin{array}{lllllll}-0.02 & -0.05 & -0.04 & 0.00 & 0.04 & 0.07 & \text { A }\end{array}$

$\begin{array}{lllllll}-0.08 & -0.22 & -0.25 & -0.20 & -0.13 & -0.08 & A\end{array}$

$\begin{array}{lllllll}-0.06 & -0.20 & -0.23 & -0.20 & -0.15 & -0.09 & \text { A }\end{array}$

$\begin{array}{lllllll}0.08 & 0.20 & 0.21 & 0.14 & 0.07 & 0.00 & P\end{array}$

$\begin{array}{rrrrrrr}0.27 & 1.37 & 2.26 & 2.02 & 1.69 & 1.28 & P\end{array}$

$\begin{array}{lllllll}-10.00 & -10.00 & -8.14 & -5.48 & -3.75 & -2.66 & P\end{array}$

$\begin{array}{lllllll}0.02 & 0.02 & 0.02 & -0.01 & -0.07 & -0.14 & P\end{array}$

$\begin{array}{rrrrrrr}0.02 & 0.02 & 0.02 & -0.01 & -0.07 & -0.14 & \mathrm{P} \\ -0.02 & -0.03 & 0.25 & 0.86 & 1.53 & 2.06 & \mathrm{P} \\ 0.04 & 0.32 & 0.70 & 1.01 & 1.12 & 1.07 & \mathrm{P}\end{array}$

$\begin{array}{lllllll}0.04 & 0.32 & 0.70 & 1.01 & 1.12 & 1.07 & P\end{array}$

$\begin{array}{lllllll}-0.08 & -0.20 & -0.20 & -0.13 & -0.05 & 0.01 & P\end{array}$

$\begin{array}{lllllll}0.00 & 0.00 & 0.00 & -0.01 & -0.02 & -0.02 & P\end{array}$

$\begin{array}{lllllll}0.08 & 0.20 & 0.19 & 0.11 & 0.01 & -0.07 & P\end{array}$

A: Absolute difference from base level

P: Percentage difference from base level

* $(+)$ reflects a depreciation of the US\$

** (+) reflects an appreciation 
Table 3.12a

Worldwide fall in share prices by $\mathbf{2 5 \%}$ over $\mathbf{8}$ quarters

Cumulated effects in percentages, unless stated otherwise

\begin{tabular}{|c|c|c|c|c|c|c|}
\hline Effects & $\underline{\text { Year } 1}$ & Year 2 & Year 3 & Year 4 & $\underline{\text { Year } 5}$ & Year 6 \\
\hline Real gross domestic product (GDP) & -0.04 & -0.20 & -0.37 & -0.46 & -0.43 & -0.33 \\
\hline Private consumption & -0.06 & -0.24 & -0.42 & -0.52 & -0.51 & -0.43 \\
\hline Business investment & -0.03 & -0.21 & -0.40 & -0.41 & -0.20 & 0.13 \\
\hline Housing investment & -0.01 & -0.07 & -0.14 & -0.16 & -0.10 & 0.02 \\
\hline Exports & -0.01 & -0.20 & -0.55 & -0.89 & -1.08 & -1.09 \\
\hline Imports & -0.01 & -0.13 & -0.42 & -0.74 & -0.94 & -0.94 \\
\hline Output gap & -0.04 & -0.21 & -0.37 & -0.45 & -0.39 & -0.28 \\
\hline Business employment & -0.01 & -0.05 & -0.14 & -0.23 & -0.26 & -0.23 \\
\hline Unemployment (\% of labour force) & 0.00 & 0.04 & 0.11 & 0.17 & 0.20 & 0.17 \\
\hline Labour productivity per person & -0.03 & -0.16 & -0.25 & -0.25 & -0.18 & -0.10 \\
\hline Compensation per employee & 0.00 & -0.07 & -0.21 & -0.42 & -0.66 & -0.92 \\
\hline Unit labour cost & 0.03 & 0.09 & 0.04 & -0.17 & -0.49 & -0.82 \\
\hline Private consumption deflator & 0.00 & -0.01 & -0.04 & -0.14 & -0.33 & -0.59 \\
\hline Export deflator & -0.01 & -0.04 & -0.08 & -0.11 & -0.18 & -0.35 \\
\hline Import deflator & -0.03 & -0.19 & -0.30 & -0.31 & -0.23 & -0.16 \\
\hline GDP deflator & 0.00 & -0.01 & -0.04 & -0.12 & -0.29 & -0.53 \\
\hline Inflation (private consumption deflator) & 0.00 & -0.01 & -0.03 & -0.10 & -0.19 & -0.26 \\
\hline Cash flow & -0.06 & -0.31 & -0.49 & -0.54 & -0.51 & -0.55 \\
\hline Personal disposable income & -0.25 & -0.75 & -0.94 & -1.01 & -0.98 & -1.11 \\
\hline Trade balance (\% GDP) & 0.01 & 0.00 & -0.02 & -0.07 & -0.13 & -0.22 \\
\hline Government debt ( $\%$ GDP) & 0.05 & 0.25 & 0.45 & 0.57 & 0.57 & 0.50 \\
\hline Government financial balance ( $\%$ GDP) & -0.03 & -0.07 & -0.06 & 0.01 & 0.10 & 0.18 \\
\hline Short-term interest rate (percentage points) & -0.03 & -0.17 & -0.33 & -0.49 & -0.58 & -0.60 \\
\hline Long-term interest rate (percentage points) & -0.03 & -0.15 & -0.29 & -0.45 & -0.55 & -0.59 \\
\hline Exchange rate (euro per US\$) ${ }^{*}$ & -0.32 & -0.94 & -1.14 & -0.85 & -0.31 & 0.13 \\
\hline Share price index & -25.00 & -25.00 & -20.34 & -7.81 & 0.00 & 0.00 \\
\hline House price index & -0.03 & -0.17 & -0.18 & 0.00 & 0.24 & 0.36 \\
\hline M3 & -0.54 & -1.22 & -1.13 & -0.54 & 0.06 & 0.18 \\
\hline Bank loans & 0.00 & 0.02 & 0.17 & 0.63 & 1.41 & 2.42 \\
\hline Net wealth private sector & 0.02 & 0.10 & 0.17 & 0.13 & -0.08 & -0.50 \\
\hline Effective exchange rate ** & 0.12 & 0.37 & 0.47 & 0.31 & -0.03 & -0.38 \\
\hline World trade volume & -0.06 & -0.43 & -0.86 & -1.16 & -1.19 & -1.07 \\
\hline Weighted export price & -0.06 & -0.17 & -0.21 & -0.19 & -0.22 & -0.41 \\
\hline Weighted import price & -0.06 & -0.17 & -0.22 & -0.20 & -0.22 & -0.40 \\
\hline
\end{tabular}

A: Absolute difference from base level

$\mathrm{P}$ : Percentage difference from base level

* (+) reflects a depreciation of the euro

** $(+)$ reflects an appreciation 


\section{Table 3.12b}

Worldwide fall in share prices by $25 \%$ over 8 quarters

Cumulated effects in percentages, unless stated otherwise

\begin{tabular}{|c|c|c|c|c|c|c|}
\hline Effects & Year 1 & Year 2 & Year 3 & Year 4 & Year 5 & $\underline{\text { Year } 6}$ \\
\hline Real gross domestic product (GDP) & -0.43 & -1.31 & -1.83 & -1.77 & -1.23 & -0.71 \\
\hline Private consumption & -0.54 & -1.72 & -2.55 & -2.73 & -2.28 & -1.76 \\
\hline Business investment & -0.68 & -2.36 & -3.18 & -2.59 & -0.83 & 0.83 \\
\hline Housing investment & 0.01 & 0.14 & 0.36 & 0.45 & 0.23 & -0.23 \\
\hline Exports & 0.01 & 0.07 & 0.10 & 0.05 & -0.10 & -0.32 \\
\hline Imports & -0.32 & -1.85 & -3.11 & -3.53 & -2.95 & -2.10 \\
\hline Output gap & -0.46 & -1.31 & -1.71 & -1.51 & -0.85 & -0.32 \\
\hline Business employment & -0.22 & -0.80 & -1.19 & -1.20 & -0.84 & -0.41 \\
\hline Unemployment (\% of labour force) & 0.18 & 0.65 & 0.96 & 0.98 & 0.69 & 0.34 \\
\hline Labour productivity per person & -0.24 & -0.60 & -0.74 & -0.65 & -0.41 & -0.29 \\
\hline Compensation per employee & -0.06 & -0.45 & -0.98 & -1.44 & -1.73 & -1.92 \\
\hline Unit labour cost & 0.19 & 0.15 & -0.24 & -0.80 & -1.32 & -1.63 \\
\hline Private consumption deflator & -0.01 & -0.12 & -0.30 & -0.54 & -0.85 & -1.19 \\
\hline Export deflator & 0.01 & 0.09 & 0.10 & -0.02 & -0.31 & -0.76 \\
\hline Import deflator & 0.01 & 0.12 & 0.32 & 0.49 & 0.53 & 0.40 \\
\hline GDP deflator & 0.00 & -0.09 & -0.26 & -0.48 & -0.77 & -1.11 \\
\hline Inflation (private consumption deflator) & -0.01 & -0.11 & -0.18 & -0.24 & -0.31 & -0.35 \\
\hline Cash flow & -0.71 & -1.73 & -2.09 & -1.76 & -1.13 & -0.94 \\
\hline Personal disposable income & -0.35 & -1.24 & -1.93 & -2.39 & -2.56 & -2.73 \\
\hline Trade balance (\% GDP) & 0.05 & 0.27 & 0.44 & 0.47 & 0.35 & 0.18 \\
\hline Government debt (\% GDP) & 0.39 & 1.33 & 2.13 & 2.40 & 2.08 & 1.59 \\
\hline Government financial balance (\% GDP) & -0.13 & -0.35 & -0.35 & -0.13 & 0.21 & 0.43 \\
\hline Short-term interest rate (percentage points) & -0.35 & -1.12 & -1.51 & -1.43 & -1.03 & -0.68 \\
\hline Long-term interest rate (percentage points) & -0.29 & -0.99 & -1.40 & -1.40 & -1.08 & -0.75 \\
\hline Exchange rate (US\$ per euro)* & 0.32 & 0.95 & 1.15 & 0.86 & 0.31 & -0.13 \\
\hline Share price index & -25.00 & -25.00 & -20.34 & -7.81 & 0.00 & 0.00 \\
\hline House price index & 0.14 & 0.42 & 0.26 & -0.39 & -1.37 & -2.31 \\
\hline M3 & -0.14 & -0.62 & -1.16 & -1.62 & -1.95 & -2.26 \\
\hline Bank loans & -0.10 & -0.14 & 1.39 & 5.57 & 11.19 & 16.33 \\
\hline Net wealth private sector & 0.23 & 1.73 & 4.10 & 6.35 & 7.45 & 7.20 \\
\hline Effective exchange rate ${ }^{* *}$ & -0.32 & -0.99 & -1.26 & -1.09 & -0.69 & -0.40 \\
\hline World trade volume & -0.02 & -0.22 & -0.49 & -0.76 & -0.96 & -1.10 \\
\hline Weighted export price & 0.32 & 0.98 & 1.22 & 0.94 & 0.25 & -0.53 \\
\hline Weighted import price & 0.32 & 0.95 & 1.17 & 0.89 & 0.22 & -0.51 \\
\hline
\end{tabular}

A: Absolute difference from base level

$\mathrm{P}$ : Percentage difference from base level

* (+) reflects a depreciation of the US\$

** $(+)$ reflects an appreciation 
Table 3.12c

Worldwide fall in share prices by $25 \%$ over 8 quarters accompanied by an increase in the external financing cost rate for firms by 1 percentage point

Cumulated effects in percentages, unless stated otherwise

Euro Area

Effects

Real gross domestic product (GDP)

Private consumption

Business investment

Housing investment

Exports

Imports

Output gap

Business employment

Unemployment (\% of labour force)

Labour productivity per person

Compensation per employee

Unit labour cost

Private consumption deflator

Export deflator

Import deflator

GDP deflator

Inflation (private consumption deflator)

Cash flow

Personal disposable income

Trade balance (\% GDP)

Government debt (\% GDP)

Government financial balance (\% GDP)

Short-term interest rate (percentage points)

Long-term interest rate (percentage points)

Exchange rate (euro per US\$)*

Share price index

House price index

M3

Bank loans

Net wealth private sector

Effective exchange rate **

World trade volume

Weighted export price

Weighted import price $\underline{\text { Year } 1} \underline{\text { Year } 2} \underline{\text { Year } 3} \underline{\text { Year } 4} \underline{\text { Year } 5} \underline{\text { Year } 6}$

$\begin{array}{lllllll}-0.24 & -0.84 & -1.23 & -1.24 & -1.10 & -0.91 & P\end{array}$

$\begin{array}{lllllll}-0.06 & -0.25 & -0.50 & -0.72 & -0.73 & -0.61 & P\end{array}$

$\begin{array}{lllllll}-1.69 & -5.55 & -6.90 & -5.02 & -3.27 & -1.96 & P\end{array}$

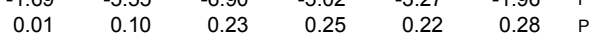

$\begin{array}{lllllll}-0.01 & -0.43 & -1.34 & -2.15 & -2.52 & -2.62 & P\end{array}$

$\begin{array}{lllllll}-0.05 & -0.70 & -1.64 & -2.13 & -2.23 & -2.11 & P\end{array}$

$\begin{array}{lllllll}-0.27 & -0.84 & -1.01 & -0.75 & -0.44 & -0.15 & \text { A }\end{array}$

$\begin{array}{lllllll}-0.04 & -0.28 & -0.60 & -0.76 & -0.72 & -0.55 & P\end{array}$

$\begin{array}{lllllll}0.03 & 0.21 & 0.45 & 0.58 & 0.55 & 0.42 & \text { A }\end{array}$

$\begin{array}{lllllll}-0.22 & -0.62 & -0.70 & -0.51 & -0.37 & -0.30 & P\end{array}$

$\begin{array}{lllllll}-0.03 & -0.31 & -0.79 & -1.45 & -2.27 & -3.21 & P\end{array}$

$\begin{array}{lllllll}0.18 & 0.32 & -0.08 & -0.93 & -1.90 & -2.92 & P\end{array}$

$\begin{array}{lllllll}0.00 & -0.02 & -0.09 & -0.54 & -1.32 & -2.32 & P\end{array}$

$\begin{array}{lllllll}0.00 & -0.03 & -0.06 & -0.23 & -0.75 & -1.60 & P\end{array}$

$\begin{array}{lllllll}-0.03 & -0.16 & -0.33 & -0.34 & -0.31 & -0.46 & P\end{array}$

$\begin{array}{lllllll}-0.01 & -0.03 & -0.08 & -0.44 & -1.15 & -2.09 & P\end{array}$

$\begin{array}{llllll}0.00 & -0.01 & -0.07 & -0.45 & -0.79 & -1.02\end{array}$

$\begin{array}{lllllll}-0.50 & -1.45 & -1.60 & -1.38 & -1.57 & -2.14 & P\end{array}$

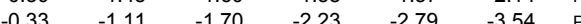

$\begin{array}{lllllll}0.02 & 0.08 & 0.05 & -0.17 & -0.48 & -0.82 & \text { A }\end{array}$

$\begin{array}{lllllll}0.19 & 0.68 & 1.07 & 1.27 & 1.39 & 1.48 & \mathrm{~A}\end{array}$

$\begin{array}{lllllll}-0.02 & -0.04 & -0.05 & 0.07 & 0.30 & 0.48 & \text { A }\end{array}$

$\begin{array}{lllllll}-0.21 & -0.65 & -0.86 & -1.25 & -1.51 & -1.64 & A\end{array}$

$\begin{array}{lllllll}-0.18 & -0.57 & -0.80 & -1.16 & -1.44 & -1.59 & \text { A }\end{array}$

$\begin{array}{lllllll}-0.26 & -0.93 & -1.29 & -0.79 & -0.15 & 0.21 & P\end{array}$

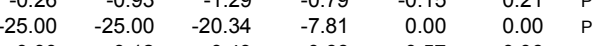

$\begin{array}{lllllll}0.00 & 0.12 & 0.49 & 0.68 & 0.57 & -0.06 & P\end{array}$

$\begin{array}{lllllll}-0.43 & -0.84 & -0.74 & -0.34 & -0.04 & -0.31 & P\end{array}$

$\begin{array}{rrrrrrr}-0.43 & -0.84 & -0.74 & -0.34 & -0.04 & -0.31 & \mathrm{P} \\ -0.12 & -0.33 & 0.12 & 1.66 & 4.15 & 7.44 & \mathrm{P}\end{array}$

$\begin{array}{lllllll}0.02 & 0.14 & 0.29 & 0.19 & -0.52 & -1.88 & P\end{array}$

$\begin{array}{lllllll}0.07 & 0.35 & 0.56 & 0.10 & -0.61 & -1.23 & P\end{array}$

$\begin{array}{lllllll}-0.13 & -1.07 & -2.22 & -2.71 & -2.66 & -2.43 & P\end{array}$

$\begin{array}{lllllll}-0.01 & -0.08 & -0.23 & -2.71 & -2.66 & -2.43 & \mathrm{P} \\ -0.02 & -0.09 & -0.24 & -0.50 & -1.36 & -2.59 & \mathrm{P}\end{array}$

$\begin{array}{lllllll}-0.02 & -0.09 & -0.24 & -0.50 & -1.24 & -2.38 & P\end{array}$

A: Absolute difference from base level

$P$ : Percentage difference from base level

* $(+)$ reflects a depreciation of the euro

** (+) reflects an appreciation 


\section{Table 3.12d}

Worldwide fall in share prices by $25 \%$ over 8 quarters accompanied by an increase in the external financing cost rate for firms by 1 percentage point

Cumulated effects in percentages, unless stated otherwise

\section{United States}

Effects

Real gross domestic product (GDP)

Private consumption

Business investment

Housing investment

Exports

Imports

Output gap

Business employment

Unemployment (\% of labour force)

Labour productivity per person

Compensation per employee

Unit labour cost

Private consumption deflator

Export deflator

Import deflator

GDP deflator

Inflation (private consumption deflator)

Cash flow

Personal disposable income

Trade balance (\% GDP)

Government debt (\% GDP)

Government financial balance (\% GDP)

Short-term interest rate (percentage points)

Long-term interest rate (percentage points)

Exchange rate (US\$ per euro)*

Share price index

House price index

M3

Bank loans

Net wealth private sector

Effective exchange rate **

World trade volume

Weighted export price

Weighted import price $\underline{\text { Year } 1} \underline{\text { Year } 2} \underline{\text { Year } 3} \underline{\text { Year } 4} \underline{\text { Year } 5} \underline{\text { Year } 6}$

$\begin{array}{rrrrrrr}-0.57 & -1.86 & -2.73 & -2.77 & -2.27 & -1.82 & \mathrm{P} \\ -0.54 & -1.75 & -2.70 & -3.04 & -2.73 & -2.34 & \mathrm{P} \\ -1.62 & -6.12 & -8.93 & -7.98 & -5.41 & -3.01 & \mathrm{P} \\ 0.02 & 0.27 & 0.72 & 0.89 & 0.51 & -0.20 & \mathrm{P} \\ 0.01 & -0.13 & -0.60 & -1.34 & -2.27 & -3.33 & \mathrm{P} \\ -0.42 & -2.55 & -4.53 & -5.21 & -4.67 & -3.76 & \mathrm{P}\end{array}$

$\begin{array}{lllllll}-0.61 & -1.87 & -2.49 & -2.17 & -1.40 & -0.84 & \text { A }\end{array}$

$\begin{array}{lllllll}-0.30 & -1.16 & -1.84 & -1.97 & -1.64 & -1.24 & P\end{array}$

$\begin{array}{lllllll}0.25 & 0.95 & 1.50 & 1.60 & 1.34 & 1.01 & \mathrm{~A}\end{array}$

$\begin{array}{lllllll}-0.31 & -0.83 & -1.05 & -0.93 & -0.71 & -0.62 & P\end{array}$

$\begin{array}{lllllll}-0.08 & -0.62 & -1.45 & -2.19 & -2.81 & -3.40 & P\end{array}$

$\begin{array}{lllllll}0.24 & 0.21 & -0.40 & -1.27 & -2.12 & -2.79 & P\end{array}$

$\begin{array}{rrrrrrr}0.24 & 0.21 & -0.40 & -1.27 & -2.12 & -2.79 & \mathrm{P} \\ -0.01 & -0.17 & -0.44 & -0.85 & -1.42 & -2.12 & \mathrm{P}\end{array}$

$\begin{array}{lllllll}0.02 & 0.10 & 0.08 & -0.22 & -0.99 & -2.17 & P\end{array}$

$\begin{array}{lllllll}0.01 & 0.13 & 0.37 & 0.53 & 0.34 & -0.27 & P\end{array}$

$\begin{array}{lllllll}-0.01 & -0.12 & -0.37 & -0.74 & -1.27 & -1.94 & P\end{array}$

$\begin{array}{llllll}-0.01 & -0.16 & -0.28 & -0.41 & -0.58 & -0.71\end{array}$

$\begin{array}{lllllll}-0.96 & -2.56 & -3.26 & -2.95 & -2.47 & -2.60 & P\end{array}$

$\begin{array}{llllll}-0.39 & -1.49 & -2.53 & -3.36 & -3.98 & -4.68\end{array}$

$\begin{array}{lllllll}0.06 & 0.36 & 0.58 & 0.58 & 0.37 & 0.12 & \text { A }\end{array}$

$\begin{array}{lllllll}0.06 & 0.36 & 0.58 & 0.58 & 0.37 & 0.12 & A \\ 0.50 & 1.80 & 3.02 & 3.56 & 3.46 & 3.21 & A\end{array}$

$\begin{array}{rrrrrrr}0.50 & 1.80 & 3.02 & 3.56 & 3.46 & 3.21 & \text { A } \\ -0.16 & -0.44 & -0.47 & -0.22 & 0.19 & 0.46 & \text { A }\end{array}$

$\begin{array}{lllllll}-0.47 & -1.60 & -2.22 & -2.14 & -1.77 & -1.52 & \text { A }\end{array}$

$\begin{array}{lllllll}-0.39 & -1.40 & -2.05 & -2.09 & -1.81 & -1.56 & \text { A }\end{array}$

$\begin{array}{lllllll}0.26 & 0.94 & 1.31 & 0.80 & 0.15 & -0.21 & P\end{array}$

$\begin{array}{rrrrrrr}-25.00 & -25.00 & -20.34 & -7.81 & 0.00 & 0.00 & P\end{array}$

$\begin{array}{rrrrrrr}0.19 & 0.66 & 0.59 & -0.35 & -1.80 & -3.30 & P\end{array}$

$\begin{array}{llllll}0.19 & 0.66 & 0.59 & -0.35 & -1.80 & -3.30 \\ -0.11 & -0.59 & -1.24 & -2.00 & -2.78 & -3.69\end{array}$

$\begin{array}{rrrrrrr}-0.11 & -0.59 & -1.24 & -2.00 & -2.78 & -3.69 & P \\ -0.24 & -0.81 & 0.97 & 8.04 & 18.43 & 28.90 & P\end{array}$

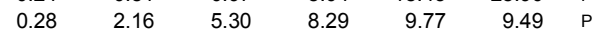

$\begin{array}{lllllll}-0.36 & -1.22 & -1.74 & -1.76 & -1.79 & -2.15 & P\end{array}$

$\begin{array}{rrrrrrr}-0.08 & -0.84 & -2.13 & -3.19 & -3.85 & -4.27 & P \\ 0.36 & 1.20 & 1.43 & 0.22 & -2.05 & -4.36 & P\end{array}$

$\begin{array}{lllllll}0.36 & 1.20 & 1.43 & 0.22 & -2.05 & -4.36 & P \\ 0.34 & 1.13 & 1.36 & 0.27 & -1.78 & -3.86 & P\end{array}$

A: Absolute difference from base level

$\mathrm{P}$ : Percentage difference from base level

* $(+)$ reflects a depreciation of the US\$

** $(+)$ reflects an appreciation 


\section{Table 3.12e}

Worldwide fall in share prices by $25 \%$ over 8 quarters accompanied by an increase in the external financing cost rate for firms by 1 percentage point and a reduction in consumer confidence

Cumulated effects in percentages, unless stated otherwise

Euro Area

Effects

Real gross domestic product (GDP)

Private consumption

Business investment

Housing investment

Exports

Imports

Output gap

Business employment

Unemployment (\% of labour force)

Labour productivity per person

Compensation per employee

Unit labour cost

Private consumption deflator

Export deflator

Import deflator

GDP deflator

Inflation (private consumption deflator)

Cash flow

Personal disposable income

Trade balance (\% GDP)

Government debt (\% GDP)

Government financial balance (\% GDP)

Short-term interest rate (percentage points)

Long-term interest rate (percentage points)

Exchange rate (euro per US\$)*

Share price index

House price index

M3

Bank loans

Net wealth private sector

Effective exchange rate **

World trade volume

Weighted export price

Weighted import price

\begin{tabular}{|c|c|c|c|c|c|}
\hline Year 1 & Year 2 & Year 3 & $\underline{\text { Year } 4}$ & Year 5 & Year 6 \\
\hline-1.04 & -1.69 & -1.97 & -1.79 & -1.49 & -1.14 \\
\hline-1.46 & -1.65 & -1.72 & -1.73 & -1.51 & -1.17 \\
\hline-2.78 & -7.27 & -8.14 & -5.37 & -3.03 & -1.33 \\
\hline 0.12 & 0.53 & 0.93 & 1.04 & 1.01 & 1.07 \\
\hline-0.15 & -1.15 & -2.50 & -3.41 & -3.73 & -3.70 \\
\hline-0.47 & -2.03 & -3.30 & -3.70 & -3.53 & -3.14 \\
\hline-1.07 & -1.62 & -1.58 & -1.08 & -0.59 & -0.17 \\
\hline-0.23 & -0.67 & -1.02 & -1.08 & -0.88 & -0.55 \\
\hline 0.17 & 0.51 & 0.77 & 0.81 & 0.66 & 0.41 \\
\hline-0.91 & -1.13 & -1.02 & -0.73 & -0.56 & -0.48 \\
\hline-0.27 & -1.07 & -2.00 & -3.07 & -4.32 & -5.64 \\
\hline 0.65 & 0.07 & -0.97 & -2.34 & -3.78 & -5.20 \\
\hline-0.06 & -0.33 & -0.74 & -1.65 & -2.93 & -4.41 \\
\hline 0.00 & -0.08 & -0.27 & -0.76 & -1.74 & -3.07 \\
\hline-0.06 & -0.16 & -0.29 & -0.33 & -0.45 & -0.84 \\
\hline-0.05 & -0.29 & -0.65 & -1.43 & -2.62 & -4.05 \\
\hline-0.06 & -0.27 & -0.41 & -0.92 & -1.31 & -1.54 \\
\hline-1.71 & -2.44 & -2.44 & -2.33 & -2.82 & -3.79 \\
\hline-0.75 & -2.08 & -3.13 & -4.03 & -4.89 & -5.87 \\
\hline 0.13 & 0.17 & 0.01 & -0.39 & -0.88 & -1.37 \\
\hline 0.90 & 1.59 & 1.99 & 2.12 & 2.13 & 2.12 \\
\hline-0.11 & -0.03 & 0.07 & 0.34 & 0.67 & 0.86 \\
\hline-0.90 & -1.62 & -1.80 & -2.19 & -2.40 & -2.44 \\
\hline-0.76 & -1.46 & -1.71 & -2.10 & -2.33 & -2.41 \\
\hline-0.30 & -0.91 & -0.95 & -0.34 & 0.26 & 0.44 \\
\hline-25.00 & -25.00 & -20.34 & -7.81 & 0.00 & 0.00 \\
\hline 0.17 & 0.70 & 1.43 & 1.65 & 1.14 & -0.29 \\
\hline-0.11 & -0.21 & -0.11 & 0.16 & 0.23 & -0.34 \\
\hline-0.22 & 0.12 & 2.10 & 6.30 & 12.59 & 20.68 \\
\hline 0.16 & 0.48 & 0.56 & 0.01 & -1.49 & -3.89 \\
\hline 0.02 & 0.33 & 0.34 & -0.41 & -1.29 & -1.88 \\
\hline-0.69 & -2.41 & -3.72 & -4.05 & -3.78 & -3.35 \\
\hline 0.12 & 0.04 & -0.30 & -1.04 & -2.43 & -4.12 \\
\hline 0.10 & 0.00 & -0.32 & -0.99 & -2.26 & -3.85 \\
\hline
\end{tabular}

\footnotetext{
A: Absolute difference from base level

$P$ : Percentage difference from base leve

* $(+)$ reflects a depreciation of the euro

** $(+)$ reflects an appreciation
} 
Table 3.12f

Worldwide fall in share prices by $25 \%$ over 8 quarters accompanied by an increase in the external financing cost rate for firms by 1 percentage point and a reduction in consumer confidence

Cumulated effects in percentages, unless stated otherwise

United States

Effects

Real gross domestic product (GDP)

Private consumption

Business investment

Housing investment

Exports

Imports

Output gap

Business employment

Unemployment (\% of labour force)

Labour productivity per person

Compensation per employee

Unit labour cost

Private consumption deflator

Export deflator

Import deflator

GDP deflator

Inflation (private consumption deflator)

Cash flow

Personal disposable income

Trade balance (\% GDP)

Government debt (\% GDP)

Government financial balance (\% GDP)

Short-term interest rate (percentage points)

Long-term interest rate (percentage points)

Exchange rate (US\$ per euro)*

Share price index

House price index

M3

Bank loans

Net wealth private sector

Effective exchange rate **

World trade volume

Weighted export price

Weighted import price

\begin{tabular}{|c|c|c|c|c|c|}
\hline Year 1 & Year 2 & Year 3 & Year 4 & Year 5 & Year 6 \\
\hline-1.43 & -2.79 & -3.24 & -3.12 & -2.55 & -2.10 \\
\hline-1.64 & -2.89 & -3.32 & -3.53 & -3.13 & -2.71 \\
\hline-3.30 & -8.12 & -9.97 & -8.35 & -5.42 & -2.90 \\
\hline 0.20 & 0.77 & 1.22 & 1.10 & 0.46 & -0.40 \\
\hline-0.05 & -0.58 & -1.43 & -2.46 & -3.61 & -4.81 \\
\hline-1.57 & -4.16 & -5.72 & -6.15 & -5.45 & -4.45 \\
\hline-1.49 & -2.75 & -2.85 & -2.35 & -1.51 & -0.97 \\
\hline-0.81 & -1.82 & -2.26 & -2.23 & -1.80 & -1.36 \\
\hline 0.66 & 1.48 & 1.84 & 1.82 & 1.47 & 1.11 \\
\hline-0.72 & -1.16 & -1.16 & -1.03 & -0.82 & -0.78 \\
\hline-0.32 & -1.23 & -2.29 & -3.23 & -4.02 & -4.79 \\
\hline 0.41 & -0.07 & -1.15 & -2.22 & -3.22 & -4.04 \\
\hline-0.07 & -0.45 & -0.97 & -1.62 & -2.40 & -3.28 \\
\hline 0.06 & 0.05 & -0.26 & -0.95 & -2.14 & -3.68 \\
\hline 0.05 & 0.23 & 0.46 & 0.46 & 0.00 & -0.95 \\
\hline-0.04 & -0.35 & -0.84 & -1.45 & -2.20 & -3.06 \\
\hline-0.07 & -0.39 & -0.52 & -0.65 & -0.80 & -0.90 \\
\hline-2.13 & -3.66 & -3.86 & -3.66 & -3.40 & -3.78 \\
\hline-0.75 & -2.26 & -3.57 & -4.62 & -5.45 & -6.37 \\
\hline 0.22 & 0.54 & 0.65 & 0.57 & 0.32 & 0.05 \\
\hline 1.24 & 2.85 & 3.89 & 4.32 & 4.13 & 3.92 \\
\hline-0.35 & -0.56 & -0.37 & -0.02 & 0.40 & 0.58 \\
\hline-1.20 & -2.55 & -2.79 & -2.58 & -2.13 & -1.85 \\
\hline-1.02 & -2.27 & -2.65 & -2.55 & -2.19 & -1.92 \\
\hline 0.30 & 0.92 & 0.95 & 0.34 & -0.26 & -0.43 \\
\hline-25.00 & -25.00 & -20.34 & -7.81 & 0.00 & 0.00 \\
\hline 0.59 & 1.01 & 0.33 & -1.16 & -3.04 & -4.84 \\
\hline-0.16 & -0.80 & -1.78 & -2.95 & -4.13 & -5.35 \\
\hline-0.48 & -0.42 & 4.60 & 18.56 & 36.80 & 53.84 \\
\hline 1.03 & 3.95 & 7.38 & 9.98 & 10.80 & 9.98 \\
\hline-0.74 & -1.67 & -1.95 & -2.04 & -2.25 & -2.83 \\
\hline-0.50 & -2.03 & -3.67 & -4.72 & -5.27 & -5.56 \\
\hline 0.74 & 1.58 & 1.08 & -0.99 & -3.94 & -6.52 \\
\hline 0.66 & 1.42 & 0.98 & -0.88 & -3.54 & -5.90 \\
\hline
\end{tabular}

A: Absolute difference from base level

$P$ : Percentage difference from base level

* $(+)$ reflects a depreciation of the US\$

** $(+)$ reflects an appreciation 
Table 3.13a

Autonomous increase in the wage level in the euro area by $1 \%$ over 4 quarters Cumulated effects in percentages, unless stated otherwise

\begin{tabular}{|c|c|c|c|c|c|c|}
\hline Effects & $\underline{\text { Year } 1}$ & Year 2 & $\underline{\text { Year } 3}$ & Year 4 & $\underline{\text { Year } 5}$ & $\underline{\text { Year } 6}$ \\
\hline Real gross domestic product (GDP) & 0.01 & -0.17 & -0.22 & -0.20 & -0.12 & -0.02 \\
\hline Private consumption & 0.04 & -0.13 & -0.24 & -0.20 & -0.11 & 0.02 \\
\hline Business investment & -0.01 & -0.37 & -0.59 & -0.47 & -0.25 & 0.00 \\
\hline Housing investment & 0.02 & -0.02 & -0.06 & -0.07 & -0.05 & -0.02 \\
\hline Exports & -0.03 & -0.11 & -0.11 & -0.14 & -0.14 & -0.11 \\
\hline Imports & 0.00 & -0.02 & -0.13 & -0.15 & -0.10 & -0.02 \\
\hline Output gap & -0.08 & -0.24 & -0.25 & -0.18 & -0.08 & 0.04 \\
\hline Business employment & -0.15 & -0.24 & -0.31 & -0.32 & -0.26 & -0.15 \\
\hline Unemployment (\% of labour force) & 0.11 & 0.18 & 0.23 & 0.24 & 0.20 & 0.11 \\
\hline Labour productivity per person & 0.08 & 0.00 & 0.04 & 0.10 & 0.14 & 0.14 \\
\hline Compensation per employee & 1.00 & 1.27 & 1.35 & 1.28 & 1.07 & 0.79 \\
\hline Unit labour cost & 0.92 & 1.27 & 1.31 & 1.18 & 0.94 & 0.66 \\
\hline Private consumption deflator & 0.41 & 0.96 & 1.20 & 1.22 & 1.05 & 0.75 \\
\hline Export deflator & 0.07 & 0.33 & 0.55 & 0.74 & 0.79 & 0.71 \\
\hline Import deflator & -0.07 & -0.16 & 0.05 & 0.28 & 0.48 & 0.62 \\
\hline GDP deflator & 0.29 & 0.83 & 1.14 & 1.21 & 1.09 & 0.83 \\
\hline Inflation (private consumption deflator) & 0.41 & 0.54 & 0.24 & 0.02 & -0.17 & -0.29 \\
\hline Cash flow & -0.45 & 0.13 & 0.66 & 1.01 & 1.12 & 1.02 \\
\hline Personal disposable income & 0.81 & 0.91 & 0.94 & 0.89 & 0.76 & 0.59 \\
\hline Trade balance (\% GDP) & 0.04 & 0.12 & 0.18 & 0.17 & 0.12 & 0.04 \\
\hline Government debt (\% GDP) & -0.16 & -0.16 & -0.13 & -0.11 & -0.10 & -0.14 \\
\hline Government financial balance (\% GDP) & -0.05 & -0.26 & -0.20 & -0.10 & 0.02 & 0.15 \\
\hline Short-term interest rate (percentage points) & 0.56 & 0.63 & 0.17 & -0.11 & -0.31 & -0.41 \\
\hline Long-term interest rate (percentage points) & 0.47 & 0.60 & 0.22 & -0.05 & -0.26 & -0.37 \\
\hline Exchange rate (euro per US $\$)^{*}$ & -0.52 & -0.47 & 0.15 & 0.56 & 0.86 & 0.98 \\
\hline Share price index & -3.74 & -6.80 & -4.09 & -0.24 & 3.43 & 5.89 \\
\hline House price index & 0.39 & 0.69 & 0.93 & 1.18 & 1.30 & 1.25 \\
\hline M3 & 0.21 & -0.03 & 0.26 & 0.63 & 0.97 & 1.19 \\
\hline Bank loans & 0.03 & -0.36 & -1.01 & -1.40 & -1.35 & -0.91 \\
\hline Net wealth private sector & 0.03 & 0.41 & 0.92 & 1.33 & 1.54 & 1.51 \\
\hline Effective exchange rate ** & 0.40 & 0.34 & -0.13 & -0.43 & -0.62 & -0.69 \\
\hline World trade volume & 0.00 & -0.02 & -0.11 & -0.14 & -0.13 & -0.08 \\
\hline Weighted export price & -0.20 & -0.04 & 0.37 & 0.64 & 0.81 & 0.83 \\
\hline Weighted import price & -0.19 & -0.02 & 0.37 & 0.64 & 0.81 & 0.83 \\
\hline
\end{tabular}

A: Absolute difference from base level

$\mathrm{P}$ : Percentage difference from base level

* (+) reflects a depreciation of the euro

** $(+)$ reflects an appreciation 


\section{Table 3.13b}

Autonomous increase in the wage level in Germany by $1 \%$ over 4 quarters Cumulated effects in percentages, unless stated otherwise

\section{Euro Area}

Effects

Private consumption

Business investment

Housing investment

Exports

Imports

Output gap

Business employment

Unemployment (\% of labour force)

Labour productivity per person

Compensation per employee

Unit labour cost

Private consumption deflator

Export deflator

Import deflator

GDP deflator

Inflation (private consumption deflator)

Cash flow

Personal disposable income

Trade balance (\% GDP)

Government debt (\% GDP)

Government financial balance (\% GDP)

Short-term interest rate (percentage points)

Long-term interest rate (percentage points)

Exchange rate (euro per US\$)*

Share price index

House price index

M3

Bank loans

Net wealth private sector

Effective exchange rate **

World trade volume

Weighted export price

Weighted import price
Real gross domestic product (GDP)

$\begin{array}{rrrrrrr}\text { Year 1 } & \text { Year 2 } & \text { Year 3 } & \text { Year 4 } & \text { Year 5 } & \text { Year 6 } & \\ 0.02 & -0.01 & -0.04 & -0.04 & -0.03 & -0.02 & \text { P } \\ 0.05 & 0.03 & 0.00 & 0.00 & 0.01 & 0.02 & \mathrm{P} \\ 0.02 & -0.10 & -0.22 & -0.24 & -0.21 & -0.16 & \mathrm{P} \\ 0.02 & 0.04 & 0.04 & 0.03 & 0.03 & 0.04 & \mathrm{P} \\ 0.00 & -0.03 & -0.03 & -0.05 & -0.06 & -0.06 & \mathrm{P} \\ 0.01 & 0.01 & -0.01 & -0.03 & -0.04 & -0.03 & \mathrm{P} \\ & & & & & & \\ 0.00 & -0.03 & -0.05 & -0.04 & -0.01 & 0.01 & \mathrm{~A} \\ -0.04 & -0.06 & -0.06 & -0.06 & -0.05 & -0.02 & \mathrm{P} \\ 0.03 & 0.04 & 0.05 & 0.05 & 0.03 & 0.02 & \mathrm{~A} \\ 0.05 & 0.03 & 0.02 & 0.02 & 0.02 & 0.01 & \mathrm{P} \\ & & & & & & \\ 0.35 & 0.43 & 0.46 & 0.46 & 0.44 & 0.40 & \mathrm{P} \\ 0.30 & 0.40 & 0.45 & 0.45 & 0.43 & 0.39 & \mathrm{P} \\ 0.08 & 0.23 & 0.33 & 0.36 & 0.35 & 0.32 & \mathrm{P} \\ 0.00 & 0.00 & 0.05 & 0.11 & 0.16 & 0.20 & \mathrm{P} \\ -0.01 & -0.05 & -0.03 & 0.02 & 0.08 & 0.12 & \mathrm{P} \\ 0.05 & 0.19 & 0.29 & 0.34 & 0.34 & 0.32 & \mathrm{P} \\ 0.08 & 0.15 & 0.10 & 0.03 & -0.01 & -0.03 & \mathrm{~A} \\ & & & & & & \\ -0.19 & -0.04 & 0.11 & 0.22 & 0.26 & 0.27 & \mathrm{P} \\ 0.26 & 0.33 & 0.34 & 0.33 & 0.30 & 0.27 & \mathrm{P} \\ & & & & & & \\ 0.00 & 0.00 & 0.01 & 0.02 & 0.02 & 0.02 & \mathrm{~A} \\ -0.06 & -0.06 & -0.05 & -0.04 & -0.03 & -0.04 & \mathrm{~A} \\ 0.01 & -0.07 & -0.07 & -0.05 & -0.01 & 0.02 & \mathrm{~A} \\ & & & & & & \\ 0.11 & 0.20 & 0.11 & 0.03 & -0.03 & -0.04 & \mathrm{~A} \\ 0.09 & 0.19 & 0.11 & 0.04 & -0.01 & -0.03 & \mathrm{~A} \\ -0.11 & -0.17 & -0.03 & 0.09 & 0.18 & 0.21 & \mathrm{P} \\ -0.83 & -2.14 & -1.85 & -0.87 & 0.01 & 0.51 & \mathrm{P} \\ 0.05 & 0.09 & 0.13 & 0.14 & 0.12 & 0.07 & \mathrm{P} \\ 0.08 & -0.02 & 0.01 & 0.09 & 0.18 & 0.24 & \mathrm{P} \\ 0.00 & -0.15 & -0.41 & -0.61 & -0.68 & -0.63 & \mathrm{P} \\ -0.02 & 0.04 & 0.14 & 0.23 & 0.28 & 0.30 & \mathrm{P} \\ 0.08 & 0.13 & 0.02 & -0.07 & -0.13 & -0.15 & \mathrm{P} \\ 0.00 & 0.00 & -0.02 & -0.05 & -0.05 & -0.05 & \mathrm{P} \\ -0.05 & -0.07 & 0.02 & 0.11 & 0.18 & 0.23 & \mathrm{P} \\ -0.05 & -0.07 & 0.02 & 0.11 & 0.18 & 0.22 & \mathrm{P} \\ & & & & & & \end{array}$

A: Absolute difference from base level

$P$ : Percentage difference from base level

* $(+)$ reflects a depreciation of the euro

** $(+)$ reflects an appreciation 
Table 3.13c

Autonomous increase in the wage level in Germany by $1 \%$ over 4 quarters Cumulated effects in percentages, unless stated otherwise

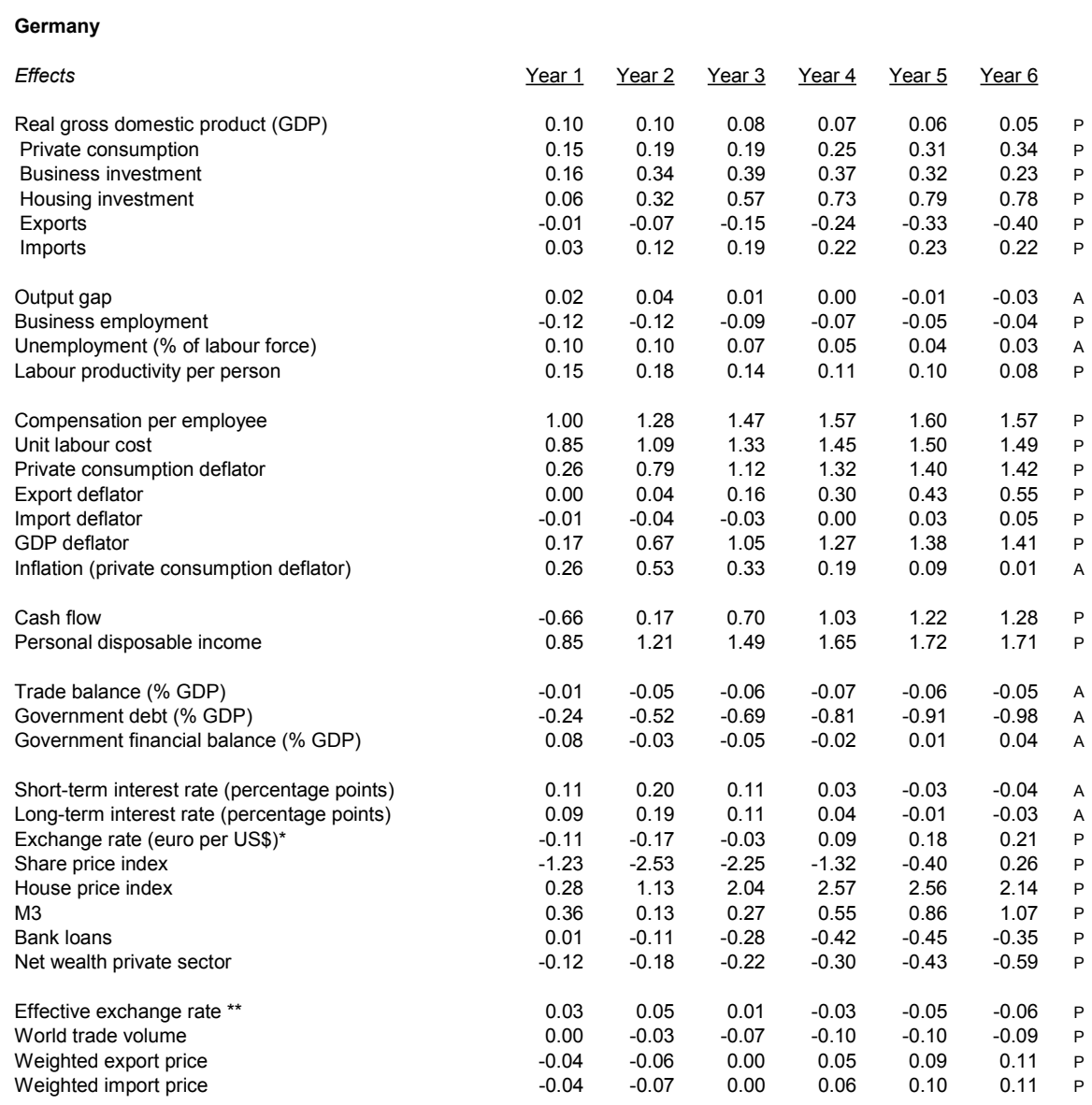

A: Absolute difference from base level

P: Percentage difference from base level

* $(+)$ reflects a depreciation of the euro

** $(+)$ reflects an appreciation 
Table 3.14

Permanent reduction in the supply of labour in the euro area by $1 \%$

Cumulated effects in percentages, unless stated otherwise

\section{Euro Area}

Effects

Real gross domestic product (GDP)

Private consumption

Business investment

Housing investment

Exports

Imports

Output gap

Business employment

Unemployment (\% of labour force)

Labour productivity per person

Compensation per employee

Unit labour cost

Private consumption deflator

Export deflator

Import deflator

GDP deflator

Inflation (private consumption deflator)

Cash flow

Personal disposable income

Trade balance (\% GDP)

Government debt (\% GDP)

Government financial balance (\% GDP)

Short-term interest rate (percentage points)

Exchange rate (euro per US\$)*

Share price index

M3

Bank loans

Net wealth private sector

Effective exchange rate **

World trade volume

Weighted export price

Weighted import price
Long-term interest rate (percentage points)

House price index

$\begin{array}{rrrrrrr}\text { Year 1 } & \text { Year 2 } & \text { Year 3 } & \text { Year 4 } & \text { Year 5 } & \text { Year 6 } & \\ -0.07 & -0.26 & -0.52 & -0.84 & -1.11 & -1.29 & \mathrm{P} \\ 0.01 & -0.13 & -0.42 & -0.84 & -1.22 & -1.47 & \mathrm{P} \\ -0.20 & -0.64 & -1.19 & -1.81 & -2.30 & -2.52 & \mathrm{P} \\ -0.11 & -0.42 & -0.79 & -1.20 & -1.63 & -2.02 & \mathrm{P} \\ -0.02 & 0.01 & -0.07 & -0.23 & -0.46 & -0.70 & \mathrm{P} \\ 0.09 & 0.22 & 0.11 & -0.18 & -0.58 & -0.91 & \mathrm{P} \\ & & & & & & \\ 0.45 & 0.21 & -0.08 & -0.39 & -0.60 & -0.70 & \mathrm{~A} \\ -0.05 & -0.25 & -0.55 & -0.91 & -1.24 & -1.47 & \mathrm{P} \\ -0.88 & -0.72 & -0.49 & -0.22 & 0.03 & 0.21 & \mathrm{~A} \\ -0.05 & -0.11 & -0.13 & -0.14 & -0.11 & -0.05 & \mathrm{P} \\ & & & & & & \\ 0.19 & 0.90 & 1.86 & 2.84 & 3.67 & 4.25 & \mathrm{P} \\ 0.23 & 0.99 & 1.99 & 2.99 & 3.82 & 4.34 & \mathrm{P} \\ 0.05 & 0.50 & 1.42 & 2.56 & 3.63 & 4.44 & \mathrm{P} \\ -0.02 & 0.07 & 0.52 & 1.24 & 2.02 & 2.69 & \mathrm{P} \\ -0.07 & -0.17 & -0.27 & -0.17 & 0.18 & 0.72 & \mathrm{P} \\ 0.03 & 0.36 & 1.16 & 2.23 & 3.28 & 4.13 & \mathrm{P} \\ 0.05 & 0.45 & 0.92 & 1.11 & 1.04 & 0.78 & \mathrm{~A} \\ & & & & & & \\ -0.29 & -0.69 & -0.46 & 0.26 & 1.22 & 2.19 & \mathrm{P} \\ -0.33 & 0.21 & 0.90 & 1.47 & 1.94 & 2.24 & \mathrm{P} \\ & & & & & & \\ -0.02 & 0.02 & 0.21 & 0.47 & 0.67 & 0.77 & \mathrm{~A} \\ -0.06 & -0.05 & -0.03 & 0.06 & 0.19 & 0.29 & \mathrm{~A} \\ 0.08 & -0.11 & -0.41 & -0.61 & -0.67 & -0.57 & \mathrm{~A} \\ & & & & & & \\ 0.41 & 0.82 & 1.31 & 1.38 & 1.11 & 0.65 & \mathrm{~A} \\ 0.35 & 0.73 & 1.21 & 1.33 & 1.13 & 0.72 & \mathrm{~A} \\ -0.41 & -0.76 & -1.08 & -0.85 & -0.16 & 0.78 & \mathrm{P} \\ -2.85 & -6.89 & -13.07 & -15.02 & -13.58 & -9.40 & \mathrm{P} \\ -0.20 & -0.28 & 0.07 & 0.78 & 1.86 & 3.19 & \mathrm{P} \\ -0.35 & -0.53 & -0.75 & -0.69 & -0.22 & 0.57 & \mathrm{P} \\ -0.07 & -0.47 & -1.27 & -2.68 & -4.34 & -5.79 & \mathrm{P} \\ -0.08 & -0.08 & 0.47 & 1.64 & 3.27 & 5.03 & \mathrm{P} \\ & & & & & & \\ 0.31 & 0.57 & 0.80 & 0.60 & 0.08 & -0.58 & \mathrm{P} \\ 0.06 & 0.15 & 0.08 & -0.13 & -0.44 & -0.73 & \mathrm{P} \\ -0.19 & -0.30 & -0.22 & 0.25 & 0.98 & 1.76 & \mathrm{P} \\ -0.18 & -0.28 & -0.19 & 0.28 & 0.99 & 1.76 & \mathrm{P} \\ & & & & & & \end{array}$

A: Absolute difference from base level

P: Percentage difference from base level

* $(+)$ reflects a depreciation of the euro

** $(+)$ reflects an appreciation 


\section{Epilogue}

The current version of EUROMON as described in this Occasional Study is subject to a number of shortcomings. State of the art economic modelling has developed rapidly over the last decade and resulted in the design of theory coherent macro models for forecasting and simulation analysis that explicitly allow for optimising agents, and are therefore less prone to the Lucas critique than the more traditional models. The rise of estimated dynamic stochastic general equilibrium models à la Smets and Wouters (2003) or policy models that combine a theoryconsistent core model with a non-core structure to allow for ad hoc dynamics and data coherence, such as the Bank of England's BEQM model (Harrison et al., 2005), are clear examples of recent progress in macro modelling. For larger multi-country models such as EUROMON, these new approaches have not yet been put into practice. Nonetheless, a further development of the model along these lines would enhance its clarity and, moreover, a strengthening of the theory coherence of the model is imperative for running the model in a forward looking mode.

More in detail, a number of interesting extensions of the current model come to the fore. A first extension is the explicit incorporation of the equilibrium unemployment rate, rather than the exogenous NAWRU, in the supply block of the model. Second, an important drawback of the current model version is that it does not treat international trade as a closed system. This could lead to important "leakages". Third, import prices and competitors' export prices are modelled very rudimentary. Further work on the exchange rate pass through and pricing to market could be considered here.

That said, the current version of the model has a couple of distinct features that are worthwhile maintaining. One important feature is the endogeneity of the equilibrium unemployment rate mentioned earlier as the outcome of optimal firm behaviour (factor demand and price setting) and a 'right-to-manage' wage bargaining framework à la Nickell and Andrews (1983). See Broer, Draper and Huizinga (2000) for an empirical application to the Netherlands. In principle this is very helpful in exploring the effects on wage and price formation of fiscal policy and structural reforms in labour and product markets. This feature is not very common in other macroeconomic policy models, which mainly rely on Calvo pricing and Phillips curve models of inflation. The other feature relates to the endogeneity of house and equity prices in the model and the modelling of private sector net wealth measured at market value as a channel of monetary policy transmission. These features remain crucial in the current policy debate and are therefore important to explore further. 


\section{References}

Bolt, Wilko, and Peter van Els, 2000, Output Gap and Inflation in the EU, DNB Staff Reports, No. 44, Amsterdam: De Nederlandsche Bank.

Bondt de, Gabe, Peter van Els and Ad Stokman, 1997, EUROMON: a macroeconometric multi-country model for the EU, DNB Staff Reports, No. 17, Amsterdam: De Nederlandsche Bank.

Broer, D.P., D.A.G. Draper and F.H. Huizinga, 2000, The equilibrium rate of unemployment in the Netherlands, De Economist 148, No. 3, pp. 345-371.

Coenen, Günter and Juan-Luis Vega, 1999, The determinants for M3 in the euro area, $E C B$ Working Paper, No. 6, Frankfurt am Main: European Central Bank.

Demertzis, Maria, Peter van Els, and Marga Peeters, 2002, EUROMON: The Nederlandsche Bank's Multi-Country Model, WO Research Memorandum, No. 718, Amsterdam: De Nederlandsche Bank.

Deutsche Bundesbank, 2000, Macro-Econometric Multi-Country Model: MEMMOD, Frankfurt am Main: Deutsche Bundesbank.

Elmeskov, J., 1993, High and persistent unemployment: assessment of the problem and its causes, OECD Economics Department Working Papers, 132, Paris.

Els, Peter van, Alberto Locarno, Julian Morgan and Jean-Pierre Villetelle, 2003a, The effects of monetary policy in the Euro Area: evidence from structural macroeconomic models, in Angeloni, Kashyap en Mojon (eds.), Monetary Policy Transmission in the Euro Area, Cambridge University Press, pp. 91-106.

Els, Peter van, Alberto Locarno, Benoît Mojon and Julian Morgan, 2003b, New Macroeconomic Evidence on Monetary Policy Transmission in the Euro Area, The Journal of the European Economic Association, Vol. 1 (2-3), pp. 720-730.

Fagan, Gabriël, Jerôme Henry and Ricardo Mestre, 2005, An area-wide model of the euro area, Economic Modelling, vol. 22 (1), pp. 39-59.

Fagan, Gabriël, and Julian Morgan (eds), 2005, Econometric Models of the Euro-area Central Banks, Cheltenham: Edward Elgar (forthcoming)

Fair, Ray, 1984, Specification, estimation and analysis of macroeconometric models, Cambridge MA/London: Harvard University Press.

Fase, Martin M.G., 1998, On Money and Credit in Europe, Cheltenham, UK: Edward Elgar. Harrison, Richard, Kalin Nikolov, Meghan Quinn, Gareth Ramsay, Alasdair Scott and Ryland Thomas, 2005, The Bank of England Quarterly Model, London: Bank of England.

Jeanfils, Philippe, 2000, A model with explicit expectations for Belgium, BNB Working Paper Research Series, No. 4, March, Brussels: National Bank of Belgium.

Laxton, Douglas, Peter Isard, Hamid Faruqee, Eswar Prasad and Bart Turtelboom, 1998, MUTIMOD Mark III: The Core Dynamic and Steady-State Models, Occassional Paper 164, Washington DC: International Monetary Fund.

Layard, Richard, Stephen Nickell and Richard Jackman, 1992, Unemployment: Macroeconomic Performance and the Labour Market, Oxford: Oxford University Press.

McAdam, P., and J. Morgan, 2003, Analysing monetary policy transmission at the euro area level using structural macroeconomic models, in Angeloni, Kashyap en Mojon (eds.), Monetary Policy Transmission in the Euro Area, Cambridge University Press, pp. 75-90.

Nederlandsche Bank, De, 2000, EUROMON: The Nederlandsche Bank's Multi-Country Model for Policy Analysis in Europe, Monetaire Monografieën, 19, Amsterdam: De Nederlandsche Bank

Nickell, S.J. and M. Andrews, 1983, Unions, Real Wages and Employment in Britain 1951-79, Oxford Economic Papers, 35, pp. 183-206. 
NIESR, 2005, NiGEM model description, London, National Institute for Economic and Social Research.

Peeters, H.M.M., and A.H.J. den Reijer, 2002, On Wage formation, wage development and unemployment flexibility: a comparison between European countries and the United States, $W O$ Research Memorandum, No. 712, Amsterdam: De Nederlandsche Bank.

Smets, Frank, and Raf Wouters, 2003, An estimated dynamic stochastic general equilibrium model of the euro area, The Journal of the European Economic Association, vol. 1 (5), pp. 11231175 .

Torres, R. and J.P. Martin, 1990, Measuring potential output in the seven major OECD countries, OECD Economic Studies, 14, Paris. 


\section{ANNEX}

Behavioural equations and a stylized presentation of EUROMON 


\section{Contents}

$\begin{array}{llr}\text { A } & \text { Behavioural equations } & 99\end{array}$

$\begin{array}{llr}\text { A.1 Introduction and notation } & 99\end{array}$

A.2 Labour market and physical capital stock: potential output in businesses 101

A.3 Labour market and physical capital stock:

non-residential business investment 102

$\begin{array}{lll}\text { A.4 Labour market and physical capital stock: business employment } & 104\end{array}$

$\begin{array}{lll}\text { A.5 Private consumption } & 106\end{array}$

$\begin{array}{lll}\text { A.6 Housing investment } & 109\end{array}$

$\begin{array}{lll}\text { A.7 National income: total final expenditures } & 110\end{array}$

$\begin{array}{lll}\text { A.8 Foreign trade: exports } & 111\end{array}$

$\begin{array}{lll}\text { A.9 Foreign trade: imports } & 112\end{array}$

$\begin{array}{ll}\text { A.10 Foreign trade: net exports primary income } & 115\end{array}$

$\begin{array}{ll}\text { A.11 Wages and prices: non-government wage rate } & 116\end{array}$

$\begin{array}{ll}\text { A.12 Wages and prices: price deflator private consumption } & 118\end{array}$

$\begin{array}{ll}\text { A.13 Wages and prices: price deflator exports of goods and services } & 121\end{array}$

$\begin{array}{ll}\text { A.14 Wages and prices: price deflator imports of goods and services } & 122\end{array}$

$\begin{array}{ll}\text { A.15 Public sector: transfers from public sector to private sector } & 124\end{array}$

A.16 Monetary and financial sector: nominal long-term interest rate 126

$\begin{array}{ll}\text { A.17 Monetary and financial sector: broad money } & 128\end{array}$

$\begin{array}{ll}\text { A.18 Monetary and financial sector: bank credit to the private sector } & 130\end{array}$

$\begin{array}{ll}\text { A.19 Monetary and financial sector: equity prices } & 133\end{array}$

$\begin{array}{lll}\text { A.20 Monetary and financial sector: housing prices } & 134\end{array}$

$\begin{array}{lll}\text { B A stylised presentation of EUROMON } & 137\end{array}$ 


\section{A Behavioural equations}

\section{A.1 Introduction and notation}

In the following sections we present EUROMON's estimated and/or calibrated behavioural equations. Each section reports the general econometric specification of one equation, along with a table containing in columns the parameter estimates, $t$-values and the adjusted $\bar{R}^{2}$ for each country. Calibrated parameters do not report $t$-values. For the sake of brevity we do not report the intercepts and dummies that capture structural breaks and residual seasonality.

Other important information on notation:

- Subscript $t$ denotes time.

- $\Delta$ is the first difference operator, i.e. $\Delta v a r_{t}=v a r_{t}-v a r_{t-1}$.

- log denotes natural logarithms.

- Dotted variables are growth rates, i.e. $v a \dot{r} r_{t} \equiv 100 \Delta_{4} \log v a r_{t} \equiv 100\left(\log v a r_{t}-\log v a r_{t-4}\right)$.

- Upper-case variables are values in nominal terms.

- Lower-case variables are volumes (including numbers of persons) or prices (including wages, nominal exchange rates, and nominal interest rates).

- Underlined variables are exogenous. Underlined variables with a subscript $t$ are timevarying; those without are not.

- Nominal variables are expressed in the currency of the own country.

- Euro-area-wide variables are aggregated or weighted with 1990 GDP weights for the

EMU-countries included in EUROMON.

- Variables with superscript $w$ are weighted variables. Weights are calculated using GDP-weights and 1990 exchange rates.

- Variables with superscript mres denote measurement errors.

- The following holds in the behavioural equations:

- Greek symbols represent estimated or calibrated parameters.

- Dummy variables included to capture structural breaks and residual seasonality are not reported in the equations and tables.

- Intercepts are not reported in the equations and tables.

- In the tables LT $(\alpha)$ refers to the adjustment parameter of the Error-Correction term.

- $\quad t$-values are reported in brackets and relate to Newey-West heteroscedasticity- and autocorrelation-consistent standard errors.

- Parameter estimates without a $t$-value are calibrated.

- $\quad \bar{R}^{2}$ is the adjusted $R^{2}$. 



\section{A.2 Labour market and physical capital stock: potential output in businesses}

For AU, BE, DE, FI, FR, IT, NL, SW, UK, US potential output in enterprises is based on a CES-production function:

$\log y_{b, t}^{*}=\underline{t f p_{t}}-\frac{1}{\rho} \log \left((1-\delta) k_{b, t-1}^{-\rho}+\delta l h_{b, t}^{-\rho}\right)$

while for DK, ES, JP it is based on a Cobb-Douglas production function,

$\log y_{b, t}^{*}=\underline{t f p} \underline{t}_{t}+(1-\delta) \log k_{b, t-1}+\delta \log l h_{b, t}$

with

$y_{b}^{*}=$ potential business production in real terms, value added at factor costs

$\underline{t f p}=$ HP-trend of the logarithm of total factor productivity

$\overline{k_{b}}=$ business capital stock (excluding dwellings) in real terms

$l h_{b}=$ business employment (in labour hours)

Table 1 Calibrated parameters of the potential production equations

\begin{tabular}{|c|c|c|c|c|c|c|c|c|c|c|c|c|c|}
\hline & $\mathrm{AU}$ & $\mathrm{BE}$ & DE & DK & ES & FI & FR & IT & $\mathrm{NL}$ & SW & UK & JP & US \\
\hline$\delta$ & 0.54 & 0.53 & 0.56 & 0.54 & 0.44 & 0.51 & 0.53 & 0.41 & 0.52 & 0.57 & 0.59 & 0.57 & 0.57 \\
\hline$\rho$ & 1.42 & 0.15 & 2.23 & 0 & 0 & 4.06 & 0.47 & 0.96 & 2.21 & 1.29 & 0.74 & 0 & 0.61 \\
\hline
\end{tabular}




\section{A.3 Labour market and physical capital stock:}

\section{non-residential business investment}

$$
\begin{aligned}
\Delta \log i_{b, t}= & \alpha\left\{\log k_{b, t-2}-\log y_{b, t-1}^{*}-\hat{\sigma} \frac{u c c_{t-1}}{\underline{\mu}_{u c c}}+(1+\hat{\sigma}) \hat{\eta}(t-1)\right\} \\
& +\sum_{i=1}^{4} \gamma_{1, i} \Delta \log i_{b, t-i}+\sum_{i=0}^{3} \gamma_{2, i} \Delta \log \left(c_{t-i}+i_{h, t-i}+g_{i, t-i}+g_{c m, t-i}+x_{t-i}\right) \\
& +\sum_{i=1}^{4} \gamma_{3, i} \Delta g a p_{t-i}+\sum_{i=0}^{3} \gamma_{4, i}\left(\Delta r_{l, t-i}-\Delta \dot{p}_{c, t-i}\right) \\
& +\sum_{i=1}^{4} \gamma_{5, i} \Delta \log \frac{C F_{t-i}-T_{\text {dirb }, t-i}}{p_{y, t-i}}+\xi t
\end{aligned}
$$

with

$i_{b}=$ business investment (excluding dwellings) in real terms

$k_{b}=$ business capital stock (excluding dwellings) in real terms

$y_{b}^{*}=$ potential business production in real terms, value added at factor costs

$u c c=$ user cost of capital in real terms

$\underline{\mu}_{u c c}=$ average user cost of capital

$c=$ private consumption in real terms

$i_{h}=$ housing investment in real terms

$g_{i} \quad=$ government investment in real terms

$g_{c m}=$ non wage government consumption in real terms

$x=$ exports of goods and services in real terms

gap $=$ output gap (in \%)

$r_{l}=$ nominal long-term interest rate (in \%)

$\dot{p}_{c}=$ inflation (in \%)

$C F=$ cash flow

$T_{\text {dirb }}=$ corporate taxes

$p_{y} \quad=$ price deflator gross domestic product (index, 1990=100)

$t=$ deterministic linear trend 
Table 2 Calibrated and estimated parameters business investment equations

\begin{tabular}{|c|c|c|c|c|c|c|c|c|c|c|c|c|c|}
\hline & $\mathrm{AU}$ & $\mathrm{BE}$ & $\mathrm{DE}$ & $\mathrm{DK}$ & ES & FI & $\mathrm{FR}$ & IT & NL & SW & UK & JP & US \\
\hline$L T(\alpha)$ & $\begin{array}{l}-0.15 \\
(2.49)\end{array}$ & $\begin{array}{l}-0.08 \\
(1.99)\end{array}$ & $\begin{array}{l}-0.20 \\
(-)\end{array}$ & $\begin{array}{l}-0.21 \\
(4.73)\end{array}$ & $\stackrel{-0.05}{(-)}$ & $\begin{array}{l}-0.08 \\
(2.01)\end{array}$ & $\begin{array}{l}-0.08 \\
(5.84)\end{array}$ & $\begin{array}{l}-0.11 \\
(3.47)\end{array}$ & $\begin{array}{l}-0.20 \\
(2.89)\end{array}$ & $\begin{array}{l}-0.10 \\
(2.29)\end{array}$ & $\underset{(-)}{-0.07}$ & $\underset{(-)}{-0.06}$ & $\begin{array}{l}-0.04 \\
(3.41)\end{array}$ \\
\hline$\hat{\sigma}$ & $\begin{array}{c}-0.41 \\
(-)\end{array}$ & $\begin{array}{c}-0.87 \\
(-)\end{array}$ & $\begin{array}{c}-0.31 \\
(-)\end{array}$ & $\begin{array}{c}-1.00 \\
(-)\end{array}$ & $\begin{array}{c}-1.00 \\
(-)\end{array}$ & $\begin{array}{c}-0.20 \\
(-)\end{array}$ & $\begin{array}{c}-0.68 \\
(-)\end{array}$ & $\underset{(-)}{-0.51}$ & $\begin{array}{c}-0.31 \\
(-)\end{array}$ & $\begin{array}{c}-0.44 \\
(-)\end{array}$ & $\underset{(-)}{-0.58}$ & $\begin{array}{c}-1.00 \\
(-)\end{array}$ & $\begin{array}{c}-0.62 \\
(-)\end{array}$ \\
\hline$\hat{\eta}$ & $\begin{array}{c}0.008 \\
(-)\end{array}$ & $\underset{(-)}{0.008}$ & $\begin{array}{c}0.006 \\
(-)\end{array}$ & & & $\underset{(-)}{0.009}$ & $\begin{array}{c}0.006 \\
(-)\end{array}$ & $\underset{(-)}{0.008}$ & $\underset{(-)}{0.004}$ & $\begin{array}{c}0.006 \\
(-)\end{array}$ & $\begin{array}{c}0.003 \\
(-)\end{array}$ & & $\underset{(-)}{0.004}$ \\
\hline$\Delta \log i_{b, t-1}$ & $\begin{array}{l}-0.32 \\
(3.75)\end{array}$ & $\begin{array}{l}-0.51 \\
(4.35)\end{array}$ & $\begin{array}{l}-0.30 \\
(2.35)\end{array}$ & & & & & $\begin{array}{l}0.30 \\
(2.64)\end{array}$ & $\begin{array}{l}-0.34 \\
(3.27)\end{array}$ & & & $\begin{array}{l}0.60 \\
(5.53)\end{array}$ & \\
\hline$\Delta \log i_{b, t-2}$ & $\begin{array}{l}-0.25 \\
(3.76)\end{array}$ & & $\begin{array}{l}-0.25 \\
(3.38)\end{array}$ & & & & & & & & & & \\
\hline$\Delta \log i_{b, t-3}$ & & & & & $\begin{array}{l}0.21 \\
(2.43)\end{array}$ & & $\begin{array}{l}0.21 \\
(2.52)\end{array}$ & & $\begin{array}{c}0.18 \\
(1.62)\end{array}$ & & $\begin{array}{l}0.16 \\
(2.57)\end{array}$ & & \\
\hline$\Delta \log i_{b, t-4}$ & $\begin{array}{l}0.40 \\
(3.72)\end{array}$ & & & $\begin{array}{l}0.28 \\
(5.63)\end{array}$ & & $\begin{array}{l}0.24 \\
(2.01)\end{array}$ & & & $\begin{array}{l}0.16 \\
(1.53)\end{array}$ & $\begin{array}{l}0.41 \\
(5.99)\end{array}$ & $\begin{array}{l}0.14 \\
(1.78)\end{array}$ & & $\begin{array}{l}0.25 \\
(2.71)\end{array}$ \\
\hline $\begin{array}{l}\Delta \log \left(c_{t}+i_{h . t}\right. \\
\left.\quad+g_{i, t}+g_{c m . t}+x_{t}\right)\end{array}$ & $\begin{array}{c}0.86 \\
(2.53)\end{array}$ & & $\begin{array}{c}2.84 \\
(5.98)\end{array}$ & & & & $\begin{array}{l}0.97 \\
(6.60)\end{array}$ & & & & & & $\begin{array}{c}1.12 \\
(3.19)\end{array}$ \\
\hline $\begin{array}{l}\Delta \log \left(c_{t-1}+i_{h, t-1}\right. \\
\left.\quad+g_{i . t-1}+g_{c m, t-1}+x_{t-1}\right)\end{array}$ & & & & & & & $\begin{array}{l}0.78 \\
(3.90)\end{array}$ & & & & $\begin{array}{l}0.63 \\
(2.25)\end{array}$ & & \\
\hline $\begin{array}{l}\Delta \log \left(c_{t-2}+i_{h, t-2}\right. \\
\left.\quad+g_{i . t-2}+g_{c m, t-2}+x_{t-2}\right)\end{array}$ & & $\begin{array}{c}0.71 \\
(3.09)\end{array}$ & & & & $\begin{array}{l}1.08 \\
(3.63)\end{array}$ & $\begin{array}{l}0.58 \\
(3.76)\end{array}$ & & & & & $\begin{array}{c}0.95 \\
(3.63)\end{array}$ & \\
\hline $\begin{array}{l}\Delta \log \left(c_{t-3}+i_{h, t-3}\right. \\
\left.\quad+g_{i . t-3}+g_{c m, t-3}+x_{t-3}\right)\end{array}$ & & & & & & $\begin{array}{c}0.69 \\
(2.57)\end{array}$ & & & $\begin{array}{c}1.70 \\
(3.38)\end{array}$ & & & $\begin{array}{c}0.50 \\
(3.40)\end{array}$ & \\
\hline $\begin{array}{l}\frac{1}{2} \sum_{i=0}^{1} \Delta \log \left(c_{t-i}+i_{h, t-i}\right. \\
\left.\quad+g_{i . t-i}+g_{c m, t-i}+x_{t-i}\right)\end{array}$ & & & & & $\begin{array}{c}1.89 \\
(2.41)\end{array}$ & & & & & & & & \\
\hline $\begin{aligned} \frac{1}{2} \sum_{i=1}^{2} & \Delta \log \left(c_{t-i}+i_{h, t-i}\right. \\
& \left.+g_{i . t-i}+g_{c m, t-i}+x_{t-i}\right)\end{aligned}$ & & & & $\begin{array}{c}1.53 \\
(1.67)\end{array}$ & & & & & & & & & \\
\hline $\begin{aligned} \frac{1}{2} \sum_{i=2}^{3} & \Delta \log \left(c_{t-i}+i_{h, t-i}\right. \\
& \left.+g_{i . t-i}+g_{c m, t-i}+x_{t-i}\right)\end{aligned}$ & & & & & & & & & & $\begin{array}{c}1.09 \\
(1.99)\end{array}$ & & & \\
\hline $\begin{array}{l}\frac{1}{4} \sum_{i=1}^{4} \Delta \log \left(c_{t-i}+i_{h, t-i}\right. \\
\left.\quad+g_{i . t-i}+g_{c m, t-i}+x_{t-i}\right)\end{array}$ & & & & & & & & $\begin{array}{c}1.45 \\
(2.41)\end{array}$ & & & & & \\
\hline$\Delta g a p_{t-1}$ & $\begin{array}{l}0.003 \\
(1.97)\end{array}$ & & & & & & & & & & & & $\begin{array}{l}0.010 \\
(3.80)\end{array}$ \\
\hline$\Delta r_{l . t-1}-\Delta \dot{p}_{c . t-1}$ & & & & & & & & $\begin{array}{l}-0.006 \\
(3.10)\end{array}$ & & & & & \\
\hline$\Delta \log \frac{C F_{t-2}-T_{\text {dirb.t-2 }}}{p_{y, t-2}}$ & & & & $\begin{array}{c}0.25 \\
(2.27)\end{array}$ & & & & & & & & & \\
\hline$\Delta \log \frac{C F_{t-3}-T_{\text {dirb.t-3 }}}{p_{y, t-3}}$ & & & & & & & & & & $\begin{array}{c}0.21 \\
(3.34)\end{array}$ & & & \\
\hline$\Delta \log \frac{C F_{t-4}-T_{\text {dirb.t-4 }}}{p_{y, t-4}}$ & & $\begin{array}{c}0.47 \\
(2.56)\end{array}$ & & & & & $\begin{array}{c}0.26 \\
(3.44)\end{array}$ & & & & & & \\
\hline$\frac{1}{4} \sum_{i=4}^{7} \Delta \log \frac{C F_{t-i}-T_{d i r b, t-i}}{p_{y . t}-i}$ & & & & & $\begin{array}{c}0.91 \\
(3.09)\end{array}$ & & & & & & & & \\
\hline$t$ & $\begin{array}{l}0.0011 \\
(2.45)\end{array}$ & & $\begin{array}{l}0.0005 \\
(2.22)\end{array}$ & & & & & $\begin{array}{l}0.0007 \\
(3.47)\end{array}$ & $\begin{array}{l}0.0004 \\
(1.31)\end{array}$ & $\begin{array}{l}0.0006 \\
(1.64)\end{array}$ & $\begin{array}{l}0.0004 \\
(3.79)\end{array}$ & & $\begin{array}{c}0.0006 \\
(4.35)\end{array}$ \\
\hline $\bar{R}^{2}$ & 0.99 & 0.53 & 0.57 & 0.67 & 0.30 & 0.26 & 0.68 & 0.47 & 0.76 & 0.93 & 0.34 & 0.46 & 0.43 \\
\hline
\end{tabular}




\section{A.4 Labour market and physical capital stock: business employment}

$$
\begin{aligned}
\Delta \log l h_{b, t}= & \alpha\left\{\log l h_{b, t-1}-\log y_{b, t-1}-\sigma \log \frac{w h_{b, t-1}}{p_{y b, t-1}}+(\sigma+1) \eta(t-1)\right\} \\
& +\sum_{i=1}^{4} \gamma_{1, i} \Delta \log l h_{b, t-i}+\sum_{i=0}^{3} \gamma_{2, i} \Delta \log y_{b, t-i}+\sum_{i=0}^{3} \gamma_{3, i} \Delta \log \frac{w h_{b, t-i}}{p_{y b, t-i}}
\end{aligned}
$$

with

$l h_{b}=$ business employment (in labour hours)

$y_{b}=$ business production in real terms, value added at factor costs

$w h_{b}=$ non-government wage rate (per hour)

$p_{y b}=$ price deflator business production, value added at factor costs (index, 1990=100)

$t=$ deterministic linear trend 
Table 3 Parameter estimates of the business employment equations

\begin{tabular}{|c|c|c|c|c|c|c|c|c|c|c|c|c|c|}
\hline & $\mathrm{AU}$ & $\mathrm{BE}$ & $\mathrm{DE}$ & DK & ES & FI & FR & IT & $\mathrm{NL}$ & SW & UK & JP & US \\
\hline$L T(\alpha)$ & $\begin{array}{l}-0.14 \\
(4.31)\end{array}$ & $\begin{array}{c}-0.05 \\
(-)\end{array}$ & $\begin{array}{l}-0.10 \\
(3.91)\end{array}$ & $\begin{array}{c}-0.05 \\
(-)\end{array}$ & $\begin{array}{c}-0.04 \\
(-)\end{array}$ & $\begin{array}{l}-0.30 \\
(5.90)\end{array}$ & $\begin{array}{c}-0.08 \\
(-)\end{array}$ & $\begin{array}{c}-0.10 \\
(-)\end{array}$ & $\begin{array}{c}-0.06 \\
(-)\end{array}$ & $\begin{array}{l}-0.07 \\
(6.09)\end{array}$ & $\begin{array}{l}-0.06 \\
(2.27)\end{array}$ & $\begin{array}{c}-0.05 \\
(-)\end{array}$ & $\begin{array}{l}-0.25 \\
(8.04)\end{array}$ \\
\hline$\sigma \log \frac{w h_{b, t-1}}{p_{y b, t-1}}$ & $\begin{array}{l}-0.41 \\
(2.37)\end{array}$ & $\begin{array}{l}-0.87 \\
(5.57)\end{array}$ & $\begin{array}{l}-0.31 \\
(4.29)\end{array}$ & $\begin{array}{c}-1.00 \\
(-)\end{array}$ & $\begin{array}{c}-1.00 \\
(-)\end{array}$ & $\begin{array}{l}-0.20 \\
(2.36)\end{array}$ & & $\begin{array}{l}-0.51 \\
(1.83)\end{array}$ & $\begin{array}{l}-0.31 \\
(2.02)\end{array}$ & $\begin{array}{l}-0.44 \\
(1.96)\end{array}$ & $\begin{array}{l}-0.58 \\
(2.04)\end{array}$ & & $\begin{array}{l}-0.62 \\
(10.1)\end{array}$ \\
\hline$\sigma_{\frac{1}{4}} \sum_{i=1}^{4} \log \frac{w h_{b, t-i}}{p_{y, t, t-i}}$ & & & & & & & $\begin{array}{c}-0.68 \\
(3.78)\end{array}$ & & & & & $\begin{array}{c}-1.00 \\
(-)\end{array}$ & \\
\hline$\sigma$ & $\begin{array}{l}-0.41 \\
(2.37)\end{array}$ & $\begin{array}{l}-0.87 \\
(5.57)\end{array}$ & $\begin{array}{l}-0.31 \\
(4.29)\end{array}$ & $\begin{array}{c}-1.00 \\
(-)\end{array}$ & $\begin{array}{c}-1.00 \\
(-)\end{array}$ & $\begin{array}{l}-0.20 \\
(2.36)\end{array}$ & $\begin{array}{l}-0.68 \\
(3.78)\end{array}$ & $\begin{array}{l}-0.51 \\
(1.83)\end{array}$ & $\begin{array}{l}-0.31 \\
(2.02)\end{array}$ & $\begin{array}{l}-0.44 \\
(1.96)\end{array}$ & $\begin{array}{l}-0.58 \\
(2.04)\end{array}$ & $\begin{array}{c}-1.00 \\
(-)\end{array}$ & $\begin{array}{l}-0.62 \\
(10.1)\end{array}$ \\
\hline$\eta$ & $\begin{array}{l}0.008 \\
(13.6)\end{array}$ & $\begin{array}{l}0.008 \\
(1.57)\end{array}$ & $\begin{array}{l}0.006 \\
(17.3)\end{array}$ & & & $\begin{array}{l}0.009 \\
(24.9)\end{array}$ & $\begin{array}{l}0.006 \\
(6.15)\end{array}$ & $\begin{array}{l}0.008 \\
(3.30)\end{array}$ & $\begin{array}{l}0.004 \\
(11.23)\end{array}$ & $\begin{array}{l}0.006 \\
(7.65)\end{array}$ & $\begin{array}{l}0.003 \\
(2.17)\end{array}$ & & $\begin{array}{l}0.004 \\
(19.3)\end{array}$ \\
\hline$\Delta \log l h_{b, t-1}$ & & $\begin{array}{c}0.14 \\
(2.09)\end{array}$ & & $\begin{array}{c}0.18 \\
(1.96)\end{array}$ & $\begin{array}{c}0.71 \\
(14.07)\end{array}$ & & & & $\begin{array}{l}0.22 \\
(2.03)\end{array}$ & $\begin{array}{c}0.50 \\
(5.62)\end{array}$ & & & \\
\hline$\Delta \log l h_{b, t-2}$ & & $\begin{array}{c}0.14 \\
(2.66)\end{array}$ & & & & & & & & & & & \\
\hline$\Delta \log l h_{b, t-3}$ & & & & & & & & $\begin{array}{c}0.14 \\
(2.43)\end{array}$ & & & & & \\
\hline$\Delta \log l h_{b, t-4}$ & $\begin{array}{c}0.13 \\
(1.36)\end{array}$ & & & & & $\begin{array}{c}0.17 \\
(1.66)\end{array}$ & & $\begin{array}{l}0.16 \\
(2.81)\end{array}$ & $\begin{array}{c}0.44 \\
(4.09)\end{array}$ & & $\begin{array}{l}0.27 \\
(3.43)\end{array}$ & $\begin{array}{l}0.54 \\
(6.00)\end{array}$ & \\
\hline$\Delta \log y_{b, t}$ & $\begin{array}{l}0.12 \\
(2.58)\end{array}$ & $\begin{array}{c}0.12 \\
(6.27)\end{array}$ & $\begin{array}{c}0.12 \\
(4.13)\end{array}$ & & & $\begin{array}{l}0.13 \\
(1.77)\end{array}$ & $\begin{array}{l}0.27 \\
(3.64)\end{array}$ & & & & $\begin{array}{l}0.34 \\
(5.79)\end{array}$ & & $\begin{array}{l}0.45 \\
(14.8)\end{array}$ \\
\hline$\Delta \log y_{b, t-1}$ & & $\begin{array}{c}0.04 \\
(2.56)\end{array}$ & & & & & & & & & $\begin{array}{c}0.10 \\
(1.51)\end{array}$ & & \\
\hline$\Delta \log y_{b, t-2}$ & & & & & & & & & & $\begin{array}{c}0.05 \\
(5.18)\end{array}$ & $\begin{array}{c}0.15 \\
(2.58)\end{array}$ & & \\
\hline$\Delta \log y_{b, t-3}$ & & & & & & & $\begin{array}{c}0.31 \\
(3.95)\end{array}$ & & & $\begin{array}{c}0.03 \\
(3.70)\end{array}$ & & & \\
\hline$\frac{1}{4} \sum_{i=0}^{3} \Delta \log y_{b . t-i}$ & & & & $\begin{array}{c}0.18 \\
(1.53)\end{array}$ & & & & & $\begin{array}{c}0.21 \\
(3.77)\end{array}$ & & & & \\
\hline$\frac{1}{4} \sum_{i=1}^{4} \Delta \log y_{b . t-i}$ & & & & & $\begin{array}{c}0.25 \\
(-)\end{array}$ & & & & & & & $\begin{array}{c}0.13 \\
(1.32)\end{array}$ & \\
\hline$\Delta \log \frac{w h_{b, t}}{p_{y b, t}}$ & $\begin{array}{c}-0.12 \\
(3.71)\end{array}$ & & & & $\begin{array}{l}-0.10 \\
(1.82)\end{array}$ & & & $\begin{array}{l}-0.49 \\
(7.28)\end{array}$ & & & $\begin{array}{l}-0.50 \\
(9.15)\end{array}$ & & $\begin{array}{l}-0.48 \\
(6.95)\end{array}$ \\
\hline$\Delta \log \frac{w h_{b, t-3}}{p_{y b, t-3}}$ & & & & & & & & & & $\begin{array}{l}-0.02 \\
(2.15)\end{array}$ & & & \\
\hline$\frac{1}{4} \sum_{i=0}^{3} \Delta \log \frac{w h_{b . t-i}}{p_{y b . t-i}}$ & & & $\begin{array}{l}-0.24 \\
(6.84)\end{array}$ & & & & $\begin{array}{l}-0.18 \\
(1.58)\end{array}$ & & & & & $\begin{array}{l}-0.23 \\
(1.98)\end{array}$ & \\
\hline $\bar{R}^{2}$ & 0.95 & 0.81 & 0.94 & 0.62 & 0.84 & 0.96 & 0.62 & 0.87 & 0.76 & 0.65 & 0.77 & 0.96 & 0.73 \\
\hline
\end{tabular}




\section{A.5 Private consumption}

$$
\begin{aligned}
\Delta \log c_{t}= & \alpha\left\{\log c_{t-1}-\beta \log \frac{P D I_{t-1}}{p_{c, t-1}}-(1-\beta) \log \frac{N W_{M V, t-1}}{p_{c, t-1}}\right\} \\
& +\gamma_{1}\left(r_{l, t-2}-\dot{p}_{c, t-2}\right)+\sum_{i=1}^{4} \gamma_{2, i} \Delta \log c_{t-i}+\sum_{i=0}^{7} \gamma_{3, i} \Delta \log \frac{P D I_{t-i}}{p_{c, t-i}} \\
& +\sum_{i=0}^{4} \gamma_{4, i}\left(\Delta r_{l, t-i}-\Delta \dot{p}_{c, t-i}\right)+\sum_{i=0}^{4} \gamma_{5, i} \Delta r_{l, t-i}+\sum_{i=0}^{4} \gamma_{6, i} \Delta r_{s, t-1} \\
& +\sum_{i=0}^{4} \gamma_{8, i} \Delta u_{t-i}
\end{aligned}
$$

with

$$
\begin{array}{ll}
c & =\text { private consumption in real terms } \\
P D I & =\text { personal disposable income } \\
p_{c} & =\text { price deflator private consumption (index, 1990=100) } \\
N W_{M V} & =\text { net wealth private sector at market value } \\
r_{l} & =\text { nominal long-term interest rate (in \%) } \\
\dot{p}_{c} & =\text { inflation (in \%) } \\
r_{s} & =\text { nominal short-term interest rate (in \%) } \\
u & =\text { unemployment rate (in } \%)
\end{array}
$$


Table 4 Parameter estimates of the private consumption equations

\begin{tabular}{|c|c|c|c|c|c|c|c|c|c|c|c|c|c|}
\hline & $\mathrm{AU}$ & $\mathrm{BE}$ & $\mathrm{DE}$ & $\underline{\mathrm{DK}}$ & ES & FI & FR & IT & $\mathrm{NL}$ & SW & UK & JP & US \\
\hline$L T(\alpha)$ & $\begin{array}{l}-0.10 \\
(2.12)\end{array}$ & $\begin{array}{c}-0.03 \\
(-)\end{array}$ & $\begin{array}{l}-0.06 \\
(-)\end{array}$ & $\begin{array}{l}-0.13 \\
(2.51)\end{array}$ & $\begin{array}{c}-0.03 \\
(-)\end{array}$ & $\begin{array}{l}-0.04 \\
(1.09)\end{array}$ & $\begin{array}{l}-0.05 \\
(-)\end{array}$ & $\begin{array}{l}-0.02 \\
(2.49)\end{array}$ & $\begin{array}{l}-0.12 \\
(2.70)\end{array}$ & $\begin{array}{l}-0.05 \\
(1.19)\end{array}$ & $\begin{array}{l}-0.09 \\
(2.53)\end{array}$ & $\begin{array}{l}-0.06 \\
(2.49)\end{array}$ & $\begin{array}{l}-0.12 \\
(3.63)\end{array}$ \\
\hline $\log \frac{P D I_{t-1}}{p_{c . t-1}}$ & $\begin{array}{c}0.96 \\
(30.5)\end{array}$ & $\begin{array}{c}0.97 \\
(-)\end{array}$ & & $\begin{array}{c}0.85 \\
(7.45)\end{array}$ & $\begin{array}{c}0.93 \\
(4.50)\end{array}$ & $\begin{array}{c}0.94 \\
(5.30)\end{array}$ & $\begin{array}{c}0.97 \\
(-)\end{array}$ & $\begin{array}{l}0.78 \\
(7.11)\end{array}$ & $\begin{array}{c}0.88 \\
(21.37)\end{array}$ & $\begin{array}{l}0.94 \\
(4.14)\end{array}$ & $\begin{array}{l}0.71 \\
(8.25)\end{array}$ & $\begin{array}{r}0.95 \\
(-)\end{array}$ & $\begin{array}{c}0.79 \\
(34.74)\end{array}$ \\
\hline$\frac{1}{4} \sum_{i=1}^{4} \log \frac{P D I_{t-i}}{p_{c, t-i}}$ & & & $\begin{array}{c}0.95 \\
(-)\end{array}$ & & & & & & & & & & \\
\hline $\log \frac{N W_{M V, t}}{p_{c . t}}$ & & & & & & $\begin{array}{c}0.06 \\
(-)\end{array}$ & & & & & & & \\
\hline $\log \frac{N W_{M V . t-1}}{p_{c . t-1}}$ & $\begin{array}{c}0.04 \\
(-)\end{array}$ & $\begin{array}{c}0.03 \\
(-)\end{array}$ & $\begin{array}{l}0.05 \\
(-)\end{array}$ & $\begin{array}{c}0.15 \\
(-)\end{array}$ & $\begin{array}{c}0.07 \\
(-)\end{array}$ & & $\begin{array}{c}0.03 \\
(-)\end{array}$ & $\begin{array}{c}0.22 \\
(-)\end{array}$ & $\begin{array}{c}0.12 \\
(-)\end{array}$ & $\begin{array}{r}0.06 \\
(-)\end{array}$ & $\begin{array}{r}0.29 \\
(-)\end{array}$ & $\begin{array}{r}0.05 \\
(-)\end{array}$ & $\begin{array}{r}0.21 \\
(-)\end{array}$ \\
\hline$r_{l, t-2}-\dot{p}_{c_{t-2}}$ & & & & & $\begin{array}{l}-0.0007 \\
(1.74)\end{array}$ & $\begin{array}{c}-0.0009 \\
(1.65)\end{array}$ & & & & & & & \\
\hline$\Delta \log c_{t-1}$ & & & & $\begin{array}{l}-0.48 \\
(3.74)\end{array}$ & & & $\begin{array}{l}-0.30 \\
(2.41)\end{array}$ & $\begin{array}{l}0.40 \\
(3.56)\end{array}$ & $\begin{array}{l}-0.35 \\
(3.47)\end{array}$ & & & & \\
\hline$\Delta \log c_{t-2}$ & & & & & & $\begin{array}{l}-0.15 \\
(2.37)\end{array}$ & & & $\begin{array}{l}-0.36 \\
(5.51)\end{array}$ & $\begin{array}{l}-0.37 \\
(3.82)\end{array}$ & & $\begin{array}{l}0.27 \\
(3.30)\end{array}$ & \\
\hline$\Delta \log c_{t-3}$ & & & & & & & $\begin{array}{c}0.26 \\
(2.31)\end{array}$ & & & & & $\begin{array}{l}0.18 \\
(2.65)\end{array}$ & \\
\hline$\Delta \log c_{t-4}$ & $\begin{array}{l}0.51 \\
(4.66)\end{array}$ & & $\begin{array}{l}0.42 \\
(4.37)\end{array}$ & & & $\begin{array}{l}0.70 \\
(7.82)\end{array}$ & & & & $\begin{array}{l}0.30 \\
(3.34)\end{array}$ & & & \\
\hline$\Delta \log \frac{P D I_{t}}{p_{c . t}}$ & & $\begin{array}{c}0.37 \\
(7.30)\end{array}$ & $\begin{array}{c}0.24 \\
(4.57)\end{array}$ & $\begin{array}{c}0.31 \\
(1.61)\end{array}$ & & $\begin{array}{c}0.17 \\
(2.89)\end{array}$ & & & $\begin{array}{c}0.16 \\
(5.75)\end{array}$ & $\begin{array}{l}0.10 \\
(0.79)\end{array}$ & & & $\begin{array}{l}0.08 \\
(2.99)\end{array}$ \\
\hline$\Delta \log \frac{P D I_{t-1}}{p_{c . t-1}}$ & $\begin{array}{c}0.35 \\
(2.83)\end{array}$ & $\begin{array}{l}-0.18 \\
(2.62)\end{array}$ & & & & & & & & & & & \\
\hline$\Delta \log \frac{P D I_{t-2}}{P_{c . t-2}}$ & & & & & & & & & & & & & \\
\hline$\frac{1}{2} \sum_{i=0}^{1} \Delta \log \frac{P D I_{t-i}}{p_{c, t-i}}$ & & & & & & & & & & & $\begin{array}{c}0.18 \\
(2.64)\end{array}$ & & \\
\hline$\frac{1}{2} \sum_{i=2}^{3} \Delta \log \frac{P D I_{t-i}}{p_{c, t-i}}$ & & & & & & & $\begin{array}{c}0.20 \\
(1.45)\end{array}$ & & & & & & \\
\hline$\frac{1}{4} \sum_{i=4}^{7} \Delta \log \frac{P D I_{t-i}}{p_{c, t-i}}$ & & & & & $\begin{array}{c}0.12 \\
(1.15)\end{array}$ & & & & & & & & \\
\hline$\Delta r_{l . t-1}$ & & & & & $\begin{array}{l}-0.001 \\
(3.44)\end{array}$ & & & & & & & & $\begin{array}{l}-0.005 \\
(3.58)\end{array}$ \\
\hline$\Delta r_{l . t-2}$ & & & & $\begin{array}{l}-0.008 \\
(3.44)\end{array}$ & & & & & & $\begin{array}{l}-0.005 \\
(2.51)\end{array}$ & & $\begin{array}{l}-0.002 \\
(3.30)\end{array}$ & \\
\hline$\Delta r_{l . t-3}$ & & & & & & & & & & & & & \\
\hline$\Delta r_{l . t-4}$ & & & $\begin{array}{l}-0.004 \\
(1.87)\end{array}$ & & & & & & & & & & \\
\hline$\frac{1}{4} \sum_{i=1}^{4} \Delta r_{l, t-i}$ & & & & & & & & $\begin{array}{l}-0.001 \\
(2.50)\end{array}$ & & & & & \\
\hline$\Delta r_{s . t-1}$ & & & & & & $\begin{array}{l}-0.001 \\
(2.51)\end{array}$ & & & & & $\begin{array}{l}-0.002 \\
(3.01)\end{array}$ & & \\
\hline$\Delta r_{s . t-2}$ & & & & & & & & & & $\begin{array}{l}-0.003 \\
(2.51)\end{array}$ & & $\begin{array}{l}-0.002 \\
(3.30)\end{array}$ & \\
\hline$\Delta r_{s . t-3}$ & $\begin{array}{l}-0.008 \\
(2.42)\end{array}$ & & & & & & & & & & & & \\
\hline$\Delta u_{t-1}$ & & $\begin{array}{l}-0.004 \\
(1.75)\end{array}$ & & $\begin{array}{l}-0.012 \\
(2.28)\end{array}$ & $\begin{array}{l}-0.008 \\
(3.18)\end{array}$ & & & & $\begin{array}{l}-0.007 \\
(2.50)\end{array}$ & $\begin{array}{l}-0.007 \\
(1.48)\end{array}$ & $\begin{array}{l}-0.012 \\
(4.47)\end{array}$ & $\begin{array}{l}-0.027 \\
(4.29)\end{array}$ & $\begin{array}{l}-0.006 \\
(2.24)\end{array}$ \\
\hline$\Delta u_{t-3}$ & $\begin{array}{l}-0.019 \\
(2.45)\end{array}$ & & & & & & & & & & & & \\
\hline$\underline{\bar{R}^{2}}$ & 0.97 & 0.35 & 0.72 & 0.89 & 0.78 & 0.88 & 0.33 & 0.59 & 0.92 & 0.95 & 0.30 & 0.49 & 0.31 \\
\hline
\end{tabular}




\section{A.6 Housing investment}

$\begin{aligned} \Delta \log i_{h, t}= & \alpha\left\{\log i_{h, t-1}-\underline{d u m} \log \frac{P D I_{t-1}}{p_{c, t-1}}-(1-\underline{d u m}) \log \frac{P D I_{t-2}}{p_{c, t-2}}\right. \\ & \left.-\beta_{1}\left(r_{l, t-1}-\dot{p}_{c, t-1}\right)-\beta_{2}\left(r_{s, t-1}-\dot{p}_{c, t-1}\right)\right\}+\sum_{i=1}^{5} \gamma_{i} \Delta \log i_{h, t-i}+\xi t\end{aligned}$

with

$i_{h}=$ housing investment in real terms

$\underline{d u m}=1$ for AU, BE, DE, DK, FI, FR, IT, NL, SW, UK, JP, US

$=0$ for $\mathrm{ES}$

$P D I=$ personal disposable income

$p_{c}=$ price deflator private consumption (index, 1990=100)

$r_{l}=$ nominal long-term interest rate (in \%)

$\dot{p}_{c}=$ inflation (in \%)

$r_{s}=$ nominal short-term interest rate (in \%)

$t \quad=$ deterministic linear trend

Table 5 Parameter estimates of the housing investment equations

\begin{tabular}{|c|c|c|c|c|c|c|c|c|c|c|c|c|c|}
\hline & $\mathrm{AU}$ & $\mathrm{BE}$ & DE & DK & ES & FI & FR & IT & NL & SW & UK & $\mathrm{JP}$ & US \\
\hline$L T(\alpha)$ & $\begin{array}{c}-0.02 \\
(3.81)\end{array}$ & $\begin{array}{l}-0.04 \\
(3.58)\end{array}$ & $\begin{array}{l}-0.05 \\
(1.64)\end{array}$ & $\begin{array}{l}-0.04 \\
(6.83)\end{array}$ & $\begin{array}{l}-0.03 \\
(4.24)\end{array}$ & $\begin{array}{l}-0.06 \\
(2.03)\end{array}$ & $\begin{array}{l}-0.09 \\
(2.81)\end{array}$ & $\begin{array}{l}-0.02 \\
(3.19)\end{array}$ & $\begin{array}{c}-0.10 \\
(-)\end{array}$ & $\begin{array}{l}-0.02 \\
(2.37)\end{array}$ & $\begin{array}{l}-0.08 \\
(2.42)\end{array}$ & $\begin{array}{l}-0.10 \\
(2.31)\end{array}$ & $\begin{array}{l}-0.09 \\
(3.27)\end{array}$ \\
\hline$r_{l, t-1}-\dot{p}_{c, t-1}$ & $\begin{array}{c}-0.02 \\
(-)\end{array}$ & $\begin{array}{l}-0.06 \\
(3.05)\end{array}$ & $\begin{array}{c}-0.04 \\
(-)\end{array}$ & $\begin{array}{c}-0.02 \\
(1.18)\end{array}$ & $\begin{array}{c}-0.01 \\
(-)\end{array}$ & $\begin{array}{c}-0.08 \\
(-)\end{array}$ & $\begin{array}{l}-0.02 \\
(1.67)\end{array}$ & $\begin{array}{c}-0.01 \\
(-)\end{array}$ & $\begin{array}{c}-0.06 \\
(-)\end{array}$ & $\begin{array}{l}-0.10 \\
(1.77)\end{array}$ & & $\begin{array}{c}-0.01 \\
(-)\end{array}$ & $\begin{array}{l}-0.02 \\
(0.83)\end{array}$ \\
\hline$r_{s, t-1}-\dot{p}_{c, t-1}$ & & & & & & & & & & & $\begin{array}{c}-0.02 \\
(1.00)\end{array}$ & & \\
\hline$\Delta \log i_{h, t-1}$ & $\begin{array}{c}0.91 \\
(22.9)\end{array}$ & $\begin{array}{c}0.92 \\
(12.8)\end{array}$ & $\begin{array}{l}-0.23 \\
(5.39)\end{array}$ & $\begin{array}{c}0.94 \\
(21.1)\end{array}$ & $\begin{array}{c}0.90 \\
(-)\end{array}$ & $\begin{array}{l}-0.06 \\
(0.58)\end{array}$ & $\begin{array}{l}-0.22 \\
(1.73)\end{array}$ & $\begin{array}{c}0.89 \\
(18.1)\end{array}$ & & $\begin{array}{l}0.96 \\
(21.8)\end{array}$ & $\begin{array}{l}-0.21 \\
(2.32)\end{array}$ & $\begin{array}{l}0.30 \\
(2.66)\end{array}$ & $\begin{array}{l}0.53 \\
(4.34)\end{array}$ \\
\hline$\Delta \log i_{h, t-2}$ & & & $\begin{array}{l}-0.13 \\
(1.76)\end{array}$ & & & $\begin{array}{l}-0.27 \\
(3.55)\end{array}$ & $\begin{array}{c}0.20 \\
(1.14)\end{array}$ & & & & $\begin{array}{l}-0.16 \\
(1.35)\end{array}$ & & \\
\hline$\Delta \log i_{h, t-3}$ & & & $\begin{array}{l}-0.03 \\
(0.31)\end{array}$ & & & $\begin{array}{l}-0.09 \\
(0.90)\end{array}$ & $\begin{array}{c}0.02 \\
(0.16)\end{array}$ & & & & $\begin{array}{l}0.23 \\
(2.40)\end{array}$ & & \\
\hline$\Delta \log i_{h, t-4}$ & & & $\begin{array}{c}0.52 \\
(4.76)\end{array}$ & & & $\begin{array}{c}0.50 \\
(5.41)\end{array}$ & $\begin{array}{l}-0.02 \\
(0.17)\end{array}$ & & & & $\begin{array}{l}0.18 \\
(2.07)\end{array}$ & & \\
\hline$\Delta \log i_{h, t-5}$ & & & & & & & $\begin{array}{c}0.27 \\
(2.92)\end{array}$ & & & & & & \\
\hline$t$ & & & $\begin{array}{l}0.0003 \\
(1.30)\end{array}$ & $\begin{array}{c}-0.0003 \\
(3.58)\end{array}$ & & & $\begin{array}{c}-0.0006 \\
(2.54)\end{array}$ & & & & & $\begin{array}{c}-0.0006 \\
(1.78)\end{array}$ & \\
\hline $\bar{R}^{2}$ & 0.86 & 0.82 & 0.88 & 0.90 & 0.88 & 0.94 & 0.26 & 0.86 & 0.65 & 0.87 & 0.20 & 0.76 & 0.47 \\
\hline
\end{tabular}




\section{A.7 National income: total final expenditures}

$$
\begin{aligned}
\Delta y_{t f e, t}= & \alpha\left\{y_{t f e, t-1}-\beta_{1} s_{t-1}-\beta_{2} \frac{d u m_{t-1}}{t} s_{t-1}-\beta_{3} v_{t-2}\right\} \\
& +\gamma_{1} \Delta s_{t}+\gamma_{2} \underline{d u m}_{t} t \Delta s_{t}+\gamma_{3}\left(\Delta r_{l, t}-\Delta \dot{p}_{c, t}\right)+\gamma_{4}\left(\Delta r_{l, t}-100 \Delta \Delta_{4} \log p_{m, t}\right)
\end{aligned}
$$

with

$y_{t f e}=$ total final expenditures in real terms

$s \quad=\quad$ sales in real terms

$\underline{\text { dum }}=1$ from 1980 onwards for UK, JP and DE, NL

$=1$ from 1985 onwards for $\mathrm{BE}$

$=0$ otherwise

$t=$ deterministic linear trend

$v_{t} \quad=$ inventory stock in real terms

$r_{l} \quad=$ nominal long-term interest rate (in \%)

$\dot{p}_{c}=$ inflation (in \%)

$p_{m}=$ price deflator imports of goods and services (index, 1990=100)

\begin{tabular}{|c|c|c|c|c|c|c|c|c|c|c|c|c|c|}
\hline & $\mathrm{AU}$ & $\mathrm{BE}$ & $\mathrm{DE}$ & DK & ES & FI & FR & IT & NL & SW & UK & JP & US \\
\hline$L T(\alpha)$ & $\begin{array}{c}-0.88 \\
(9.59)\end{array}$ & $\begin{array}{c}-0.22 \\
(3.06)\end{array}$ & $\begin{array}{c}-0.52 \\
(6.07)\end{array}$ & $\begin{array}{c}-0.86 \\
(6.88)\end{array}$ & $\begin{array}{l}-0.19 \\
(3.01)\end{array}$ & $\begin{array}{c}-0.17 \\
(3.81)\end{array}$ & $\begin{array}{l}-0.29 \\
(4.44)\end{array}$ & $\begin{array}{c}-0.55 \\
(10.7)\end{array}$ & $\begin{array}{c}-0.73 \\
(6.67)\end{array}$ & $\begin{array}{l}-0.71 \\
(6.04)\end{array}$ & $\begin{array}{l}-0.44 \\
(5.46)\end{array}$ & $\begin{array}{l}-0.75 \\
(8.19)\end{array}$ & $\begin{array}{l}-0.16 \\
(1.25)\end{array}$ \\
\hline$s_{t-1}$ & $\begin{array}{c}1.09 \\
(39.3)\end{array}$ & $\begin{array}{c}1.06 \\
(49.9)\end{array}$ & $\begin{array}{c}1.03 \\
(65.4)\end{array}$ & $\begin{array}{c}1.03 \\
(78.9)\end{array}$ & $\begin{array}{c}1.06 \\
(26.5)\end{array}$ & $\begin{array}{c}1.03 \\
(21.4)\end{array}$ & $\begin{array}{c}1.04 \\
(86.9)\end{array}$ & $\begin{array}{c}1.18 \\
(22.4)\end{array}$ & $\begin{array}{c}1.04 \\
(33.9)\end{array}$ & $\begin{array}{c}0.92 \\
(54.0)\end{array}$ & $\begin{array}{c}1.14 \\
(39.1)\end{array}$ & $\begin{array}{l}1.08 \\
(95.4)\end{array}$ & $\begin{array}{c}1.10 \\
(38.2)\end{array}$ \\
\hline$\underline{d u m}_{t-1} t s_{t-1}$ & & $\begin{array}{c}-0.0002 \\
(2.86)\end{array}$ & & & & & & & & & $\begin{array}{c}-0.0005 \\
(4.54)\end{array}$ & $\begin{array}{c}-0.0001 \\
(2.97)\end{array}$ & \\
\hline$v_{t-2}$ & $\begin{array}{l}-0.11 \\
(3.02)\end{array}$ & $\begin{array}{c}-0.07 \\
(3.27)\end{array}$ & $\begin{array}{c}-0.05 \\
(1.94)\end{array}$ & $\begin{array}{c}-0.13 \\
(3.02)\end{array}$ & $\begin{array}{c}-0.11 \\
(2.18)\end{array}$ & $\begin{array}{c}-0.06 \\
(-)\end{array}$ & $\begin{array}{c}-0.06 \\
(-)\end{array}$ & $\begin{array}{l}-0.15 \\
(3.47)\end{array}$ & $\begin{array}{l}-0.08 \\
(1.24)\end{array}$ & $\begin{array}{c}-0.06 \\
(-)\end{array}$ & $\begin{array}{l}-0.26 \\
(4.03)\end{array}$ & $\begin{array}{l}-0.14 \\
(7.50)\end{array}$ & $\begin{array}{c}-0.18 \\
(-)\end{array}$ \\
\hline$\Delta s_{t}$ & $\begin{array}{c}0.92 \\
(16.9)\end{array}$ & $\begin{array}{c}1.17 \\
(38.6)\end{array}$ & $\begin{array}{c}0.98 \\
(13.5)\end{array}$ & $\begin{array}{c}0.74 \\
(6.85)\end{array}$ & $\begin{array}{c}1.03 \\
(41.1)\end{array}$ & $\begin{array}{c}0.99 \\
(16.3)\end{array}$ & $\begin{array}{c}0.86 \\
(13.7)\end{array}$ & $\begin{array}{c}0.93 \\
(11.1)\end{array}$ & $\begin{array}{c}0.85 \\
(15.6)\end{array}$ & $\begin{array}{c}0.84 \\
(8.03)\end{array}$ & $\begin{array}{c}0.89 \\
(16.5)\end{array}$ & $\begin{array}{c}0.90 \\
(16.8)\end{array}$ & $\begin{array}{c}1.03 \\
(16.7)\end{array}$ \\
\hline$\underline{d u m}_{t} t \Delta s_{t}$ & & $\begin{array}{l}-0.001 \\
(2.09)\end{array}$ & $\begin{array}{l}-0.001 \\
(2.13)\end{array}$ & & & & & & $\begin{array}{l}-0.001 \\
(1.64)\end{array}$ & & & & \\
\hline$\Delta r_{l, t}-\Delta \dot{p}_{c, t}$ & $\begin{array}{c}-680.9 \\
(1.01)\end{array}$ & $\begin{array}{c}-1433.8 \\
(2.48)\end{array}$ & & & & $\begin{array}{c}-304.6 \\
(2.60)\end{array}$ & & $\begin{array}{c}-355.0 \\
(2.34)\end{array}$ & & $\begin{array}{r}-216.3 \\
(1.08)\end{array}$ & & & \\
\hline$\Delta r_{l, t}-100 \Delta \Delta_{4} \log p_{m, t}$ & & & & & & & $\begin{array}{c}-0.39 \\
(2.20)\end{array}$ & & $\begin{array}{c}-43.3 \\
(1.15)\end{array}$ & & & & \\
\hline $\bar{R}^{2}$ & 0.98 & 0.99 & 0.96 & 0.91 & 0.99 & 0.96 & 0.67 & 0.64 & 0.96 & 0.97 & 0.76 & 0.93 & 0.74 \\
\hline
\end{tabular}

Table 6 Parameter estimates of the total final expenditures equations 


\section{A.8 Foreign trade: exports}

$\Delta \log x_{t}=\alpha\left\{\log x_{t-1}-\log m_{t-1}^{w}-\beta \log \frac{p_{x, t-1}}{p_{x, t-1}^{w}}\right\}+\gamma_{1} \Delta \log m_{t-1}^{w}+\gamma_{2} \Delta \log \frac{p_{x, t-1}}{p_{x, t-1}^{w}}$

with

$x=$ exports goods and services in real terms

$m^{w}=$ relevant world trade (index, 1990=100)

$p_{x}=$ price deflator exports of goods and services (index, 1990=100)

$p_{x}^{w}=$ weighted export price (index, 1990=100)

Table 7 Parameter estimates of the exports equations

\begin{tabular}{|c|c|c|c|c|c|c|c|c|c|c|c|c|c|}
\hline & $\mathrm{AU}$ & $\mathrm{BE}$ & DE & DK & ES & FI & FR & IT & $\mathrm{NL}$ & SW & UK & JP & US \\
\hline$L T(\alpha)$ & $\begin{array}{l}-0.44 \\
(4.35)\end{array}$ & $\begin{array}{l}-0.18 \\
(1.76)\end{array}$ & $\begin{array}{l}-0.49 \\
(5.21)\end{array}$ & $\begin{array}{l}-0.08 \\
(2.46)\end{array}$ & $\begin{array}{c}-0.20 \\
(-)\end{array}$ & $\begin{array}{l}-0.16 \\
(2.96)\end{array}$ & $\begin{array}{l}-0.08 \\
(1.92)\end{array}$ & $\begin{array}{l}-0.20 \\
(2.16)\end{array}$ & $\begin{array}{l}-0.25 \\
(2.93)\end{array}$ & $\begin{array}{l}-0.12 \\
(1.91)\end{array}$ & $\begin{array}{l}-0.08 \\
(2.36)\end{array}$ & $\begin{array}{c}-0.10 \\
(-)\end{array}$ & $\begin{array}{l}-0.08 \\
(3.03)\end{array}$ \\
\hline $\log \frac{p_{x, t-1}}{p_{x, t-1}^{v}}$ & $\begin{array}{c}-0.70 \\
(-)\end{array}$ & $\begin{array}{c}-0.70 \\
(-)\end{array}$ & $\begin{array}{l}-0.77 \\
(11.6)\end{array}$ & $\begin{array}{c}-0.70 \\
(-)\end{array}$ & $\begin{array}{c}-0.70 \\
(-)\end{array}$ & $\begin{array}{c}-0.70 \\
(-)\end{array}$ & $\begin{array}{l}-0.88 \\
(1.25)\end{array}$ & $\begin{array}{c}-0.70 \\
(-)\end{array}$ & $\begin{array}{c}-0.70 \\
(-)\end{array}$ & $\begin{array}{c}-0.70 \\
(-)\end{array}$ & $\begin{array}{l}-0.72 \\
(1.41)\end{array}$ & $\begin{array}{c}-0.70 \\
(-)\end{array}$ & $\begin{array}{c}-0.80 \\
(-)\end{array}$ \\
\hline$\Delta \log m_{t-1}^{w}$ & & & & & $\begin{array}{c}0.47 \\
(1.45)\end{array}$ & & $\begin{array}{c}0.19 \\
(1.48)\end{array}$ & & & & & & $\begin{array}{c}0.38 \\
(4.01)\end{array}$ \\
\hline$\Delta \log \frac{p_{x, t-1}}{p_{x, t}^{N}, t}$ & & & & & $\begin{array}{l}-0.49 \\
(2.54)\end{array}$ & & & $\begin{array}{l}-0.32 \\
(2.12)\end{array}$ & & & & & \\
\hline $\bar{R}^{2}$ & 0.61 & 0.06 & 0.53 & 0.09 & 0.06 & 0.62 & 0.10 & 0.11 & 0.64 & 0.72 & 0.06 & & 0.34 \\
\hline
\end{tabular}




\section{A.9 Foreign trade: imports}

$$
\begin{aligned}
\Delta \log m_{t}= & \alpha\left\{\log m_{t-1}-\log s_{t-1}-\beta \log \frac{p_{m, t-1}}{p_{y, t-1}}\right\} \\
& +\sum_{i=1}^{4} \gamma_{1, i} \Delta \log m_{t-i}+\gamma_{2} \Delta \log s_{t-1}+\sum_{i=1}^{5} \gamma_{3, i} \operatorname{gap}_{t-i}+\gamma_{4} \frac{\Delta v_{t}}{s_{t}}+\xi t
\end{aligned}
$$

with

$m \quad=$ imports of goods and services in real terms

$s=$ sales in real terms

$p_{m} \quad=\quad$ import price goods and services (index, 1990=100)

$p_{y}=$ price deflator gross domestic product (index, 1990=100)

gap $=$ output gap (in \%)

$\Delta v=$ change in inventories in real terms

$t=$ deterministic linear trend 
Table 8 Parameter estimates of the imports equations

\begin{tabular}{|c|c|c|c|c|c|c|c|c|c|c|c|c|c|}
\hline & $\mathrm{AU}$ & $\mathrm{BE}$ & $\mathrm{DE}$ & DK & ES & FI & FR & IT & NL & SW & UK & JP & US \\
\hline$L T(\alpha)$ & $\begin{array}{l}-0.39 \\
(3.41)\end{array}$ & $\begin{array}{c}-0.50 \\
(3.53)\end{array}$ & $\begin{array}{c}-0.31 \\
(4.10)\end{array}$ & $\begin{array}{c}-0.47 \\
(4.53)\end{array}$ & $\begin{array}{c}-0.14 \\
(4.34)\end{array}$ & $\begin{array}{c}-0.94 \\
(3.35)\end{array}$ & $\begin{array}{c}-0.24 \\
(3.85)\end{array}$ & $\begin{array}{c}-0.44 \\
(4.88)\end{array}$ & $\begin{array}{l}-0.46 \\
(4.31)\end{array}$ & $\begin{array}{l}-0.28 \\
(2.86)\end{array}$ & $\begin{array}{c}-0.42 \\
(3.54)\end{array}$ & $\begin{array}{l}-0.08 \\
(2.13)\end{array}$ & $\begin{array}{c}-0.33 \\
(4.94)\end{array}$ \\
\hline $\log \frac{p_{m, t-1}}{p_{y, t-1}}$ & $\begin{array}{c}-0.06 \\
(-)\end{array}$ & $\begin{array}{l}-0.25 \\
(4.67)\end{array}$ & $\begin{array}{c}-0.10 \\
(-)\end{array}$ & $\begin{array}{l}-0.17 \\
(2.58)\end{array}$ & $\begin{array}{l}-0.38 \\
(6.31)\end{array}$ & $\begin{array}{c}-0.15 \\
(-)\end{array}$ & $\begin{array}{l}-0.33 \\
(3.80)\end{array}$ & $\begin{array}{l}-0.31 \\
(4.33)\end{array}$ & $\begin{array}{l}-0.13 \\
(2.25)\end{array}$ & $\begin{array}{c}-0.12 \\
(-)\end{array}$ & $\begin{array}{l}-0.32 \\
(3.31)\end{array}$ & $\begin{array}{l}-0.52 \\
(3.77)\end{array}$ & $\begin{array}{l}-0.73 \\
(4.61)\end{array}$ \\
\hline$\Delta \log m_{t-1}$ & $\begin{array}{l}-0.17 \\
(2.05)\end{array}$ & & & & $\begin{array}{c}0.66 \\
(9.21)\end{array}$ & & $\begin{array}{c}0.16 \\
(2.17)\end{array}$ & & & $\begin{array}{c}-0.29 \\
(1.95)\end{array}$ & & & \\
\hline$\Delta \log m_{t-2}$ & & & & $\begin{array}{c}0.21 \\
(2.45)\end{array}$ & & & $\begin{array}{c}0.25 \\
(3.40)\end{array}$ & $\begin{array}{c}0.15 \\
(1.65)\end{array}$ & $\begin{array}{l}-0.19 \\
(2.06)\end{array}$ & & & $\begin{array}{c}0.34 \\
(4.02)\end{array}$ & \\
\hline$\Delta \log m_{t-3}$ & & & & & & & $\begin{array}{c}0.02 \\
(0.18)\end{array}$ & & $\begin{array}{c}0.12 \\
(1.79)\end{array}$ & & $\begin{array}{c}0.19 \\
(2.22)\end{array}$ & $\begin{array}{c}0.16 \\
(1.88)\end{array}$ & \\
\hline$\Delta \log m_{t-4}$ & $\begin{array}{c}0.28 \\
(2.28)\end{array}$ & & & & & & $\begin{array}{l}-0.31 \\
(3.73)\end{array}$ & & $\begin{array}{c}0.24 \\
(3.21)\end{array}$ & $\begin{array}{c}0.16 \\
(2.74)\end{array}$ & $\begin{array}{l}-0.20 \\
(2.10)\end{array}$ & $\begin{array}{l}-0.20 \\
(1.62)\end{array}$ & $\begin{array}{c}0.10 \\
(1.53)\end{array}$ \\
\hline$\Delta \log s_{t-1}$ & $\begin{array}{c}0.19 \\
(1.56)\end{array}$ & & & $\begin{array}{c}0.58 \\
(2.53)\end{array}$ & & & & & & & $\begin{array}{c}0.99 \\
(3.30)\end{array}$ & & $\begin{array}{l}1.00 \\
(-)\end{array}$ \\
\hline $\operatorname{gap}_{t-1}$ & & $\begin{array}{l}0.001 \\
(0.67)\end{array}$ & & $\begin{array}{l}0.001 \\
(1.15)\end{array}$ & & $\begin{array}{l}0.001 \\
(0.84)\end{array}$ & $\begin{array}{c}0.001 \\
(-)\end{array}$ & $\begin{array}{l}0.003 \\
(1.36)\end{array}$ & $\begin{array}{c}0.001 \\
(-)\end{array}$ & $\begin{array}{c}0.001 \\
(-)\end{array}$ & & $\begin{array}{c}0.001 \\
(-)\end{array}$ & $\begin{array}{c}0.001 \\
(-)\end{array}$ \\
\hline $\operatorname{gap}_{t-2}$ & $\begin{array}{c}0.001 \\
(-)\end{array}$ & & $\begin{array}{c}0.005 \\
(-)\end{array}$ & & $\begin{array}{l}0.001 \\
(0.91)\end{array}$ & $\begin{array}{l}0.001 \\
(0.84)\end{array}$ & & & $\begin{array}{c}0.001 \\
(-)\end{array}$ & $\begin{array}{c}0.001 \\
(-)\end{array}$ & & $\begin{array}{c}0.001 \\
(-)\end{array}$ & \\
\hline $\operatorname{gap}_{t-3}$ & $\begin{array}{c}0.001 \\
(-)\end{array}$ & & & & $\begin{array}{l}0.001 \\
(0.91)\end{array}$ & $\begin{array}{l}0.001 \\
(0.84)\end{array}$ & & & $\begin{array}{c}0.001 \\
(-)\end{array}$ & $\begin{array}{c}0.001 \\
(-)\end{array}$ & $\begin{array}{l}0.002 \\
(1.49)\end{array}$ & $\begin{array}{c}0.001 \\
(-)\end{array}$ & \\
\hline $\operatorname{gap}_{t-4}$ & $\begin{array}{c}0.001 \\
(-)\end{array}$ & & & & $\begin{array}{l}0.001 \\
(0.91)\end{array}$ & $\begin{array}{l}0.001 \\
(0.84)\end{array}$ & & & $\begin{array}{c}0.001 \\
(-)\end{array}$ & $\begin{array}{c}0.001 \\
(-)\end{array}$ & & $\begin{array}{c}0.001 \\
(-)\end{array}$ & \\
\hline $\operatorname{gap}_{t-5}$ & $\begin{array}{c}0.001 \\
(-)\end{array}$ & & & & $\begin{array}{l}0.001 \\
(0.91)\end{array}$ & & & & & & & & \\
\hline$\frac{\Delta v_{t}}{s_{t}}$ & & $\begin{array}{c}0.88 \\
(-)\end{array}$ & $\begin{array}{l}0.95 \\
(-)\end{array}$ & $\begin{array}{l}0.20 \\
(-)\end{array}$ & & $\begin{array}{l}1.00 \\
(-)\end{array}$ & $\begin{array}{c}0.52 \\
(3.13)\end{array}$ & $\begin{array}{c}0.80 \\
(-)\end{array}$ & $\begin{array}{r}0.75 \\
(-)\end{array}$ & $\begin{array}{l}0.82 \\
(2.84)\end{array}$ & $\begin{array}{r}0.95 \\
(-)\end{array}$ & & $\begin{array}{r}1.00 \\
(-)\end{array}$ \\
\hline$t$ & $\begin{array}{l}0.002 \\
(3.20)\end{array}$ & $\begin{array}{l}0.001 \\
(3.07)\end{array}$ & $\begin{array}{l}0.001 \\
(4.23)\end{array}$ & $\begin{array}{l}0.001 \\
(2.83)\end{array}$ & $\begin{array}{l}0.001 \\
(4.15)\end{array}$ & $\begin{array}{l}0.003 \\
(2.52)\end{array}$ & $\begin{array}{l}0.001 \\
(3.73)\end{array}$ & $\begin{array}{l}0.001 \\
(3.31)\end{array}$ & $\begin{array}{l}0.001 \\
(3.19)\end{array}$ & $\begin{array}{l}0.001 \\
(3.15)\end{array}$ & $\begin{array}{l}0.001 \\
(2.88)\end{array}$ & & $\begin{array}{l}0.001 \\
(3.09)\end{array}$ \\
\hline $\bar{R}^{2}$ & 0.74 & 0.34 & 0.57 & 0.68 & 0.71 & 0.68 & 0.36 & 0.33 & 0.45 & 0.79 & 0.39 & 0.34 & 0.50 \\
\hline
\end{tabular}





\section{A.10 Foreign trade: net exports primary income}

$\Delta N X_{P I, t}=\alpha\left\{N X_{P I, t-1}-\beta \frac{1}{3200} \sum_{i=1}^{8} r_{l, t-i}^{w} N F A_{t-1}\right\}+\gamma \Delta N X_{P I, t-1}$

with

$N X_{P I}=$ net exports primary income

$r_{l}^{w}=$ world nominal long-term interest rate (in \%)

$N F A=$ net foreign assets owned by the private sector

Table 9 Parameter estimates of the net exports primary income equations

\begin{tabular}{|c|c|c|c|c|c|c|c|c|c|c|c|c|c|}
\hline & $\mathrm{AU}$ & $\mathrm{BE}$ & $\mathrm{DE}$ & DK & ES & FI & FR & IT & NL & SW & UK & JP & US \\
\hline$L T(\alpha)$ & $\begin{array}{c}-0.69 \\
(4.72)\end{array}$ & $\begin{array}{c}-0.12 \\
(1.56)\end{array}$ & $\begin{array}{c}-0.15 \\
(1.57)\end{array}$ & $\begin{array}{c}-0.19 \\
(2.29)\end{array}$ & $\begin{array}{c}-0.34 \\
(4.71)\end{array}$ & $\begin{array}{c}-0.07 \\
(1.81)\end{array}$ & $\begin{array}{l}-0.17 \\
(2.41)\end{array}$ & $\begin{array}{c}-0.02 \\
(0.70)\end{array}$ & $\begin{array}{c}-0.51 \\
(4.50)\end{array}$ & $\begin{array}{c}-0.04 \\
(1.06)\end{array}$ & $\begin{array}{c}-0.32 \\
(4.20)\end{array}$ & $\begin{array}{c}-0.44 \\
(4.50)\end{array}$ & $\begin{array}{l}-0.23 \\
(2.75)\end{array}$ \\
\hline$\frac{1}{3200} \sum_{i=1}^{8} r_{l . t-i}^{w} N F A_{t-1}$ & $\begin{array}{c}0.31 \\
(6.19)\end{array}$ & $\begin{array}{c}0.31 \\
(6.19)\end{array}$ & $\begin{array}{c}0.31 \\
(6.19)\end{array}$ & $\begin{array}{c}0.31 \\
(6.19)\end{array}$ & $\begin{array}{c}0.31 \\
(6.19)\end{array}$ & $\begin{array}{c}0.31 \\
(6.19)\end{array}$ & $\begin{array}{c}0.31 \\
(6.19)\end{array}$ & $\begin{array}{c}0.31 \\
(6.19)\end{array}$ & $\begin{array}{c}0.31 \\
(6.19)\end{array}$ & $\begin{array}{c}0.31 \\
(6.19)\end{array}$ & $\begin{array}{c}0.31 \\
(6.19)\end{array}$ & $\begin{array}{l}0.31 \\
(6.19)\end{array}$ & $\begin{array}{c}0.31 \\
(6.19)\end{array}$ \\
\hline$\Delta N X_{P I, t-1}$ & $\begin{array}{c}-0.19 \\
(1.66)\end{array}$ & $\begin{array}{c}-0.55 \\
(5.95)\end{array}$ & $\begin{array}{c}-0.37 \\
(3.36)\end{array}$ & $\begin{array}{c}-0.71 \\
(9.14)\end{array}$ & & & $\begin{array}{l}-0.35 \\
(3.47)\end{array}$ & $\begin{array}{c}-0.54 \\
(6.24)\end{array}$ & & $\begin{array}{l}-0.23 \\
(2.22)\end{array}$ & & & $\begin{array}{l}-0.14 \\
(1.29)\end{array}$ \\
\hline $\bar{R}^{2}$ & 0.55 & 0.47 & 0.23 & 0.62 & 0.22 & 0.32 & 0.32 & 0.39 & 0.42 & 0.28 & 0.39 & 0.41 & 0.50 \\
\hline
\end{tabular}




\section{A.11 Wages and prices: non-government wage rate}

$$
\begin{aligned}
\Delta \log w_{b, t}=\alpha & \left\{\log w_{b, t-1}-\log l p_{b, t-1}-\log \left(p_{c, t-1}^{\frac{1}{2}} p_{y b, t-1}^{\frac{1}{2}}\right)\right. \\
& \left.-\beta_{1} \log \left(1+\tau_{\text {dirp }, t-1}+\tau_{s s c, t-1}\right)-\beta_{2} u_{t-1}\right\} \\
& +\sum_{i=1}^{4} \gamma_{1, i} \Delta \log w_{b, t-i}+\left(1-\sum_{i=1}^{4} \gamma_{1, i}\right) \Delta \log \left(p_{c, t-i}^{\frac{1}{2}} p_{y b, t-i}^{\frac{1}{2}}\right) \\
& +\sum_{i=1}^{5} \gamma_{3, i} \Delta \log l p_{b, t-i}+\sum_{i=0}^{3} \gamma_{4, i} \Delta \log \left(1+\tau_{\text {dirp }, t-i}+\tau_{s s c, t-i}\right)+\sum_{i=1}^{4} \gamma_{5} \Delta u_{t-1}
\end{aligned}
$$

with

$w_{b}=$ non-government wage rate (per employee)

$p_{c}=$ price deflator private consumption (index, 1990=100)

$p_{y b}=$ price deflator business production, value added at factor costs (index, 1990=100)

$l p_{b} \quad=$ business labour productivity

$\tau_{\text {dirp }}=$ tax rate direct taxes

$\tau_{s s c}=$ tax rate social security contibrutions

$u=$ unemployment rate (in \%)

remark: ES is estimated in $\Delta_{4}$-specification 
Table 10 Parameter estimates of the non-government wage rate equations

\begin{tabular}{|c|c|c|c|c|c|c|c|c|c|c|c|c|c|}
\hline & $\mathrm{AU}$ & $\mathrm{BE}$ & $\mathrm{DE}$ & DK & ES & FI & FR & IT & NL & SW & UK & JP & US \\
\hline$L T(\alpha)$ & $\begin{array}{l}-0.18 \\
(3.67)\end{array}$ & $\begin{array}{c}-0.05 \\
(-)\end{array}$ & $\begin{array}{l}-0.16 \\
(2.72)\end{array}$ & $\begin{array}{c}-0.05 \\
(-)\end{array}$ & $\begin{array}{l}-0.19 \\
(4.99)\end{array}$ & $\begin{array}{l}-0.10 \\
(2.51)\end{array}$ & $\begin{array}{l}-0.07 \\
(2.58)\end{array}$ & $\begin{array}{c}-0.05 \\
(-)\end{array}$ & $\begin{array}{l}-0.05 \\
(1.91)\end{array}$ & $\begin{array}{l}-0.11 \\
(3.17)\end{array}$ & $\begin{array}{l}-0.10 \\
(3.37)\end{array}$ & $\begin{array}{l}-0.32 \\
(4.07)\end{array}$ & $\begin{array}{c}-0.05 \\
(-)\end{array}$ \\
\hline $\begin{array}{l}\log \left(1+\tau_{\text {dirp.t }-1}\right. \\
\left.+\tau_{s s c, t-1}\right)\end{array}$ & & $\begin{array}{c}0.10 \\
(-)\end{array}$ & & $\begin{array}{c}0.40 \\
(-)\end{array}$ & & & & & $\begin{array}{c}0.30 \\
(-)\end{array}$ & $\begin{array}{c}0.22 \\
(0.12)\end{array}$ & $\begin{array}{c}0.10 \\
(-)\end{array}$ & $\begin{array}{c}0.10 \\
(-)\end{array}$ & $\begin{array}{c}0.10 \\
(-)\end{array}$ \\
\hline $\begin{array}{l}\frac{1}{4} \sum_{i=1}^{4} \log (1+ \\
\left.\tau_{\text {dirp.t-i}}+\tau_{s s c, t-i}\right)\end{array}$ & $\begin{array}{c}0.10 \\
(-)\end{array}$ & & $\begin{array}{c}0.40 \\
(-)\end{array}$ & & & $\begin{array}{c}0.10 \\
(-)\end{array}$ & $\begin{array}{c}0.40 \\
(-)\end{array}$ & $\begin{array}{c}0.10 \\
(-)\end{array}$ & & & & & \\
\hline $\begin{array}{l}\log \left(1+\tau_{\text {dirp.t }-4}\right. \\
\left.+\tau_{s s c, t-4}\right)\end{array}$ & & & & & $\begin{array}{c}0.40 \\
(-)\end{array}$ & & & & & & & & \\
\hline$u_{t-1}$ & & $\begin{array}{l}-0.036 \\
(4.18)\end{array}$ & $\begin{array}{l}-0.009 \\
(3.40)\end{array}$ & & & & & & $\begin{array}{r}-0.025 \\
(1.44)\end{array}$ & & $\begin{array}{l}-0.016 \\
(3.86)\end{array}$ & $\underset{(-)}{-0.010}$ & \\
\hline$\frac{1}{4} \sum_{i=1}^{4} u_{t-i}$ & $\begin{array}{l}-0.016 \\
(3.91)\end{array}$ & & & & $\begin{array}{c}-0.014 \\
(8.82)\end{array}$ & $\begin{array}{r}-0.014 \\
(4.20)\end{array}$ & $\begin{array}{l}-0.023 \\
(2.93)\end{array}$ & $\begin{array}{l}-0.042 \\
(3.71)\end{array}$ & & $\begin{array}{r}-0.011 \\
(1.74)\end{array}$ & & & \\
\hline$\frac{1}{4} \sum_{i=2}^{5} u_{t-i}$ & & & & $\begin{array}{l}-0.012 \\
(1.15)\end{array}$ & & & & & & & & & $\begin{array}{l}-0.010 \\
(1.19)\end{array}$ \\
\hline$\Delta \log w_{b, t-1}$ & & & $\begin{array}{l}-0.26 \\
(2.44)\end{array}$ & $\begin{array}{c}0.25 \\
(1.36)\end{array}$ & & & & $\begin{array}{c}0.32 \\
(3.20)\end{array}$ & $\begin{array}{l}-0.23 \\
(2.54)\end{array}$ & & & & $\begin{array}{c}0.16 \\
(1.22)\end{array}$ \\
\hline$\Delta \log w_{b, t-4}$ & & & & & & $\begin{array}{c}0.55 \\
(5.45)\end{array}$ & $\begin{array}{c}0.23 \\
(2.77)\end{array}$ & & & $\begin{array}{c}0.36 \\
(3.08)\end{array}$ & & & \\
\hline$\Delta_{4} \log w_{b, t-1}$ & & & & & $\begin{array}{c}0.82 \\
(15.89)\end{array}$ & & & & & & & & \\
\hline$\frac{1}{4} \sum_{i=0}^{3} \Delta \log \left(p_{c, t-i}^{\frac{1}{2}}\right.$ & & & & & & & & & & & & & \\
\hline$\left.p_{y b, t-i}^{\frac{1}{2}}\right)$ & $\begin{array}{c}1.00 \\
(-)\end{array}$ & $\begin{array}{c}1.00 \\
(-)\end{array}$ & $\begin{array}{c}1.26 \\
(-)\end{array}$ & $\begin{array}{c}0.75 \\
(-)\end{array}$ & & & & & & & & $\begin{array}{c}1.00 \\
(-)\end{array}$ & $\begin{array}{c}0.84 \\
(-)\end{array}$ \\
\hline \multicolumn{14}{|l|}{$\frac{1}{2} \sum_{i=0}^{1} \Delta \log \left(p_{c, t-i}^{\frac{1}{2}}\right.$} \\
\hline$\left.p_{y b, t-i}^{\frac{1}{2}}\right)$ & & & & & & $\begin{array}{c}0.45 \\
(-)\end{array}$ & $\begin{array}{c}0.77 \\
(-)\end{array}$ & $\begin{array}{c}0.68 \\
(-)\end{array}$ & $\begin{array}{c}1.23 \\
(-)\end{array}$ & $\begin{array}{c}0.64 \\
(-)\end{array}$ & $\begin{array}{c}1.00 \\
(-)\end{array}$ & & \\
\hline$\Delta_{4} \log \left(p_{c . t-1}^{\frac{1}{2}} p_{y b, t-1}^{\frac{1}{2}}\right)$ & & & & & $\begin{array}{c}0.18 \\
(-)\end{array}$ & & & & & & & & \\
\hline$\frac{1}{4} \sum_{i=1}^{4} \Delta \log l p_{b . t-i}$ & & & $\begin{array}{c}0.42 \\
(1.29)\end{array}$ & & & & & & & & & & \\
\hline$\frac{1}{4} \sum_{i=2}^{5} \Delta \log l p_{b . t-i}$ & & & & & & $\begin{array}{c}0.62 \\
(2.34)\end{array}$ & & & & & & & \\
\hline$\Delta_{4} \log l p_{b . t-1}$ & & & & & $\begin{array}{c}0.34 \\
(4.29)\end{array}$ & & & & & & & & \\
\hline $\begin{array}{l}\frac{1}{4} \sum_{i=0}^{3} \Delta \log (1+ \\
\left.\tau_{\text {dirp.t-i}}+\tau_{s s c, t-i}\right)\end{array}$ & & & & & & & & & $\begin{array}{c}0.20 \\
(-)\end{array}$ & & & & \\
\hline$\Delta u_{t-1}$ & & $\begin{array}{r}-0.003 \\
(1.18)\end{array}$ & & $\begin{array}{l}-0.005 \\
(1.77)\end{array}$ & & & & & & & & $\begin{array}{l}-0.030 \\
(2.05)\end{array}$ & $\begin{array}{r}-0.005 \\
(2.84)\end{array}$ \\
\hline$\frac{1}{4} \sum_{i=1}^{4} \Delta u_{t-i}$ & $\begin{array}{l}-0.033 \\
(2.32)\end{array}$ & & & & & & & & & & & & \\
\hline $\bar{R}^{2}$ & 0.98 & 0.27 & 0.96 & 0.33 & 0.98 & 0.87 & 0.57 & 0.77 & 0.99 & 0.51 & 0.64 & 0.99 & 0.43 \\
\hline
\end{tabular}




\section{A.12 Wages and prices: price deflator private consumption}

$$
\begin{aligned}
\Delta \log p_{c, t}=\alpha & \left\{\log p_{c, t-1}-\beta_{1} \log u l c_{t-1}-\beta_{2}\left(\log \underline{p}_{\text {oil }, t-1} e_{D O L, t-1}\right)\right. \\
& \left.-\left(1-\beta_{1}-\beta_{2}\right) \log p_{m, t-1}-\log \left(1+\underline{\tau}_{i n d, t-1}\right)\right\} \\
+ & \sum_{i=1}^{4} \gamma_{1, i} \Delta \log p_{c, t-i}+\sum_{i=1}^{4} \gamma_{2, i} \Delta \log p_{m, t-i}+\sum_{i=0}^{3} \gamma_{3, i} \Delta \log \left(\underline{p}_{\text {oil }, t-i} e_{D O L, t-i}\right) \\
+ & \sum_{i=1}^{3} \gamma_{4, i} \Delta \log w_{b, t-i}+\sum_{i=1}^{2} \gamma_{5, i} \Delta g a p_{t-i}+\sum_{i=1}^{4} \gamma_{6, i} \Delta \log l_{b, t-i} \\
& +\left(1-\sum_{i=1}^{4} \gamma_{1, i}-\sum_{i=1}^{4} \gamma_{2, i}-\sum_{i=0}^{3} \gamma_{3, i}-\sum_{i=1}^{3} \gamma_{4, i}\right) \Delta \log w_{b, t} \\
& +\Delta \log \left(1+\underline{\tau}_{i n d, t}\right)-\sum_{i=1}^{4} \gamma_{1, i} \Delta \log \left(1+\underline{\tau}_{i n d, t-i}\right)
\end{aligned}
$$

with

$$
\begin{aligned}
& p_{c}=\text { deflator private consumption (index, 1990=100) } \\
& u l c=\text { unit labour costs } \\
& \underline{p}_{\text {oil }}=\text { spot price Brent per barrel (in USD, index, 1990=100) } \\
& e_{D O L}=\text { nominal exchange rate, domestic currency per USD } \\
& p_{m}=\text { deflator imports of goods and services (index, 1990=100) } \\
& \underline{\tau}_{\text {ind }}=\text { indirect tax rate } \\
& w_{b}=\text { business wage rate (per employee) } \\
& g a p=\text { output gap (in } \%) \\
& l p_{b}=\text { business labour productivity }
\end{aligned}
$$

remark: JP is estimated in $\Delta_{4}$-specification 
Table 11 Parameter estimates of the price deflator private consumption equations

\begin{tabular}{|c|c|c|c|c|c|c|c|c|c|c|c|c|c|}
\hline & $\mathrm{AU}$ & $\mathrm{BE}$ & $\mathrm{DE}$ & DK & ES & FI & FR & IT & $\mathrm{NL}$ & SW & UK & JP & US \\
\hline$L T(\alpha)$ & $\begin{array}{c}-0.08 \\
(-)\end{array}$ & $\begin{array}{c}-0.07 \\
(-)\end{array}$ & $\begin{array}{c}-0.08 \\
(-)\end{array}$ & $\begin{array}{c}-0.06 \\
(-)\end{array}$ & $\begin{array}{c}-0.05 \\
(-)\end{array}$ & $\begin{array}{c}-0.07 \\
(-)\end{array}$ & $\begin{array}{c}-0.08 \\
(-)\end{array}$ & $\begin{array}{c}-0.10 \\
(-)\end{array}$ & $\begin{array}{c}-0.08 \\
(-)\end{array}$ & $\begin{array}{c}-0.08 \\
(-)\end{array}$ & $\begin{array}{c}-0.05 \\
(-)\end{array}$ & $\begin{array}{l}-0.12 \\
(2.37)\end{array}$ & $\begin{array}{c}-0.10 \\
(-)\end{array}$ \\
\hline $\log u l c_{t-1}$ & & $\begin{array}{c}0.64 \\
(13.9)\end{array}$ & $\begin{array}{c}0.89 \\
(-)\end{array}$ & $\begin{array}{c}0.77 \\
(-)\end{array}$ & $\begin{array}{c}0.92 \\
(-)\end{array}$ & & & $\begin{array}{c}0.87 \\
(18.8)\end{array}$ & $\begin{array}{c}0.84 \\
(-)\end{array}$ & $\begin{array}{c}0.91 \\
(-)\end{array}$ & & & \\
\hline$\frac{1}{4} \sum_{i=1}^{4} \log u l c_{t-i}$ & $\begin{array}{c}0.86 \\
(-)\end{array}$ & & & & & $\begin{array}{c}0.81 \\
(-)\end{array}$ & $\begin{array}{c}0.89 \\
(-)\end{array}$ & & & & $\begin{array}{c}0.92 \\
(-)\end{array}$ & & $\begin{array}{c}0.90 \\
(-)\end{array}$ \\
\hline $\log u l c_{t-4}$ & & & & & & & & & & & & $\begin{array}{c}0.92 \\
(19.4)\end{array}$ & \\
\hline $\log \left(\underline{p}_{\text {oil.t-1 }} e_{D O L, t-1}\right)$ & $\begin{array}{c}0.01 \\
(-)\end{array}$ & $\begin{array}{c}0.01 \\
(-)\end{array}$ & $\begin{array}{c}0.01 \\
(-)\end{array}$ & $\begin{array}{c}0.01 \\
(-)\end{array}$ & $\begin{array}{c}0.01 \\
(-)\end{array}$ & $\begin{array}{c}0.01 \\
(-)\end{array}$ & $\begin{array}{c}0.01 \\
(-)\end{array}$ & $\begin{array}{r}0.01 \\
(-)\end{array}$ & $\begin{array}{r}0.01 \\
(-)\end{array}$ & $\begin{array}{r}0.01 \\
(-)\end{array}$ & $\begin{array}{r}0.01 \\
(-)\end{array}$ & & $\begin{array}{r}0.01 \\
(-)\end{array}$ \\
\hline $\log \left(\underline{p}_{o i l . t-4} e_{D O L, t-4}\right)$ & & & & & & & & & & & & $\begin{array}{c}0.01 \\
(-)\end{array}$ & \\
\hline $\log p_{m, t-1}$ & $\begin{array}{c}0.13 \\
(-)\end{array}$ & $\begin{array}{c}0.35 \\
(-)\end{array}$ & $\begin{array}{c}0.10 \\
(-)\end{array}$ & $\begin{array}{c}0.22 \\
(-)\end{array}$ & $\begin{array}{l}0.07 \\
(2.20)\end{array}$ & $\begin{array}{c}0.18 \\
(3.97)\end{array}$ & $\begin{array}{c}0.10 \\
(-)\end{array}$ & $\begin{array}{c}0.12 \\
(-)\end{array}$ & $\begin{array}{l}0.15 \\
(2.95)\end{array}$ & $\begin{array}{c}0.08 \\
(-)\end{array}$ & $\begin{array}{l}0.09 \\
(2.42)\end{array}$ & & $\begin{array}{c}0.09 \\
(-)\end{array}$ \\
\hline $\log p_{m, t-4}$ & & & & & & & & & & & & $\begin{array}{c}0.07 \\
(-)\end{array}$ & \\
\hline$\Delta \log p_{c . t-1}$ & & $\begin{array}{c}0.31 \\
(3.54)\end{array}$ & & $\begin{array}{c}0.36 \\
(3.69)\end{array}$ & $\begin{array}{c}0.83 \\
(7.69)\end{array}$ & $\begin{array}{c}0.18 \\
(1.78)\end{array}$ & & $\begin{array}{c}0.52 \\
(4.56)\end{array}$ & & & & & $\begin{array}{c}0.29 \\
(2.81)\end{array}$ \\
\hline$\Delta \log p_{c . t-2}$ & & $\begin{array}{c}0.34 \\
(3.74)\end{array}$ & & & $\begin{array}{c}-0.61 \\
(4.75)\end{array}$ & & $\begin{array}{c}0.29 \\
(3.90)\end{array}$ & & & & & & $\begin{array}{c}0.11 \\
(0.90)\end{array}$ \\
\hline$\Delta \log p_{c . t-3}$ & $\begin{array}{c}0.29 \\
(3.01)\end{array}$ & & & & $\begin{array}{c}0.43 \\
(3.89)\end{array}$ & & & & & & & & $\begin{array}{c}0.21 \\
(2.04)\end{array}$ \\
\hline$\Delta \log p_{c . t-4}$ & $\begin{array}{c}0.23 \\
(3.72)\end{array}$ & & $\begin{array}{c}0.31 \\
(4.08)\end{array}$ & $\begin{array}{c}0.29 \\
(3.25)\end{array}$ & & $\begin{array}{c}0.37 \\
(3.77)\end{array}$ & & & $\begin{array}{c}0.23 \\
(3.58)\end{array}$ & $\begin{array}{c}0.41 \\
(3.30)\end{array}$ & $\begin{array}{c}0.07 \\
(0.68)\end{array}$ & & \\
\hline$\Delta_{4} \log p_{c, t-1}$ & & & & & & & & & & & & $\begin{array}{c}0.56 \\
(5.77)\end{array}$ & \\
\hline$\Delta \log p_{m, t-1}$ & & & & & & & $\begin{array}{c}0.09 \\
(1.77)\end{array}$ & & & & & & \\
\hline$\frac{1}{4} \sum_{i=1}^{4} \Delta \log p_{m . t-i}$ & & & $\begin{array}{c}0.21 \\
(3.28)\end{array}$ & & $\begin{array}{c}0.07 \\
(2.20)\end{array}$ & & & & $\begin{array}{l}0.15 \\
(2.95)\end{array}$ & $\begin{array}{l}0.19 \\
(2.57)\end{array}$ & $\begin{array}{c}0.09 \\
(2.42)\end{array}$ & & \\
\hline$\frac{1}{4} \sum_{i=4}^{7} \Delta \log p_{m . t-i}$ & & & & & & $\begin{array}{c}0.18 \\
(3.97)\end{array}$ & & & & & & & \\
\hline$\Delta \log \left(\underline{p}_{o i l, t} e_{D O L, t}\right)$ & & $\begin{array}{c}0.02 \\
(4.43)\end{array}$ & $\begin{array}{c}0.01 \\
(2.14)\end{array}$ & & & $\begin{array}{c}0.01 \\
(1.75)\end{array}$ & & & & $\begin{array}{c}0.01 \\
(1.04)\end{array}$ & $\begin{array}{c}0.01 \\
(2.68)\end{array}$ & & $\begin{array}{c}0.01 \\
(4.77)\end{array}$ \\
\hline$\Delta \log \left(\underline{p}_{o i l, t-1} e_{D O L, t-1}\right)$ & & & & & & & & & & & & & $\begin{array}{c}0.01 \\
(2.22)\end{array}$ \\
\hline$\Delta_{4} \log \left(\underline{p}_{o i l, t-1} e_{D O L, t-1}\right)$ & & & & & & & & & & & & $\begin{array}{c}0.01 \\
(1.91)\end{array}$ & \\
\hline$\Delta \log w_{b, t}$ & & & & & & & $\begin{array}{c}0.62 \\
(-)\end{array}$ & & & & & & \\
\hline$\frac{1}{4} \sum_{i=0}^{3} \Delta \log w_{b, t-i}$ & $\begin{array}{c}0.48 \\
(-)\end{array}$ & $\begin{array}{c}0.33 \\
(-)\end{array}$ & $\begin{array}{c}0.47 \\
(-)\end{array}$ & $\begin{array}{c}0.35 \\
(-)\end{array}$ & $\begin{array}{c}0.28 \\
(-)\end{array}$ & $\begin{array}{c}0.26 \\
(-)\end{array}$ & & $\begin{array}{c}0.48 \\
(-)\end{array}$ & $\begin{array}{c}0.62 \\
(-)\end{array}$ & & $\begin{array}{c}0.83 \\
(-)\end{array}$ & & $\begin{array}{c}0.37 \\
(-)\end{array}$ \\
\hline$\frac{1}{4} \sum_{i=3}^{7} \Delta \log w_{b, t-i}$ & & & & & & & & & & $\begin{array}{c}0.39 \\
(-)\end{array}$ & & & \\
\hline$\frac{1}{4} \sum_{i=0}^{3} \Delta_{4} \log w_{b . t-i}$ & & & & & & & & & & & & $\begin{array}{c}0.43 \\
(-)\end{array}$ & \\
\hline$\frac{1}{100} \Delta \operatorname{gap}_{t-1}$ & & $\begin{array}{c}0.05 \\
(1.60)\end{array}$ & & & & & & & & & & & \\
\hline$\frac{1}{100} \Delta g_{a p} p_{t-2}$ & & & & & & $\begin{array}{c}0.03 \\
(1.55)\end{array}$ & & & & & & & \\
\hline$\Delta \log l p_{b, t-1}$ & & & & & & & $\begin{array}{l}-0.39 \\
(2.19)\end{array}$ & & & & & & \\
\hline$\frac{1}{4} \sum_{i=1}^{4} \Delta \log l p_{b . t-i}$ & & & & & $\begin{array}{l}-0.28 \\
(1.72)\end{array}$ & & & & & & & & \\
\hline$\Delta \log \left(1+\underline{\tau}_{i n d, t-1}\right)$ & & $\begin{array}{l}-0.31 \\
(3.54)\end{array}$ & & $\begin{array}{l}-0.36 \\
(3.69)\end{array}$ & $\begin{array}{l}-0.83 \\
(7.69)\end{array}$ & $\begin{array}{l}-0.18 \\
(1.78)\end{array}$ & & $\begin{array}{l}-0.52 \\
(4.56)\end{array}$ & & & & & $\begin{array}{l}-0.29 \\
(2.81)\end{array}$ \\
\hline$\Delta \log \left(1+\underline{\tau}_{i n d, t-2}\right)$ & & $\begin{array}{c}-0.34 \\
(3.74)\end{array}$ & & & $\begin{array}{c}0.61 \\
(4.75)\end{array}$ & & $\begin{array}{l}-0.29 \\
(3.90)\end{array}$ & & & & & & $\begin{array}{l}-0.11 \\
(0.90)\end{array}$ \\
\hline$\Delta \log \left(1+\underline{\tau}_{i n d, t-3}\right)$ & $\begin{array}{l}-0.23 \\
(3.72)\end{array}$ & & & & $\begin{array}{l}-0.43 \\
(3.89)\end{array}$ & & & & & & & & $\begin{array}{l}-0.21 \\
(2.04)\end{array}$ \\
\hline$\Delta \log \left(1+\underline{\tau}_{i n d, t-4}\right)$ & $\begin{array}{l}-0.29 \\
(3.01)\end{array}$ & & $\begin{array}{l}-0.31 \\
(4.09)\end{array}$ & $\begin{array}{l}-0.29 \\
(3.25)\end{array}$ & & $\begin{array}{l}-0.37 \\
(3.77)\end{array}$ & & & $\begin{array}{l}-0.23 \\
(3.58)\end{array}$ & $\begin{array}{l}-0.41 \\
(3.30)\end{array}$ & $\begin{array}{l}-0.07 \\
(0.68)\end{array}$ & & \\
\hline$\Delta_{4} \log \left(1+\underline{\tau}_{i n d, t-1}\right)$ & & & & & & & & & & & & $\begin{array}{l}-0.56 \\
(5.77)\end{array}$ & \\
\hline $\bar{R}^{2}$ & 0.67 & 0.74 & 0.44 & 0.34 & 0.81 & 0.77 & 0.38 & 0.89 & 0.63 & 0.29 & 0.66 & 0.87 & 0.83 \\
\hline
\end{tabular}





\section{A.13 Wages and prices: price deflator exports of goods and services}

$$
\begin{aligned}
\Delta \log p_{x, t}= & \alpha\left\{\log p_{x, t-1}-\beta \log p_{y, t-1}-(1-\beta) \log p_{x, t-1}^{w}\right\} \\
& +\sum_{i=1}^{4} \gamma_{1, i} \Delta \log p_{x, t-i}+\gamma_{2} \Delta \log p_{y, t-1}+\gamma_{3} \Delta \log p_{x, t-1}^{w}+\xi t
\end{aligned}
$$

with

$p_{x}=$ price deflator exports of goods and services (index, 1990=100)

$p_{y}=$ price deflator gross domestic product (index, 1990=100)

$p_{x}^{w}=$ weighted export price (index, 1990=100)

$t=$ deterministic linear trend

\begin{tabular}{|c|c|c|c|c|c|c|c|c|c|c|c|c|c|}
\hline & $\mathrm{AU}$ & $\mathrm{BE}$ & $\mathrm{DE}$ & DK & ES & FI & FR & IT & NL & SW & UK & JP & US \\
\hline$T(\alpha)$ & $\begin{array}{l}-0.66 \\
(4.03)\end{array}$ & $\begin{array}{c}-0.13 \\
(1.35)\end{array}$ & $\begin{array}{l}-0.05 \\
(1.70)\end{array}$ & $\begin{array}{l}-0.19 \\
(2.24)\end{array}$ & $\begin{array}{c}-0.06 \\
(2.44)\end{array}$ & $\begin{array}{c}-0.18 \\
(1.98)\end{array}$ & $\begin{array}{c}-0.06 \\
(1.89)\end{array}$ & $\begin{array}{l}-0.23 \\
(4.04)\end{array}$ & $\begin{array}{l}-0.10 \\
(2.52)\end{array}$ & $\begin{array}{l}-0.21 \\
(2.24)\end{array}$ & $\begin{array}{l}-0.08 \\
(1.91)\end{array}$ & $\begin{array}{l}-0.13 \\
(3.68)\end{array}$ & $\begin{array}{l}-0.05 \\
(2.18)\end{array}$ \\
\hline $\log p_{y, t-1}$ & $\begin{array}{c}0.62 \\
(16.5)\end{array}$ & $\begin{array}{c}0.40 \\
(2.26)\end{array}$ & $\begin{array}{c}0.79 \\
(25.3)\end{array}$ & $\begin{array}{c}0.54 \\
(4.49)\end{array}$ & $\begin{array}{c}0.67 \\
(4.92)\end{array}$ & $\begin{array}{c}0.55 \\
(4.84)\end{array}$ & $\begin{array}{c}0.65 \\
(17.4)\end{array}$ & $\begin{array}{c}0.42 \\
(4.15)\end{array}$ & $\begin{array}{c}0.38 \\
(2.49)\end{array}$ & $\begin{array}{c}0.34 \\
(2.56)\end{array}$ & $\begin{array}{c}0.67 \\
(4.01)\end{array}$ & $\begin{array}{c}1.00 \\
(-)\end{array}$ & $\begin{array}{l}0.57 \\
(2.13)\end{array}$ \\
\hline $\log p_{x, t-1}^{w}$ & $\begin{array}{c}0.38 \\
(-)\end{array}$ & $\begin{array}{c}0.60 \\
(-)\end{array}$ & $\begin{array}{c}0.21 \\
(-)\end{array}$ & $\begin{array}{c}0.46 \\
(-)\end{array}$ & $\begin{array}{c}0.33 \\
(-)\end{array}$ & $\begin{array}{c}0.45 \\
(-)\end{array}$ & $\begin{array}{c}0.35 \\
(-)\end{array}$ & $\begin{array}{c}0.58 \\
(-)\end{array}$ & $\begin{array}{r}0.62 \\
(-)\end{array}$ & $\begin{array}{c}0.66 \\
(-)\end{array}$ & $\begin{array}{r}0.33 \\
(-)\end{array}$ & & $\begin{array}{r}0.43 \\
(-)\end{array}$ \\
\hline$\Delta \log p_{x . t-1}$ & $\begin{array}{c}0.15 \\
(1.31)\end{array}$ & $\begin{array}{c}0.18 \\
(4.62)\end{array}$ & $\begin{array}{c}0.0004 \\
(0.01)\end{array}$ & $\begin{array}{c}0.04 \\
(0.37)\end{array}$ & $\begin{array}{c}1.04 \\
(11.2)\end{array}$ & $\begin{array}{c}0.38 \\
(4.59)\end{array}$ & & $\begin{array}{c}0.21 \\
(1.45)\end{array}$ & $\begin{array}{l}-0.03 \\
(0.24)\end{array}$ & $\begin{array}{l}-0.33 \\
(2.02)\end{array}$ & $\begin{array}{l}0.37 \\
(2.83)\end{array}$ & $\begin{array}{c}0.51 \\
(5.46)\end{array}$ & $\begin{array}{c}0.51 \\
(6.54)\end{array}$ \\
\hline$\Delta \log p_{x, t-2}$ & $\begin{array}{c}0.27 \\
(3.13)\end{array}$ & $\begin{array}{c}0.18 \\
(4.62)\end{array}$ & $\begin{array}{c}0.24 \\
(3.24)\end{array}$ & $\begin{array}{l}-0.09 \\
(1.41)\end{array}$ & $\begin{array}{l}-0.50 \\
(3.61)\end{array}$ & $\begin{array}{l}-0.13 \\
(1.49)\end{array}$ & & $\begin{array}{l}-0.10 \\
(1.23)\end{array}$ & $\begin{array}{c}0.19 \\
(4.34)\end{array}$ & $\begin{array}{c}0.20 \\
(1.62)\end{array}$ & $\begin{array}{l}0.008 \\
(0.03)\end{array}$ & $\begin{array}{c}0.21 \\
(2.58)\end{array}$ & \\
\hline$\Delta \log p_{x . t}$ & $\begin{array}{c}0.08 \\
(0.97)\end{array}$ & $\begin{array}{c}0.18 \\
(4.62)\end{array}$ & $\begin{array}{l}-0.23 \\
(4.30)\end{array}$ & $\begin{array}{l}-0.04 \\
(0.50)\end{array}$ & $\begin{array}{c}0.21 \\
(1.27)\end{array}$ & $\begin{array}{c}0.20 \\
(2.67)\end{array}$ & & $\begin{array}{c}0.18 \\
(1.74)\end{array}$ & $\begin{array}{l}-0.09 \\
(1.14)\end{array}$ & $\begin{array}{l}-0.07 \\
(0.57)\end{array}$ & $\begin{array}{c}0.26 \\
(2.19)\end{array}$ & $\begin{array}{c}0.09 \\
(0.77)\end{array}$ & \\
\hline$\Delta \log p_{x . t-4}$ & $\begin{array}{c}0.44 \\
(3.80)\end{array}$ & $\begin{array}{c}0.18 \\
(4.62)\end{array}$ & & $\begin{array}{c}0.33 \\
(3.62)\end{array}$ & $\begin{array}{c}0.02 \\
(0.15)\end{array}$ & $\begin{array}{c}0.14 \\
(1.17)\end{array}$ & & $\begin{array}{l}-0.29 \\
(4.84)\end{array}$ & $\begin{array}{c}0.12 \\
(0.94)\end{array}$ & $\begin{array}{c}0.13 \\
(1.42)\end{array}$ & $\begin{array}{l}-0.10 \\
(1.14)\end{array}$ & $\begin{array}{l}-0.14 \\
(2.16)\end{array}$ & \\
\hline$\Delta \log p_{y, t-1}$ & & & & & & & $\begin{array}{c}0.65 \\
(2.77)\end{array}$ & $\begin{array}{c}1.27 \\
(3.41)\end{array}$ & $\begin{array}{l}-0.14 \\
(1.64)\end{array}$ & & & & $\begin{array}{c}0.57 \\
(-)\end{array}$ \\
\hline$\Delta \log p_{x . t-1}^{w}$ & & & $\begin{array}{c}0.21 \\
(-)\end{array}$ & $\begin{array}{c}0.38 \\
(4.39)\end{array}$ & & & $\begin{array}{c}0.35 \\
(-)\end{array}$ & & $\begin{array}{c}0.62 \\
(-)\end{array}$ & $\begin{array}{c}0.30 \\
(2.52)\end{array}$ & $\begin{array}{c}0.10 \\
(1.52)\end{array}$ & & $\begin{array}{l}0.05 \\
(2.10)\end{array}$ \\
\hline$t$ & $\begin{array}{l}-0.002 \\
(4.16)\end{array}$ & $\begin{array}{c}-0.0002 \\
(1.69)\end{array}$ & $\begin{array}{c}-0.0002 \\
(2.94)\end{array}$ & $\begin{array}{c}-0.0006 \\
(3.05)\end{array}$ & $\begin{array}{c}-0.0003 \\
(3.52)\end{array}$ & $\begin{array}{c}-0.0004 \\
(1.78)\end{array}$ & $\begin{array}{c}-0.0001 \\
(1.33)\end{array}$ & $\begin{array}{c}-0.0003 \\
(2.25)\end{array}$ & $\begin{array}{c}-0.0003 \\
(3.09)\end{array}$ & $\begin{array}{c}-0.0006 \\
(2.25)\end{array}$ & $\begin{array}{c}-0.0003 \\
(2.17)\end{array}$ & $\begin{array}{r}-0.001 \\
(3.87)\end{array}$ & $\begin{array}{c}-0.0003 \\
(2.75)\end{array}$ \\
\hline t & 0.72 & 0.54 & 0.73 & 0.63 & 0.81 & 0.41 & 0.73 & 0.58 & 0.57 & 0.74 & 0.56 & 0.51 & 0.70 \\
\hline
\end{tabular}

Table 12 Parameter estimates of the export price deflator equations 


\section{A.14 Wages and prices: price deflator imports of goods and services}

$$
\begin{aligned}
\Delta \log p_{m, t}=\alpha & \left\{\log p_{m, t-1}-\beta_{1} \log p_{m, t-1}^{w}-\beta_{2} \log \left(\underline{p}_{o i l, t-1} e_{D O L, t-1}\right)\right. \\
& \left.-\left(1-\beta_{1}-\beta_{2}\right) \log \left(\underline{p}_{c o m, t-1} e_{D O L, t-1}\right)\right\}+\sum_{i=1}^{4} \gamma_{1, i} \Delta \log p_{m, t-i} \\
& +\gamma_{2} \Delta \log \left(\underline{p}_{\text {oil }, t-1} e_{D O L, t-1}\right)+\gamma_{3} \Delta \log \left(\underline{p}_{c o m, t-1} e_{D O L, t-1}\right)+\gamma_{4} \Delta u l c_{t-1}+\xi t
\end{aligned}
$$

with

$p_{m} \quad=$ price deflator imports of goods and services (index, 1990=100)

$p_{m}^{w} \quad=$ weighted import price (index, 1990=100)

$\underline{p}_{\text {oil }}=$ spot price Brent per barrel (in USD, index, 1990=100)

$\bar{e}_{D O L}=$ nominal exchange rate in, domestic currency per USD

$\underline{p}_{\text {com }}=$ commodity price, excluding oil (in USD, index, 1990=100)

ulc $=$ unit labour costs

$t=$ deterministic linear trend 
Table 13 Parameter estimates of the import price deflator equations

\begin{tabular}{|c|c|c|c|c|c|c|c|c|c|c|c|c|c|}
\hline & $\mathrm{AU}$ & $\mathrm{BE}$ & DE & DK & ES & FI & FR & IT & NL & SW & UK & JP & US \\
\hline$L T(\alpha)$ & $\begin{array}{l}-0.05 \\
(2.22)\end{array}$ & $\begin{array}{l}-0.08 \\
(2.75)\end{array}$ & $\begin{array}{l}-0.04 \\
(2.09)\end{array}$ & $\begin{array}{c}-0.09 \\
(3.80)\end{array}$ & $\begin{array}{c}-0.12 \\
(-)\end{array}$ & $\begin{array}{l}-0.15 \\
(3.64)\end{array}$ & $\begin{array}{c}-0.12 \\
(-)\end{array}$ & $\begin{array}{l}-0.17 \\
(2.91)\end{array}$ & $\begin{array}{c}-0.12 \\
(-)\end{array}$ & $\begin{array}{l}-0.34 \\
(3.12)\end{array}$ & $\begin{array}{l}-0.11 \\
(1.67)\end{array}$ & $\begin{array}{c}-0.12 \\
(-)\end{array}$ & $\begin{array}{l}-0.08 \\
(2.68)\end{array}$ \\
\hline $\log p_{m, t-1}^{w}$ & $\begin{array}{c}0.82 \\
(-)\end{array}$ & $\begin{array}{c}0.77 \\
(-)\end{array}$ & $\begin{array}{c}0.78 \\
(-)\end{array}$ & $\begin{array}{c}0.79 \\
(-)\end{array}$ & $\begin{array}{c}0.75 \\
(-)\end{array}$ & $\begin{array}{c}0.78 \\
(-)\end{array}$ & $\begin{array}{c}0.80 \\
(-)\end{array}$ & $\begin{array}{c}0.76 \\
(-)\end{array}$ & $\begin{array}{c}0.79 \\
(-)\end{array}$ & $\begin{array}{r}0.85 \\
(-)\end{array}$ & $\begin{array}{r}0.83 \\
(-)\end{array}$ & $\begin{array}{r}0.51 \\
(-)\end{array}$ & $\begin{array}{r}0.83 \\
(-)\end{array}$ \\
\hline $\log \left(\underline{p}_{\text {oil.t-1 }} e_{D O L, t-1}\right)$ & $\begin{array}{c}0.07 \\
(-)\end{array}$ & $\begin{array}{c}0.08 \\
(-)\end{array}$ & $\begin{array}{c}0.09 \\
(-)\end{array}$ & $\begin{array}{c}0.05 \\
(-)\end{array}$ & $\begin{array}{c}0.10 \\
(-)\end{array}$ & $\begin{array}{c}0.10 \\
(-)\end{array}$ & $\begin{array}{c}0.08 \\
(-)\end{array}$ & $\begin{array}{c}0.08 \\
(-)\end{array}$ & $\begin{array}{c}0.08 \\
(-)\end{array}$ & $\begin{array}{c}0.06 \\
(-)\end{array}$ & $\begin{array}{r}0.04 \\
(-)\end{array}$ & $\begin{array}{r}0.24 \\
(-)\end{array}$ & $\begin{array}{r}0.10 \\
(-)\end{array}$ \\
\hline $\log \left(\underline{p}_{\text {com.t }-1} e_{D O L, t-1}\right)$ & $\begin{array}{c}0.11 \\
(-)\end{array}$ & $\begin{array}{c}0.15 \\
(-)\end{array}$ & $\begin{array}{c}0.13 \\
(-)\end{array}$ & $\begin{array}{c}0.16 \\
(-)\end{array}$ & $\begin{array}{c}0.15 \\
(-)\end{array}$ & $\begin{array}{c}0.12 \\
(-)\end{array}$ & $\begin{array}{c}0.12 \\
(-)\end{array}$ & $\begin{array}{c}0.16 \\
(-)\end{array}$ & $\begin{array}{r}0.13 \\
(-)\end{array}$ & $\begin{array}{r}0.09 \\
(-)\end{array}$ & $\begin{array}{r}0.13 \\
(-)\end{array}$ & $\begin{array}{r}0.25 \\
(-)\end{array}$ & $\begin{array}{r}0.07 \\
(-)\end{array}$ \\
\hline$\Delta \log p_{m, t-1}$ & $\begin{array}{l}-0.20 \\
(2.02)\end{array}$ & $\begin{array}{c}0.22 \\
(2.70)\end{array}$ & & & & & $\begin{array}{c}0.09 \\
(0.80)\end{array}$ & $\begin{array}{c}0.37 \\
(3.22)\end{array}$ & $\begin{array}{c}0.21 \\
(1.96)\end{array}$ & & & $\begin{array}{c}0.29 \\
(2.40)\end{array}$ & $\begin{array}{l}-0.11 \\
(0.74)\end{array}$ \\
\hline$\Delta \log p_{m, t-2}$ & & $\begin{array}{c}0.15 \\
(2.09)\end{array}$ & & & & & $\begin{array}{c}0.04 \\
(0.44)\end{array}$ & & & & & $\begin{array}{l}-0.14 \\
(1.43)\end{array}$ & $\begin{array}{c}0.04 \\
(0.40)\end{array}$ \\
\hline$\Delta \log p_{m, t-3}$ & & & & & & & $\begin{array}{c}0.07 \\
(0.75)\end{array}$ & & & & & $\begin{array}{c}0.31 \\
(3.02)\end{array}$ & $\begin{array}{c}0.25 \\
(2.48)\end{array}$ \\
\hline$\Delta \log p_{m, t-4}$ & & & & & & & & & & & & $\begin{array}{l}-0.30 \\
(4.73)\end{array}$ & \\
\hline$\Delta \log \left(\underline{p}_{o i l, t-1} e_{D O L, t-1}\right)$ & $\begin{array}{c}0.04 \\
(1.97)\end{array}$ & & $\begin{array}{c}0.07 \\
(4.20)\end{array}$ & $\begin{array}{c}0.04 \\
(1.62)\end{array}$ & $\begin{array}{c}0.06 \\
(2.74)\end{array}$ & & $\begin{array}{c}0.05 \\
(2.74)\end{array}$ & & $\begin{array}{c}0.04 \\
(1.93)\end{array}$ & $\begin{array}{c}0.07 \\
(2.84)\end{array}$ & & $\begin{array}{c}0.14 \\
(2.73)\end{array}$ & $\begin{array}{c}0.08 \\
(5.14)\end{array}$ \\
\hline$\Delta \log \left(\underline{p}_{c o m, t-1} e_{D O L . t-1}\right)$ & $\begin{array}{c}0.07 \\
(1.73)\end{array}$ & & $\begin{array}{c}0.10 \\
(3.57)\end{array}$ & $\begin{array}{c}0.15 \\
(5.14)\end{array}$ & $\begin{array}{c}0.20 \\
(3.43)\end{array}$ & & $\begin{array}{c}0.10 \\
(2.99)\end{array}$ & $\begin{array}{c}0.12 \\
(2.94)\end{array}$ & $\begin{array}{c}0.09 \\
(2.34)\end{array}$ & & $\begin{array}{c}0.12 \\
(2.97)\end{array}$ & & $\begin{array}{c}0.14 \\
(2.79)\end{array}$ \\
\hline$\Delta u l c_{t-1}$ & & & & & & & $\begin{array}{c}0.69 \\
(5.23)\end{array}$ & $\begin{array}{c}0.44 \\
(3.09)\end{array}$ & $\begin{array}{c}0.03 \\
(3.06)\end{array}$ & & $\begin{array}{c}0.46 \\
(2.48)\end{array}$ & & \\
\hline$t$ & & & & & & & & & & & & & $\begin{array}{c}-0.0003 \\
(3.53)\end{array}$ \\
\hline $\bar{R}^{2}$ & 0.12 & 0.63 & 0.49 & 0.43 & 0.34 & 0.19 & 0.56 & 0.54 & 0.47 & 0.31 & 0.21 & 0.50 & 0.65 \\
\hline
\end{tabular}




\section{A.15 Public sector: transfers from public sector to private sector}

$$
\begin{aligned}
\frac{T R_{t}}{Y_{t}}= & \gamma_{1} \frac{T R_{t-1}}{Y_{t-1}}+\gamma_{2}\left(u_{t}-\gamma_{1} u_{t-1}\right) \\
& +\gamma_{3} \log \frac{\underline{d u m} w_{g, t-1}+(1-\underline{d u m}) p_{c, t-1}}{p_{y, t-1}}
\end{aligned}
$$

with

$T R=$ transfers from public sector to private sector

$Y=$ gross domestic product in nominal terms

$u=$ unemployment rate (in \%)

$\underline{d u m}=1$ for AU, DE, DK, ES, FI, FR, IT, NL, UK

$=0$ for $\mathrm{BE}, \mathrm{SW}, \mathrm{JP}, \mathrm{US}$

$w_{g}=$ government wage rate (per employee)

$p_{c}=$ price deflator private consumption (index, 1990=100)

$p_{y} \quad=$ price deflator gross domestic product (index, 1990=100) 
Table 14 Parameter estimates of the transfers equations

\begin{tabular}{|c|c|c|c|c|c|c|c|c|c|c|c|c|c|}
\hline & $\mathrm{AU}$ & $\mathrm{BE}$ & $\mathrm{DE}$ & DK & ES & FI & FR & IT & $\mathrm{NL}$ & SW & UK & JP & US \\
\hline$\frac{T R_{t-1}}{Y_{t-1}}$ & $\begin{array}{c}0.86 \\
(15.2)\end{array}$ & $\begin{array}{c}0.95 \\
(26.5)\end{array}$ & $\begin{array}{l}0.79 \\
(26.0)\end{array}$ & $\begin{array}{c}0.89 \\
(21.4)\end{array}$ & $\begin{array}{l}0.97 \\
(52.1)\end{array}$ & $\begin{array}{c}0.93 \\
(30.6)\end{array}$ & $\begin{array}{l}0.87 \\
(16.8)\end{array}$ & $\begin{array}{l}0.94 \\
(21.6)\end{array}$ & $\begin{array}{l}0.91 \\
(28.4)\end{array}$ & $\begin{array}{l}0.94 \\
(39.0)\end{array}$ & $\begin{array}{l}0.95 \\
(26.6)\end{array}$ & $\begin{array}{l}0.37 \\
(5.34)\end{array}$ & $\begin{array}{l}0.76 \\
(13.3)\end{array}$ \\
\hline$u_{t}-\gamma_{1} u_{t-1}$ & $\begin{array}{l}0.005 \\
(3.80)\end{array}$ & $\begin{array}{l}0.006 \\
(3.80)\end{array}$ & $\begin{array}{l}0.003 \\
(3.34)\end{array}$ & $\begin{array}{c}0.01 \\
(7.31)\end{array}$ & $\begin{array}{l}0.002 \\
(1.99)\end{array}$ & & $\begin{array}{l}0.005 \\
(2.80)\end{array}$ & & $\begin{array}{l}0.005 \\
(2.24)\end{array}$ & $\begin{array}{l}0.01 \\
(3.49)\end{array}$ & $\begin{array}{l}0.004 \\
(5.38)\end{array}$ & & $\begin{array}{l}0.005 \\
(7.14)\end{array}$ \\
\hline $\begin{array}{l}u_{t}-\frac{1}{8} \sum_{i=0}^{7} u_{t-i} \\
\quad-\gamma_{1}\left(u_{t-1}-\frac{1}{8} \sum_{i=0}^{7} u_{t-1-i}\right)\end{array}$ & & & & & & $\begin{array}{l}0.001 \\
(1.18)\end{array}$ & & & & & & $\begin{array}{c}0.01 \\
(1.27)\end{array}$ & \\
\hline $\begin{array}{l}u_{t-1}-\frac{1}{8} \sum_{i=0}^{7} u_{t-1}-i \\
\quad-\gamma_{1}\left(u_{t-2}-\frac{1}{8} \sum_{i=0}^{7} u_{t-2-i}\right)\end{array}$ & & & & & & & & $\begin{array}{l}0.004 \\
(1.94)\end{array}$ & & & & & \\
\hline $\log \frac{w_{g . t}}{p_{y, t}}$ & $\begin{array}{c}0.18 \\
(10.14)\end{array}$ & & & & $\begin{array}{c}0.05 \\
(3.61)\end{array}$ & & & $\begin{array}{c}0.09 \\
(2.68)\end{array}$ & $\begin{array}{l}0.08 \\
(9.22)\end{array}$ & & $\begin{array}{l}0.02 \\
(2.25)\end{array}$ & & \\
\hline $\log \frac{w_{g, t-1}}{p_{y, t-1}}$ & $\begin{array}{l}-0.15 \\
(7.25)\end{array}$ & & $\begin{array}{c}0.06 \\
(4.50)\end{array}$ & $\begin{array}{c}0.04 \\
(2.70)\end{array}$ & $\begin{array}{l}-0.05 \\
(2.82)\end{array}$ & $\begin{array}{l}0.02 \\
(2.00)\end{array}$ & $\begin{array}{l}0.03 \\
(1.29)\end{array}$ & $\begin{array}{l}-0.08 \\
(2.17)\end{array}$ & $\begin{array}{l}-0.05 \\
(6.86)\end{array}$ & & $\begin{array}{l}-0.02 \\
(1.97)\end{array}$ & & \\
\hline $\log \frac{w_{g, t-2}}{p_{y, t-2}}$ & & & & & & $\begin{array}{l}-0.01 \\
(0.73)\end{array}$ & $\begin{array}{l}-0.02 \\
(0.72)\end{array}$ & & & & & & \\
\hline $\log \frac{p_{c, t}}{p_{y, t}}$ & & & & & & & & & & $\begin{array}{c}0.09 \\
(10.3)\end{array}$ & & $\begin{array}{c}0.34 \\
(11.3)\end{array}$ & $\begin{array}{c}0.17 \\
(4.33)\end{array}$ \\
\hline $\log \frac{p_{c, t-1}}{p_{y, t-1}}$ & & $\begin{array}{c}0.10 \\
(-)\end{array}$ & & & & & & & & $\begin{array}{l}-0.07 \\
(7.76)\end{array}$ & & & \\
\hline $\log \frac{p_{c, t-2}}{p_{y, t}-2}$ & & $\begin{array}{c}-0.10 \\
(-)\end{array}$ & & & & & & & & & & & \\
\hline $\bar{R}^{2}$ & 0.99 & 0.99 & 0.94 & 0.98 & 0.99 & 0.98 & 0.99 & 0.99 & 0.96 & 0.98 & 0.99 & 0.76 & 0.93 \\
\hline
\end{tabular}




\section{A.16 Monetary and financial sector: nominal long-term interest rate}

$$
\begin{aligned}
\Delta r_{l, t}-\Delta r_{l, t}^{D E}=\alpha & \left\{r_{l, t-1}-r_{l, t-1}^{D E}-\beta_{1}\left(r_{s, t-1}-\dot{p}_{c, t-1}-r_{s, t-1}^{D E}+\dot{p}_{c, t-1}^{D E}\right)\right. \\
& \left.-\beta_{2}\left(\dot{p}_{c, t-1}-\dot{p}_{c, t-1}^{D E}\right)-\beta_{3}\left(G F B Y_{t-1}-G F B Y_{t-1}^{D E}\right)\right\} \\
+ & \sum_{i=1}^{4} \gamma_{1, i}\left(\Delta r_{l, t-i}-\Delta r_{l, t-i}^{D E}\right)+\gamma_{2}\left(\Delta r_{s, t}-\Delta \dot{p}_{c, t}-\Delta r_{s, t}^{D E}+\Delta \dot{p}_{c, t}^{D E}\right) \\
+ & \gamma_{3}\left(\Delta \dot{p}_{c, t}-\Delta \dot{p}_{c, t}^{D E}\right)+\gamma_{4}\left(\Delta G F B Y_{t}-\Delta G F B Y_{t}^{D E}\right) \\
& +\gamma_{5}\left(\Delta_{4} G F B Y_{t}-\Delta_{4} G F B Y_{t}^{D E}\right)
\end{aligned}
$$

for AU, BE, DK, ES, FI, FR, IT, NL, SW covering the sample period 1991Q1-1998Q4 and

$$
\begin{aligned}
\Delta r_{l, t}= & \alpha\left\{r_{l, t-1}-\beta_{1} r_{l, t-1}^{U S}-\beta_{2}\left(r_{s, t-1}-\dot{p}_{c, t-1}\right)-\beta_{3} \dot{p}_{c, t-1}-\beta_{4} G F B Y_{t-1}\right\} \\
& +\gamma_{1} \Delta r_{l, t}^{U S}+\sum_{i=0}^{1} \gamma_{2} \Delta r_{l, t-i}^{D E}+\gamma_{3}\left(\Delta r_{s, t-1}-\Delta \dot{p}_{c, t-1}\right)+\gamma_{4} \Delta \dot{p}_{c, t-1}
\end{aligned}
$$

for DE, UK, JP and US covering the sample period 1980Q1-1998Q4 with

$$
\begin{array}{ll}
r_{l} & =\text { nominal long-term interest rate (in \%) } \\
r_{s} & =\text { nominal short-term interest rate (in \%) } \\
\dot{p}_{c} & =\text { inflation (in \%) } \\
G F B Y & =\text { government financial balance ratio (\% GDP) }
\end{array}
$$


Table 15 Parameter estimates of long-term interest rate equations

\begin{tabular}{|c|c|c|c|c|c|c|c|c|c|c|c|c|c|}
\hline & $\mathrm{AU}$ & $\mathrm{BE}$ & $\mathrm{DE}$ & DK & ES & FI & FR & IT & NL & SW & UK & JP & US \\
\hline$L T(\alpha)$ & $\begin{array}{l}-0.61 \\
(6.72)\end{array}$ & $\begin{array}{l}-0.33 \\
(2.24)\end{array}$ & $\begin{array}{l}-0.13 \\
(3.47)\end{array}$ & $\begin{array}{l}-0.64 \\
(3.24)\end{array}$ & $\underset{(-)}{-0.20}$ & $\begin{array}{l}-0.11 \\
(3.24)\end{array}$ & $\begin{array}{l}-0.14 \\
(1.86)\end{array}$ & $\begin{array}{c}-0.20 \\
(-)\end{array}$ & $\begin{array}{l}-0.26 \\
(2.32)\end{array}$ & $\begin{array}{l}-0.39 \\
(2.75)\end{array}$ & $\begin{array}{l}-0.11 \\
(3.38)\end{array}$ & $\begin{array}{l}-0.09 \\
(1.96)\end{array}$ & $\begin{array}{l}-0.16 \\
(3.03)\end{array}$ \\
\hline$r_{l, t-1}^{U S}$ & & & $\begin{array}{c}0.20 \\
(2.05)\end{array}$ & & & & & & & & & $\begin{array}{c}0.35 \\
(1.35)\end{array}$ & \\
\hline$r_{s, t-1}-\dot{p}_{c, t-1}$ & & & & & & & & & & & & & \\
\hline$-r_{s, t-1}^{D E}+\dot{p}_{c, t-1}^{D E}$ & $\begin{array}{c}0.48 \\
(3.49)\end{array}$ & $\begin{array}{c}0.35 \\
(1.20)\end{array}$ & & $\begin{array}{c}0.09 \\
(3.36)\end{array}$ & $\begin{array}{l}0.56 \\
(5.84)\end{array}$ & $\begin{array}{c}0.80 \\
(-)\end{array}$ & $\begin{array}{l}0.12 \\
(5.60)\end{array}$ & $\begin{array}{c}0.71 \\
(1.02)\end{array}$ & $\begin{array}{l}0.87 \\
(2.15)\end{array}$ & $\begin{array}{l}0.20 \\
(2.59)\end{array}$ & & & \\
\hline$r_{s, t-1}-\dot{p}_{c, t-1}$ & & & $\begin{array}{c}0.09 \\
(0.56)\end{array}$ & & & & & & & & $\begin{array}{c}0.33 \\
(3.00)\end{array}$ & $\begin{array}{l}0.42 \\
(1.14)\end{array}$ & $\begin{array}{c}0.68 \\
(5.62)\end{array}$ \\
\hline$\dot{p}_{c . t-1}-\dot{p}_{c . t-1}^{D E}$ & $\begin{array}{c}0.30 \\
(2.33)\end{array}$ & $\begin{array}{l}0.37 \\
(1.40)\end{array}$ & & $\begin{array}{c}0.12 \\
(2.37)\end{array}$ & $\begin{array}{l}0.72 \\
(6.20)\end{array}$ & $\begin{array}{c}0.80 \\
(-)\end{array}$ & $\begin{array}{c}0.12 \\
(-)\end{array}$ & $\begin{array}{l}0.81 \\
(2.89)\end{array}$ & $\begin{array}{l}0.72 \\
(1.86)\end{array}$ & $\begin{array}{l}0.15 \\
(1.27)\end{array}$ & & & \\
\hline$\dot{p}_{c . t-1}$ & & & $\begin{array}{c}0.48 \\
(4.09)\end{array}$ & & & & & & & & $\begin{array}{l}0.72 \\
(7.06)\end{array}$ & $\begin{array}{l}0.52 \\
(2.88)\end{array}$ & $\begin{array}{l}0.96 \\
(7.67)\end{array}$ \\
\hline$\frac{1}{4} \sum_{i=1}^{4} G F B Y_{t-i}$ & & & & & & & & & & & $\begin{array}{l}-0.25 \\
(3.14)\end{array}$ & & $\begin{array}{l}-0.45 \\
(2.50)\end{array}$ \\
\hline$G F B Y_{t-1}-G F B Y_{t-1}^{D E}$ & $\begin{array}{l}-0.09 \\
(5.36)\end{array}$ & $\begin{array}{l}-0.13 \\
(1.66)\end{array}$ & & & & & $\begin{array}{l}-0.19 \\
(2.05)\end{array}$ & & & & & & \\
\hline$\frac{1}{4} \sum_{i=1}^{4} G F B Y_{t-i}-G F B Y_{t-i}^{D E}$ & & & & $\begin{array}{c}-0.10 \\
(-)\end{array}$ & $\begin{array}{l}-0.32 \\
(1.12)\end{array}$ & $\begin{array}{l}-0.43 \\
(3.04)\end{array}$ & & $\begin{array}{l}-0.79 \\
(2.01)\end{array}$ & $\begin{array}{c}-0.10 \\
(-)\end{array}$ & $\begin{array}{l}-0.23 \\
(2.26)\end{array}$ & & & \\
\hline$\Delta r_{l . t-1}-\Delta r_{l, t-1}^{D E}$ & $\begin{array}{l}-0.24 \\
(3.02)\end{array}$ & & & $\begin{array}{c}0.40 \\
(3.03)\end{array}$ & & & & & & & & & \\
\hline$\Delta r_{l, t-4}-\Delta r_{l, t-4}^{D E}$ & & & & & & $\begin{array}{l}-0.49 \\
(2.77)\end{array}$ & & & & & & & \\
\hline$\Delta r_{l . t}^{U S}$ & & & $\begin{array}{c}0.32 \\
(6.20)\end{array}$ & & & & & & & & $\begin{array}{c}0.17 \\
(2.02)\end{array}$ & $\begin{array}{c}0.29 \\
(3.97)\end{array}$ & \\
\hline$\Delta r_{l . t}^{D E}$ & & & & & & & & & & & $\begin{array}{c}0.42 \\
(2.21)\end{array}$ & & \\
\hline$\Delta r_{l, t-1}^{D E}$ & & & $\begin{array}{c}0.29 \\
(4.42)\end{array}$ & & & & & & & & & & \\
\hline$\Delta r_{s . t}-\Delta \dot{p}_{c, t}$ & & & & & & & & & & & & & \\
\hline$-\Delta r_{s, t}^{D E}+\Delta \dot{p}_{c, t}^{D E}$ & $\begin{array}{c}0.46 \\
(3.63)\end{array}$ & $\begin{array}{c}0.11 \\
(3.07)\end{array}$ & & $\begin{array}{c}0.09 \\
(-)\end{array}$ & $\begin{array}{c}0.56 \\
(-)\end{array}$ & $\begin{array}{c}0.80 \\
(-)\end{array}$ & $\begin{array}{c}0.12 \\
(-)\end{array}$ & $\begin{array}{l}0.23 \\
(1.74)\end{array}$ & $\begin{array}{l}0.37 \\
(2.93)\end{array}$ & $\begin{array}{l}0.05 \\
(4.58)\end{array}$ & & & \\
\hline$\Delta r_{s . t}-\Delta \dot{p}_{c, t}$ & & & $\begin{array}{l}0.18 \\
(3.53)\end{array}$ & & & & & & & & $\begin{array}{l}0.34 \\
(7.76)\end{array}$ & $\begin{array}{l}0.23 \\
(2.92)\end{array}$ & $\begin{array}{l}0.35 \\
(8.10)\end{array}$ \\
\hline$\Delta \dot{p}_{c, t}-\Delta \dot{p}_{c, t}^{D E}$ & $\begin{array}{c}0.43 \\
(3.28)\end{array}$ & $\begin{array}{c}0.11 \\
(3.07)\end{array}$ & & $\begin{array}{c}0.12 \\
(-)\end{array}$ & $\begin{array}{c}0.72 \\
(-)\end{array}$ & $\begin{array}{c}0.80 \\
(-)\end{array}$ & $\begin{array}{c}0.12 \\
(-)\end{array}$ & $\begin{array}{l}0.17 \\
(1.35)\end{array}$ & $\begin{array}{l}0.38 \\
(3.32)\end{array}$ & $\begin{array}{c}0.05 \\
(-)\end{array}$ & & & \\
\hline$\Delta \dot{p}_{c, t}$ & & & $\begin{array}{l}0.20 \\
(3.46)\end{array}$ & & & & & & & & $\begin{array}{l}0.41 \\
(6.79)\end{array}$ & $\begin{array}{l}0.23 \\
(3.40)\end{array}$ & $\begin{array}{l}0.32 \\
(3.21)\end{array}$ \\
\hline$\frac{1}{4} \sum_{i=0}^{3} \Delta G F B Y_{t-i}$ & & & $\begin{array}{l}-0.08 \\
(0.63)\end{array}$ & & & & & & & & $\begin{array}{l}-0.25 \\
(3.14)\end{array}$ & & \\
\hline$\triangle G F B Y_{t}-\triangle G F B Y_{t}^{D E}$ & $\begin{array}{l}-0.08 \\
(2.00)\end{array}$ & $\begin{array}{l}-0.13 \\
(1.56)\end{array}$ & & & & & $\begin{array}{c}-0.19 \\
(-)\end{array}$ & & & & & & \\
\hline$\Delta_{4} G F B Y_{t}-\Delta_{4} G F B Y_{t}^{D E}$ & & & & & $\begin{array}{l}-0.32 \\
(1.12)\end{array}$ & $\begin{array}{c}-0.43 \\
(-)\end{array}$ & & $\begin{array}{c}-0.89 \\
(-)\end{array}$ & & $\begin{array}{l}-0.04 \\
(0.31)\end{array}$ & & & \\
\hline$\underline{\bar{R}^{2}}$ & 0.85 & 0.28 & 0.54 & 0.54 & 0.65 & 0.47 & 0.62 & 0.79 & 0.28 & 0.27 & 0.58 & 0.23 & 0.51 \\
\hline
\end{tabular}




\section{A.17 Monetary and financial sector: broad money}

$$
\begin{aligned}
& \Delta \log \left(\frac{\mathrm{M} 3_{t}}{\underline{\text { dum }} p_{c, t}+(1-\underline{\text { dum }}) p_{y, t}}\right)=
\end{aligned}
$$

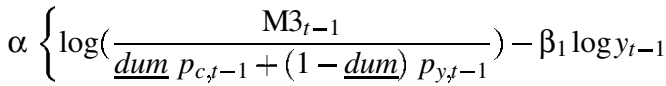

$$
\begin{aligned}
& -\left(1-\beta_{1}\right) \log \left(\frac{N F W_{t-1}+E_{M V, t-1}}{\underline{\text { dum } p_{c, t-1}+(1-\underline{d u m}) p_{y, t-1}}}\right)-\beta_{2} r_{s, t-1} \\
& \left.-\beta_{3} r_{l, t-1}-\beta_{4}\left(\underline{d u m} \dot{p}_{c, t-1}+(1-\underline{d u m}) \Delta_{4} p_{y, t-1}\right)\right\} \\
& +\sum_{i=1}^{4} \gamma_{1, i} \Delta \log \left(\frac{\mathrm{M} 3_{t-i}}{\underline{\underline{d u m}} p_{c, t-i}+(1-\underline{d u m}) p_{y, t-i}}\right)+\sum_{i=1}^{4} \gamma_{2, i} \Delta \log y_{t-i} \\
& +\sum_{i=1}^{4} \gamma_{3, i} \Delta \log \left(\frac{N F W_{t-i}+E_{M V, t-i}}{\underline{d u m} p_{c, t-i}+(1-\underline{d u m}) p_{y, t-i}}\right)+\sum_{i=1}^{4} \gamma_{4, i} \Delta r_{s, t-i} \\
& +\sum_{i=1}^{4} \gamma_{5, i} \Delta r_{l, t-i}+\sum_{i=1}^{4} \gamma_{6, i} \Delta \dot{p}_{c, t-i}+\sum_{i=0}^{3} \gamma_{7, i} \operatorname{gap}_{t-i}
\end{aligned}
$$

with

M3 = broad money

$p_{c} \quad=$ price deflator private consumption (index, 1990=100)

$p_{y} \quad=$ price deflator gross domestic product (index, 1990=100)

$\underline{d u m}=1$ for AU, BE, DE, DK, ES, IT, NL, SW, JP, US

$=0$ for FI, FR, UK

$y=$ gross domestic product in real terms

$N F W=$ net financial wealth private sector

$E_{M V}=$ market value domestic equity

$r_{s}=$ nominal short-term interest rate (in \%)

$r_{l}=$ nominal long-term interest rate (in \%)

$\dot{p}_{c} \quad=$ inflation (in \%)

gap $=$ output gap (in \%) 
Table 16 Parameter estimates of the broad money equations

\begin{tabular}{|c|c|c|c|c|c|c|c|c|c|c|c|c|c|}
\hline & $\mathrm{AU}$ & $\mathrm{BE}$ & $\mathrm{DE}$ & DK & ES & FI & FR & IT & $\mathrm{NL}$ & SW & UK & JP & US \\
\hline$L T(\alpha)$ & $\begin{array}{l}-0.12 \\
(3.17)\end{array}$ & $\begin{array}{l}-0.18 \\
(5.06)\end{array}$ & $\begin{array}{l}-0.15 \\
(3.68)\end{array}$ & $\begin{array}{l}-0.24 \\
(7.00)\end{array}$ & $\begin{array}{l}-0.02 \\
(0.87)\end{array}$ & $\begin{array}{c}-0.08 \\
(4.35)\end{array}$ & $\begin{array}{l}-0.09 \\
(2.31)\end{array}$ & $\begin{array}{c}-0.03 \\
(-)\end{array}$ & $\begin{array}{l}-0.10 \\
(2.96)\end{array}$ & $\begin{array}{c}-0.02 \\
(-)\end{array}$ & $\begin{array}{l}-0.02 \\
(2.60)\end{array}$ & $\begin{array}{l}-0.09 \\
(6.24)\end{array}$ & $\begin{array}{c}-0.02 \\
(2.17)\end{array}$ \\
\hline $\log y_{t-1}$ & $\begin{array}{c}0.83 \\
(24.77)\end{array}$ & $\begin{array}{c}0.86 \\
(36.64)\end{array}$ & $\begin{array}{c}0.77 \\
(25.96)\end{array}$ & $\begin{array}{c}0.99 \\
(64.40)\end{array}$ & $\begin{array}{c}0.93 \\
(7.15)\end{array}$ & $\begin{array}{l}1.00 \\
(-)\end{array}$ & $\begin{array}{l}1.00 \\
(-)\end{array}$ & $\begin{array}{l}1.00 \\
(-)\end{array}$ & $\begin{array}{c}0.62 \\
(18.28)\end{array}$ & $\begin{array}{l}1.00 \\
(-)\end{array}$ & $\begin{array}{c}0.71 \\
(2.48)\end{array}$ & $\begin{array}{c}0.84 \\
(25.60)\end{array}$ & $\begin{array}{c}0.88 \\
(3.53)\end{array}$ \\
\hline $\log \frac{N F W_{t-1}+E_{M V . t-1}}{p_{c . t-1}}$ & $\begin{array}{l}0.17 \\
(-)\end{array}$ & $\begin{array}{l}0.14 \\
(-)\end{array}$ & $\begin{array}{l}0.23 \\
(-)\end{array}$ & $\begin{array}{l}0.01 \\
(-)\end{array}$ & $\begin{array}{l}0.07 \\
(-)\end{array}$ & & & & $\begin{array}{c}0.38 \\
(-)\end{array}$ & & & $\begin{array}{l}0.16 \\
(-)\end{array}$ & $\begin{array}{l}0.12 \\
(-)\end{array}$ \\
\hline $\log \frac{N F W_{t-1}+E_{M V . t-1}}{p_{y, t-1}}$ & & & & & & & & & & & $\begin{array}{l}0.29 \\
(-)\end{array}$ & & \\
\hline$r_{s, t-1}$ & $\begin{array}{c}0.01 \\
(1.04)\end{array}$ & & $\begin{array}{c}0.01 \\
(2.31)\end{array}$ & $\begin{array}{c}0.02 \\
(3.16)\end{array}$ & $\begin{array}{l}0.02 \\
(-)\end{array}$ & & & & $\begin{array}{c}0.01 \\
(1.05)\end{array}$ & & $\begin{array}{c}0.02 \\
(1.04)\end{array}$ & $\begin{array}{c}0.02 \\
(3.21)\end{array}$ & $\begin{array}{c}0.04 \\
(1.60)\end{array}$ \\
\hline$r_{l, t-1}$ & $\begin{array}{l}-0.01 \\
(0.59)\end{array}$ & $\begin{array}{l}-0.03 \\
(5.50)\end{array}$ & $\begin{array}{l}-0.05 \\
(3.71)\end{array}$ & $\begin{array}{l}-0.03 \\
(5.77)\end{array}$ & $\begin{array}{c}-0.01 \\
(-)\end{array}$ & & $\begin{array}{l}-0.01 \\
(1.26)\end{array}$ & $\begin{array}{c}-0.01 \\
(-)\end{array}$ & & & & $\begin{array}{c}-0.05 \\
(4.99)\end{array}$ & \\
\hline$\dot{p}_{c, t-1}$ & & & & $\begin{array}{l}-0.03 \\
(4.94)\end{array}$ & $\begin{array}{c}-0.01 \\
(-)\end{array}$ & & & $\begin{array}{c}-0.01 \\
(-)\end{array}$ & & & & & \\
\hline$\Delta_{4} p_{y . t-1}$ & & & & & & $\begin{array}{l}-0.02 \\
(1.52)\end{array}$ & & & & & & & \\
\hline$\Delta \log \frac{\mathrm{M} 3}{t-1} p_{c, t-1}$ & & & & & & & & & & $\begin{array}{c}-0.31 \\
(3.95)\end{array}$ & & & $\begin{array}{c}0.74 \\
(13.24)\end{array}$ \\
\hline$\Delta \log \frac{\mathrm{M}{ }_{t-2}}{p_{c, t-2}}$ & & & & & & & & & & & & $\begin{array}{c}0.41 \\
(6.48)\end{array}$ & \\
\hline$\Delta \log \frac{\mathrm{M}_{3}{ }_{t-2}}{p_{y, t-2}}$ & & & & & & & $\begin{array}{c}0.21 \\
(2.17)\end{array}$ & & & & & & \\
\hline$\Delta \log \frac{\mathrm{M}_{3} t-3}{p_{c, t-3}}$ & $\begin{array}{l}-0.36 \\
(4.72)\end{array}$ & $\begin{array}{c}-0.23 \\
(3.19)\end{array}$ & & $\begin{array}{l}-0.41 \\
(7.02)\end{array}$ & $\begin{array}{c}0.08 \\
(1.77)\end{array}$ & & & & & & & & \\
\hline$\Delta \log \frac{\mathrm{M}_{3-4}}{p_{c, t-4}}$ & $\begin{array}{c}0.60 \\
(9.66)\end{array}$ & & & $\begin{array}{c}0.37 \\
(5.17)\end{array}$ & $\begin{array}{c}0.21 \\
(1.53)\end{array}$ & & & $\begin{array}{c}0.97 \\
(27.72)\end{array}$ & $\begin{array}{c}0.30 \\
(3.47)\end{array}$ & $\begin{array}{c}0.24 \\
(3.22)\end{array}$ & & & \\
\hline$\Delta \log \frac{\mathrm{M}_{3} t-4}{p_{y, t-4}}$ & & & & & & $\begin{array}{c}0.60 \\
(6.99)\end{array}$ & & & & & & & \\
\hline$\Delta \log y_{t-1}$ & $\begin{array}{l}0.14 \\
(3.49)\end{array}$ & $\begin{array}{c}0.54 \\
(4.42)\end{array}$ & & & & & & & & & & $\begin{array}{c}0.44 \\
(3.61)\end{array}$ & \\
\hline$\Delta \log y_{t-2}$ & & & & & & $\begin{array}{c}0.09 \\
(3.34)\end{array}$ & & & $\begin{array}{c}0.21 \\
(1.82)\end{array}$ & & & & $\begin{array}{c}0.18 \\
(2.52)\end{array}$ \\
\hline$\Delta \log y_{t-4}$ & & & & & & & & & & & $\begin{array}{c}0.93 \\
(6.35)\end{array}$ & & \\
\hline$\Delta \log \frac{N F W_{t-4}+E_{M V . t-4}}{p_{c, t-4}}$ & & & $\begin{array}{c}0.14 \\
(2.07)\end{array}$ & & & & & & & & & & \\
\hline$\Delta \log \frac{N F W_{t-4}+E_{M V . t-4}}{p_{y . t-4}}$ & & & & & & & & & & & $\begin{array}{c}0.02 \\
(1.52)\end{array}$ & & \\
\hline$\Delta r_{s . t-2}$ & & & & & & & & & & & $\begin{array}{l}0.002 \\
(1.94)\end{array}$ & & \\
\hline$\Delta r_{s, t-3}$ & & & & $\begin{array}{l}0.002 \\
(1.92)\end{array}$ & & & & & & & & & \\
\hline$\Delta r_{s . t-4}$ & & & & $\begin{array}{l}0.01 \\
(2.98)\end{array}$ & & & & $\begin{array}{c}0.01 \\
(4.55)\end{array}$ & & $\begin{array}{l}0.003 \\
(1.52)\end{array}$ & & & \\
\hline$\Delta r_{l . t-1}$ & & & & & & & & $\begin{array}{l}-0.01 \\
(2.78)\end{array}$ & $\begin{array}{l}-0.004 \\
(1.49)\end{array}$ & & & & $\begin{array}{l}-0.003 \\
(3.37)\end{array}$ \\
\hline${ }^{\Delta} r_{l . t-2}$ & & & & $\begin{array}{l}-0.01 \\
(2.97)\end{array}$ & & $\begin{array}{l}-0.004 \\
(3.51)\end{array}$ & & & & $\begin{array}{l}-0.01 \\
(3.58)\end{array}$ & $\begin{array}{l}-0.004 \\
(1.56)\end{array}$ & & \\
\hline$\Delta \dot{p}_{c . t-1}$ & & & & & & & & $\begin{array}{l}-0.01 \\
(2.37)\end{array}$ & & & & & \\
\hline$\Delta \dot{p}_{c . t-2}$ & & & & & $\begin{array}{l}-0.004 \\
(1.71)\end{array}$ & & & & & & & & \\
\hline$\Delta \dot{p}_{c . t-4}$ & & & & & & & & & $\begin{array}{l}-0.002 \\
(1.38)\end{array}$ & & & & \\
\hline gap $_{t}$ & & $\begin{array}{l}-0.003 \\
(2.53)\end{array}$ & & & & $\begin{array}{l}-0.001 \\
(2.19)\end{array}$ & & $\begin{array}{l}-0.001 \\
(0.72)\end{array}$ & $\begin{array}{l}-0.001 \\
(0.76)\end{array}$ & & & & \\
\hline $\operatorname{gap}_{t-1}$ & $\begin{array}{l}-0.003 \\
(4.41)\end{array}$ & & $\begin{array}{l}-0.003 \\
(4.50)\end{array}$ & & & $\begin{array}{l}-0.001 \\
(2.19)\end{array}$ & & $\begin{array}{l}-0.001 \\
(0.72)\end{array}$ & $\begin{array}{l}-0.001 \\
(0.76)\end{array}$ & & & $\begin{array}{l}-0.002 \\
(3.72)\end{array}$ & $\begin{array}{l}-0.001 \\
(2.23)\end{array}$ \\
\hline $\operatorname{gap}_{t-2}$ & & & & & & $\begin{array}{l}-0.001 \\
(2.19)\end{array}$ & & $\begin{array}{l}-0.001 \\
(0.72)\end{array}$ & $\begin{array}{l}-0.001 \\
(0.76)\end{array}$ & & & & \\
\hline $\operatorname{gap}_{t-3}$ & & & & & & $\begin{array}{l}-0.001 \\
(2.19)\end{array}$ & & $\begin{array}{l}-0.001 \\
(0.72)\end{array}$ & $\begin{array}{l}-0.001 \\
(0.76)\end{array}$ & & & & \\
\hline$\underline{\bar{R}^{2}}$ & 0.75 & 0.49 & 0.70 & 0.67 & 0.85 & 0.75 & 0.37 & 0.86 & 0.57 & 0.87 & 0.53 & 0.86 & 0.69 \\
\hline
\end{tabular}




\section{A.18 Monetary and financial sector: bank credit to the private sector}

$$
\begin{aligned}
\Delta \log C R D_{t}=\alpha & \log C R D_{t-1}-\log \left(P D I_{t-1}-O I_{t-1}+C F_{t-1}-T_{d i r b, t-1}\right) \\
& +\log \left\{\frac { 1 } { 1 6 0 0 } \sum _ { i = 1 } ^ { 4 } \left(\left\{\underline{\omega}_{C R D B} \underline{\vartheta}_{C R D B}+\left(1-\underline{\omega}_{C R D B}\right) \underline{\vartheta}_{C R D H}\right\} r_{l, t-i}\right.\right. \\
& \left.\left.\left.+\left\{\underline{\omega}_{C R D B}\left(1-\underline{\vartheta}_{C R D B}\right)+\left(1-\underline{\omega}_{C R D B}\right)\left(1-\underline{\vartheta}_{C R D H}\right)\right\} r_{s, t-i}\right)\right\}\right\} \\
+ & \sum_{i=1}^{4} \gamma_{1, i} \Delta \log C R D_{t-i} \\
+ & \sum_{i=0}^{3} \gamma_{2, i}\left(\frac{1}{1600} \sum_{j=1}^{4}\left\{\underline{\omega}_{C R D B} \underline{\vartheta}_{C R D B}+\left(1-\underline{\omega}_{C R D B}\right) \underline{\vartheta}_{C R D H}\right\} \Delta r_{l, t-i-j}\right. \\
& \left.+\left\{\underline{\omega}_{C R D B}\left(1-\underline{\vartheta}_{C R D B}\right)+\left(1-\underline{\omega}_{C R D B}\right)\left(1-\underline{\vartheta}_{C R D H}\right)\right\} \Delta r_{s, t-i-j}\right) \\
& +\sum_{i=0}^{4} \gamma_{3, i} \Delta \log p_{y, t-i}\left(i_{b, t-i}+i_{h, t-i}\right)+\xi t \\
& +\sum_{i=0}^{3} \gamma_{4, i} \Delta \log \left(P D I_{t-i}-O I_{t-i}+C F_{t-i}-T_{d i r b, t-i}\right)+\sum_{i=0}^{4} \gamma_{5, i} \frac{\Delta\left(p_{y, t-i} v_{t-i}\right)}{100 Y_{t-i}}
\end{aligned}
$$

with

$C R D=$ bank credit to private sector

$P D I=$ personal disposable income

OI $=$ other household income

CF $=$ cash flow

$T_{\text {dirb }}=$ corporate taxes

$\underline{\omega}_{C R D B}=$ share bank credit businesses in total bank credit to private sector

$\underline{\vartheta}_{C R D B}=$ share long-term credit in total bank credit to businesses

$\underline{\vartheta}_{C R D H}=$ share long-term credit in total bank credit to households

$r_{l}=$ nominal long-term interest rate (in \%)

$r_{s} \quad=$ nominal short-term interest rate (in \%)

$p_{y} \quad=$ price deflator gross domestic product (index, 1990=100)

$i_{b} \quad=$ business investment (excluding dwellings) in real terms

$i_{h} \quad=$ housing investment in real terms

$v \quad=$ inventory stock in real terms

$Y=$ gross domestic product in nominal terms

$t=$ deterministic linear trend 
Table 17 Parameter estimates of the bank credit equations

\begin{tabular}{|c|c|c|c|c|c|c|c|c|c|c|c|c|c|}
\hline & $\mathrm{AU}$ & $\mathrm{BE}$ & $\mathrm{DE}$ & DK & ES & FI & FR & IT & NL & SW & UK & JP & US \\
\hline$L T(\alpha)$ & $\begin{array}{c}-0.02 \\
(3.47)\end{array}$ & $\begin{array}{c}-0.04 \\
(3.81)\end{array}$ & $\begin{array}{c}-0.01 \\
(-)\end{array}$ & $\begin{array}{c}-0.01 \\
(-)\end{array}$ & $\begin{array}{c}-0.01 \\
(-)\end{array}$ & $\begin{array}{c}-0.02 \\
(3.50)\end{array}$ & $\begin{array}{c}-0.01 \\
(-)\end{array}$ & $\begin{array}{c}-0.01 \\
(-)\end{array}$ & $\begin{array}{l}-0.02 \\
(1.81)\end{array}$ & $\begin{array}{c}-0.01 \\
(-)\end{array}$ & $\begin{array}{c}-0.01 \\
(-)\end{array}$ & $\begin{array}{c}-0.01 \\
(-)\end{array}$ & $\begin{array}{c}-0.01 \\
(-)\end{array}$ \\
\hline$\Delta \log C R D_{t-1}$ & $\begin{array}{c}0.08 \\
(1.49)\end{array}$ & $\begin{array}{l}0.019 \\
(0.14)\end{array}$ & $\begin{array}{c}0.14 \\
(2.15)\end{array}$ & $\begin{array}{l}0.003 \\
(0.04)\end{array}$ & & $\begin{array}{c}0.32 \\
(2.99)\end{array}$ & $\begin{array}{l}-0.05 \\
(4.44)\end{array}$ & $\begin{array}{c}0.20 \\
(2.35)\end{array}$ & $\begin{array}{c}0.11 \\
(1.46)\end{array}$ & $\begin{array}{c}0.13 \\
(1.49)\end{array}$ & $\begin{array}{c}0.04 \\
(1.73)\end{array}$ & $\begin{array}{l}-0.15 \\
(1.69)\end{array}$ & $\begin{array}{c}0.25 \\
(2.58)\end{array}$ \\
\hline$\Delta \log C R D_{t-2}$ & $\begin{array}{c}0.05 \\
(1.19)\end{array}$ & $\begin{array}{c}-0.16 \\
(1.50)\end{array}$ & $\begin{array}{c}0.11 \\
(1.49)\end{array}$ & $\begin{array}{c}0.21 \\
(3.07)\end{array}$ & & $\begin{array}{c}0.23 \\
(2.25)\end{array}$ & & $\begin{array}{c}0.14 \\
(1.19)\end{array}$ & $\begin{array}{c}0.10 \\
(1.31)\end{array}$ & $\begin{array}{c}0.40 \\
(3.58)\end{array}$ & & $\begin{array}{c}0.36 \\
(2.96)\end{array}$ & $\begin{array}{c}0.18 \\
(2.06)\end{array}$ \\
\hline$\Delta \log C R D_{t-3}$ & $\begin{array}{c}0.02 \\
(0.30)\end{array}$ & $\begin{array}{l}-0.01 \\
(0.10)\end{array}$ & $\begin{array}{c}0.13 \\
(3.52)\end{array}$ & $\begin{array}{c}0.04 \\
(0.46)\end{array}$ & & $\begin{array}{c}0.01 \\
(0.05)\end{array}$ & & $\begin{array}{c}0.15 \\
(2.07)\end{array}$ & & & & $\begin{array}{c}0.37 \\
(2.92)\end{array}$ & $\begin{array}{c}0.25 \\
(2.68)\end{array}$ \\
\hline$\Delta \log C R D_{t-4}$ & $\begin{array}{c}0.22 \\
(7.03)\end{array}$ & $\begin{array}{c}0.31 \\
(3.17)\end{array}$ & $\begin{array}{c}0.14 \\
(2.21)\end{array}$ & $\begin{array}{c}0.26 \\
(2.75)\end{array}$ & & $\begin{array}{c}0.29 \\
(2.93)\end{array}$ & & & & & & & \\
\hline $\begin{array}{l}\text { weighted interest } \\
\text { rate at } t\end{array}$ & & & $\begin{array}{c}5.13 \\
(2.88)\end{array}$ & & & & & & & & & & \\
\hline $\begin{array}{l}\text { weighted interest } \\
\text { rate at } t-1\end{array}$ & & & $\begin{array}{l}-11.48 \\
(3.63)\end{array}$ & $\begin{array}{r}-10.56 \\
(3.97)\end{array}$ & & & & & & & & & \\
\hline $\begin{array}{l}\text { weighted interest } \\
\text { rate at } t-2\end{array}$ & & & $\begin{array}{c}6.45 \\
(2.93)\end{array}$ & & & & & & & $\begin{array}{l}-2.12 \\
(2.88)\end{array}$ & & & \\
\hline $\begin{array}{l}\text { weighted interest } \\
\text { rate at } t-3\end{array}$ & & & & & & & & & & $\begin{array}{l}-2.01 \\
(2.38)\end{array}$ & & & \\
\hline$\Delta \log p_{y, t}\left(i_{b . t}+i_{h . t}\right)$ & & & & & & & & $\begin{array}{c}0.20 \\
(3.94)\end{array}$ & & & $\begin{array}{c}0.07 \\
(0.89)\end{array}$ & & $\begin{array}{c}0.17 \\
(4.16)\end{array}$ \\
\hline$\Delta \log p_{y, t-1}\left(i_{b, t-1}+i_{h, t-1}\right)$ & & & & $\begin{array}{c}0.17 \\
(3.11)\end{array}$ & & & $\begin{array}{c}0.17 \\
(2.52)\end{array}$ & & & & $\begin{array}{c}0.04 \\
(0.48)\end{array}$ & & \\
\hline$\Delta \log p_{y, t-2}\left(i_{b, t-2}+i_{h, t-2}\right)$ & & & & & & & & & & & $\begin{array}{c}0.13 \\
(1.55)\end{array}$ & & \\
\hline$\Delta \log p_{y, t-3}\left(i_{b, t-3}+i_{h . t-3}\right)$ & & & & & & & & & & $\begin{array}{c}0.10 \\
(2.74)\end{array}$ & $\begin{array}{c}0.10 \\
(1.20)\end{array}$ & & \\
\hline$\Delta \log p_{y, t-4}\left(i_{b, t-4}+i_{h . t-4}\right)$ & & & & & $\begin{array}{c}0.23 \\
(3.70)\end{array}$ & & & & & $\begin{array}{c}0.20 \\
(5.91)\end{array}$ & $\begin{array}{c}0.20 \\
(2.61)\end{array}$ & & \\
\hline $\begin{array}{l}\Delta \log \left(P D I_{t}-O I_{t}\right. \\
\left.+C F_{t}-T_{\text {dirb }, t}\right)\end{array}$ & & $\begin{array}{c}1.39 \\
(2.55)\end{array}$ & & & $\begin{array}{c}0.66 \\
(3.60)\end{array}$ & $\begin{array}{c}0.19 \\
(3.37)\end{array}$ & & & & & & & \\
\hline $\begin{array}{l}\Delta \log \left(P D I_{t-2}-O I_{t-2}\right. \\
\left.+C F_{t-2}-T_{\text {dirb }, t-2}\right)\end{array}$ & & & & & & & & & $\begin{array}{c}0.08 \\
(2.67)\end{array}$ & & & & \\
\hline $\begin{array}{l}\Delta \log \left(P D I_{t-3}-O I_{t-3}\right. \\
\left.+C F_{t-3}-T_{\text {dirb }, t-3}\right)\end{array}$ & & & & & & & $\begin{array}{c}0.27 \\
(2.73)\end{array}$ & & & & & & \\
\hline$\frac{\Delta\left(p_{y, t} v_{t}\right)}{100 Y_{t}}$ & & & & $\begin{array}{c}0.29 \\
(3.00)\end{array}$ & & & & & & & & & \\
\hline$\frac{\Delta\left(p_{y . t-4} v_{t-4}\right)}{100 Y_{t-4}}$ & & & & & & & $\begin{array}{c}0.53 \\
(4.59)\end{array}$ & & & $\begin{array}{c}0.27 \\
(2.25)\end{array}$ & & & \\
\hline$t$ & $\begin{array}{c}-0.0001 \\
(2.25)\end{array}$ & & & & & & & & & $\begin{array}{c}-0.0003 \\
(2.88)\end{array}$ & & & \\
\hline $\bar{R}^{2}$ & 0.90 & 0.53 & 0.80 & 0.71 & 0.70 & 0.75 & 0.84 & 0.69 & 0.81 & 0.55 & 0.92 & 0.82 & 0.75 \\
\hline
\end{tabular}





\section{A.19 Monetary and financial sector: equity prices}

$$
\begin{aligned}
\Delta \log p_{e q, t}= & \alpha\left\{\log p_{e q, t-1}-\log p_{y, t-1}-\beta_{1} l i s_{t-1}-\beta_{2} \log r_{l, t-1}\right\} \\
& +\sum_{i=1}^{3} \gamma_{1, i} \Delta \log p_{e q, t-i}+\sum_{i=0}^{1} \gamma_{2, i} \Delta l i s_{t-i}+\sum_{i=0}^{1} \gamma_{3, i} \Delta \log r_{l, t-i}
\end{aligned}
$$

with

$p_{e q}=$ equity price (index, 1990=100)

$p_{y}=$ price deflator gross domestic product (index, 1990=100)

lis $=$ business labour income share

$r_{l}=$ nominal long-term interest rate (in \%)

\begin{tabular}{|c|c|c|c|c|c|c|c|c|c|c|c|c|c|}
\hline & $\mathrm{AU}$ & $\mathrm{BE}$ & $\mathrm{DE}$ & DK & ES & FI & FR & IT & NL & SW & UK & JP & US \\
\hline$L T(\alpha)$ & $\begin{array}{l}-0.05 \\
(2.28)\end{array}$ & $\begin{array}{c}-0.30 \\
(6.28)\end{array}$ & $\begin{array}{l}-0.07 \\
(2.88)\end{array}$ & $\begin{array}{c}-0.05 \\
(1.72)\end{array}$ & $\begin{array}{l}-0.08 \\
(3.57)\end{array}$ & $\begin{array}{c}-0.06 \\
(3.25)\end{array}$ & $\begin{array}{l}-0.18 \\
(5.15)\end{array}$ & $\begin{array}{c}-0.14 \\
(4.05)\end{array}$ & $\begin{array}{l}-0.03 \\
(1.77)\end{array}$ & $\begin{array}{l}-0.05 \\
(3.04)\end{array}$ & $\begin{array}{l}-0.05 \\
(3.02)\end{array}$ & $\begin{array}{l}-0.06 \\
(2.94)\end{array}$ & $\begin{array}{c}-0.03 \\
(-)\end{array}$ \\
\hline$l i s_{t-1}$ & $\begin{array}{c}-0.54 \\
(5.25)\end{array}$ & $\begin{array}{c}-0.54 \\
(5.25)\end{array}$ & $\begin{array}{c}-0.54 \\
(5.25)\end{array}$ & $\begin{array}{c}-0.54 \\
(5.25)\end{array}$ & $\begin{array}{l}-0.54 \\
(5.25)\end{array}$ & $\begin{array}{c}-0.54 \\
(5.25)\end{array}$ & $\begin{array}{c}-0.54 \\
(5.25)\end{array}$ & $\begin{array}{c}-0.54 \\
(5.25)\end{array}$ & $\begin{array}{l}-0.54 \\
(5.25)\end{array}$ & $\begin{array}{c}-0.54 \\
(5.25)\end{array}$ & $\begin{array}{l}-0.54 \\
(5.25)\end{array}$ & $\begin{array}{c}-0.54 \\
(5.25)\end{array}$ & $\begin{array}{l}-0.54 \\
(5.25)\end{array}$ \\
\hline $\log r_{l, t-1}$ & $\begin{array}{l}-0.08 \\
(9.42)\end{array}$ & $\begin{array}{c}-0.08 \\
(9.42)\end{array}$ & $\begin{array}{l}-0.08 \\
(9.42)\end{array}$ & $\begin{array}{c}-0.08 \\
(9.42)\end{array}$ & $\begin{array}{l}-0.08 \\
(9.42)\end{array}$ & $\begin{array}{c}-0.08 \\
(9.42)\end{array}$ & $\begin{array}{l}-0.08 \\
(9.42)\end{array}$ & $\begin{array}{l}-0.08 \\
(9.42)\end{array}$ & $\begin{array}{l}-0.08 \\
(9.42)\end{array}$ & $\begin{array}{l}-0.08 \\
(9.42)\end{array}$ & $\begin{array}{l}-0.08 \\
(9.42)\end{array}$ & $\begin{array}{l}-0.08 \\
(9.42)\end{array}$ & $\begin{array}{l}-0.08 \\
(9.42)\end{array}$ \\
\hline$\Delta \log p_{e q, t-1}$ & $\begin{array}{c}0.33 \\
(3.91)\end{array}$ & & $\begin{array}{c}0.25 \\
(4.30)\end{array}$ & $\begin{array}{c}0.41 \\
(4.91)\end{array}$ & & & $\begin{array}{c}0.13 \\
(1.84)\end{array}$ & $\begin{array}{c}0.42 \\
(4.66)\end{array}$ & & $\begin{array}{c}0.11 \\
(1.46)\end{array}$ & & $\begin{array}{c}0.22 \\
(2.28)\end{array}$ & \\
\hline$\Delta \log p_{e q, t-2}$ & & & & & $\begin{array}{c}0.21 \\
(3.34)\end{array}$ & $\begin{array}{c}0.13 \\
(1.37)\end{array}$ & $\begin{array}{l}-0.13 \\
(1.97)\end{array}$ & & & & & & \\
\hline$\Delta \log p_{\text {eq, } t-3}$ & & & & & & $\begin{array}{c}0.38 \\
(3.99)\end{array}$ & $\begin{array}{c}0.12 \\
(1.84)\end{array}$ & & & & & & \\
\hline$\Delta l i s_{t}$ & & & $\begin{array}{c}-0.01 \\
(2.26)\end{array}$ & & & & & & $\begin{array}{l}-0.01 \\
(3.67)\end{array}$ & & $\begin{array}{l}-0.01 \\
(2.60)\end{array}$ & & $\begin{array}{l}-0.02 \\
(2.30)\end{array}$ \\
\hline$\Delta l i s_{t-1}$ & & & & & & & & & & $\begin{array}{l}-0.01 \\
(2.47)\end{array}$ & & & \\
\hline$\Delta \log r_{l, t}$ & & & $\begin{array}{l}-0.26 \\
(3.23)\end{array}$ & $\begin{array}{c}-0.29 \\
(2.73)\end{array}$ & $\begin{array}{l}-0.50 \\
(5.16)\end{array}$ & $\begin{array}{c}-0.46 \\
(2.98)\end{array}$ & $\begin{array}{l}-0.37 \\
(3.89)\end{array}$ & $\begin{array}{c}-0.25 \\
(1.51)\end{array}$ & $\begin{array}{l}-0.36 \\
(3.73)\end{array}$ & $\begin{array}{l}-0.44 \\
(3.56)\end{array}$ & $\begin{array}{l}-0.39 \\
(6.11)\end{array}$ & $\begin{array}{c}-0.14 \\
(1.84)\end{array}$ & $\begin{array}{l}-0.17 \\
(3.10)\end{array}$ \\
\hline$\Delta \log r_{l, t-1}$ & & & & $\begin{array}{c}-0.25 \\
(2.10)\end{array}$ & & & & & $\begin{array}{l}-0.24 \\
(2.56)\end{array}$ & & & $\begin{array}{c}-0.19 \\
(2.44)\end{array}$ & $\begin{array}{l}-0.15 \\
(2.76)\end{array}$ \\
\hline $\bar{R}^{2}$ & 0.18 & 0.31 & 0.39 & 0.39 & 0.30 & 0.21 & 0.43 & 0.21 & 0.40 & 0.20 & 0.46 & 0.10 & 0.35 \\
\hline
\end{tabular}

Table 18 Parameter estimates of the equity price equations 


\section{A.20 Monetary and financial sector: housing prices}

$$
\begin{aligned}
\Delta \log \left(p_{h, t} / p_{c, t}\right)= & \alpha\left\{\log \left(p_{h, t-1} / p_{c, t-1}\right)-\beta_{1}\left(\log \left(P D I_{t-1} / p_{c, t-1}\right)-\log \left(k_{h, t-1}\right)\right)\right. \\
& \left.-\beta_{2}\left(r_{l, t-1}-\dot{p}_{c, t-1}\right)-\beta_{3}\left(r_{s, t-1}-\dot{p}_{c, t-1}\right)-\beta_{4} \log \left(p_{i h, t-1} / p_{c, t-1}\right)\right\} \\
& +\sum_{i=1}^{4} \gamma_{1, i} \Delta \log \left(p_{h, t-i} / p_{c, t-i}\right)+\sum_{i=0}^{3} \gamma_{2, i} \Delta\left(r_{l, t-i}\right) \\
& +\sum_{i=0}^{3} \gamma_{3, i} \Delta\left(r_{s, t-i}\right)+\sum_{i=0}^{3} \gamma_{4, i} \Delta \log \left(P D I_{t-i} / p_{c, t-i}\right) \\
& +\gamma_{5} \Delta \log \left(p_{i h, t} / p_{c, t}\right)
\end{aligned}
$$

with

$p_{h} \quad=$ housing price (index, 1990=100)

$p_{c}=$ price deflator private consumption (index, 1990=100)

$P D I=$ personal disposable income

$r_{l}=$ nominal long-term interest rate (in \%)

$r_{s}=$ nominal short-term interest rate (in \%)

$\dot{p}_{c}=$ consumer price inflation (in \%)

$k_{h} \quad=$ real housing stock

$p_{i h}=$ deflator housing investment

remark: $\mathrm{AU}$ is estimated in $\Delta_{4}$-specification 
Table 19 Parameter estimates of the housing price equations

\begin{tabular}{|c|c|c|c|c|c|c|c|c|c|c|c|c|c|}
\hline & $\mathrm{AU}$ & $\mathrm{BE}$ & $\mathrm{DE}$ & DK & ES & FI & FR & IT & NL & SW & UK & JP & US \\
\hline$L T(\alpha)$ & $\begin{array}{l}-0.11 \\
(4.54)\end{array}$ & $\begin{array}{l}-0.09 \\
(3.77)\end{array}$ & $\begin{array}{l}-0.11 \\
(3.44)\end{array}$ & $\begin{array}{l}-0.03 \\
(1.43)\end{array}$ & $\begin{array}{l}-0.04 \\
(2.52)\end{array}$ & $\begin{array}{l}-0.03 \\
(2.03)\end{array}$ & $\begin{array}{l}-0.04 \\
(2.30)\end{array}$ & $\begin{array}{l}-0.04 \\
(2.98)\end{array}$ & $\begin{array}{l}-0.10 \\
(1.58)\end{array}$ & $\begin{array}{l}-0.13 \\
(3.73)\end{array}$ & $\begin{array}{l}-0.05 \\
(4.16)\end{array}$ & $\begin{array}{l}-0.03 \\
(3.92)\end{array}$ & $\begin{array}{l}-0.07 \\
(1.87)\end{array}$ \\
\hline $\begin{array}{l}\frac{1}{4} \sum_{i=1}^{4} \log \left(P D I / p_{c}\right)_{t-i} \\
-\log \left(k_{h, t-4}\right)\end{array}$ & & $\begin{array}{l}1.14 \\
(5.49)\end{array}$ & $\underset{(-)}{0.20}$ & $\underset{(-)}{0.50}$ & & $\begin{array}{l}0.83 \\
(0.92)\end{array}$ & & $\begin{array}{l}0.33 \\
(0.41)\end{array}$ & $\begin{array}{l}1.14 \\
(1.06)\end{array}$ & $\begin{array}{l}0.84 \\
(1.27)\end{array}$ & & & $\begin{array}{l}1.53 \\
(4.98)\end{array}$ \\
\hline $\begin{array}{l}\log \left(P D I / p_{c}\right)_{t-4} \\
-\log \left(k_{h . t-4}\right)\end{array}$ & $\begin{array}{c}1.94 \\
(4.68)\end{array}$ & & & & & & & & & & & & \\
\hline $\begin{array}{l}\frac{1}{4} \sum_{i=1}^{4} \log \left(P D I / p_{c}\right)_{t-i} \\
-\log \left(k_{h, t-2}\right)\end{array}$ & & & & & $\begin{array}{c}0.29 \\
(1.30)\end{array}$ & & $\begin{array}{c}0.34 \\
(1.45)\end{array}$ & & & & & & \\
\hline $\begin{array}{l}\log \left(P D I_{j} p_{c}\right)_{t-1} \\
-\log \left(k_{h, t-2}\right)\end{array}$ & & & & & & & & & & & $\begin{array}{c}0.50 \\
(-)\end{array}$ & $\begin{array}{l}1.12 \\
(1.73)\end{array}$ & \\
\hline$\frac{1}{4} \sum_{i=1}^{4}\left(r_{l, t-i}-\dot{p}_{c, t-i}\right)$ & & $\begin{array}{l}-0.041 \\
(2.25)\end{array}$ & & $\begin{array}{l}-0.028 \\
(2.73)\end{array}$ & & $\begin{array}{l}-0.013 \\
(2.08)\end{array}$ & & $\begin{array}{l}-0.050 \\
(1.17)\end{array}$ & $\begin{array}{l}-0.060 \\
(2.60)\end{array}$ & $\begin{array}{l}-0.038 \\
(3.54)\end{array}$ & & & \\
\hline$\frac{1}{2} \sum_{i=1}^{2}\left(r_{l, t-i}-\dot{p}_{c, t-i}\right)$ & & & & & $\begin{array}{l}-0.012 \\
(0.46)\end{array}$ & & $\begin{array}{l}-0.034 \\
(0.75)\end{array}$ & & & & & & \\
\hline$r_{l, t-1}-\dot{p}_{c, t-1}$ & $\begin{array}{l}-0.052 \\
(1.71)\end{array}$ & & & & & & & & & & & $\begin{array}{l}-0.049 \\
(2.34)\end{array}$ & \\
\hline$r_{l, t-1}-\dot{p}_{c, t-2}$ & & & $\begin{array}{l}-0.028 \\
(2.97)\end{array}$ & & & & & & & & & & \\
\hline$r_{l, t-2}-\dot{p}_{c, t-2}$ & & & & & & & & & & & & & $\begin{array}{l}-0.014 \\
(2.03)\end{array}$ \\
\hline$r_{s, t-1}-\dot{p}_{c, t-1}$ & & & & & & & & & & & $\begin{array}{c}-0.001 \\
(-)\end{array}$ & & \\
\hline$\frac{1}{4} \sum_{i=1}^{4} \log \frac{p_{i h, t-i}}{p_{c . t-i}}$ & & & & & & & & & & & & & $\begin{array}{r}1.47 \\
(2.55)\end{array}$ \\
\hline$\Delta \log \frac{p_{h, t-1}}{p_{c . t-1}}$ & & $\begin{array}{l}-0.27 \\
(2.14)\end{array}$ & $\begin{array}{c}0.19 \\
(3.15)\end{array}$ & $\begin{array}{l}0.24 \\
(1.56)\end{array}$ & $\begin{array}{c}0.65 \\
(8.59)\end{array}$ & $\begin{array}{c}0.37 \\
(4.17)\end{array}$ & $\begin{array}{c}0.36 \\
(3.84)\end{array}$ & $\begin{array}{c}0.41 \\
(4.61)\end{array}$ & & & $\begin{array}{l}0.46 \\
(5.77)\end{array}$ & $\begin{array}{l}0.50 \\
(4.38)\end{array}$ & $\begin{array}{l}0.28 \\
(3.10)\end{array}$ \\
\hline$\Delta \log \frac{p_{h, t-2}}{p_{c . t-2}}$ & & $\begin{array}{l}-0.19 \\
(1.74)\end{array}$ & & & & $\begin{array}{c}0.45 \\
(5.52)\end{array}$ & $\begin{array}{c}0.22 \\
(1.79)\end{array}$ & & & $\begin{array}{l}0.20 \\
(2.34)\end{array}$ & $\begin{array}{l}0.37 \\
(3.96)\end{array}$ & & \\
\hline$\Delta \log \frac{p_{h, t-4}}{p_{c . t-4}}$ & & $\begin{array}{c}0.35 \\
(3.38)\end{array}$ & $\begin{array}{c}0.67 \\
(8.21)\end{array}$ & & & & & $\begin{array}{c}0.46 \\
(3.91)\end{array}$ & $\begin{array}{c}0.32 \\
(3.04)\end{array}$ & $\begin{array}{l}0.63 \\
(5.08)\end{array}$ & & & \\
\hline$\Delta_{4} \log \frac{p_{h, t-1}}{p_{c, t-1}}$ & $\begin{array}{c}0.96 \\
(21.17)\end{array}$ & & & & & & & & & & & & \\
\hline$\frac{1}{4} \sum_{i=0}^{3} \Delta\left(r_{l, t-i}\right)$ & & $\begin{array}{l}-0.005 \\
(0.86)\end{array}$ & & $\begin{array}{l}-0.033 \\
(1.43)\end{array}$ & & $\begin{array}{l}-0.012 \\
(2.08)\end{array}$ & & & $\begin{array}{l}-0.028 \\
(2.40)\end{array}$ & $\begin{array}{l}-0.011 \\
(2.35)\end{array}$ & & & \\
\hline$\frac{1}{2} \sum_{i=0}^{1} \Delta\left(r_{l . t-i}\right)$ & & & & & & & & & & & & & $\begin{array}{l}-0.007 \\
(4.14)\end{array}$ \\
\hline$\frac{1}{4} \sum_{i=0}^{3} \Delta\left(r_{s, t-i}\right)$ & & & & & & & & & & & & $\begin{array}{l}-0.001 \\
(0.73)\end{array}$ & \\
\hline$\Delta\left(r_{s, t-1}\right)$ & & & & & & & & & & & $\begin{array}{l}-0.003 \\
(2.09)\end{array}$ & & \\
\hline$\frac{1}{4} \sum_{i=0}^{3} \Delta \log \frac{P D I_{t-i}}{p_{c, t-i}}$ & & $\begin{array}{c}0.72 \\
(2.64)\end{array}$ & & & $\begin{array}{c}0.29 \\
(1.30)\end{array}$ & & $\begin{array}{l}0.34 \\
(1.45)\end{array}$ & & $\begin{array}{c}0.51 \\
(1.43)\end{array}$ & & $\begin{array}{l}0.21 \\
(0.80)\end{array}$ & $\begin{array}{l}0.31 \\
(2.76)\end{array}$ & $\begin{array}{c}0.11 \\
(0.66)\end{array}$ \\
\hline$\frac{1}{4} \sum_{i=0}^{3} \Delta \log \frac{p_{i h . t-i}}{p_{c, t-i}}$ & & $\begin{array}{l}1.51 \\
(2.02)\end{array}$ & $\begin{array}{c}0.62 \\
(1.88)\end{array}$ & $\begin{array}{c}0.19 \\
(0.43)\end{array}$ & & & & & $\begin{array}{l}1.16 \\
(1.39)\end{array}$ & $\begin{array}{l}1.33 \\
(2.14)\end{array}$ & & & \\
\hline$\Delta \log \frac{p_{\text {ih }, t}}{p_{c . t}}$ & & & & & & $\begin{array}{c}0.10 \\
(2.58)\end{array}$ & & & & & & & $\begin{array}{r}0.54 \\
(3.75)\end{array}$ \\
\hline$\underline{\bar{R}^{2}}$ & 0.96 & 0.75 & 0.61 & 0.38 & 0.74 & 0.67 & 0.26 & 0.66 & 0.65 & 0.75 & 0.71 & 0.85 & 0.45 \\
\hline
\end{tabular}





\section{B A stylised presentation of EUROMON}

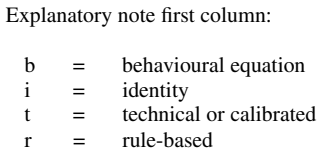

Labour market and physical capital stock

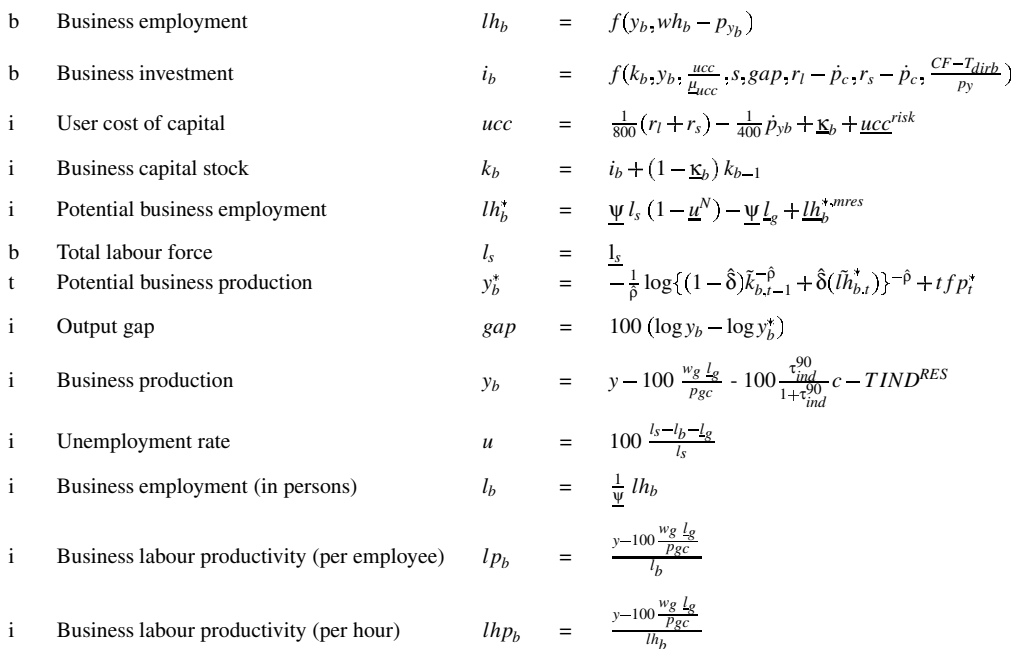

National income

\begin{tabular}{|c|c|c|c|c|}
\hline 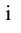 & Gross domestic product & $y$ & $=$ & $c+i_{b}+i_{h}+g_{c}+g_{i}+x-m+\Delta v$ \\
\hline & Private consumption & $c$ & $=$ & $f\left(\frac{P D I}{p_{c}}, \frac{N W_{M V}}{p_{c}}, r_{s}-\dot{p}_{c}, r_{l}-\dot{p}_{c}, \Delta u\right)$ \\
\hline b & Housing investment & $i_{h}$ & $=$ & $f\left(\frac{P D I}{p_{c}}, r_{l}-\dot{p}_{c}\right)$ \\
\hline i & Housing stock & $k_{h}$ & $=$ & $i_{h}+\left(1-\underline{\kappa}_{h}\right) k_{h-1}$ \\
\hline 1 & Government consumption & $g_{c}$ & $=$ & $100 \frac{w_{g} \underline{\underline{l}}}{p_{g c}}+g_{c m}$ \\
\hline & Government consumption, material & $\Delta \log g_{c m}$ & $=$ & $\Delta \log y$ \\
\hline $\mathrm{t}$ & Government investment & $\Delta \log g_{i}$ & $=$ & $\Delta \log y$ \\
\hline i & Change in inventories & $\Delta v$ & $=$ & $y_{t f e}-s$ \\
\hline 1 & Inventory stock & $v$ & $=$ & $v_{-1}+\Delta v$ \\
\hline & Sales & $s$ & $=$ & $c+i_{b}+i_{h}+g_{c}-100 \frac{w_{g} \underline{l}_{g}}{p g c}+g_{i}+x$ \\
\hline & Total final expenditures & $y_{e}$ & $=$ & $f\left(s, v_{-1}, r_{s}-\dot{p}_{c}\right)$ \\
\hline i & Gross domestic product & $Y$ & $=$ & $\frac{1}{100} p_{y} y$ \\
\hline
\end{tabular}




\section{Foreign trade}

$\begin{array}{rllll}\text { i } & \text { Current account balance } & C B & = & \frac{1}{100}\left(p_{x} x-p_{m} m\right)+N X_{P I}+N X_{T R} \\ \text { b } & \text { Exports of goods and services } & x & = & f\left(\frac{p_{x}}{p_{x}^{w}}, m^{w}\right) \\ \text { b } & \text { Imports of goods and services } & m & = & f\left(\frac{p_{m}}{p_{y}}, s, g a p, \frac{\Delta v}{s}\right) \\ \text { b } & \text { Net exports primary income } & N X_{P I} & =f\left(r_{l}^{w}, N F A\right) \\ \text { b } & \text { Net exports transfers } & N X_{T R} & =\text { constant } * Y\end{array}$

\begin{tabular}{|c|c|c|c|c|}
\hline $\mathrm{b}$ & Non-government wage rate (per employee) & $w_{b}$ & $=$ & $f\left(p_{c}, p_{y b}, l p_{b}, \underline{\tau}_{d i r}+\underline{\tau}_{s s c}, u\right)$ \\
\hline $\mathrm{i}$ & Non-government wage rate (per hour) & $w_{h b}$ & $=$ & $\frac{1}{\Psi} w_{b}$ \\
\hline $\mathrm{t}$ & Government wage rate (per employee) & $\Delta \log w_{g}$ & $=$ & $\Delta \log w_{b}$ \\
\hline $\mathrm{i}$ & Unit labour costs & $u l c$ & $=$ & $\frac{w_{b} l_{b}}{y-100 \frac{w_{g} \underline{L}_{g}}{p g c}}$ \\
\hline $\mathrm{i}$ & Business labour income share & lis & $=$ & $100 \frac{w_{b} l_{b}}{Y-w_{g} l_{g}-T_{\text {ind }}}$ \\
\hline $\mathrm{b}$ & Price deflator private consumption & $p_{c}$ & $=$ & $f\left(u l c, p_{m}, \underline{\tau}_{\text {ind }}, g a p\right)$ \\
\hline $\mathrm{t}$ & Price deflator government consumption & $\Delta \log p_{g c}$ & $=$ & $0.5 \Delta \log p_{g c-1}+0.5 \Delta \log p_{c}$ \\
\hline $\mathrm{t}$ & Price deflator government investment & $\Delta \log p_{g i}$ & $=$ & $0.5 \Delta \log p_{g i-1}+0.5 \Delta \log p_{c}$ \\
\hline $\mathrm{t}$ & Price deflator residential investment & $p_{i h}$ & $=$ & $f\left(p_{c}\right)$ \\
\hline $\mathrm{b}$ & Price deflator exports of goods and services & $p_{x}$ & $=$ & $f\left(p_{x}^{w}, p_{y}\right)$ \\
\hline $\mathrm{b}$ & Price deflator imports of goods and services & $p_{m}$ & $=$ & $f\left(p_{m}^{w}, \underline{p}_{o i l}, \underline{p}_{c o m}, e_{D O L}, p_{y b}\right)$ \\
\hline $\mathrm{t}$ & Price deflator gross domestic product & $\Delta \log p_{y}$ & $=$ & $0.5 \Delta \log p_{y-1}+0.5 \Delta \log p_{c}$ \\
\hline $\mathrm{i}$ & Price deflator business production & $\Delta \log p_{y_{b}}$ & $=$ & $\Delta \log p_{c}-\Delta \log \left(1+\tau_{\text {ind }}\right)$ \\
\hline $\mathrm{i}$ & Inflation & $\dot{p}_{c}$ & $=$ & $100 \Delta_{4} \log p_{c}$ \\
\hline
\end{tabular}

Public sector

\begin{tabular}{|c|c|c|c|c|}
\hline i & Gross financial balance & $G F B$ & $=$ & $\begin{array}{l}T_{d i r}+T_{\text {ind }}+T_{s s c}-\frac{1}{400}\left\{\left(1-\underline{\vartheta}_{D P S}\right) r_{s}+\underline{\vartheta}_{D P S} r_{l}\right\} D_{-1} \\
G_{c}-G_{i}-T R-O G E+\underline{G F B}^{\text {mres }}\end{array}$ \\
\hline i & Government debt & $\Delta D$ & $=$ & $-G F B+\underline{D}^{m r e s}$ \\
\hline i & Direct taxes & $T_{\text {dir }}$ & $=$ & $T_{\text {dirp }}+T_{\text {dirb }}+\underline{T}_{\text {dir }}^{\text {mres }}$ \\
\hline i & Direct taxes on personal income & $T_{\text {dirp }}$ & $=$ & $\underline{\tau}_{\text {dirp }}\left(C O M+O I+T R-T_{s s c}\right)+\underline{T}_{\text {dirp }}^{\text {mres }}$ \\
\hline $\mathrm{i}$ & Corporate taxes & $T_{\text {dirb }}$ & $=$ & $\underline{\tau}_{d i r b}\{C F-\underline{D E P}$ \\
\hline & & & - & $\left.\frac{1}{400}\left(\underline{\vartheta}_{C R D B} r_{l}+\left(1-\underline{\vartheta}_{C R D B}\right) r_{s}\right) \underline{\omega}_{C R D B} C R D\right\}+\underline{T}_{\text {dirb }}^{\text {mres }}$ \\
\hline $\mathrm{i}$ & Indirect taxes & $T_{\text {ind }}$ & $=$ & $\underline{\tau}_{\text {ind }} p_{c} c+\underline{T}_{\text {ind }}^{\text {mres }}$ \\
\hline i & Social security contributions & $T_{s s c}$ & $=$ & $\underline{\tau}_{s s c}(C O M+T R)+\underline{T}_{s s c}^{m r e s}$ \\
\hline $\mathrm{i}$ & Government consumption & $G_{c}$ & $=$ & $\frac{1}{100} p_{g c} g_{c}$ \\
\hline i & Government investment & $G_{i}$ & $=$ & $\frac{1}{100} p_{g i} g_{i}$ \\
\hline D & Transfers & $\frac{T R}{Y}$ & $=$ & $f\left(u, \frac{w_{g}}{p_{y}}, \frac{p_{c}}{p_{y}}\right)$ \\
\hline$b$ & Net other government expenditures & $O G E$ & $=$ & constant $* Y$ \\
\hline
\end{tabular}




$\begin{array}{ll}\text { i } & \text { Net financial wealth private sector } \\ \text { i } & \text { Net wealth private sector at market value } \\ \text { i } & \text { Market value domestic equity } \\ \text { b } & \text { Broad money } \\ \text { i } & \text { Private sector holdings of non-government bonds } \\ \text { i } & \text { Private sector holdings of government debt } \\ \text { i } & \text { Net foreign assets owned by the private sector } \\ \text { i } & \text { Total private sector financial assets } \\ \text { b } & \text { Bank credit to private sector } \\ \text { i } & \text { Personal disposable income } \\ \text { i } & \text { Total wage compensation } \\ \text { t } & \text { Other household income }\end{array}$

i Cash flow

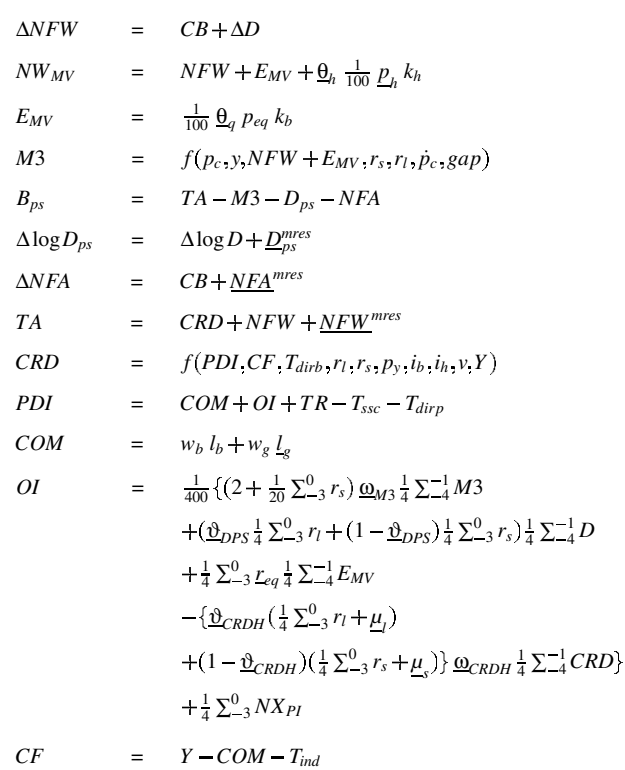

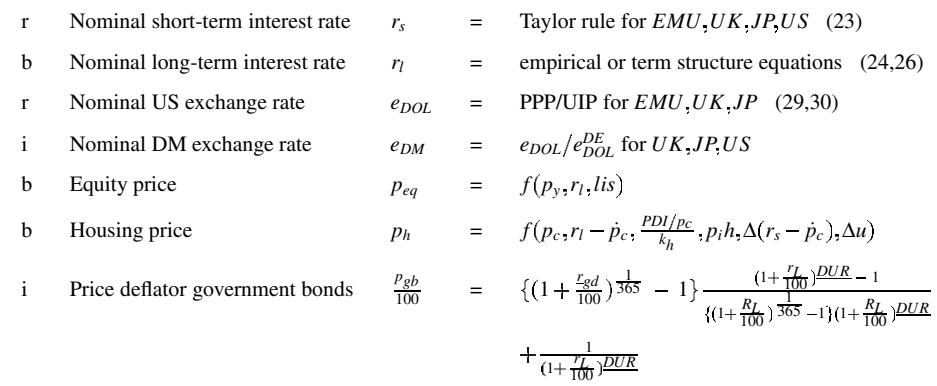




\section{Weighted variables}

i Relevant world trade $\quad \frac{\Delta m^{w}}{m^{w}}=\sum_{j=1}^{13} \frac{e w_{j}}{m_{j,-1}}$

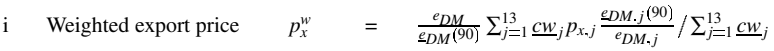

$\mathrm{i} \quad$ Weighted import price $\quad p_{m}^{w}=\frac{e_{D M}}{\underline{e}_{D M}(90)} \sum_{j=1}^{13} \underline{i w}_{j} p_{x, j} \frac{\underline{e}_{D M, j}(90)}{e_{D M . j}}$

i Effective exchange rate $e_{f e x}=100 \frac{\frac{e}{D M}(90)}{{ }^{e} D M} \sum_{j=1}^{13} \frac{c w_{j}}{\underline{e}_{D D M . j}{ }^{e}{ }_{D M}(90)} / \sum_{j=1}^{13} \frac{c w}{j}$

\section{Additional}

i Current balance ratio

$$
\begin{array}{ll}
C B Y & =100 \frac{C B}{Y} \\
D Y & =100 \frac{D}{\sum_{-3}^{0} Y}
\end{array}
$$

i Government debt ratio

i Government financial balance ratio

$$
G F B Y=100 \frac{\Sigma_{-3}^{0} G F B}{\Sigma_{-3}^{0} Y}
$$

World variables

\begin{tabular}{|c|c|c|c|}
\hline Broad money eurozone & $M 3^{E M U}$ & $=$ & $\sum_{j=1}^{13} \frac{M 3_{j}}{\underline{e}_{D M, j}(90)}\left(I_{\{j=A U, B E, F I, N L\}}+1000 I_{\{j=D E . E S . F R . I T\}}\right)$ \\
\hline Inflation eurozone & $\dot{p}_{c}^{E M U}$ & $=$ & $\sum_{j=1}^{13} \dot{p}_{c . j} \underline{\zeta}_{y E M U}\left(I_{\{j=A U . B E, F I, N L\}}+1000 I_{\{j=D E, E S, F R, I T\}}\right)$ \\
\hline Gross domestic product eurozone & $Y^{E M U}$ & $=$ & $\sum_{j=1}^{13} \frac{Y_{j}}{\underline{e}_{D M, j}(90)}\left(I_{\{j=A U, B E, F I, N L\}}+1000 I_{\{j=D E . E S . F R . I T\}}\right)$ \\
\hline Output gap eurozone & $g a p^{E M U}$ & 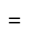 & $\sum_{j=1}^{13} \operatorname{gap}_{j} \underline{\zeta}_{y E M U}\left(I_{\{j=A U . B E, F I, N L\}}+1000 I_{\{j=D E, E S, F R, I T}\right.$ \\
\hline
\end{tabular}

$\mathrm{i}$ World nominal long-term interest rate $r_{l}^{w}=\sum_{j=1}^{13} r_{l, j} \underline{\zeta}_{y w}\left(I_{\{j \neq D E . E S . F R, I T, J P\}}+1000 I_{\{j=D E . E S . F R . I T . J P\}}\right)$

Eurozone variables 
Publications in this series as from January 2003

Vol. I/Nr. I (2003) Requirements for successful currency regimes:

The Dutch and Thai experiences

Robert-Paul Berben, Jan Marc Berk, Ekniti Nitihanprapas, Kanit Sangsuphan, Pisit Puapan and Piyaporn Sodsriwiboon

Vol. I/Nr. 2 (2003) The blurring of distinctions between financial sectors: fact or fiction?

Annemarie van der Zwet

Vol. I/Nr. 3 (2003) Intermediation, integration and internationalisation: a survey on banking in Europe Jaap Bikker and Sandra Wesseling

Vol. I/Nr. 4 (2003) A Survey of Institutional Frameworks for Financial Stability Sander Oosterloo and Jakob de Haan

Vol. 2/Nr. I (2004) Towards a framework for financial stability Aerdt Houben, Jan Kakes and Garry Schinasi

Vol. 2/Nr. 2 (2004) Depositor and investor protection in the Netherlands: past, present and future Gillian Garcia and Henriëtte Prast

Vol. 3/Nr. I (2005) Labour market participation of ageing workers: Micro-financial incentives and policy considerations W. Allard Bruinshoofd en Sybille G. Grob

Vol. 3/Nr. 2 (2005) Payments are no free lunch Hans Brits and Carlo Winder

Vol. 4/Nr. I (2006) EURomon: the multi-country model of De Nederlandsche Bank Maria Demertzis, Peter van Els, Sybille Grob and Marga Peeters 
